
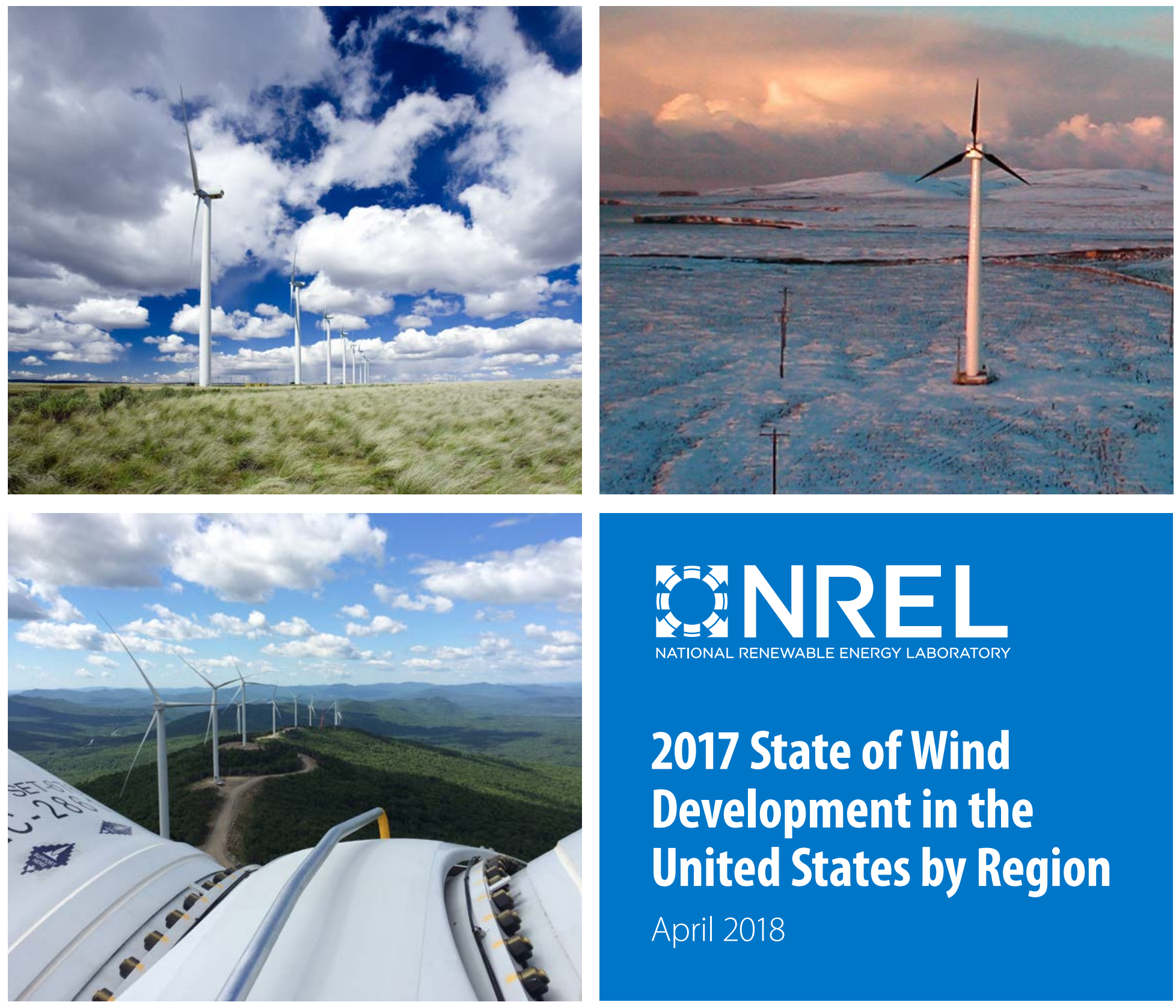

April 2018
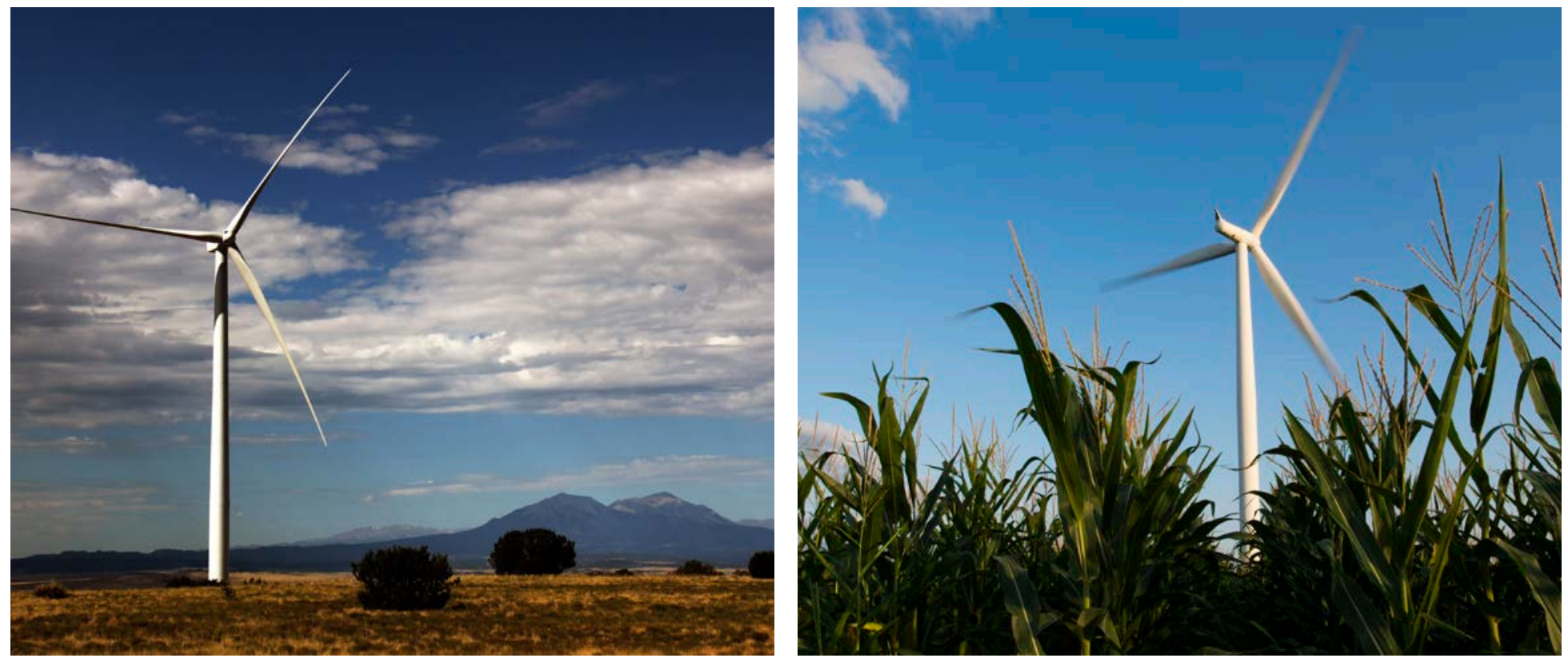

NREL is a national laboratory of the U.S. Department of Energy, Office of Energy Efficiency and Renewable Energy, operated by the Alliance for Sustainable Energy, LLC. 


\section{State of Wind Development in the United States by Region}

Frank Oteri, Ruth Baranowski, Ian Baring-Gould, and Suzanne Tegen National Renewable Energy Laboratory

\section{Suggested Citation}

Oteri, Frank, Ruth Baranowski, lan Baring-Gould, and Suzanne Tegen. 2018. 2017 State of Wind Development in the United States by Region. Golden, CO: National Renewable Energy Laboratory. NREL/ TP-5000-70738. https://www.nrel.gov/docs/fy180sti/70738.pdf.

NREL is a national laboratory of the U.S. Department of Energy Office of Energy Efficiency \& Renewable Energy Operated by the Alliance for Sustainable Energy, LLC

This report is available at no cost from the National Renewable Energy Laboratory (NREL) at www.nrel.gov/publications.

\section{Technical Report}

NREL/TP-5000-70738

April 2018

Contract No. DE-AC36-08GO28308
National Renewable Energy Laboratory 15013 Denver West Parkway

Golden, CO 80401

303-275-3000 • www.nrel.gov 


\section{NOTICE}

This manuscript has been authored by employees of the Alliance for Sustainable Energy, LLC ("Alliance") under Contract No. DE-AC36-08GO28308 with the U.S. Department of Energy ("DOE”).

This report was prepared as an account of work sponsored by an agency of the United States government. Neither the United States government nor any agency thereof, nor any of their employees, makes any warranty, express or implied, or assumes any legal liability or responsibility for the accuracy, completeness, or usefulness of any information, apparatus, product, or process disclosed, or represents that its use would not infringe privately owned rights. Reference herein to any specific commercial product, process, or service by trade name, trademark, manufacturer, or otherwise does not necessarily constitute or imply its endorsement, recommendation, or favoring by the United States government or any agency thereof. The views and opinions of authors expressed herein do not necessarily state or reflect those of the United States government or any agency thereof. 


\section{Acknowledgments}

The authors thank the U.S. Department of Energy (DOE) Wind Energy Technologies Office for funding the Regional Resource Centers, this report, and broader stakeholder engagement and education efforts such as the WINDExchange initiative. The authors also thank DOE’s Jocelyn Brown-Saracino, Maggie Yancey, Lillie Ghobrial, and Liz Hartman for their leadership and guidance.

Thanks to the Regional Resource Centers for their work and contributions to this document:

- Four Corners Wind Resource Center: Amanda Ormond, Sarah Propst, Sarah Wright, Karin Wadsack, Mitalee Gupta, Fletcher Wilkinson

- Islanded Grid Resource Center: Suzanne MacDonald, Stephanie Nowers, Chris Rose, Brooks Winner

- Midwest Wind Energy Center: Lisa Daniels, Dan Turner, Tom Wind

- Northeast Wind Resource Center: Deborah Donovan, Benjamin Brown, Bob Patton, Jake McDermott, Diana Chace, Warren Leon, Val Stori

- Northwest Wind Resource and Action Center: Diane Broad, Mia Devine, Michael O’Brien, Rachel Shimshak, David Wolf, Cameron Yourkowski

- Southeast Wind Energy Resource Center: Paul Gayes, Mary Hallisey Hunt, Stephen Kalland, Katharine Kollins, Jonathan Miles.

Thanks to Brian Smith and Daniel Laird from the National Renewable Energy Laboratory for their review of this report. Also thanks to Corrie Christol and Bethany Straw who work to support our regional stakeholder engagement projects. 


\section{List of Abbreviations and Acronyms}

$\begin{array}{ll}\text { 4CWRC } & \text { Four Corners Wind Resource Center } \\ \text { BLM } & \text { Bureau of Land Management } \\ \text { BOEM } & \text { Bureau of Ocean Energy Management } \\ \text { BPA } & \text { Bonneville Power Administration } \\ \text { CAISO } & \text { California Independent System Operator } \\ \text { CNMI } & \text { Commonwealth of the Northern Mariana Islands } \\ \text { DOE } & \text { U.S. Department of Energy } \\ \text { EIM } & \text { energy imbalance market } \\ \text { ETI } & \text { Energy Transition Initiative } \\ \text { GCAMP } & \text { Georgia Coastal and Marine Planner } \\ \text { IGRC } & \text { Islanded Grid Resource Center } \\ \text { IRP } & \text { integrated resource plan } \\ \text { JEDI } & \text { Jobs and Economic Development Impacts } \\ \text { JMU } & \text { James Madison University } \\ \text { kW } & \text { kilowatt } \\ \text { kWh } & \text { kilowatt-hour } \\ \text { MW } & \text { Negawatt } \\ \text { MISO } & \text { Midcontinent Independent System Operator } \\ \text { MWEC } & \text { Nidwest Wind Energy Center } \\ \text { NAWEA } & \text { North American Wind Energy Academy } \\ \text { NREL } & \text { NWRC }\end{array}$




$\begin{array}{ll}\text { PURPA } & \text { Public Utility Regulatory Policies Act } \\ \text { REopt } & \text { Renewable Energy Planning and Optimization } \\ \text { RFP } & \text { request for proposals } \\ \text { RPS } & \text { renewable portfolio standard } \\ \text { RRC } & \text { Regional Resource Center } \\ \text { SWERC } & \text { Southeast Wind Energy Resource Center } \\ \text { USFWS } & \text { U.S. Fish and Wildlife Service }\end{array}$

iii 


\section{Executive Summary}

Although the wind capacity installed by the end of 2016 is estimated, in an average year, to equate to $6.4 \%$ of electricity demand in the United States, wind energy has the potential to meet even more of our country's demand for energy (U.S. Department of Energy 2017c). In 2016, the industry took a major step forward with the commissioning of the nation's first offshore project, the 30-MW Block Island project in Rhode Island. Another exciting development in 2017 was wind energy becoming the largest source of renewable electric capacity in the United States (and the fourth largest overall) (American Wind Energy Association 2018). Additionally, corporate and other non-utility purchases of wind energy continue to influence expansion across the country. With more than 1,500 megawatts of power purchase agreements signed in 2016 and multiple new agreements signed in 2017 by companies such as Kimberly-Clark, Google, General Motors, Anheuser-Busch, Cummins, and JP Morgan Chase, this growing market enhances the long-term installation prospects for the wind industry moving forward. Despite this growth, continued expansion of wind energy development will be required to achieve the scenarios outlined in the U.S.

Department of Energy's (DOE)'s Wind Vision: 20\% wind energy by 2030 and 35\% wind energy by 2050 .

Researchers at DOE's national laboratories have conducted analyses and determined that innovation in wind technology can have consequential implications for future wind power development throughout the United States, and it can impact the broader electricity system, lower electric system and consumer costs, provide potential environmental benefits, and expand the U.S. wind workforce (Mai et al. 2017). The wind industry and the DOE's Wind Energy Technologies Office are addressing technical wind energy challenges, such as reducing turbine costs and increasing energy production and reliability. Turbine nameplate capacity, hub height, and rotor diameter have increased significantly. Turbines originally designed for lower wind speed sites have rapidly gained market share, and pending and proposed projects are continuing the trend of even-taller turbines as lower wind sites appear to be targeted (U.S. Department of Energy 2017c). This turbine scaling is significantly boosting wind project performance, contributing to low power sales prices. Wind power sales prices are at all-time lows, enabling economic competitiveness despite low natural gas prices. Analysts project that annual wind power capacity additions will continue for the next several years before declining, driven by the 5-year extension of the Production Tax Credit signed in December 2015 and the progressive reduction in the value of the credit over time (U.S. Department of Energy 2017c). Demand drivers also include corporate wind energy purchases and state-level renewable energy policies. At the same time, expectations for continued low natural gas prices, modest electricity demand growth, and lower nearterm demand from state RPS policies put a damper on growth expectations, as do inadequate transmission infrastructure and competition from solar energy in certain regions of the country. Yet the potential for continued technological advancements and cost reductions enhance the prospects for longer-term growth, as does burgeoning corporate demand for wind energy and continued state RPS requirements. Given these diverse underlying potential trends, wind capacity additions - especially after 2020-remain deeply uncertain (U.S. Department of Energy 2017c). 
Beyond these market trends, the Office also recognizes that human-use conflicts with wind energy can be challenging, depending on the proximity of proposed wind farms to local populations. As wind development expands, more information is becoming available on the local community impacts of wind deployment. However, the public and local decisionmakers often cite a lack of scientifically credible information as an issue. In some cases, this information is available but not readily accessible; in others, the information is not conclusive. Where information does exist, it should be made readily available to the public in a user-friendly format. Continued and increased engagement at multiple levels will be needed given the expanding nature of the industry. In 2014, DOE established six Regional Resource Centers (RRCs) across the United States to communicate unbiased, credible information about wind energy development to stakeholders through regional networks. The RRCs serve as a platform to localize the information important to the regions they cover, provide information about potential benefits and issues in wind development, and disseminate data on wind development siting considerations such as turbine sound and wildlife habitat protection community considerations.

Each U.S. region experiences unique wind energy development challenges due to many factors: availability of wind resources and other natural resources, population density, community needs, and permitting processes resulting from the presence of local wildlife species. Continued growth of U.S. wind energy would require high-impact, regionalspecific strategies that provide region-specific, unbiased information to inform communities making policy and permitting decisions on processes and improve public discourse, seeking to reduce human-use conflict around development decisions and ensuring that wind development is responsible and responsive to the American public's needs. As a starting point to developing strategies, WINDExchange requested that the RRC representatives identify market challenges in their regions that have affected wind energy development. These issues include:

- Insufficient transmission capacity and the need for transmission improvements

- Power market conditions that limit wind development (such as small balancing areas and hour-ahead dispatching)

- Lack of local wind siting or zoning ordinances; ordinances that do not reflect best practices or do not allow the flexibility in wind development to address small, distributed, community, or utility-scale wind projects

- Grid interconnection and integration challenges and costs

- Lack of clear federal policy covering wind power-related initiatives and awareness of those policies

- Minimal past public education and engagement on wind siting issues, exacerbated by inaccurate information and negative public opinion regarding wind energy

- Lack of understanding about wind energy's economic impacts, including local tax benefits, jobs and economic development, and turbine manufacturing

- Challenges with development on federal and native lands

- Accurate wind information not being utilized in utility integrated resource and statebased clean energy planning

- Restricted access to capital; limited financing, funding, and technical assistance for small, community, and distributed wind development. 
The RRCs also identified the following issues as unique to offshore wind energy development:

- The current high costs of offshore wind energy and lack of articulated benefits describing how initial high costs for early projects can lead to reduced costs for future projects

- Minimal independent information and outreach geared toward innovative regional procurement targets, limiting the ability of projects to attract financing, investigate alternative financing mechanisms, and initiate regional supply chain development

- The fact that there are few full-scale offshore wind turbines currently deployed in the United States and therefore limited U.S.-based research about actual offshore wind development. This limited research results in inadequate information regarding the offshore wind regulatory process; technical issues related to installation, interconnection, and operation; environmental and human use impacts; and acceptance of offshore wind

- Lack of clear understanding of the regional and national market opportunity for offshore wind development.

The RRCs also identified distinct challenges unique to wind development in isolated, islanded power systems found primarily in Alaska, coastal New England, Hawaii, the Territories of the United States, and international locations. The primary development challenges include:

- The high up-front cost of deploying sophisticated wind technologies and associated hardware in an isolated, remote, or islanded area with relatively low technical and human capacity

- Excessive transportation and mobilization costs, much higher than costs for communities in other regions on the road system

- Limited ability to gain economies of scale due to the relatively small project size

- Lack of experience and extra costs of integrating wind into smaller, less flexible electric grids

- Lack of clear regulatory policy and examples that define the rules of engagement between small utilities and independent power producers that wish to develop wind energy supplied to small, typically municipal utilities

- Specific challenges relating to expanded wind integration into the Railbelt transmission system ${ }^{1}$ in Alaska (Baranowski et al. 2017).

This document summarizes the status and drivers for U.S. wind energy development in 2017. RRC leaders provided a report of wind energy development in their regions, which was combined with findings from National Renewable Energy Laboratory (NREL) researchers to provide an account of the state of the regions, as well as updates on developments in individual states. NREL researchers and state partners added updates for all states that are not directly supported by an RRC. Accounts for each region include updates on renewable portfolio standards, workforce development, manufacturing and

\footnotetext{
${ }^{1}$ A small, isolated transmission system in Alaska that covers the state's population centers along the main railroad line, including the Seward, the Kenai, Anchorage, Wasilla, and north to Fairbanks.
} 
economic development, and individual state updates for installed wind capacity, ongoing policy developments, planned projects and their status, transmission progress reports, etc.

This report also highlights the efforts of the RRCs to engage stakeholders in their individual regions. The RRCs and the regions they serve are (in alphabetical order):

- Four Corners Wind Resource Center, serving Arizona, Colorado, New Mexico, Utah, Nevada, and part of Wyoming

- Islanded Grid Resource Center, serving Alaska, Maine, Massachusetts, Rhode Island, Hawaii, Guam, American Samoa, Commonwealth of Northern Marianas, and U.S. Virgin Islands

- Midwest Wind Energy Center, serving eastern Montana and Illinois, Indiana, Iowa, Michigan, Minnesota, Missouri, North Dakota, Ohio, South Dakota, and Wisconsin

- Northeast Wind Resource Center, serving New England (Connecticut, Maine, Massachusetts, New Hampshire, Rhode Island, and Vermont) and New York for land-based wind, and that same region plus New Jersey for offshore wind

- Northwest Wind Resource and Action Center, serving Washington, Oregon, Idaho, western Montana, and part of Wyoming

- Southeast Wind Energy Resource Center, serving North Carolina, Florida, Louisiana, South Carolina, Georgia, Alabama, Mississippi, Virginia, Kentucky, Tennessee, and Arkansas.

On the national level, DOE's WINDExchange ${ }^{2}$ initiative (managed by NREL) provides additional information to the RRCs and supports states not covered by one of these regional organizations.

In the second year of this initiative, the RRCs reported that they provided more than 95,000 key stakeholders with unbiased information about wind power. The RRCs also reported that more than 68,700 people or organizations were directly engaged by the RRCs, meaning that they entered a two-way conversation about wind energy or progressed to a point of accepting wind energy as an option to address the nation's long-term energy needs. Engagements were typically made through events such as meetings with identified stakeholders, interactive webinars, workshops, tours, and presentations at regional conferences. Additional efforts were undertaken through outreach products such as handouts, meeting materials, and newsletters, while direct engagement with regional media organizations was also supported. More than 3.5 million people have been reached by RRC outreach efforts. More targeted efforts ensured that key stakeholders received information that allowed them to include wind technology in plans or policies that had either not included wind or that included outdated wind information.

Many notable RRC projects that may help support expanded wind development are underway. Examples include:

2 https://windexchange.energy.gov/ 
- In 2017, Utah counties published the first locally written resource management plans (RMPs), defining county priorities for the development and use of federal lands. With more than half of Utah's land under the jurisdiction of federal land management agencies, federal agencies and state and county governments find these RMPs indispensable in planning and integrating the goals and policies of local jurisdictions when establishing new rules. As part of this effort, the Four Corners Wind Resource Center (4CWRC) worked with Utah county officials for more than a year to ensure that local stakeholders have the information they need to address wind energy development within the scope of their RMPs. The 4CWRC provided background on wind energy and guidance language regarding wind resources, technology advancements, and development that all of Utah's 29 counties, as well as seven multi-county associations and the Utah Association of Counties, could use to ensure that those unfamiliar with wind energy would have current information and appropriate language to meet Utah's renewable energy target.

- In March 2017, residents and energy leaders from Monhegan, Maine, and Nantucket and Martha's Vineyard, Massachusetts, traveled to Block Island with the Islanded Grid Resource Center and representatives from the University of Maine's Aqua Ventus project to meet with local stakeholders and expand an ongoing dialogue among all four communities. In addition to discussions that covered aspects of offshore development, the March 2017 IGRC effort featured a multiperspective exploration of the Block Island Wind Farm. This allowed participants to observe the turbines from the shore to understand land-based visual impacts before boarding a maintenance vessel to get an up-close view of the project, an opportunity to experience an offshore wind farm prior to the installation of proposed projects that will impact residents back home. Participants also met with the local tourism council to learn about the project's impacts to tourism on the island.

- A Midwest Wind Energy Center principal provided testimony to the Iowa Utility Board supporting Interstate Power and Light Company's proposal to expand its wind generation near the town of Hampton by $500 \mathrm{MW}$. This testimony helped lead to the project's approval, and construction is slated to begin in spring 2018.

- Through the Northeast Wind Resource Center, the Clean Energy Group and its sister organization the Clean Energy States Alliance have worked with state agencies in the region on mechanisms for reducing offshore wind barriers and developing a domestic offshore wind market. In early 2015, the Clean Energy Group, Clean Energy States Alliance, and stakeholders from various Northeast states discussed the potential for cooperative action to develop offshore wind at scale to reduce costs. The Massachusetts Clean Energy Center, the Massachusetts Department of Energy Resources, the Rhode Island Office of Energy Resources, and the New York State Energy Research Development Authority agreed to collaborate to develop a roadmap for speeding offshore wind development and reducing the cost of that development. Three reports published in November 2017 are a result of this effort. 
- With contributions from Northwest Wind Resource and Action Center and a multitude of RRC partners, the Oregon Department of Energy released a new report that outlines the necessary steps to foster the development of offshore wind in the Pacific Northwest. Published in May 2017, Offshore Wind in the Pacific Northwest: Strategy Recommendations ${ }^{3}$ examines the current state of offshore wind in terms of technology, regulatory practices, resource potential, and existing infrastructure.

- In 2017, the Southeastern Wind Coalition organized and led North Carolina state legislators on two tours of the Amazon Wind Farm U.S. East, the first wind energy project in the state. The tours of the site near Elizabeth City, North Carolina, were meant to educate stakeholders about the project's economic benefits and potential impacts, including those to military operations as there is a Navy radar system in the region.

In states not represented by an RRC, significant developments include:

- In 2017, Texas produced more wind power in a given amount of time than ever in history. The state reached "peak wind” at 3:50 a.m. on March 23, when local wind farms produced $50 \%$ of the total electricity load of the state's main power grid (ERCOT 2017). On March 31, wind electricity generation in Texas hit a new wind output record of 16,141 MW, representing approximately 39.5\% of total electric demand (S\&P Global Platts 2017).

- In December 2016, the 60-mile Elm Creek to Summit Project went online in Kansas, providing increased reliability and new wind transmission capacity between Salina and Concordia. Additionally, the proposed Grain Belt Express Clean Line will impact the ability to transmit Kansas wind energy outside of the state. If approved, the 780-mile project will deliver 4,000 MW of wind energy from the western portion of the state to Missouri, Indiana, Illinois, and other neighboring states. Both projects help to address a significant barrier to wind development in the state: a lack of transmission to deliver clean energy from wind-rich areas to the demand.

- The Maryland Public Service Commission approved two proposals for offshore wind farms off the coast of Ocean City because of economic benefit to the state: approximately 9,700 jobs and \$1.8 billion of in-state spending over 20 years. The Public Service Commission required project developers U.S. Wind and Deepwater Wind to build part of their supply chains in Maryland, to spend at least $\$ 76$ million on steel manufacturing in Maryland, and to use ports in the state. The developers are also required to invest $\$ 40$ million into Tradepoint Atlantic, a shipyard near Baltimore that was once home to Bethlehem Steel.

${ }^{3}$ http://nwwindcenter.org/sites/default/files/Offshore_Wind_Strategy_Paper_FINAL_May2017.pdf 
According to the American Wind Energy Association, as of the end of 2017, almost 29,000 MW of wind capacity are under construction or in advanced development (American Wind Energy Association 2018). In 2017, U.S. regions experienced many wind energy successes, but many challenges remain along with unanswered questions about what's next for technology development and the opportunity for wind to be a viable energy resource responsibly harnessed across the country. 


\section{Table of Contents}

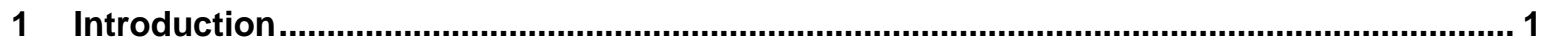

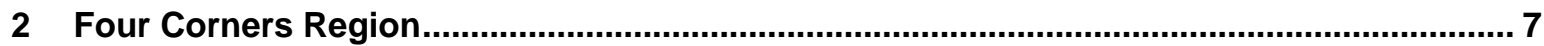

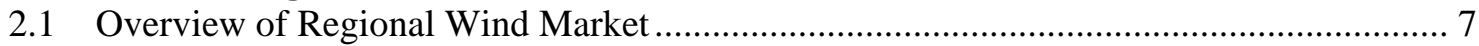

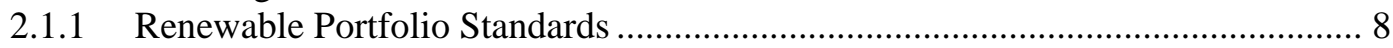

2.1.2 Communities with 100\% Renewable Energy Commitments ................................ 9

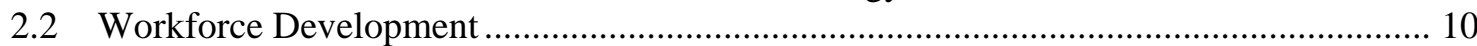

2.2.1 North American Wind Energy Academy ..................................................... 11

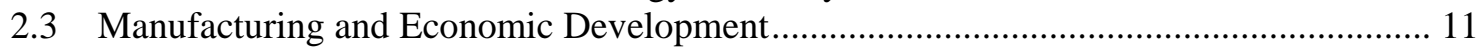

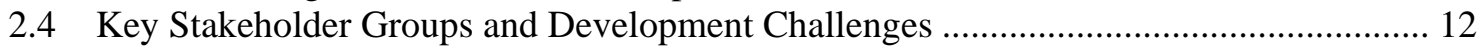

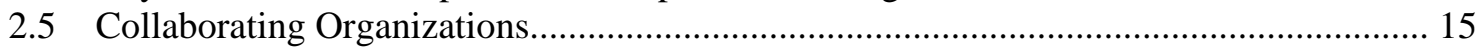

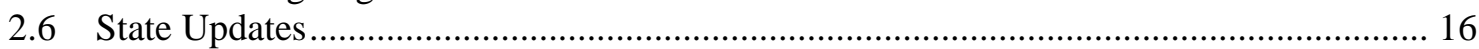

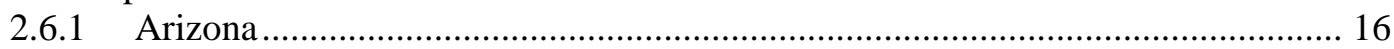

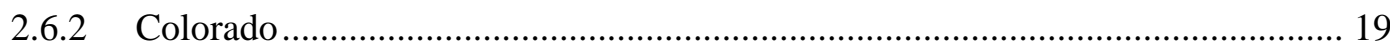

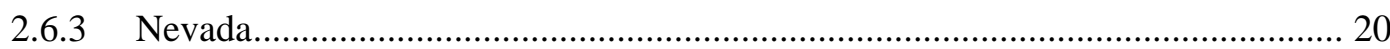

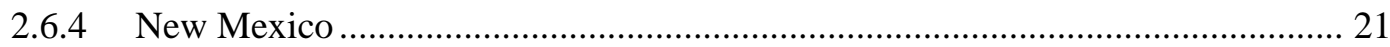

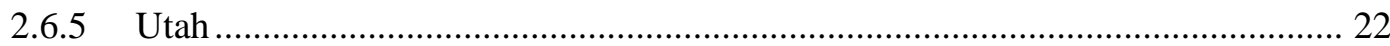

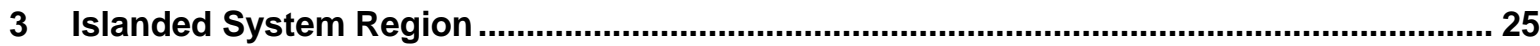

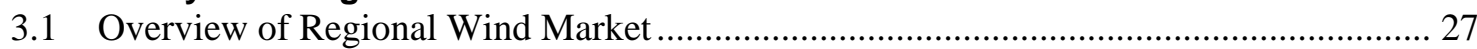

3.1.1 Renewable Portfolio Standards ......................................................................... 27

3.1.2 Communities with 100\% Renewable Energy Commitments .............................. 28

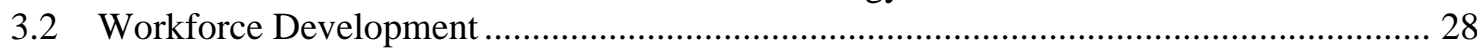

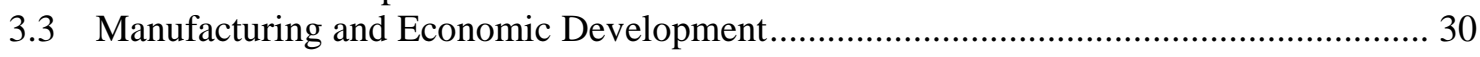

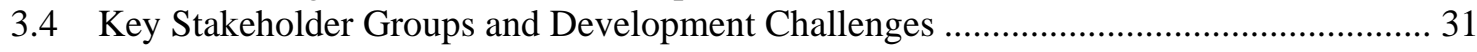

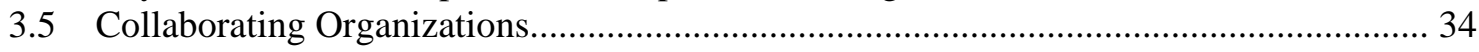

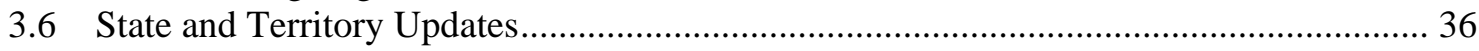

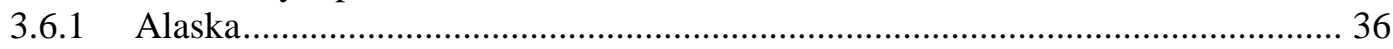

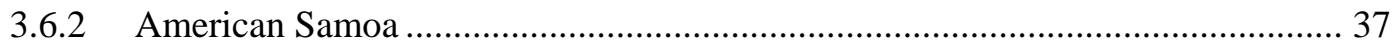

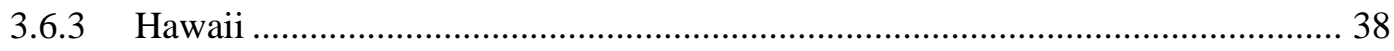

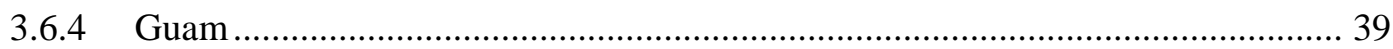

3.6.5 Commonwealth of the Northern Mariana Islands .............................................. 39

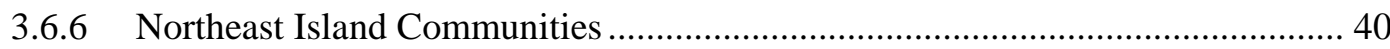

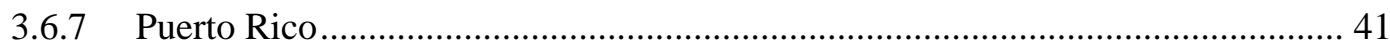

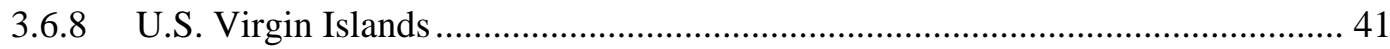

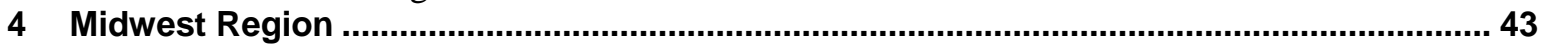

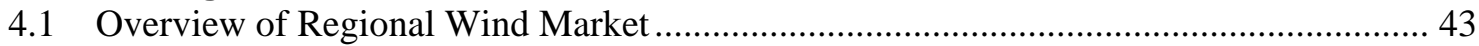

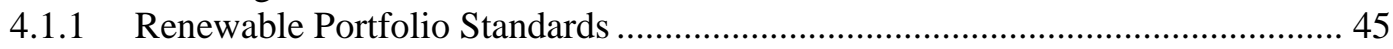

4.1.2 Communities with 100\% Renewable Energy Commitments .............................. 46

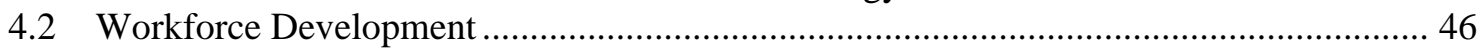

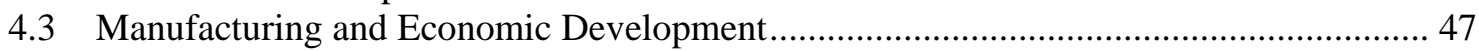

4.4 Key Stakeholder Groups and Development Challenges ................................................ 51

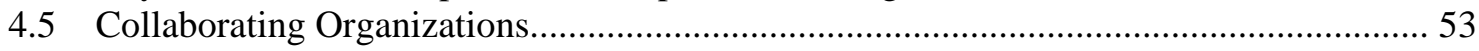

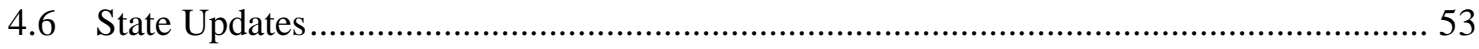

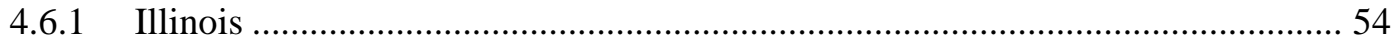

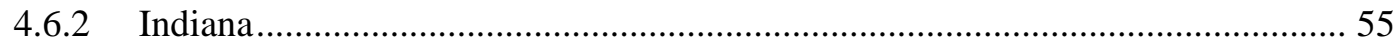

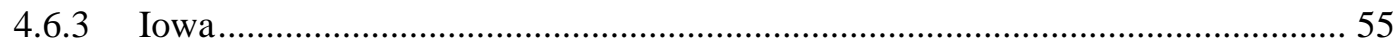

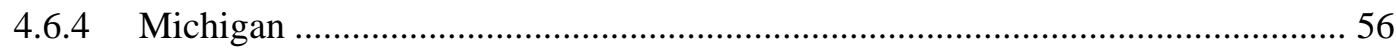

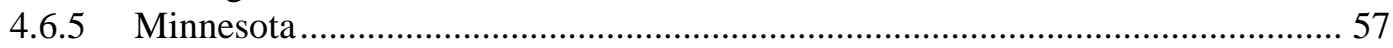

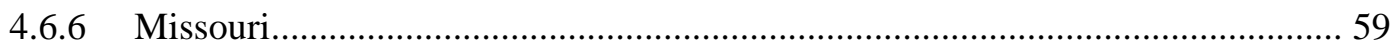

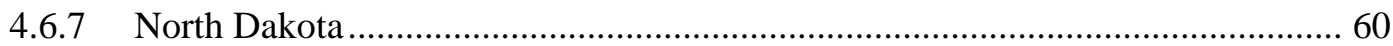




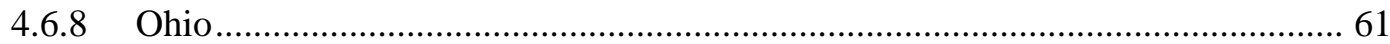

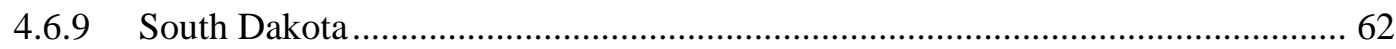

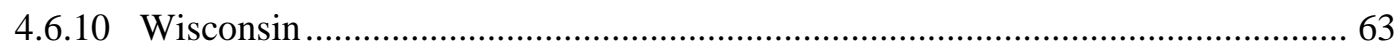

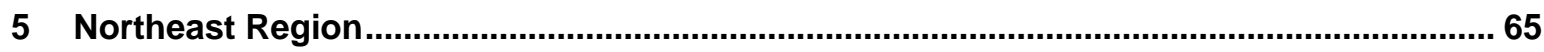

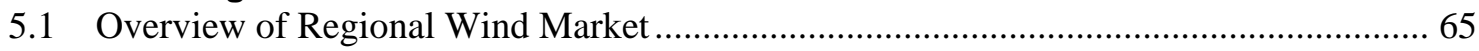

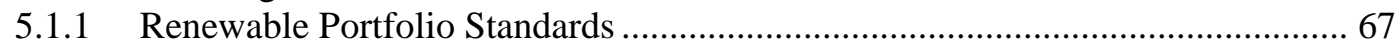

5.1.2 Communities with 100\% Renewable Energy Commitments .............................. 67

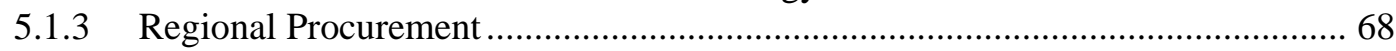

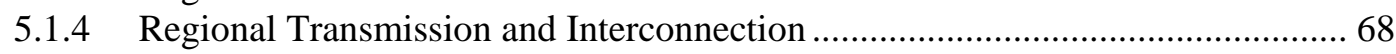

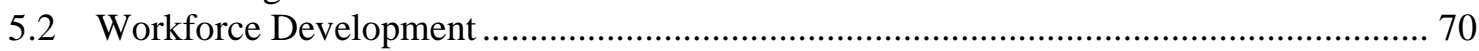

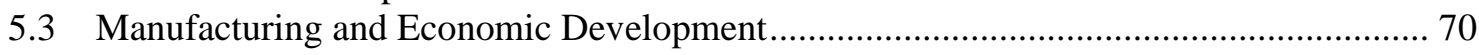

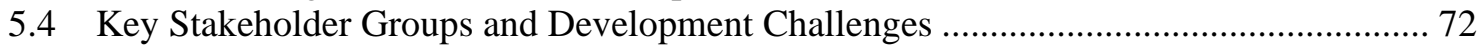

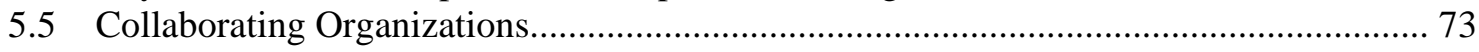

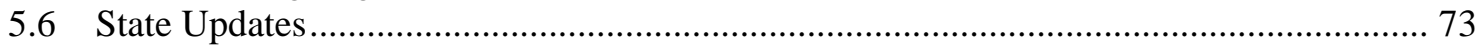

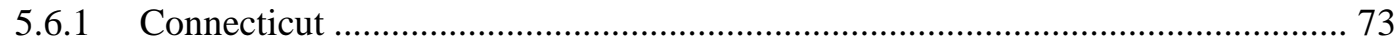

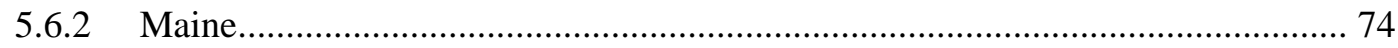

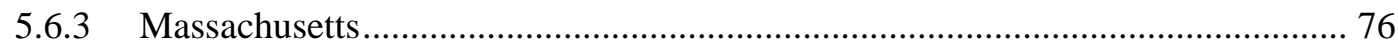

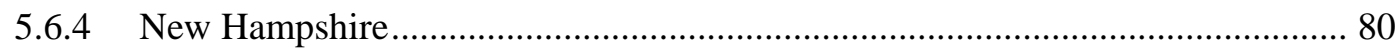

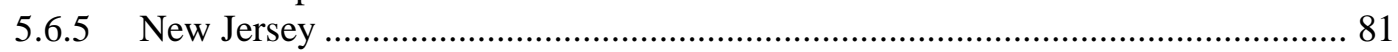

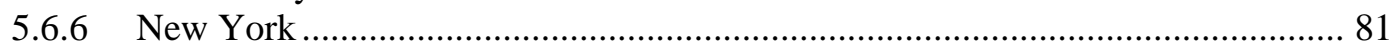

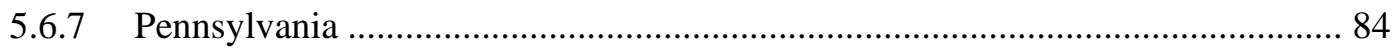

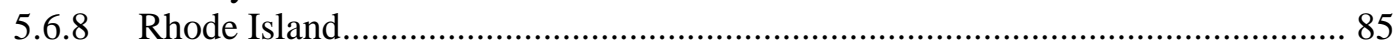

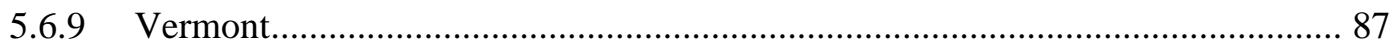

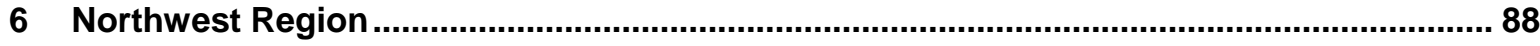

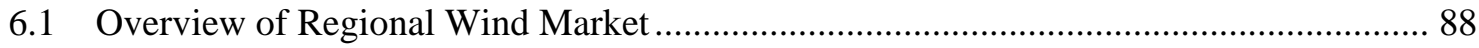

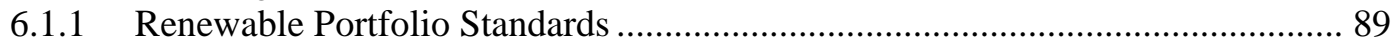

6.1.2 Communities with 100\% Renewable Energy Commitments ................................ 90

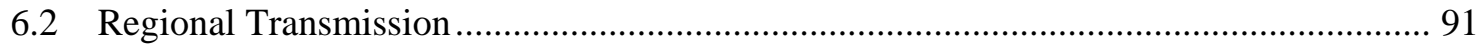

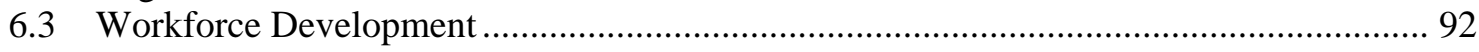

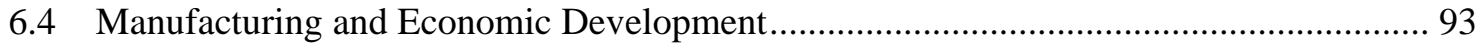

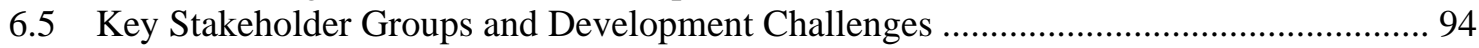

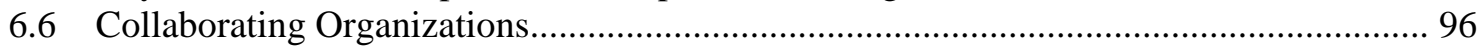

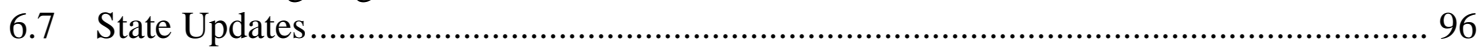

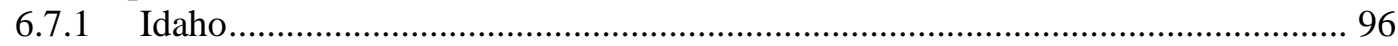

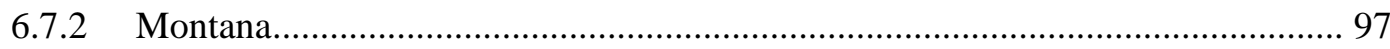

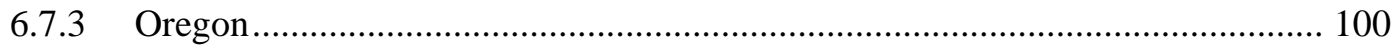

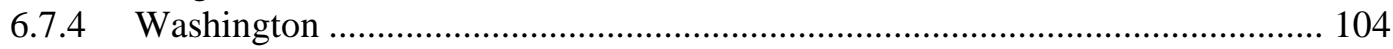

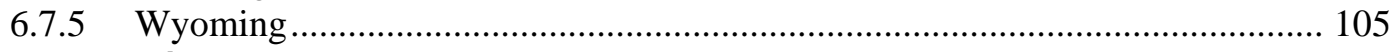

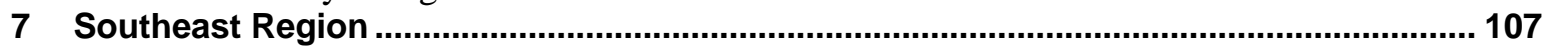

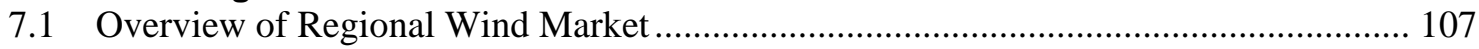

7.1.1 Renewable Portfolio Standards ................................................................... 109

7.1.2 Communities with 100\% Renewable Energy Commitments ............................. 109

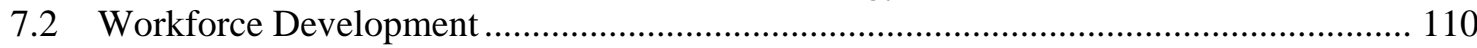

7.3 Manufacturing and Economic Development................................................................ 111

7.4 Key Stakeholder Groups and Development Challenges ........................................... 113

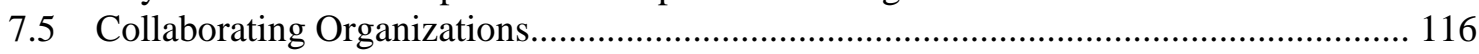

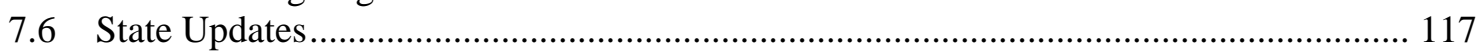

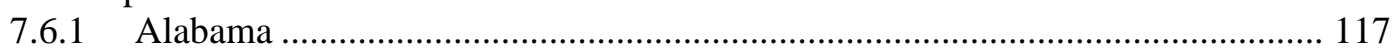

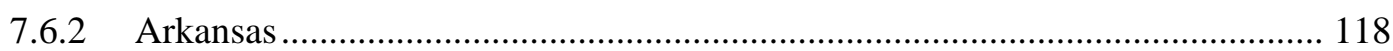

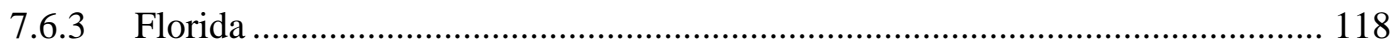

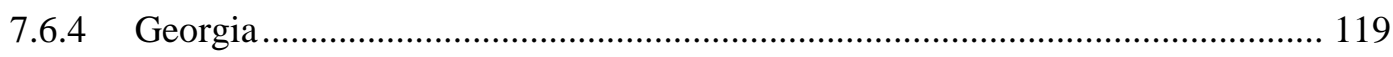




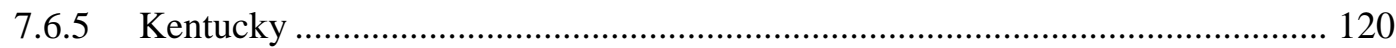

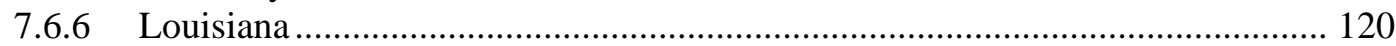

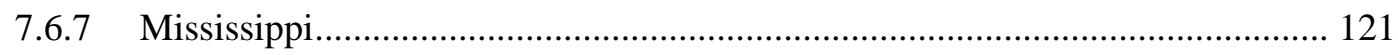

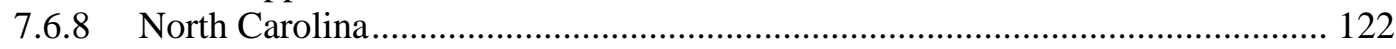

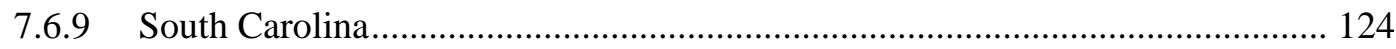

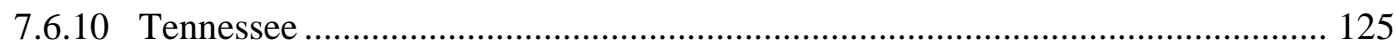

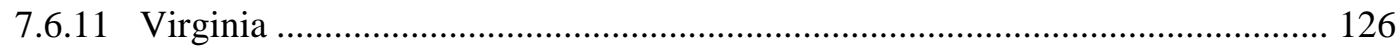

8 Updates for States Outside of RRC Regions .......................................................... 129

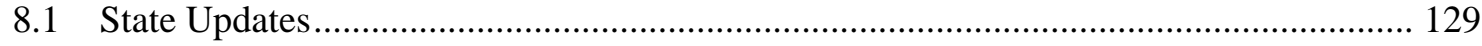

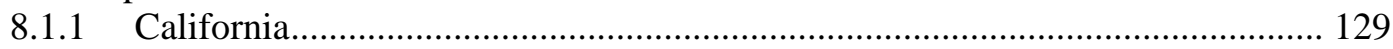

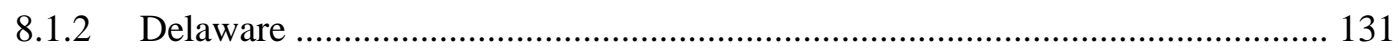

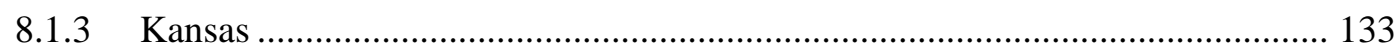

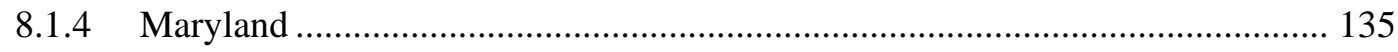

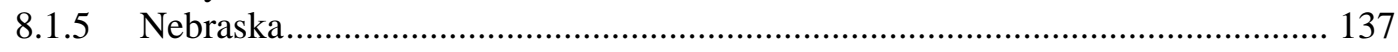

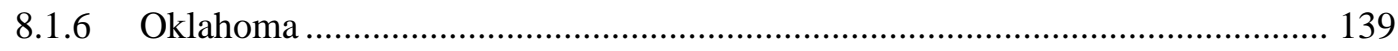

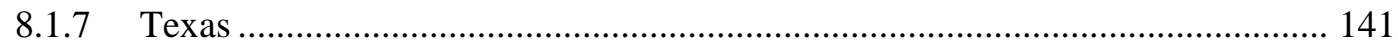

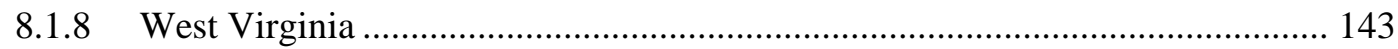

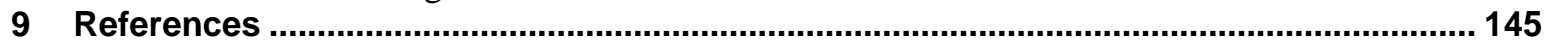




\section{Table of Figures}

Figure 1. Total installed wind capacity in the United States as of December 2017......................... 1 Figure 2. U.S. offshore wind project pipeline by state as of June 2017. Source: National Renewable

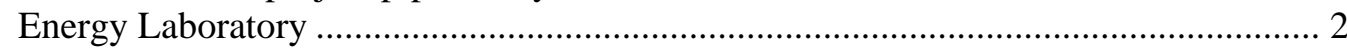

Figure 3. Cumulative U.S. distributed wind capacity additions by state, 2003-2016 ...................... 2

Figure 4. Map of Regional Resource Centers ................................................................................ 3

Figure 5. Map of school wind turbine projects, educational programs, and locations with both wind turbines and educational programs within the states served by the Four Corners Wind

Resource Center

Figure 6. Northern Arizona University students make final adjustments to their turbine components before their wind tunnel testing in the Collegiate Wind Competition 2017 Technical Challenge. The team received an honorable mention for the technical design presentation. Photo by Dennis Schroeder, NREL

Figure 7. The Latigo Wind Park in Utah provides benefits to a rural county with limited development opportunities. Photo from sPower

Figure 8. Unalakleet Valley Electric Cooperative installed six Northwind 100 turbines in November 2009. As of November 2016, the wind farm had generated 7 million kilowatt-hours of power and reduced fuel use in the remote Alaskan community by 70,000 gallons annually. Photo by STG Incorporated, NREL 16797 ............................................... 26

Figure 9. Map of school wind turbine projects, educational programs, and locations with both wind turbines and educational programs within the Islanded Grid Resource Center's area. 30

Figure 10. Map of school wind turbine projects, educational programs, and locations with both wind turbines and educational programs within the Midwest Wind Energy Center's area

Figure 11. The CapX2020 transmission line involves 11 utilities that serve the Upper Midwest. The project is expected to allow increased renewable energy development in the region.

Photo courtesy of CapX2020

Figure 12. Electronic component connections to the University of Wisconsin-Madison's wind turbine load at the 2017 Collegiate Wind Competition. Photo by Dennis Schroeder, NREL

Figure 13. Map of school wind turbine projects, educational programs, and locations with both wind turbines and educational programs within the Northeast Wind Resource Center's area

Figure 14. The Pennsylvania State University team took first place overall and the tunnel testing award at the Collegiate Wind Competition 2017. Photo by Lee Jay Fingersh, NREL 85

Figure 15. The Block Island Wind Farm (as seen from Block Island, Rhode Island) is the first U.S. offshore wind farm. Photo by Dennis Schroeder, NREL 40396

Figure 16. Map of school wind turbine projects, educational programs, and locations with both wind turbines and educational programs within the Northwest Wind Resource and Action Center's area

Figure 17. Greenfield Wind, a 25-MW facility located near Fairfield, Montana, was commissioned in September 2016. Photo from Dick Anderson Construction.

Figure 18. Map of school wind turbine projects, educational programs, and locations with both wind turbines and educational programs within the Southeast Wind Energy Resource Center's area ......

Figure 19. The Southeastern Wind Coalition organized a tour of the Amazon Wind Farm U.S. East, located in Pasquotank and Perquimans Counties in North Carolina. Photo from Avangrid Renewables, NREL 41783

Figure 20. Map of school wind turbine projects, educational programs, and locations with both wind turbines and educational programs in California 
Figure 21. Map of sole educational program location in Delaware.

Figure 22. Map of school wind turbine projects, educational programs, and locations with both wind turbines and educational programs in Kansas.

Figure 23. Kansas State University students connect the electrical components of their wind turbine before wind tunnel testing. The team took home second place overall in the 2017 Collegiate Wind Competition. Photo by Dennis Schroeder, NREL

Figure 24. Map of school wind turbine projects, educational programs, and locations with both wind turbines and educational programs in Maryland

Figure 25. Map of school wind turbine projects, educational programs, and locations with both wind turbines and educational programs in Nebraska ................................................ 139

Figure 26. Map of school wind educational programs in Oklahoma ............................................ 140

Figure 27. Map of school wind turbine projects, educational programs, and locations with both wind turbines and educational programs in Texas .................................................. 142

Figure 28. Map of sole school wind educational program in West Virginia ................................ 144 


\section{Table of Tables}

Table 1. Key Statistics for States in the Four Corners Wind Resource Center Region ...................... 8

Table 2. RPS Overview for States Served by the Four Corners Wind Resource Center .................... 9

Table 3. Communities Served by the Four Corners Wind Resource Center with 100\% Renewable

Energy Commitments .....

Table 4. Wind-Related Manufacturing Overview for States Served by the Four Corners Wind

Resource Center ................................................................................................... 12

Table 5. Economic Impacts of Wind Development in States Served by the Four Corners Wind

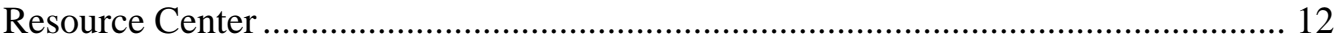

Table 6. Key Statistics for the Islanded Grid Resource Center Region ........................................... 27

Table 7. RPS Overview for States and Territories Served by the Islanded Grid Resource Center... 28

Table 8. Community Served by the Islanded Grid Regional Resource Center with 100\% Renewable

Energy Commitments

Table 9. Economic Impacts of Wind Development in States Served by the Islanded Grid Resource

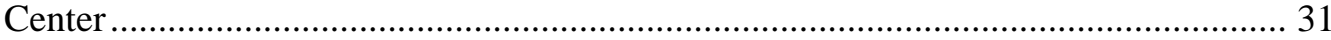

Table 10. Key Statistics for States in the Midwest Wind Energy Center Region............................ 43

Table 11. RPS Overview for States Served by the Midwest Wind Energy Center........................... 45

Table 12. Communities Served by the Midwest Regional Resource Center with 100\% Renewable

Energy Commitments .............................................................................................. 46

Table 13. Wind-Related Manufacturing Overview for States Served by the Midwest Wind Energy

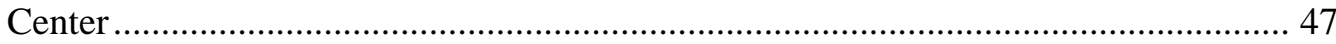

Table 14. Economic Impacts of Wind Development in States Served by the Midwest Wind Energy

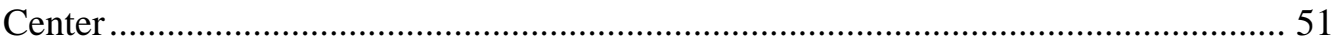

Table 15. Key Statistics for States in the Northeast Wind Resource Center Region ........................ 66

Table 16. RPS Overview for States Served by the Northeast Wind Resource Center...................... 67

Table 17. Communities Served by the Northeast Regional Resource Center with 100\% Renewable

Energy Commitments ................................................................................................. 68

Table 18. Wind-Related Manufacturing Overview for States Served by the Northeast Wind

Resource Center .......................................................................................................... 71

Table 19. Economic Impacts of Wind Development in States Served by the Northeast Wind

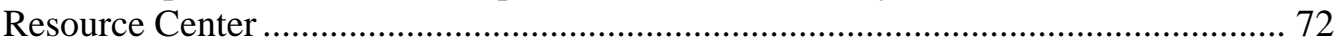

Table 20. Key Statistics for States in the Northwest Wind Resource and Action Center Region .... 89

Table 21. RPS Overview for States Served by the Northwest Wind Resource and Action Center.. 90

Table 22. Communities Served by the Northwest Regional Resource Center with 100\% Renewable

Energy Commitments .................................................................................................. 91

Table 23. Wind-Related Manufacturing Overview for States Served by the Northwest Wind

Resource and Action Center........................................................................................ 93

Table 24. Economic Impacts of Wind Development in States Served by the Northwest Resource

and Action Center ....................................................................................................... 94

Table 25. Key Statistics for States in the Southeast Wind Energy Resource Center Region ......... 108

Table 26. RPS Overview for States Served by the Southeast Wind Energy Resource Center ....... 109

Table 27. Communities Served by the Southeast Regional Resource Center with 100\% Renewable

Energy Commitments 109

Table 28. Wind-Related Manufacturing Overview for States Served by the Southeast Wind Energy

Resource Center

Table 29. Economic Impacts of Wind Development in States Served by the Southeast Wind Energy

Resource Center 
Table 30. California Wind-Related Manufacturing Overview 131

Table 31. Kansas Wind-Related Manufacturing Overview . 135

Table 32. Maryland Wind-Related Manufacturing Overview .

137

Table 33. Oklahoma Wind-Related Manufacturing Overview 141

Table 34. Texas Wind-Related Manufacturing Overview 


\section{Introduction}

In 2017, wind energy became the largest source of renewable electric capacity in the United States (and the fourth largest overall). As of the end of 2017, the United States is home to more than 89,000 megawatts of installed wind capacity (Figure 1), enough to power 26 million average American homes (American Wind Energy Association 2018).

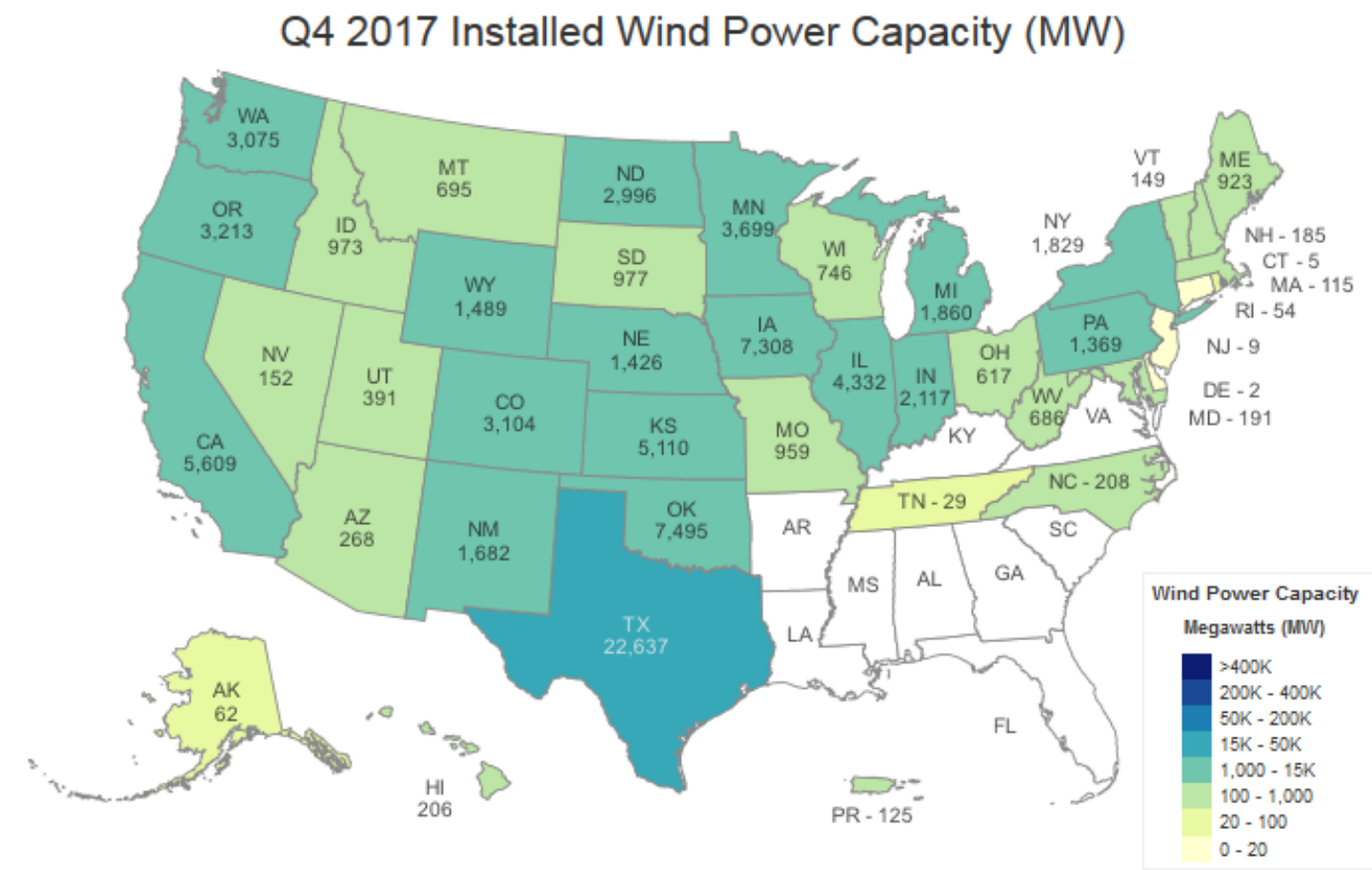

Total Installed Wind Capacity: 89,078 MW

Source: American Wind Energy Association Market Report

Figure 1. Total installed wind capacity in the United States as of December 2017

The U.S. Department of Energy's (DOE) Wind Vision Report ${ }^{4}$ assesses the potential economic, environmental, and social benefits of a scenario in which U.S. wind power supplies $10 \%$ of the nation's electrical demand in 2020, 20\% in 2030, and 35\% in 2050. According to the Wind Vision, wind energy supports a strong domestic supply chain, is affordable and can save consumers money, reduces air pollution emissions, preserves water resources, and increases community revenues. Despite wind energy becoming the largest source of renewable electric capacity in the United States in 2017, further significant expansion of wind energy development would be required to achieve the scenarios outlined in the DOE's Wind Vision and to allow U.S. consumers to have access to affordable wind energy and to realize the benefits outlined in the scenarios.

Offshore wind can play a large role in expanding wind energy development in the country, and in 2016, the U.S. industry took a major step forward with the commissioning of the nation's first

\footnotetext{
${ }^{4}$ https://www.energy.gov/eere/wind/wind-vision
} 
offshore project, the 30-MW Block Island project in Rhode Island. Many more states have offshore wind projects in the pipeline (Figure 2).

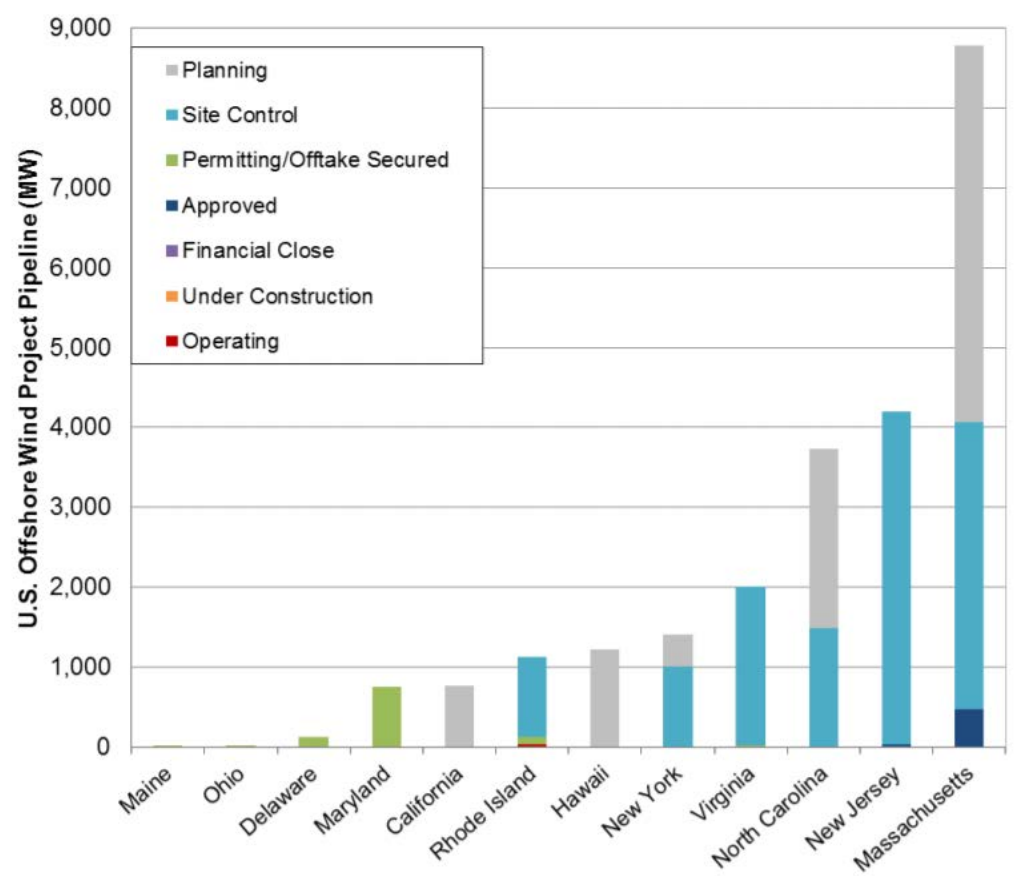

Figure 2. U.S. offshore wind project pipeline by state as of June 2017. Source: National Renewable Energy Laboratory

Distributed wind capacity increases also contribute to achieving scenarios such as those outlined in the Wind Vision Report. Figure 3 shows cumulative capacity additions of distributed wind by state.

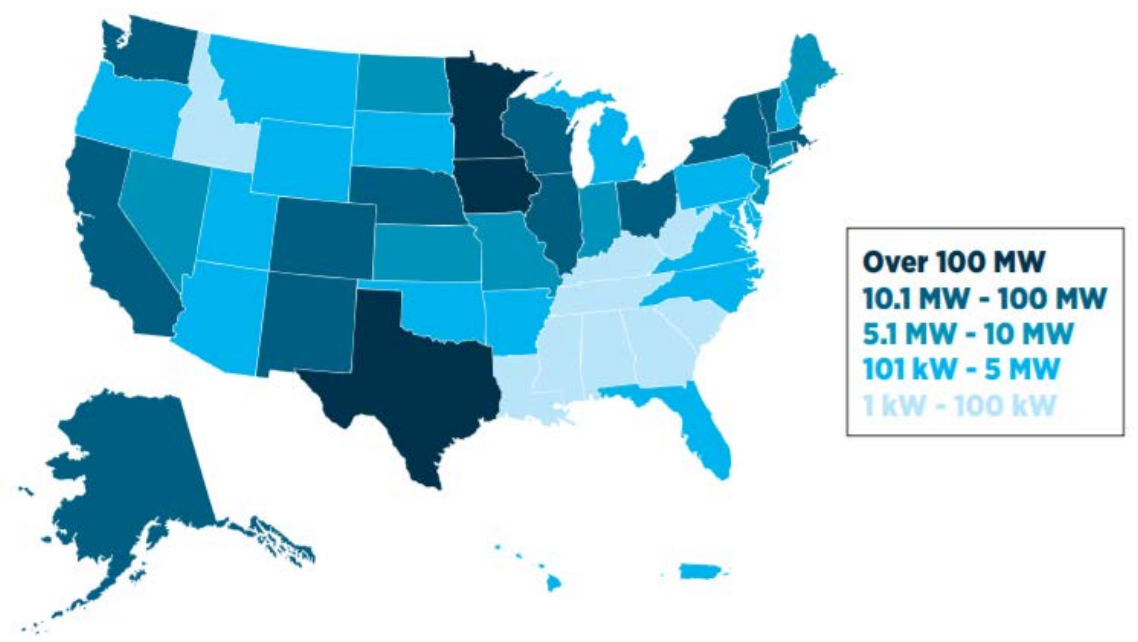

Figure 3. Cumulative U.S. distributed wind capacity additions by state, 2003-2016 
The wind industry and the DOE Wind Energy Technologies Office are addressing technical challenges to increasing wind energy's contribution to the national grid (such as reducing turbine costs and increasing energy production and reliability). ${ }^{5}$ The Office also recognizes that access to factual information leads to smart community decisions about wind siting development; credible information about wind energy and the diversity of its possible applications should be communicated to a variety of stakeholders. As a result of this recognition, in 2014 DOE established Regional Resource Centers (RRCs). Located across six U.S. regions, from the Northeast Wind Resource Center touching northern-most Maine to the Islanded Grid Regional Resource Center serving Alaska and Hawaii, RRCs provide local information about wind energy and are comprised of organizations that provide fact-based resources from a range of local leaders with technical and community expertise. Figure 4 depicts the geographic coverage of the RRCs.

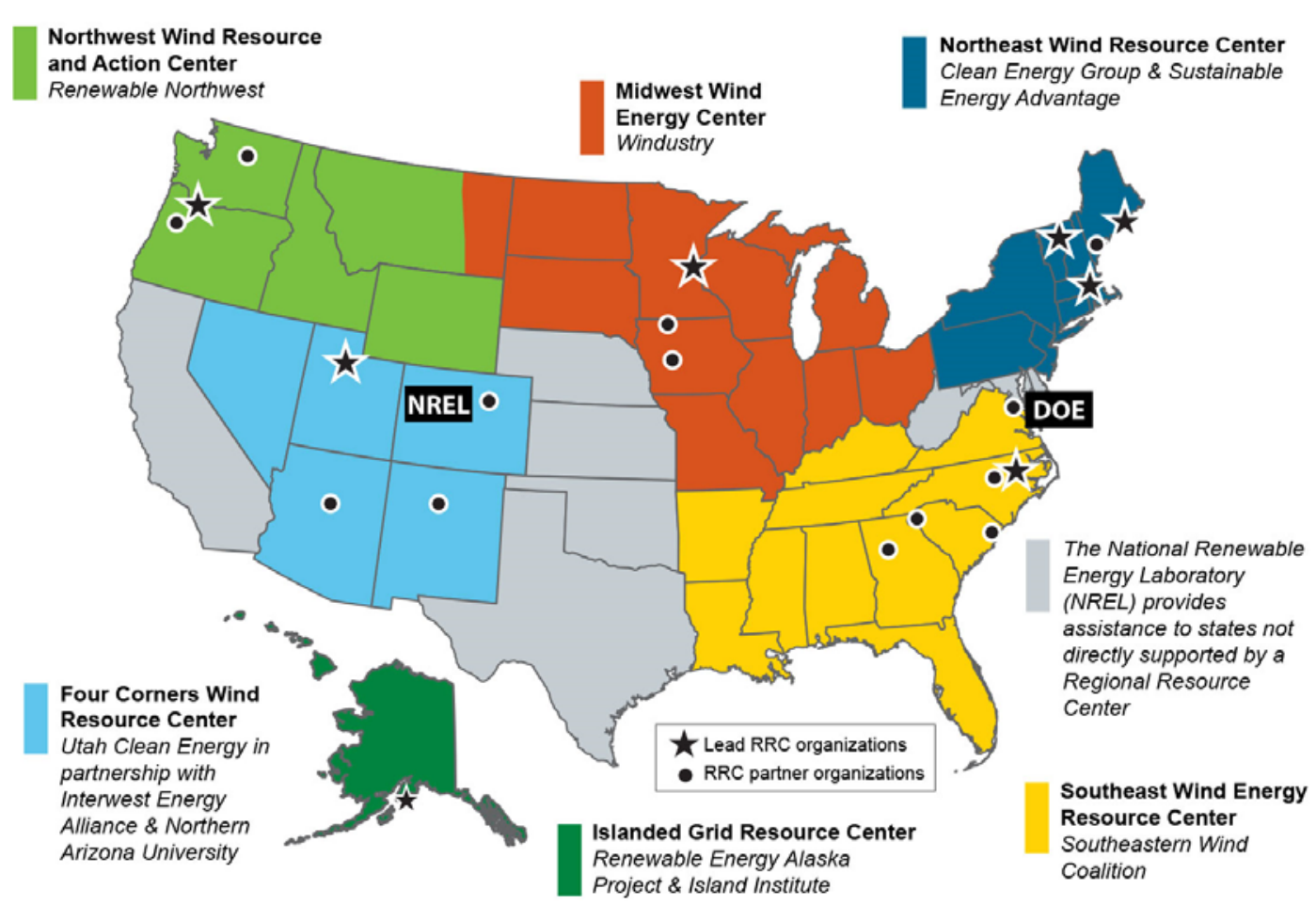

Figure 4. Map of Regional Resource Centers

The RRCs are as follows (in alphabetical order here and in the report sections):

- Four Corners Wind Resource Center, serving Arizona, Colorado, New Mexico, Utah, Nevada, and part of Wyoming

- Islanded Grid Resource Center, serving Alaska, Maine, Massachusetts, Rhode Island, Hawaii, Guam, American Samoa, Commonwealth of Northern Marianas, and U.S. Virgin Islands

\footnotetext{
${ }^{5}$ See the Wind Energy Technologies Office projects map at https://energy.gov/eere/wind/wind-energy-technologiesoffice-projects-map
} 
- Midwest Wind Energy Center, serving eastern Montana and Illinois, Indiana, Iowa, Michigan, Minnesota, Missouri, North Dakota, Ohio, South Dakota, and Wisconsin

- Northeast Wind Resource Center, serving New England (Connecticut, Maine, Massachusetts, New Hampshire, Rhode Island, and Vermont) and New York for landbased wind, and that same region plus New Jersey for offshore wind

- Northwest Wind Resource and Action Center, serving Washington, Oregon, Idaho, western Montana, and part of Wyoming

- Southeast Wind Energy Resource Center, serving North Carolina, Florida, Louisiana, South Carolina, Georgia, Alabama, Mississippi, Virginia, Kentucky, Tennessee, and Arkansas.

The DOE WINDExchange ${ }^{6}$ initiative provides additional information to the RRCs and states not supported by one of these organizations.

Each RRC works with local stakeholders such as county commissioners, state legislators, landowners, tribal authorities, and organizations like utilities, schools, and non-profit agencies. As part of DOE's WINDExchange initiative, the RRCs produce relevant, actionable, and factbased information about the benefits and impacts of wind energy and deliver that information to these local stakeholders. During their second year of operations, the RRCs reached more than 1.3 million stakeholders with targeted activities (e.g., meetings with county commissioners, targeted webinars); 93,000 of those were identified as key stakeholders (e.g., state, county, and local officials). The RRCs indicated that approximately 68,700 of the more than 1.3 million stakeholders reached took actions, demonstrating a wider acceptance of wind technology development than before the RRC involvement. Actions included writing a letter to the editor, including wind energy as an option in a state's energy portfolio, etc. The RRCs provide information on regional topics such as supply chain, workforce, wind resource, geography, wildlife, electricity infrastructure, and costs.

The goals of the DOE RRC project include making it easier for stakeholders and decision makers to decide whether responsible and appropriate wind project development should be deployed in their communities by:

- Producing relevant, actionable, and fact-based information

- Delivering that information in useful forms to those who need it when they need it.

Being experts in their regions, the RRCs identified a wide array of market challenges that continue to hinder wider-scale developments of wind technologies. These issues include:

- Insufficient transmission capacity and the need for transmission improvements

- Power market conditions that limit wind development (such as small balancing areas and hour-ahead dispatching)

- Lack of local wind siting or zoning ordinances; ordinances that do not reflect best practices or do not allow the flexibility in wind development to address small, distributed, community, or utility-scale wind projects

\footnotetext{
${ }^{6} \underline{\text { http://apps2.eere.energy.gov/wind/windexchange/ }}$
} 
- Lack of clear federal policy covering wind power-related initiatives and awareness of those policies

- Minimal public education and engagement of wind siting issues, exacerbated by misinformation and negative public opinion regarding wind energy

- Lack of understanding about wind energy's economic impacts, including local tax benefits, jobs and economic development, and turbine manufacturing

- State and regional competition

- Challenges with development on federal and native lands

- Accurate wind information not being utilized in utility integrated resource and statebased clean energy planning (resulting in a need to advance the state of the art in power sector resource planning processes)

- Delayed projects becoming much more costly for developers

- Restricted access to capital; limited financing, funding, and technical assistance for small/community/distributed wind development.

The RRCs also identified the following issues as unique to offshore wind development:

- The current high costs of offshore wind energy and lack of articulated benefits describing why initial high costs for early projects will lead to reduced costs for future projects

- Minimal independent information and outreach geared toward innovative regional procurement targets, limiting the ability of projects to attract financing, investigate alternative financing mechanisms, and initiate regional supply chain development

- The fact that there are few full-scale offshore wind turbines currently deployed in the United States and therefore limited U.S.-based research about actual offshore wind development. This limited research results in limited information regarding the offshore wind regulatory process; technical issues related to installation, interconnection, and operation; environmental and human use impacts; and acceptance of offshore wind

- Lack of clear understanding of the regional and national market opportunity for offshore wind development.

The RRCs also identified distinct challenges unique to wind development in isolated, islanded power systems found primarily in Alaska, coastal New England, Hawaii, the Territories of the United States, and international locations. The primary development challenges include:

- The high up-front cost of deploying sophisticated wind technologies and associated hardware in an isolated, remote, or islanded area with relatively low technical and human capacity

- Excessive transportation and mobilization costs, much higher than costs for communities in other regions on the road system

- Limited ability to gain economies of scale due to the relatively small project size

- Lack of experience and extra costs of integrating wind into smaller, less flexible electric grids

- Lack of clear regulatory policy and examples that define the rules of engagement between small utilities and independent power producers that wish to develop wind energy supplied to small, typically municipal utilities 
- Additional wind energy development challenges have been identified that relate to expanded wind integration into the Railbelt transmission system ${ }^{7}$ in Alaska, which are discussed in the state summary in this document.

This report includes an update for all 50 states; states not served by an RRC are covered in Section 8. Each RRC section describes the regional and state markets for wind development, including current Renewable Portfolio Standard policies and communities with 100\% renewable energy commitments. Each section discusses workforce development efforts (including updates for DOE's Collegiate Wind Competition and Wind for Schools project), the state of manufacturing and wind energy-related economic development in the region, key stakeholder groups and development challenges, and a list of collaborating organizations. The report also provides updates on each RRCs' efforts to provide accurate and credible information for use in regional discussions and enable balanced consideration of potential developments in areas where wind projects could be built.

This document is intended to complement the DOE's annual Distributed Wind Market Report (U.S. DOE 2017a), annual Wind Technologies Market Report (U.S. DOE 2017c), and periodic Offshore Wind Technologies Market Report (U.S. DOE 2017b), which provide assessments of the national wind markets for each of these technologies.

Please note that the authors anticipated that readers might only read the sections of the report that pertain to their regions; therefore, it was important that each section be able to stand alone. If a person reads the report from start to finish, he or she will note redundancies and duplicated content.

\footnotetext{
${ }^{7}$ A small, isolated transmission system in Alaska that covers the state's population centers along the main railroad line, including the Seward, the Kenai, Anchorage, Wasilla, and north to Fairbanks.
} 


\section{Four Corners Region}

Colleagues from the Four Corners Wind Resource Center (4CWRC) and the National Renewable Energy Laboratory (NREL) collaborated to provide the following assessment of the state of the wind industry in this region.

The 4CWRC ${ }^{8}$ is managed by Utah Clean Energy in partnership with Interwest Energy Alliance ${ }^{9}$ and Northern Arizona University. ${ }^{10}$ The Regional Resource Center (RRC) engages and educates wind energy stakeholders in Arizona, Colorado, Nevada, New Mexico, Utah, and Wyoming (see Figure 4) ${ }^{11}$ Collaborating in this region allows the 4CWRC to leverage the experience of states with more historic wind development experience - like Colorado, Wyoming, and New Mexicoto inform stakeholders and expand markets in Utah, Nevada, and Arizona, including on tribal lands. Additionally, the commonalities among the states enable a centralized approach to addressing wind barriers that further leverages resources and efforts within the region. For example, as the region experiences increasing droughts and water shortages, these arid Southwest states share an interest in water conservation and water-wise energy resources.

Similarly, air quality and haze related to the region's fossil fuel-intensive energy mix are increasingly critical issues for Four Corners states. Recent developments that support wind expansion include the availability of the federal Production Tax Credit and the overall cost declines due to technology improvements and other factors. In many cases, wind energy has become the lowest-cost energy source available to utilities. The 4CWRC's efforts focus on promoting the cost-competitive nature of wind along with the water-saving, air quality, and emissions mitigation benefits of wind energy. Coordination and engagement on relevant Western regional transmission, integration, and interconnection issues, including the implementation of an energy imbalance market ${ }^{12}$ and the emergence of a potential regional energy market, ${ }^{13}$ support regional and national efforts to address key barriers to expanding wind power in the Western market.

\subsection{Overview of Regional Wind Market}

Total installed wind capacity in the 4CWRC region as of October 2017 is 5,597 megawatts (MW) (Table 1). The Wind Vision Central Study Scenario would result in a total installed capacity of approximately 21,000 MW by the year 2050 (U.S. Department of Energy 2015e). Stakeholders can consult the U.S. Department of Energy's (DOE's) interactive Wind Vision

\footnotetext{
${ }^{8}$ http://www.fourcornerswind.org/

9 http://interwest.org/

${ }^{10} \mathrm{http}: / /$ nau.edu/

${ }^{11}$ Although the 4CWRC contributes to engagement efforts in Wyoming, in this report the state's overview is included in the Northwest Wind Resource and Action Center's section.

12 An energy imbalance market is a means of supplying and dispatching electricity to balance fluctuations in generation and load. It aggregates the variability of generation and load over multiple balancing authority areas.

${ }^{13}$ Western states and the California Independent System Operator are considering the benefits of a regional energy market to support better use of resources, especially renewables, to reduce system costs and greenhouse gas emissions from the electricity sector.
} 
Study Scenario Viewer ${ }^{14}$ to learn more about state-specific costs, benefits, and other impacts from wind energy development related to the Wind Vision scenarios.

Table 1. Key Statistics for States in the Four Corners Wind Resource Center Region

\begin{tabular}{llllll}
\hline & AZ & CO & NM & NV & UT \\
\hline $\begin{array}{l}\text { Installed Wind (MW), End of 4Q17 } \\
\text { Percentage of In-State Energy Production }\end{array}$ & 268 & 3,104 & 1,682 & 152 & 391 \\
\hline $\begin{array}{l}\text { (as of End of 2016) } \\
\text { 16 }\end{array}$ & $.5 \%$ & $17.3 \%$ & $10.9 \%$ & $.9 \%$ & $2.2 \%$ \\
$\begin{array}{l}\text { 2017 Wind Power Capacity Additions } \\
\text { (MW) }\end{array}$ & 0 & 75 & 569.60 & 0 & 0 \\
$\begin{array}{l}\text { Wind Capacity under Construction (MW), } \\
\text { end of 4Q17 }\end{array}$ & 0 & 0 & 980 & 0 & 0 \\
$\begin{array}{l}\text { Projected Potential Capacity (MW), 80 m, } \\
\text { 30\% Capacity Factor }\end{array}$ & 10,904 & 387,220 & 492,083 & 7,247 & 13,103 \\
\hline $\begin{array}{l}\text { Projected Potential Capacity (MW), 100 } \\
\text { m, 30\% Capacity Factor }\end{array}$ & 25,791 & 429,456 & 568,112 & 12,034 & 26,237 \\
$\begin{array}{l}\text { Distributed Wind Capacity, as of } \\
\text { December 2016 (MW) }\end{array}$ & 1.1 & 27.3 & 36.3 & 8.9 & 4.0 \\
\hline
\end{tabular}

Sources: American Wind Energy Association, U.S. DOE

\subsubsection{Renewable Portfolio Standards}

Renewable portfolio standard (RPS) policies are a key driver of wind energy development in the interior West. To date, all states in the 4CWRC region have continued their RPS programs and are moving toward their targets.

Two of the states in the 4CWRC region have an RPS targeting 2020 (Colorado and New Mexico), two have an RPS targeting 2025 (Arizona and Nevada), and Utah has a renewable portfolio goal instead of a standard (Table 2). Arizona is considering doubling its renewable standard from $15 \%$ by 2025 to $30 \%$ by 2030, although a timeline for amending the existing rule has not been established. Several RPSs in the region survived challenges brought in court, and neighboring states California and Washington increased their RPSs.

Legislation to reduce or otherwise roll back the Colorado and New Mexico RPSs were introduced during the 2015 and 2016 legislative sessions but did not pass. In 2015, New Mexico's House of Representatives voted in favor of reducing the $20 \%$ by 2020 renewable energy requirement. The effort stalled when the Senate's Conservation Committee voted to keep the bill from advancing to a full Senate vote. Also in 2015, Colorado’s Senate Bill 44 intended to

\footnotetext{
${ }^{14}$ http://en.openei.org/apps/wv_viewer/

${ }^{15}$ American Wind Energy Association 2018

${ }^{16}$ American Wind Energy Association 2017a

17 American Wind Industry Association 2018

${ }^{18}$ American Wind Industry Association 2018

${ }^{19}$ Distributed wind project capacity is defined as cumulative capacity, 2003-2016 (DOE 2017a).
} 
halve the state's $30 \%$ by 2020 renewable requirement for large utilities while reducing the standard for rural electricity associations from $20 \%$ to $15 \%$ beginning in 2020. The state's House of Representatives voted down the effort. The constitutionality of the state's RPS was also upheld in the Tenth Circuit Court of Appeals, ending litigation that began in 2011.

In Colorado's 2016 legislative session, a few bills were introduced that could have directly or indirectly impacted the state's RPS. SB16- $007^{20}$ would have created incentives for biomass electricity generation to meet RPS goals, without expanding the overall RPS. In 2017, there were fewer rollback attempts in Colorado and the other Four Corners states. In fact, the Nevada State Assembly attempted to expand the state's RPS to $40 \%$ by 2030 , up from the current $25 \%$ by 2025 goal through the passage of AB206. ${ }^{21}$ The Governor vetoed the bill in June 2017.

Table 2. RPS Overview for States Served by the Four Corners Wind Resource Center

\begin{tabular}{ll}
\hline & RPS \\
\hline Arizona & $15 \%$ by 2025 \\
& $30 \%$ by 2020 (investor-owned utilities) \\
& $20 \%$ by 2020 (co-ops serving 100,000 or more meters) \\
& $10 \%$ by 2020 (co-ops serving fewer than 100,000 meters and \\
Colorado & municipal utilities serving 40,000 or more customers) \\
Nevada & $25 \%$ by 2025 \\
New Mexico & $20 \% \times 2020$ (investor-owned utilities) \\
Utah & $10 \% \times 2020$ (electric co-ops) \\
\hline
\end{tabular}

Source: Database of State Incentives for Renewables \& Efficiency

\subsubsection{Communities with $100 \%$ Renewable Energy Commitments}

Many state public utility commissions are working with utilities to choose the direction of their energy portfolios. While some states have mandated and voluntary renewable energy goals or standards, some cities have taken an additional step to create their own commitments to clean energy, some of which exceed levels established by their states.

${ }^{20}$ https://leg.colorado.gov/bills/sb16-007

${ }^{21}$ https://www.leg.state.nv.us/App/NELIS/REL/79th2017/Bill/5003/Overview 
Table 3. Communities Served by the Four Corners Wind Resource Center with $100 \%$ Renewable Energy Commitments

\begin{tabular}{lll}
\hline City & State & Target Year \\
\hline Aspen & CO & Achieved in 2015 \\
Angel Fire & NM & 2030 \\
Boulder & CO & 2030 \\
\hline Eagle Nest & NM & 2030 \\
\hline Nederland & CO & 2025 \\
\hline Moab & UT & 2032 \\
\hline Park City & UT & 2032 \\
\hline Pueblo & CO & 2035 \\
\hline Questa & NM & 2030 \\
\hline Red River & NM & 2030 \\
Salt Lake City & UT & 2032 \\
\hline Taos & NM & 2030 \\
\hline Taos Ski Valley & NM & 2030 \\
\hline
\end{tabular}

Source: Sierra Club

\subsection{Workforce Development}

The region supported by the 4CWRC has a developed wind energy education infrastructure with colleges or universities active in all six states in the region. Stakeholders in Arizona and Colorado are active in wind energy workforce development and participate in DOE's Wind for Schools Project and Collegiate Wind Competition. New Mexico is home to Mesalands Community College and the North American Wind Research \& Training Center; see each state section in this report for specifics. Also visit the WINDExchange website for information and interactive maps regarding workforce development, the DOE Collegiate Wind Competition, DOE's Wind for Schools project, school wind project locations, and locations of education and training programs in the 4CWRC region and other states. ${ }^{22}$

${ }^{22}$ https://windexchange.energy.gov/education-workforce 


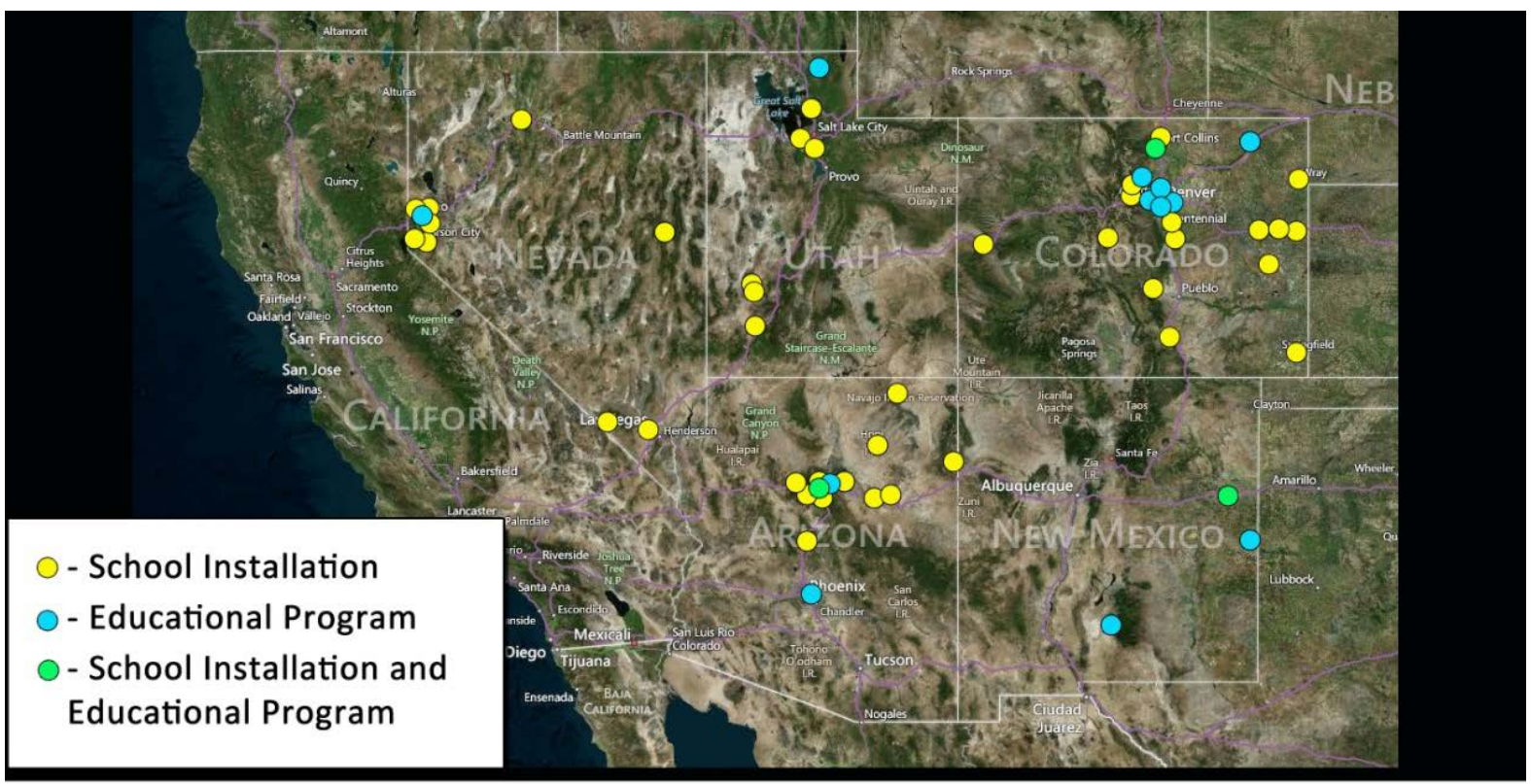

\section{Four Corners Wind Resource Center \\ (NV, UT, CO, AZ, NM)}

Figure 5. Map of school wind turbine projects, educational programs, and locations with both wind turbines and educational programs within the states served by the Four Corners Wind Resource Center

\subsubsection{North American Wind Energy Academy}

Northern Arizona University (NAU) supports the North American Wind Energy Academy (NAWEA), ${ }^{23}$ a non-profit established to facilitate the growth of wind power into a cost-effective, high-penetration, sustainable national energy source producing at least 10 times the 2012 electricity production levels. NAWEA is a collaboration of North America's foremost university professors and researchers working together to overcome the challenges of advancing wind power technology. The Academy-led by professors from Iowa State University, NAU, and Texas Tech-works primarily in four areas: educating students; fostering research; developing and disseminating scientific information; and supporting manufacturing and job creation. NAWEA hosts a biennial symposium, held in Blacksburg, Virginia, in 2015 and in Ames, Iowa, in 2017.

\subsection{Manufacturing and Economic Development}

In the region supported by the 4CWRC, Arizona and Colorado have wind energy-related manufacturing facilities. Table 4 lists these facilities, compiled by NREL researchers as part of DOE’s annual wind market report effort (U.S. Department of Energy 2017c).

${ }^{23}$ http://www.nawea.org/ 
Table 4. Wind-Related Manufacturing Overview for States Served by the Four Corners Wind Resource Center

\begin{tabular}{llll}
\hline Name & City & State & Component \\
\hline Copper State Bolt and Nut & Phoenix & AZ & Fasteners \\
Valley Forge Bolt and Manufacturing & Phoenix & AZ & Fasteners \\
\hline Aluwind & Castle Rock & CO & Tower internals \\
\hline Creative Foam & Berthoud & CO & Blade cores \\
\hline O'Neal Steel & Pueblo & CO & Tower internals \\
\hline PMC Technology & Golden & CO & Hydraulics \\
\hline Primus Windpower & Lakewood & CO & Distributed wind turbines \\
\hline SGB USA & Wheat Ridge & CO & Electrical \\
\hline Vestas & Brighton & CO & Blades \\
Vestas & Brighton & CO & Turbine (nacelle assembly) \\
Vestas & Pueblo & CO & Towers \\
Vestas & Windsor & CO & Blades \\
Woodward Governor & Fort Collins & CO & Inverters \\
\hline
\end{tabular}

Additional economic impacts from wind development include the capital investment, jobs supported, tax revenues paid, payments in lieu of taxes, and land lease payments made by wind developers during construction and the ongoing operation of wind plants. The American Wind Energy Association performs modeling work that identifies the impacts of all wind-related investment. Table 5 summarizes the total jobs and capital investment over time in wind farms in the region in which the 4CWRC operates. Examples of economic impacts are provided in each of the state overviews below.

Table 5. Economic Impacts of Wind Development in States Served by the Four Corners Wind Resource Center

\begin{tabular}{lll}
\hline State & Direct and Indirect Jobs Supported & Total Capital Investment \\
\hline Arizona & $501-1,000$ & $\$ 573$ million \\
\hline Colorado & $6,001-7,000$ & $\$ 5.9$ billion \\
\hline Nevada & $1-100$ & $\$ 306$ million \\
\hline New Mexico & $1,001-2,000$ & $\$ 2$ billion \\
Utah & $101-500$ & $\$ 851$ million \\
\hline
\end{tabular}

Source: American Wind Energy Association 2017a, as of 2016

\subsection{Key Stakeholder Groups and Development Challenges}

The 4CWRC targets three stakeholder groups:

- Utility regulators, commissioners, utility representatives, and staff

- State, local, and tribal decision makers and staff 
- Interested members of the public.

The information provided to these stakeholder groups addresses the following wind energy development market barriers that are prevalent in this region. Each barrier is followed by a more detailed description specific to the Four Corners Region and an example of the 4CWRC's work to address the barrier with their stakeholders.

Insufficient transmission capacity that can hinder wind growth in the region. Historical transmission capacity, built to deliver electricity from large fossil fuel power plants to load, was not designed to accommodate new wind development. In some cases, fossil fuel plants were not located in windy areas and/or the lines were not designed to have sufficient available capacity to add wind energy. Development of new wind energy projects in the region is limited without additional transmission lines and better use of existing lines.

Changes occurring in the 4CWRC region will make more transmission capacity available in the near future. Two of the region's major coal plants have announced retirement plans based primarily on cost-competitiveness with other types of generation (Randazzo 2017, RobinsonAvila 2017). Retirement for the 2,250-MW Navajo Generating Station in Arizona is anticipated by the end of 2019. PNM, the majority owner of the 1,800-MW San Juan Generating Station in New Mexico, is considering whether to close the remaining two units ahead of schedule. Two units at the Four Corners Power Plant are planned to be retired. Some of these retirements are expected to free up transmission capacity from sites with wind development potential in the Four Corners Region to load centers in the region or in Nevada and California.

Further, PacifiCorp's 2017 integrated resource plan (IRP), which develops a least-cost, least-risk plan to serve the electricity needs of its six-state service territory (including Utah and Wyoming), calls for the retirement of more than 2,700 MW of coal-fired power plants by 2035. New transmission capacity is also being planned. PacifiCorp’s 2017 IRP includes a 140-mile transmission line that will enable more than 1,100 MW of wind. The SunZia Southwest Transmission Project ${ }^{24}$ from New Mexico to Arizona received its federal permits. This transmission line is expected to provide up to 3,000 MW of transfer capacity for wind (and solar) to Arizona with delivery possible to California. The 4CWRC hosted a number of educational webinars $^{25}$ including the topic of transmission and the retirement of the Navajo Generating Station to share knowledge and lessons on the transmission expansion process as well as to share information on transmission capacity that is becoming available through coal unit retirements across the region. Information was shared regarding transmission expansion as well as how local stakeholders can shape the transmission planning process.

The process to develop transmission can often take a decade or more. To identify transmission needs, utilities conduct numerous studies based on a mix of expected resources. WestConnect, the utility-led transmission planning organization for the Four Corners region, initiated a 2-year study in 2016 of two scenarios with higher amounts of wind energy. The first scenario adds about 300 MW of wind energy in Arizona, New Mexico, Nevada, and Colorado. The second scenario is more aggressive, adding 4,895 MW of wind in various locations in those states. The

\footnotetext{
24 http://www.sunzia.net/

25 http://www.fourcornerswind.org/webinars
} 
study results will identify whether there is sufficient transmission capacity to support these resource additions and, if not, where additional transmission is needed.

Lack of local wind siting ordinances or ordinances utilizing best practices. Across the West, counties are the regulatory bodies with jurisdiction over wind projects, yet they are frequently understaffed and do not have deep wind expertise.

The 4CWRC has developed close relationships with county planners and commissioners to provide wind energy information. In 2016-2017, officials in Utah counties were in the process of updating their resource management plans. The 4CWRC supported county officials by developing and providing technical information and wind development language for use in their plans. Through this initiative, 12 counties in Utah included wind resource development information provided by the 4CWRC in their resource management plans.

Varying wind technology costs and outputs. Wind capacity factors vary across the West, and wind competes with low-cost natural gas and utility-scale solar photovoltaic power plants. Nevertheless, wind is increasingly competitive at the utility scale and continues to increase in value as a resource as technology advances and costs decline.

The 4CWRC has worked to deliver information about technological advances (through phone calls, webinars, and fact sheets) to decision makers in the region and to insert up-to-date cost information in regulatory proceedings. The 4CWRC developed state- and county-specific fact sheets ${ }^{26}$ demonstrating the increasing value of wind resources with taller towers and utilizes them in communications with regional stakeholders.

Integration challenges and costs. While the integration of renewables has increased and the level of expertise among utilities and independent system operators has also increased, there is still widespread concern about the costs and challenges of integrating variable generation. As has been proven in many states and countries, integrating $30 \%$ or $40 \%$ (or more) wind is possible. Often the problems with integration are not technical in nature; people and institutions can be barriers.

The 4CWRC has worked with stakeholder groups and hosted webinars ${ }^{27}$ to educate on a range of wind integration topics, and the group also hosts technical resources on its website to share them with decision makers and the interested public. The 4CWRC also includes integration bestpractice information as appropriate in regulatory proceedings.

Misinformation and lack of fact-based information on wind energy's benefits and impacts. Wind energy opponents are active in several states in the region; some of them use misinformation available online to present cases against wind development when projects are in the public meeting stage of permitting.

The 4CWRC has developed relationships with county planners and commissioners in the windy counties of the region and works with them to provide science-based, peer-reviewed research to

${ }^{26}$ http://www.fourcornerswind.org/resources

27 http://www.fourcornerswind.org/webinars 
counter unfounded arguments against wind development. In addition, the 4CWRC works to address general concerns related to wind energy development.

Permitting processes resulting from the presence of wildlife species. Wind development companies in western states typically perform pre-construction monitoring to determine the location of raptor nesting sites or the presence of protected wildlife, as well as the potential patterns of migrating avian and terrestrial wildlife. These pre-construction assessments can be extremely effective at identifying and helping to mitigate wildlife issues in the early stage of development.

The 4CWRC works with federal and state wildlife protection agencies to determine areas of concern and to share the research resources of the American Wind Wildlife Institute to assist with navigating the permitting processes. ${ }^{28}$

Challenges with development on federal land. Developing on federal land requires an understanding of the National Environmental Policy Act process and may be difficult in areas where wind development has not been deemed a community priority.

The 4CWRC worked with each of Utah's 26 counties to ensure that local stakeholders have the information they need to address wind energy development within the scope of their resource management plans. Twelve counties are using 4CWRC language in their plans. More information on these efforts is included in the Utah state section of this report.

Decline in the cost of solar energy. Wind energy has been a low-cost renewable energy resource for many years. However, recent solar energy cost decreases have created competition and affected the amount of wind energy considered by utilities. While some 4CWRC states have excellent wind resources, such as Colorado, others like Arizona, Nevada, and Utah have more competitive, high-quality solar energy resources, and in some cases individual utilities have demonstrated a preference for solar over wind.

\subsection{Collaborating Organizations}

RRCs engage diverse stakeholder groups, disseminate targeted technical information about appropriate wind deployment, and provide forums for constructive dialogue. In addition to credible partners such as universities and state energy offices, RRC leaders identify and engage with strong state champions and include these champions in activities whenever possible. Organizations that have collaborated with the 4CWRC include Advanced Energy Economy; American Wind Energy Association; Arizona Commerce Authority; Arizona State University Energy Policy Innovation Council; Beaver County, Utah; California Independent System Operator; California Natural Resources Agency; Carbon County, Utah; Coconino County, Arizona; Colorado Energy Office; Colorado State University Center for the New Energy Economy; Daggett County, Utah; Distributed Wind Energy Association; Energy Imbalance Market Transitional Committee; Garfield County, Utah; GE Power and Water; Grand County, Utah; Hopi Tribe Renewable Energy Office and Energy and Water Team of Tribal Council; Hualapai Tribe Planning Office; Iberdrola Renewables; Iron County, Utah; Juab County, Utah; Lawrence Berkeley National Laboratory; Lincoln County, Colorado; Millard County, Utah;

${ }^{28}$ https://awwi.org/ 
Navajo Nation Carbon Team and Energy Policy Implementation Task Force; New Mexico Renewable Energy Transmission Authority; NextEra Energy Resource/WindLogics; Paiute County, Utah; San Juan County, Utah; Sevier County, Utah; State of New Mexico Energy, Minerals and Natural Resources Department; State of Utah Office of Energy Development; Summit County Council, Utah; U.S. BLM; Utah Association of Counties and Associations of Governments; Utah County, Utah; WestConnect; Western Area Power Administration; Western Grid Group; and Xcel Energy.

\subsection{State Updates}

The following sections summarize the state of the wind energy industry in each of the states in the 4CWRC region. Note that although the 4CWRC contributes to engagement activities in Wyoming, in this report the state's activities are listed in the Northwest Wind Resource and Action Center's section.

\subsubsection{Arizona}

By the end of 2017, Arizona had 268 MW of installed wind capacity (American Wind Energy Association 2018). In 2016, wind energy development accounted for $\$ 573$ million of total capital investment within the state and supported 500 to 1,000 direct and indirect jobs (American Wind Energy Association 2017a).

Arizona's Renewable Energy Standard and Tariff, or REST, is 15\% by 2025, and utilities in the state are on track to comply with the standard. ${ }^{29}$ A docket is open at the Arizona Corporation Commission to consider doubling the standard to $30 \%$ by $2030 .{ }^{30}$ Wind energy development in Arizona slowed after the state utility RPS goals were fulfilled; contributing factors include BP's exit from renewable energy development and the preference of many utilities, the Hualapai Tribe, Navajo Nation, and Hopi Tribe for solar development over wind due to solar energy's recent cost decreases. Development ceased on a number of wind projects that were well underway with feasibility or pre-construction studies. These include BP's wind project (up to 500 MW), Gray Mountain (500 MW) and Big Boquillas (180 MW) on the Navajo Nation, and Hualapai (170 MW) and Hopi (100 MW) proposed projects. In addition, Foresight Renewables, developers of the fully permitted 40-MW Sunshine Wind Project, elected not to renew the county permit.

Resource assessment is taking place in a number of counties, and developers have discussed project permitting in two eastern Arizona counties (Navajo and Apache). However, there is no indication that projects will be built in the near term. It is unclear whether California's RPS increase, low wind prices, and Arizona Public Service's entry into the energy imbalance market will drive greater Arizona wind development.

The most significant recent event that may foster wind development is the expected closure of the Navajo Generating Station, as potentially 2,000-plus MW of transmission capacity may become available in the wind-rich Four Corners Region. Utilities owning the coal plant will seek

\footnotetext{
${ }^{29}$ Arizona utilities' annual REST compliance plans are available at http://www.azcc.gov/divisions/utilities/electric/environmental.asp

30 See http://edocket.azcc.gov/Docket/DocketDetailSearch?docketId=19621
} 
replacement energy that could be provided by wind projects in the Gray Mountain area. ${ }^{31}$ Personnel at DOE's national laboratories have been contracted by companies and tribal governments to provide information about the wind resource and economic potential for wind development in tribal areas in this region.

Two major transmission projects in advanced stages of development will connect southern Arizona to renewable resources in New Mexico. The proposed SunZia Southwest Transmission Project will include 515 miles of 500-kV lines with a capacity of 3,000 MW (SunZia Southwest Transmission Project 2016). An economic impact assessment prepared by The University of Arizona and New Mexico State University estimated that the SunZia project would support about 6,200 jobs during the 4-year construction period and generate state and local taxes totaling \$25 million in Arizona and \$65 million in New Mexico (Charney et al. 2011). The BLM and Arizona Corporation Commission approved the SunZia Project, and developers expect it to be operational by 2021. Additionally, the proposed Southline Transmission Project will extend and rebuild existing transmission lines with 367 miles of $345-\mathrm{kV}$ line with a rated capacity of 1,000 MW. The BLM and Western Area Power Administration both issued records of decisions that authorize the proposal, and project developers expect to begin construction in 2018.

The 4CWRC is working with the Hopi Tribe on resource assessment activities and providing information for considerations in energy policy development and tribal council education on wind development steps. The 4CWRC also has supported the Hualapai Tribe in pursuing additional wind resource assessment. RRC members also arranged meetings and briefings with Arizona Corporation Commission members to provide wind energy and transmission education.

\section{Transmission Webinar Examines the Opportunity to Repurpose Transmission}

As coal plants around the region begin to retire, there is an opportunity to repurpose existing transmission capacity to support wind energy development. Historically, coal power plants are located far from load, often in areas of significant wind resources. This is the case with Navajo Generating Station.

The 4CWRC determined that information was lacking on the impacts of plant retirement on transmission. The group developed a webinar to address the logistics of who owns transmission related to the Navajo Generating Station and how unused capacity is made available for purchase. The webinar also provided a developer's perspective on the opportunity for renewable energy development.

The webinar on April 25, 2017, was attended by nearly 100 individuals representing developers, local official organizations, utilities, and interested companies. This webinar was the 4CWRC's most popular, providing timely, relevant information about opportunities for near-term wind energy development.

The webinar can be viewed at http://www.fourcornerswind.org/re purposing navajo generation.

\footnotetext{
31 The Gray Mountain area has the best wind profile in Arizona and has been extensively studied.
} 
Published in April 2017, Tucson Electric Power Company's integrated resource plan calls for $800 \mathrm{MW}$ of renewable capacity (solar and wind) to be added to the system between 2023 and $2030 . .^{32}$

As an example of workforce development activities, NAU hosts the Arizona Wind for Schools project, ${ }^{33}$ which has installed 18 wind turbines at schools across the state. The project works with K-12 students to prepare them for wind industry careers and trains teachers to expand wind energy education in the classroom. In April 2017, NAU hosted a KidWind Challenge for 20 middle and high school teams. The teams designed and built wind turbines for competition in a wind tunnel and performed technical interviews with judges from the wind industry to test their knowledge of general wind energy concepts and wind turbine design.

NAU also hosted an undergraduate team for DOE's Collegiate Wind Competitions in 2014 and 2016 and the Collegiate Wind Competition Technical Challenge in 2015 and 2017 and was selected to host a team for the 2018 Competition. ${ }^{34}$ The 2016 team took fourth place at the national competition in May 2016, which was co-located with the American Wind Energy Association's WINDPOWER 2016 Conference \& Exhibition and the National KidWind Challenge. Industry members from XZERES Corporation and Prometheus Renewable/Novakinetics advised the NAU team during the 2015-2016 year, allowing NAU students to tap the experience and expertise of seasoned industry professionals for the development of their wind turbine blades and their business and development plan.

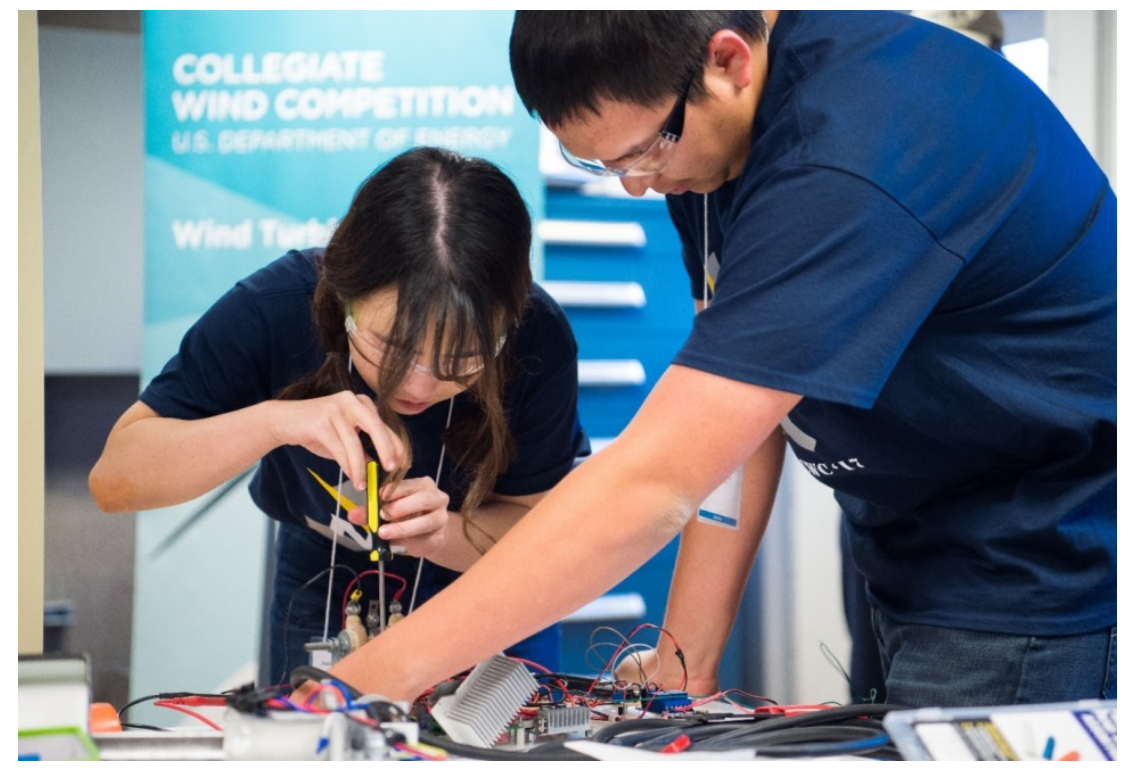

Figure 6. Northern Arizona University students make final adjustments to their turbine components before their wind tunnel testing in the Collegiate Wind Competition 2017 Technical Challenge. The team received an honorable mention for the technical design presentation. Photo by Dennis Schroeder, NREL

\footnotetext{
32 https://www.tep.com/wp-content/uploads/2017/04/TEP-2017-Integrated-Resource.pdf

${ }_{33}$ http://nau.edu/cefns/engineering/mechanical/research-and-labs/energy/education/wind-for-schools/

${ }^{34}$ http://energy.gov/eere/collegiatewindcompetition/downloads/northern-arizona-university-0
} 
At the 2017 Technical Challenge at NREL's National Wind Technology Center, NAU's team took first place for their technical presentation and third place for the technical challenge (including design report and presentation).

\subsubsection{Colorado}

Wind power provided more than 17\% of the electricity generated in Colorado by the end of 2016 (American Wind Industry Association 2017c). By the end of 2017, Colorado had 3,104 MW of utility-scale wind installed (American Wind Industry Association 2018). Nearly 27 MW of distributed wind (U.S. Department of Energy 2017a) were installed by the end of 2016. As of 2016, the wind industry in Colorado provided a total capital investment of \$5.9 billion and supported 6,001 to 7,000 direct and indirect jobs (American Wind Industry Association 2017a). Colorado communities have long benefited from wind developments' contributions to the tax base, which helps to pay for roads, schools, and other critical public projects.

Colorado's RPS has helped to spur wind development in the state and contributes to the current thriving market. The original RPS was established when Colorado voters approved Amendment 37 in 2004, and the legislature has made several adjustments over the years. Investor-owned utilities must meet a 30\% by 2020 renewable standard. Legislation passed during the 2013 session increased the standard for electric co-ops serving 100,000 or more electric meters to $20 \%$ by 2020 and left the standard at $10 \%$ by 2020 for smaller co-ops and municipal utilities.

Two large wind projects totaling 399 MW were completed in Colorado in 2015. Other projects are currently in development, including Xcel Energy’s proposed \$1 billion, 600-MW Rush Creek Wind Project, which would be the state's largest wind farm. Proposed in 2016, the Rush Creek project includes a new 345-kV transmission line with additional capacity for new wind energy beyond this project. The project will incorporate 300 Vestas turbines manufactured in Colorado (Xcel Energy 2016).

Continued low wind energy costs, concerns around emissions, and Public Service Company of Colorado's ongoing improvements in integration and forecasting technology present opportunities for more Colorado wind power, spurring procurement over and above state RPS requirements. The state's largest investor-owned utility, Public Service Company of Colorado, is on track to meet and likely exceed the 30\% RPS and has been aggressive in seeking to acquire low-cost wind energy.

Barriers to increased wind development in Colorado are primarily related to interconnection and transmission constraints. In 2013, Public Service Company of Colorado joined with six other utilities $^{35}$ to study forming a single regional transmission tariff and study the benefits of forming or joining a regional transmission organization. The leading proposal is for the group of utilities to join the Southwestern Power Pool. The group, known as the Mountain West Transmission Group, could provide additional opportunities for Colorado wind as these utilities consolidate their many balancing areas into one of the nation’s largest regional transmission organizations.

\footnotetext{
${ }^{35}$ Signatories to the Mountain West Transmission Group include Public Service Company of Colorado, Western Area Power Administration, Tri-State Generation and Transmission Inc., Platte River Power Authority, Black Hills Corporation, Colorado Springs Utilities, and Basin Electric Power Cooperative.
} 
Being part of a coordinated market could allow easier and more cost-effective integration of wind energy, encouraging smart community development.

Two recent Federal Energy Regulatory Commission rulings between Delta-Montrose Electric Association and Tri-State Generation and Transmission Association, Inc., allow rural electric coops to increase the amount of renewable energy they can purchase and provide to customers. Many co-ops are contractually obligated to purchase a certain percent of their electricity from their generation and transmission power provider. Under its contract, Delta Montrose Electric Association was required to purchase at least 95\% of its power from Tri-State and was limited to owning or purchasing only $5 \%$ from other generation sources. The commission ruled that under the federal Public Utility Regulatory Policy Act, co-ops can purchase power from small renewable energy facilities within their service area, even if those purchases exceed contractual limits. This creates greater opportunity for small renewable energy developers to work with coops in under-served rural areas to increase the amount of clean energy available to consumers.

Colorado has been heavily engaged in wind energy education with university programs at Colorado State University and the Colorado School of Mines. These two educational institutions teamed with NREL and University of Colorado at Boulder to develop the Center for Research and Education in Wind, ${ }^{36}$ a research center under the Colorado Energy Research Collaboratory. ${ }^{37}$ The Colorado School of Mines also participated in DOE's 2014 Collegiate Wind Competition ${ }^{38}$ and Collegiate Wind Competition 2015 Technical Challenge. Colorado also participates in DOE's Wind for Schools project; Colorado State University leads the effort with 13 school systems installed in the state. ${ }^{39}$ The Ecotech Institute in Aurora hosts a wind technician training program.

\subsubsection{Nevada}

Nevada's first (and only) utility-scale wind project, Spring Valley, came online in 2012 near Ely. Spring Valley is a 152-MW project with total capital investment of approximately \$306 million (American Wind Industry Association 2017a) that supports 13 full-time permanent positions for ongoing operations and maintenance (PR Newswire 2012). Although wind developers remain interested in Nevada, no wind projects are under construction there. Additionally, developers for Apex Clean Energy's Searchlight Wind project ceased development efforts in April 2017 after legal setbacks regarding the project’s environmental review process (Brean 2017).

Wind energy developers continue to face competition from the state's strong solar and geothermal resources. In addition, uncertainty associated with the Energy Choice ballot initiative (which, if passed by voters for the second time in 2018, will set Nevada on a course toward deregulation) is expected to delay renewable opportunities. However, NV Energy recently joined the regional energy imbalance market, and California's recent RPS increase could help to create additional opportunities for Nevada wind power throughout the region.

The wind industry and state permitting organizations continue to address challenges regarding wildlife impacts and regulatory processes to ensure limited harm to wildlife species, especially

\footnotetext{
36 http://crew.colorado.edu/

37 http://www.coloradocollaboratory.org/

38 http://energy.gov/eere/collegiatewindcompetition/downloads/colorado-school-mines

39 https://sites.google.com/a/rams.colostate.edu/csu-wac/services
} 
those that are considered threatened or endangered. Species with wind energy impact concerns include golden eagles, Mexican free-tailed bats, and desert tortoises.

An additional challenge related to the expansion of wind energy in Nevada pertains to siting issues on or near federal lands (which comprise 81.1\% of Nevada's total acreage). Although next-generation low-wind-speed technologies allow wind energy to be cost effectively deployed in locations with lower wind resources, the combination of fewer high-resource areas and the abundance of federal land complicate Nevada wind development.

A number of major proposed transmission lines would deliver renewable electricity from states with high wind resources to Nevada and California. The proposed TransWest Express Transmission Project would construct more than 700 miles of 600-kV DC line with 3,000 MW of capacity to carry electricity from Wyoming to southern Nevada. The transmission line is part of the proposed 1,000-turbine Chokecherry and Sierra Madre Wind Energy Project, ${ }^{40}$ both of which are in advanced stages of development in Wyoming. The TransWest proposal has been in development since 2007; it passed major hurdles when the BLM published the Final Environmental Impact Statement in May 2015 and approved the project in December 2016. Developers hope to begin construction between 2018 and 2020 (TransWest Express 2017). This project does not create an opportunity for Nevada wind energy development to export power elsewhere, but it would import power to Nevada load and trading hubs. It is not clear what impacts these transmission projects would have on Nevada's local wind market, but the role of geographic diversity to help defer variability concerns may support more local wind development.

\subsubsection{New Mexico}

New Mexico is home to 1,682 MW of installed wind capacity as of December 2017 (American Wind Energy Association 2018), generating more than 11\% of New Mexico's in-state energy production. To date, wind energy development in New Mexico has created \$2 billion of total capital investment and supported between 1,000 and 2,000 direct and indirect jobs (American Wind Energy Association 2017a). As of September 2017, approximately 1,028 MW of wind capacity were under construction (American Wind Energy Association 2017c).

State utilities are on track to meet a 20\% by 2020 RPS for investor-owned utilities and 10\% by 2020 for rural electric co-ops. In addition to the RPS, the state's renewable energy production tax credit (available for wind, solar, and biomass) has contributed to wind project development in the state. The New Mexico Energy, Minerals \& Natural Resources Department recently commissioned an economic analysis of the state renewable energy production tax credit. ${ }^{41}$ The study indicated that between 2003 and 2012, the state expended \$61.6 million on the production tax credit (of which $\$ 54.2$ million was for wind projects). For these same projects and time period, the study estimates the total labor income impacts to New Mexico’s economy were \$434 million and more than 9,000 jobs, with more than $80 \%$ of the impact coming from wind facilities. The study estimates an additional value of more than $\$ 400$ million of avoided emissions in the state (New Mexico Energy, Minerals \& Natural Resources Department 2015).

\footnotetext{
${ }^{40}$ http://www.powercompanyofwyoming.com/

41 The report is available at

http://www.emnrd.state.nm.us/ECMD/CleanEnergyTaxIncentives/documents/REPTCFinalReportFeb2015.pdf
} 
The tax credit is scheduled to expire at the end of 2017; legislative attempts to extend it have not succeeded, due in large part to the state's fiscal situation. The latest extension effort (HB 440 and SB 432) failed in the Legislature in March 2017 (Moss 2017).

New Mexico’s relatively slow economic recovery from the global recession combined with a small, rural population present challenges for finding in-state markets for new wind development. In addition, utilities serving New Mexico customers have often selected solar PV in relatively small megawatt procurements for RPS compliance. New Mexico's state utilities and the Public Regulation Commission have not demonstrated a willingness to consider beyond-RPS renewable energy purchases. The stipulated agreement regarding the retirement of two coal-fired units at San Juan Generating Station, approved by the New Mexico Public Regulation Commission in December 2015, calls for a small percentage of new solar energy and no additional wind energy, but it paves the way for reconsideration of the future of the remaining two units in the near term (starting in 2018). Should those remaining two units retire (as is expected), there could be more significant opportunities for wind energy as replacement power.

The most significant opportunities for New Mexico wind are likely in western markets beyond its borders. While there are transmission constraints for exports, several major projects are underway, including the SunZia Southwest Transmission Project, Southline, and Western Spirit. Both the SunZia and Southline projects are in advanced stages of development. The proposed SunZia Southwest Transmission Project will include 515 miles of 500-kV lines with a capacity of 3,000 MW (SunZia Southwest Transmission Project 2016). An economic impact assessment prepared by The University of Arizona and New Mexico State University estimated that the SunZia project would support about 6,200 jobs during the 4-year construction period and generate state and local taxes totaling \$25 million in Arizona and \$65 million in New Mexico (Charney et al. 2011). The BLM and Arizona Corporation Commission approved the SunZia Project, and developers expect it to be operational by 2021. Additionally, the proposed Southline Transmission Project will extend and rebuild existing transmission lines with 367 miles of 345$\mathrm{kV}$ line with a rated capacity of 1,000 MW. The BLM and Western Area Power Administration have both issued records of decisions that authorize the proposal, and project developers expect to begin construction in 2018.

Regarding wind energy education and workforce development, the Southwest Technology Development Institute based at New Mexico State University has a long history of outreach and development work focusing on distributed wind technologies. Mesalands Community College in Tucumcari has a wind technician training program.

\subsubsection{Utah}

As of the end of 2017, Utah had 391 MW of installed capacity (American Wind Energy Association 2018) providing about $2 \%$ of the electricity generated in the state. The industry provided approximately $\$ 850$ million of total capital investment in the state and supports between 101 and 500 direct and indirect jobs (American Wind Energy Association 2017a).

The 62-MW Latigo Wind Park (Figure 7) came online in March 2016. The Latigo Wind Park is the largest private investment on private land in San Juan County history, and it will contribute millions in tax revenues to the rural county over the life of the project (sPower 2016). 


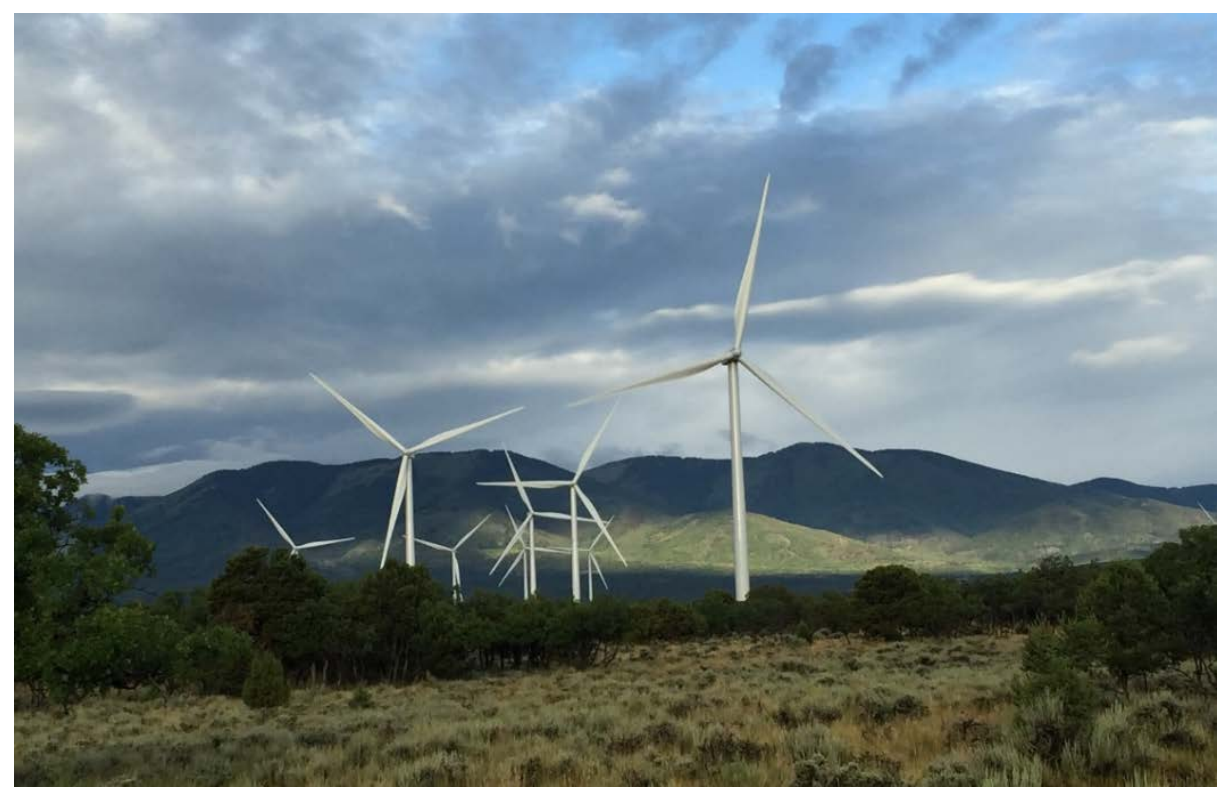

Figure 7. The Latigo Wind Park in Utah provides benefits to a rural county with limited development opportunities. Photo from sPower

Challenges to wind development in Utah include the lack of available transmission capacity, issues siting on or near federal lands that comprise 66.5\% of Utah's total acreage (Congressional Research Service 2014), lack of wind siting ordinances, developer efforts focused on solar prior to the scheduled reduction of the federal investment tax credit for solar, and integration challenges (including costs).

The 4CWRC is working to address many of these challenges. For instance, the 4CWRC worked with officials in each of the Utah counties to encourage the inclusion of language supporting wind development on federal land in the counties' required resource management plan documents. Under the Federal Land Policy and Management Act, ${ }^{42}$ the inclusion of this language in the counties' management plans has the potential to impact federal land management decisions, including the siting and development of renewable energy. Twelve Utah counties ultimately included 4CWRC language in their plans.

Rocky Mountain Power (a subsidiary of PacifiCorp) is Utah's investor-owned utility that serves the majority of the population in the state. In 2015, Rocky Mountain Power filed an application to reduce the contract term for Public Utility Regulatory Policy Act power purchase agreements with qualifying facilities from 20 to 3 years. ${ }^{43}$ Similar efforts have been made in other states (Idaho, Oregon, and Wyoming) with varying success. In Utah, the Public Service Commission declined to reduce the contract term to 3 years but instead reduced the allowable term to 15 years. It is unclear how the 15-year term will impact future wind energy development in the state or whether Rocky Mountain Power will seek further reductions in the contract term.

PacifiCorp joined the regional energy imbalance market and is exploring the possibility of joining the California Independent System Operator (CAISO). By joining the regional energy

\footnotetext{
${ }^{42}$ http://www.blm.gov/flpma/

${ }_{43}$ Utah Public Service Commission Docket Number 15-035-53, available at http://www.psc.utah.gov/utilities/electric/elecindx/2015/1503553indx.html
} 
imbalance market, PacifiCorp has facilitated cost-effective integration of renewable energy that is already providing significant savings to utility customers. Joining the larger regional market through CAISO will create additional opportunities for wind power development throughout the region. 


\section{Islanded System Region}

Colleagues from the Islanded Grid Resource Center (IGRC) and the National Renewable Energy Laboratory (NREL) collaborated to provide the following assessment of the state of the wind industry in this region.

Interested parties of the IGRC ${ }^{44}$ are in Alaska, Maine, Massachusetts, Rhode Island, ${ }^{45}$ Hawaii, Guam, American Samoa, Commonwealth of the Northern Mariana Islands (CNMI), Puerto Rico, and U.S. Virgin Islands. The three focus areas of the Regional Resource Center (RRC) are winddiesel systems, megawatt-scale systems on islanded grids, and support for island communities near proposed commercial-scale offshore wind and other ocean energy projects. Due to the nature of islanded grid systems, the IGRC faces unique challenges.

Although located on opposite sides of the country and not linked geographically, islanded grid communities share common challenges and opportunities for wind development. Most have small populations with limited human capacity and sub-optimal infrastructure. Transportation and distribution costs tend to be higher than in other parts of the country, exacerbating financing challenges. Many of these communities have severe climates and/or are being impacted by climate change and rising sea levels (U.S. Department of Energy 2015a, U.S. Department of Energy 2015c). Most rely on expensive diesel fuel (subject to volatile price swings) to generate electricity and therefore share technical difficulties associated with wind integration. Reliance on diesel fuel comes with a host of environmental concerns, including meeting emissions standards, the need for bulk fuel storage, and the potential for fuel spills. However, many islanded grid communities have excellent wind resources (and other renewable energy resources), with some near proposed offshore wind projects.

Because islanded communities are often remote and geographically distant, many of these jurisdictions have not traditionally communicated with each other about progress related to wind energy implementation. Also, stakeholders from islands and islanded regions have typically had few options for technical support. These regions cannot look to wind development on large-scale grid systems as models, and with limited funding and resources, they have limited ability to perform testing and development work on their own. However, the number of resources for these communities is growing as more entities become interested in the technologies and development of remote islanded grids and microgrid systems. In addition to the IGRC, these interested entities include the United Nations' Sustainable Energy for All initiative; ${ }^{46}$ SIDS DOCK, an energy initiative of the Alliance of Small Island States; ${ }^{47}$ the Rocky Mountain Institute's Islands Energy Program, ${ }^{48}$ the U.S. Department of Energy's (DOE's) Energy Transition Initiative; ${ }^{49}$ the Clinton Foundation's Islands Energy Program; ${ }^{50}$ and NREL's team of experts that manages the Renewable Energy Planning and Optimization (REopt) energy planning platform. ${ }^{51}$

\footnotetext{
${ }^{44}$ http://islandedgrid.org/

${ }_{45}$ Maine, Massachusetts, and Rhode Island are also part of the Northeast Wind Resource Center region.

${ }^{46}$ http://www.se4all.org/

${ }^{47}$ http://sidsdock.org/

${ }^{48}$ https://rmi.org/our-work/global-energy-transitions/islands-energy-program/

${ }^{49} \mathrm{http}$ ://energy.gov/eere/technology-to-market/energy-transition-initiative

${ }^{50}$ https://www.clintonfoundation.org/our-work/clinton-climate-initiative/programs/islands-energy-program

${ }^{51}$ http://www.nrel.gov/tech_deployment/tools reopt.html
} 
As wind systems continue to operate and new systems are installed, a growing database of lessons learned and success stories is available for those developing or installing new systems. For example, the Unalakleet Valley Electric Cooperative in Alaska recently shared that as of November 2016, it had generated its seven-millionth kilowatt-hour (kWh) of power from a 600$\mathrm{kW}$ wind farm installed in 2009 in the remote coastal community of Unalakleet. By using wind energy, the utility reduced its diesel fuel use by 70,000 gallons annually and reduced a fuel surcharge for its customers to 15 cents/kWh; without the wind power, the surcharge would be nearly double, at 26 cents/kWh. In addition, the utility channels excess wind energy to a boiler that provides heat through a loop to community buildings, which serves the dual purpose of helping stabilize the grid and reduce heating costs. Utility representatives have shared their wind integration experiences at various IGRC events. The utility also continues to explore ways to optimize its system, including adding energy storage to more fully utilize the available wind resource, which is currently curtailed up to one-third of the time.

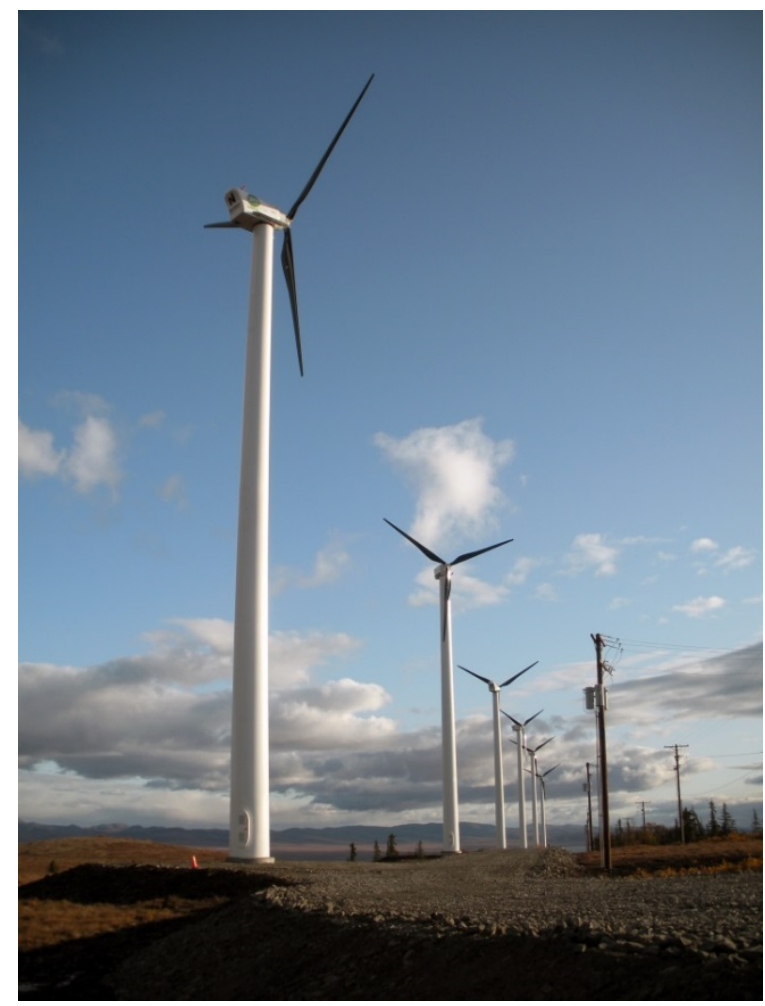

Figure 8. Unalakleet Valley Electric Cooperative installed six Northwind 100 turbines in November 2009. As of November 2016, the wind farm had generated 7 million kilowatt-hours of power and reduced fuel use in the remote Alaskan community by 70,000 gallons annually. Photo by STG Incorporated, NREL 16797

The Unalakleet system is just one of more than 25 wind-diesel hybrid systems in Alaska that are operating in communities with fewer than 1,000 people without energy storage, and the IGRC is working with the Alaska Energy Authority to develop case studies of those projects. Over the past 3 years, the IGRC has helped connect operators in places like Unalakleet with others working on remote grids to build a network of islanded grids to share credible information about 
wind power and other energy solutions. Through events such as the Island Energy Conference; ${ }^{52}$ the Islanded Grid Wind Power Workshop; ${ }^{53}$ the Alaska Wind-Diesel Workshop; the annual exchange trip for New England operators; ${ }^{54}$ and the Cemai Energy Summit Workshop in Bethel, Alaska, ${ }^{55}$ over the past year the IGRC continued to build a strong cohort of islanded grid power system operators, technical experts, community leaders, and industry partners who share effective strategies to facilitate the development of energy solutions in isolated communities from Maine to Guam.

\subsection{Overview of Regional Wind Market}

The following section provides an overview of key wind industry statistics in the IGRC region.

Table 6. Key Statistics for the Islanded Grid Resource Center Region

\begin{tabular}{|c|c|c|c|c|c|c|c|}
\hline & Alaska & CNMI & Guam & Hawaii & $\begin{array}{l}\text { NE } \\
\text { Islands }{ }^{56}\end{array}$ & $\begin{array}{l}\text { Puerto } \\
\text { Rico }\end{array}$ & USVI \\
\hline $\begin{array}{l}\text { Installed Wind (MW), } \\
\text { End of } 4 \mathrm{Q} 17^{57}\end{array}$ & 62 & $\geq .1^{58}$ & .005 & 206 & 4.5 & 125 & 0 \\
\hline $\begin{array}{l}\text { Proposed Offshore } \\
\text { Wind Projects (MW), } \\
\text { as of End of } 2016^{59}\end{array}$ & 0 & 0 & 0 & 1,200 & $970^{60}$ & 0 & 0 \\
\hline
\end{tabular}

Sources: American Wind Energy Association, NREL, U.S. DOE

\subsubsection{Renewable Portfolio Standards}

Alaska does not have a Renewable Portfolio Standard (RPS). In the 2009-2010 legislative session, the Alaska legislature enacted House Bill $306^{61}$ with the goal that "the state receive $50 \%$ of its electrical generation from renewable energy sources by 2025.” Hawaii enacted an RPS in 2001 and includes wind as an eligible technology in its standard, and in 2014 it became the first state in the nation to enact a 100\% (by 2045) renewable energy goal. Applicable sectors are investor-owned utilities and rural electric cooperatives. Of the territories covered by this RRC, only the CNMI has an RPS. The U.S. Virgin Islands, Guam, and American Samoa have renewable targets. Of course, wind deployment on islands located in the Northeast would contribute to RPS goals in those states.

\footnotetext{
52 http://www.islandinstitute.org/resource/2017-island-energy-conference

${ }^{53}$ www.islandedgrid.org/may-6-2016-islanded-grid-wind-power-workshop/

54 http://islandedgrid.org/13522-2/

55 http://islandedgrid.org/april-2017-cemai-energy-summit-workshop-in-bethel-alaska/

56 The Northeast islands are located off New Hampshire, Maine, Massachusetts, and Rhode Island.

${ }^{57}$ American Wind Energy Association 2018

${ }^{58}$ As of June 2015: http://www.nrel.gov/docs/fy15osti/64293.pdf

59 American Wind Energy Association 2017b

$60970 \mathrm{MW}$ is a conservative scenario; whether a project powers coastal New England or islanded New England is not well defined.

${ }^{61}$ http://www.legis.state.ak.us/basis/get_bill_text.asp?hsid=HB0306A\&session=26
} 
Table 7. RPS Overview for States and Territories Served by the Islanded Grid Resource Center

\begin{tabular}{ll}
\hline & RPS \\
\hline Alaska & Target: $50 \%$ of electrical generation by 2025 \\
\hline American Samoa & $\begin{array}{l}\text { Target: } 50 \% \text { of electrical generation by } 2025 \text { and } 100 \% \text { by } \\
2040\end{array}$ \\
\hline Guam & $\begin{array}{l}\text { Target: } 8 \% \text { of net electricity sales from renewables by } 2020 \\
\text { and } 25 \% \text { of sales by } 2035\end{array}$ \\
\hline Hawaii & $30 \%$ of net electricity sales by $2020 / 100 \%$ of sales by 2045 \\
CNMI & $20 \%$ of net electricity sales by 2016 \\
\hline Puerto Rico & $20 \%$ by 2035 \\
\hline & $\begin{array}{l}\text { Targets: } 25 \% \text { by } 2020 ; 30 \% \text { by } 2025 ; 30 \% \text { by } 2025 ; \text { increasing } \\
\text { until } 51 \% \text { of generating capacity is derived from renewable or } \\
\text { alternative energy }\end{array}$ \\
\hline U.S. Virgin Islands &
\end{tabular}

\subsubsection{Communities with $100 \%$ Renewable Energy Commitments}

Many state public utility commissions are working with utilities to choose the direction of their energy portfolios. While some states have mandated and voluntary renewable energy goals or standards, some cities have taken an additional step to create their own commitments to clean energy, some of which exceed levels established by their states. One community within the Islanded Grid Region has made a 100\% renewable energy commitment.

Table 8. Community Served by the Islanded Grid Regional Resource Center with $100 \%$ Renewable Energy Commitments

Source: Sierra Club

\begin{tabular}{lll}
\hline City & State & Target Year \\
\hline Kodiak Island & AK & Achieved in 2012 \\
\hline
\end{tabular}

\subsection{Workforce Development}

Remote locations and small populations make workforce development an ongoing challenge for islanded grids. In Alaska, many remote communities may only have a few people in town who each have several jobs. Many of these communities are also plagued with socioeconomic difficulties, which make it challenging to cultivate and train local talent to operate and maintain community power systems. The Renewable Energy Alaska Project is working across the state to educate teachers about energy curricula and build a new network among those educators, vocational and technical training centers, and university programs. Called the Alaska Network for Energy Education and Employment, ${ }^{62}$ the organization's goal is to create seamless career paths for energy professionals and operators in the state. The Renewable Energy Alaska Project is also working with a variety of other stakeholders to find ways to increase human capacity in

\footnotetext{
${ }^{62}$ http://alaskarenewableenergy.org/website2016/index.php/programs/education/ak-network-for-energy-educationand-employment/
} 
small villages to enhance the viability of the long-term operation and maintenance of wind systems in Alaska.

Alaska's Institute of Technology ${ }^{63}$ supports technical curricula associated with the operation and maintenance of wind energy as part of its remote power system technician training curricula, supporting wind development in remote and islanded communities. Another entity at the center of this effort is the Power Systems Integration Laboratory ${ }^{64}$ (formerly the Alaska Wind-Diesel Wind Application Center) operated by the Alaska Center for Energy and Power at the University of Alaska Fairbanks campus. The laboratory develops and maintains research facilities that allow testing of new technologies that could be integrated into wind-diesel systems.

The University of Alaska Fairbanks hosted an undergraduate team for DOE's Collegiate Wind Competition 2014 and 2016 and placed third in the 2017 Collegiate Wind Competition Technical Challenge. The Universidad del Turabo in Puerto Rico hosted an undergraduate team for the Collegiate Wind Competition 2016 and was selected to participate in Collegiate Wind Competition 2018.

The University of Alaska Fairbanks, in collaboration with the Renewable Energy Alaska Project, also supports a state Wind for Schools effort; see the map below for the locations of other school projects. The WINDExchange website offers information and interactive maps regarding workforce development, the DOE Collegiate Wind Competition, DOE's Wind for Schools project, school wind project locations, and locations of education and training programs in the Islanded Grid region and other states. ${ }^{65}$

In addition, the Island Institute's annual New England exchange trip is an example of a capacitybuilding and professional development opportunity for employees of island power companies and local energy leaders. In 2017, the trip included a visit to Block Island that engaged energy leaders from Monhegan, Maine; Martha’s Vineyard, Massachusetts; Nantucket, Massachusetts; and Block Island, Rhode Island. (More information on the Block Island trip is presented later in this section.)

\footnotetext{
${ }^{63}$ https://www.avtec.edu/

${ }^{64}$ http://acep.uaf.edu/facilities/power-systems-integration-lab.aspx

65 https://windexchange.energy.gov/education-workforce
} 


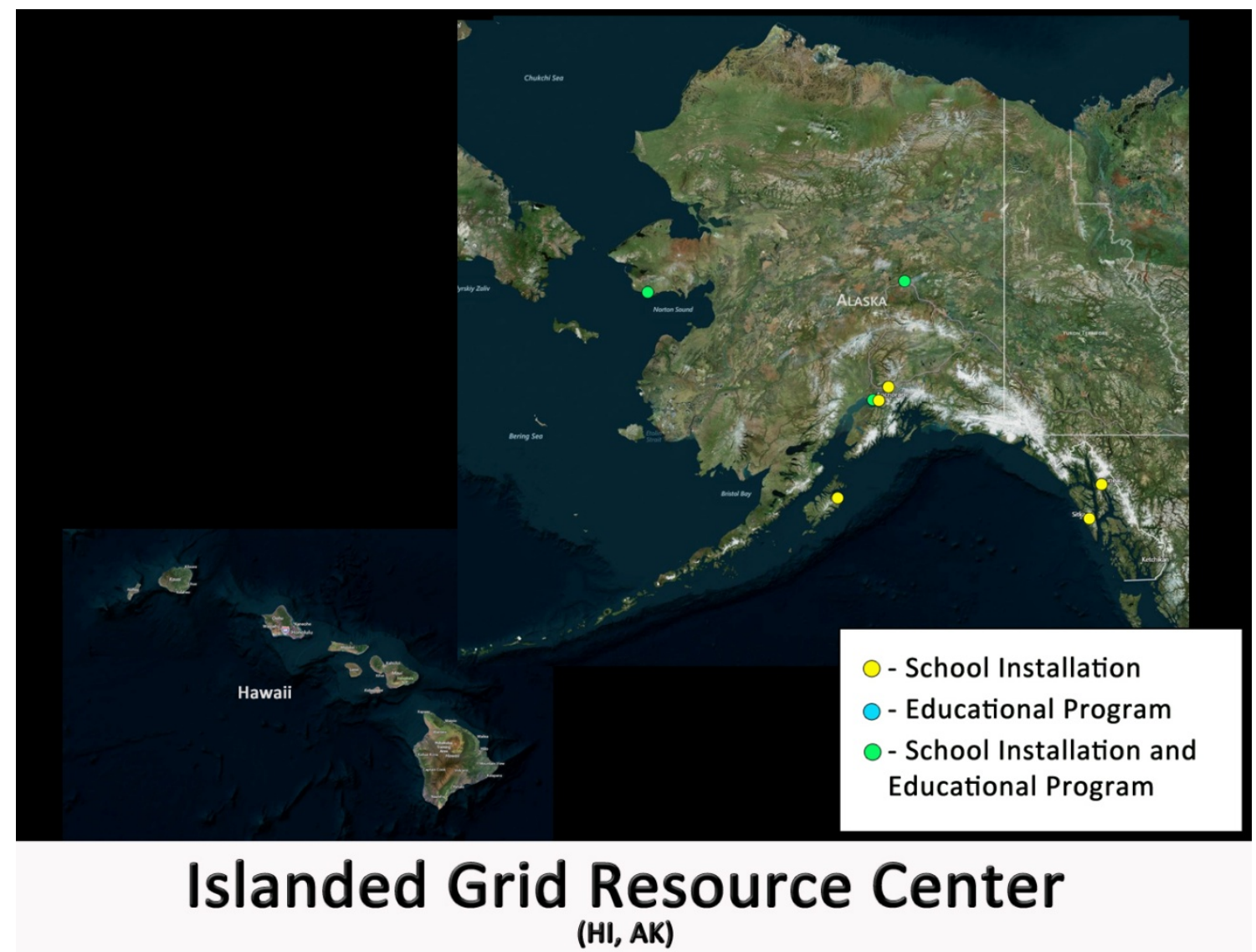

Figure 9. Map of school wind turbine projects, educational programs, and locations with both wind turbines and educational programs within the Islanded Grid Resource Center's area

\subsection{Manufacturing and Economic Development}

There is no wind-related manufacturing in the IGRC region. However, there has been increasing interest in Alaska in using renewable energy resources for processing minerals. In 2017, the Renewable Energy Alaska Project was approached for information by a mining company that expressed an interest in locating a processing facility using renewable electricity in the state's Railbelt region.

Economic impacts from wind development in the islanded grid region include the capital investment, jobs supported, tax revenues paid, payments in lieu of taxes, and land lease payments made by wind developers during construction and the ongoing maintenance of wind plants. The American Wind Energy Association performs modeling work that identifies the impacts of all wind-related investment. Table 9 summarizes the total jobs (including construction jobs in 2016) and capital investment over time in wind farms in the IGRC states. Examples of economic impacts are provided in each of the state overviews below. Sufficient data are currently unavailable for island entities, other than jobs data in Puerto Rico. 
Table 9. Economic Impacts of Wind Development in States Served by the Islanded Grid Resource Center

\begin{tabular}{lll}
\hline State & Direct and Indirect Jobs Supported & Total Capital Investment \\
\hline Alaska & $1-100$ & $\$ 126$ million \\
Hawaii & $101-500$ & $\$ 407$ million \\
\hline Puerto Rico & $1-100$ & Not available \\
\hline
\end{tabular}

Source: American Wind Energy Association 2017a, as of 2016

\subsection{Key Stakeholder Groups and Development Challenges}

The IGRC targets these stakeholder groups:

- Utilities and operators of islanded power systems

- Researchers and technical experts

- Trade associations and non-profits

- Military

- Policymakers, elected and non-elected

- Manufacturers and supply chain businesses

- General public.

The information provided to these stakeholder groups addresses the following wind energy development market barriers that are prevalent in this region. Each barrier is followed by a more detailed description specific to the Islanded Grid region and an example of the IGRC's work to address the barrier with their stakeholders.

The upfront cost of deploying a sophisticated wind-diesel system in a remote area with limited technical and human capacity is steep. Since most of these grids are off the road system, transportation and mobilization costs are much higher than they are for communities in other regions on the road system. Another challenging cost driver is the small scale of the projects, with many communities having a load of less than 300 kilowatts. The systems are also quite complicated; efficient integration of wind electrons onto a diesel grid remains one the biggest challenges facing small remote grids. The IGRC provides information on technical barriers, including control systems, secondary load control, and the use of energy storage.

The IGRC has worked with utility operators, policymakers, researchers, and partner affiliate organizations to promote the sharing of technical expertise and financial options through inperson contacts, meetings, events, webinars, and other means such as posting personal and project profiles on the IGRC website ${ }^{66}$ that highlight current information on islanded grid projects and allow operators and others separated by time zones and geography to connect with each other to share information about solutions and lessons learned. IGRC events such as the Island Energy Conference ${ }^{67}$ also address cost by connecting existing system operators (such as those in Alaska) with others outside Alaska to share information about their own projects and strategies for addressing the challenges associated with deploying renewable energy systems in

\footnotetext{
${ }^{66}$ www.islandedgrid.org

67 http://www.islandinstitute.org/resource/2017-island-energy-conference
} 
remote locations. Recent efforts have focused on protecting the $\$ 950$ million Power Cost Equalization endowment, a fund that offsets high energy costs in remote areas of the state, from being used to offset state budget shortfalls as originally proposed in Senate Bill 196. The final legislation preserved the endowment and included provisions for excess earnings to be placed in the state's Renewable Energy Fund.

Through the work of the Island Institute, the IGRC is also working to connect island communities with technical assistance through its Energy Planning for Island Communities initiative. ${ }^{68}$ With technical assistance from DOE's Energy Transition Initiative and NREL's REopt $^{69}$ team, the Energy Planning for Island Communities initiative is helping officials on the islands of Monhegan and Isle au Haut to assess their options for integrating renewable energy, including wind, and energy storage into their island grids; identify the most cost-effective and technically viable solutions for their communities; and develop action plans for the implementation of cost-effective solutions with input from community stakeholders.

Through the Renewable Energy Alaska Project, the IGRC is working to build a network among K-12 energy education, related university programs, and clean energy workforce development in Alaska. In addition to its Wind for Schools and other K-12 energy education efforts, in 2016 the Renewable Energy Alaska Project received 3-year funding from the Office of Naval Research to launch the Alaska Network for Energy Education and Employment. Besides increasing overall energy literacy in Alaska and creating clean energy career paths for young people, a prime objective of the network is to improve and expand workforce training in Alaska that supports wind and wind-diesel applications, especially in the state's small, isolated grids. To that end, the Alaska Network for Energy Education and Employment is working to identify and catalog gaps in training opportunities. Examples of such gaps are a lack of training for rural utility managers for rate setting and saving enough reserves for O\&M; training for power plant operators to troubleshoot and develop skills beyond basic maintenance; and increasing basic math skills (arithmetic and algebra) for individuals wanting to advance in power plant/diesel generator training.

Local utilities are hesitant to consider large-scale wind development. In the larger islanded grid markets, such as the islanded Railbelt transmission system ${ }^{70}$ in Alaska and the islanded power systems in Guam, the CNMI, American Samoa, and the USVI, many of the concerns revolve around wind energy integration, but issues regarding local capacity, complicated siting challenges, and perceived or real concerns regarding wind development also influence decision making. Although wind energy likely provides one of the best near-term options to significantly reduce the use of imported fuels for power generation, utilities and governments often continue to defer considering wind development in place of smaller-scale solar projects.

In Alaska, the IGRC has worked for several years to educate a variety of stakeholders and decision makers on the benefits of a single system operator in a region that now has six utilities operating independently in their own relatively small geography. Besides the economic benefits to consumers from region-wide economic dispatch, the IGRC points out that the expanded

\footnotetext{
68 http://www.islandinstitute.org/energy-planning-island-communities

69 https://reopt.nrel.gov/

${ }^{70}$ A small, isolated transmission system in Alaska that covers the main population centers of the state along the main railroad line including the Seward, the Kenai, Anchorage, Wasilla, and north to Fairbanks
} 
"balancing area" that would come with a single operator would make it much easier to integrate variable renewable energy resources like wind. The IGRC is also working to ensure that integrated region-wide resource planning becomes the norm, rather than the present practice of each utility making new generation decisions independent of adjacent utilities that share an interconnected grid. To ensure a level playing field for wind energy, the IGRC is educating decision makers and the media on the benefits of a universal transmission tariff, regulated integration costs, and avoided cost calculations that are made consistently and transparently. Work on this issue includes meeting with utility leaders, giving testimony to the state legislature, meeting with the governor and his staff, and submitting written and oral public testimony to the Regulatory Commission of Alaska.

Progress over the past year has included the formation of a power pool that will allow three Anchorage utilities to share generation resources resulting in maximized efficiencies in the area. The three utilities serve approximately $75 \%$ of the entire region's load. The agreement will greatly expand balancing and dispatch capabilities and should facilitate the integration of more variable renewable energy, such as wind energy, into the Railbelt grid. This includes the proposed Fire Island II wind farm, for which power purchase agreement negotiations are ongoing. The action is expected to save utilities between $\$ 12$ million and \$16 million each year (Zak 2017).

Some progress has been made toward establishing a system operator governance structure that will include clean energy stakeholders. The Renewable Energy Alaska Project continues to engage with the utilities on the issue of how a future system operator would be governed and what its functions would be, and the regulatory commission recently required updated reports on the progress of those voluntary efforts.

\section{Knowledge of best practices for community-developer engagement around proposed} offshore wind projects is limited. New England island communities are geographically located at the forefront of the emerging offshore wind industry in the United States. As seen in landbased wind projects, the reaction of host communities to a proposed project is heavily influenced by the developer's stakeholder engagement efforts. Many small New England island communities have little technical expertise on energy. Their economies are often based on marine resources and tourism. All of these characteristics, combined with larger seasonal populations that may only engage in local issues at certain times of the year, can create unique challenges for local leaders and utilities and offshore wind developers to navigate. Poorly implemented engagement efforts can lead to low levels of acceptance for a project, thus creating significant barriers to development.

With the installation and completion in 2016 of the Block Island Wind Farm, the nation's first installed offshore wind project, many are looking to the Block Island project for lessons learned on topics ranging from installation to community engagement. The IGRC has developed a strong network of New England island leaders and offshore wind developers by providing them with opportunities for in-person and peer-to-peer information exchange in their own communities. As mentioned earlier in this section, the Island Institute's annual exchange trips and the Island Energy Conference have created important opportunities for these stakeholders (who are actively shaping the future of offshore wind in the region) to connect and learn from each other. The Island Institute's research into best practices for engagement, including community benefit 
agreements, is also enabling the IGRC to document the lessons learned in New England and elsewhere and to share it with a broader audience interested in offshore wind development and ocean planning via a comprehensive report and related webinars, conference presentations, and blog posts. Recently, the findings of this research were published in Energy Research and Social Science, a peer reviewed international journal that examines the relationship between energy systems and society. ${ }^{71}$

\subsection{Collaborating Organizations}

RRCs engage diverse stakeholder groups, disseminate targeted technical information about appropriate wind deployment, and provide forums for constructive dialogue. In addition to credible partners such as universities and state energy offices, RRC leaders identify and engage with strong state champions and include these champions in activities whenever possible. Organizations that have collaborated with the IGRC include Alaska Center for Energy and Power; Alaska Congressional Delegation; Alaska Energy Authority; Alaska Federation of Natives; Alaska Power and Telephone Company; Alaska Village Electric Cooperative; American Samoa Power Authority; American Wind Energy Association; Bergey Windpower; Chugach Electric Association; College of the Atlantic; Commonwealth Utilities Corporation (CNMI); Cook Inlet Region Inc.; Cuttyhunk Electric Light Association; Distributed Wind Energy Association; Endurance Wind Power; Environmental and Energy Technology Council of Maine; EWT; Fox Islands Electric Cooperative; Guam Power Authority; Hawaii Natural Energy Institute; HOMER Energy; Isle au Haut Electric Power Company; Kodiak Electric Association; Kotzebue Electric Association; Maine Congressional Delegation; Maine Governor's Energy Office; Maine Office of the Public Advocate; Maine Public Utilities Commission; Marsh Creek LLC; Matinicus Plantation Electric Company; Matinicus Isle Plantation; Monhegan Plantation Power District; Naushon Trust; Navigant Consulting; Northern Power Systems; Ocean Renewable Power Company; Rocky Mountain Institute; Samsø Energy Academy; Sgurr Energy; Shoals Marine Laboratory; Solar Electric Light Fund; Star Island Corporation; State of Alaska; Sustainable Molokai; Tanana Chiefs Conference; TechnoCentre éolien; TDX Power; Town of Nantucket; Town of New Shoreham; University of Alaska Anchorage Institute of Social \& Economic Research; University of Maine; University of Massachusetts; U.S. Coast Guard; U.S. Virgin Islands Energy Office; U.S. Department of Agriculture Rural Development; Utility Variable-Generation Integration Group; and Vineyard Power.

${ }^{71}$ http://www.sciencedirect.com/science/article/pii/S2214629617301172 


\section{Exchange Trip Connects Local Leaders to Share Information about Community Benefits and Engagement in Offshore Wind}

With offshore wind advances on the horizon, island residents and energy leaders from Monhegan, Maine, and Nantucket and Martha's Vineyard, Massachusetts, traveled to Block Island in March 2017 with the Islanded Grid Resource Center (IGRC) and representatives from the University of Maine's Aqua Ventus I project to meet with local stakeholders and expand an ongoing dialogue among all four island communities.

Suzanne MacDonald, community energy director at the Island Institute and an IGRC representative, assists officials from these remote New England communities in their efforts to learn more about wind energy, including offshore wind projects.

"Working with island communities, I think they often see themselves as pretty unique because they don't have a really big peer group of other communities that face what they face. But when we get them together into this type of setting, they see that they have more in common than they might have realized," MacDonald said.

Island communities face the offshore wind challenge of negotiating community benefit agreements, an experience that Block Island officials and participants discussed during the exchange trip. Community benefit agreements can help ensure that those most affected by the installation of offshore wind farms are compensated by developers for the project's associated impacts. Block Island officials were able to negotiate an agreement that benefited their once-isolated community that was historically powered entirely by diesel generators. By connecting to the regional electric grid, the transition will stabilize and likely reduce electric rates on the island.

According to Nantucket's Energy Coordinator Lauren Sinatra, who participated in the trip, officials in her community wish to negotiate a deal with offshore wind companies to compensate the community for potential impacts while addressing Nantucket's needs.

Block Island town officials negotiated an agreement for developer Deepwater Wind to reimburse the town for consultant fees so that the community could be more adequately represented and informed in the regulatory process and in negotiations with Deepwater. This model is currently being used on Monhegan, an islanded grid community that is disconnected from mainland power, and may be utilized by additional island communities.

The group also visited the Block Island Power Company to learn about the process of connecting the island to the grid. Monhegan recently experienced electric rates exceeding 70 cents per kilowatt-hour, nearly four times the mainland average. When they visited Block Island, Monhegan representatives were considering what form of community benefit agreement to move forward with regarding the proposed 12-megawatt New England Aqua Ventus I project.

The Island Institute published a "What Works" entry about offshore wind on its website that includes a short video about the trip to Block Island (http://www.islandinstitute.org/what-

works/engaging-island-communities-offshore-wind). 


\subsection{State and Territory Updates}

\subsubsection{Alaska}

Alaska has two distinct markets for wind development: larger communities that are connected by the Railbelt and rural communities that are completely remote. As of the end of 2017, Alaska had 62 megawatts (MW) of installed wind capacity providing $3 \%$ of the electricity generated in the state (American Wind Energy Association 2018, 2017c). The wind industry provides more than \$130 million of total capital investment in the state and supports fewer than 100 direct and indirect jobs (American Wind Energy Association 2016a).

Barriers to wind development in Alaska continue to be cost and technically complicated systems. The IGRC shares information through workshops and meetings on technical barriers such as control systems, secondary load control, and the use of energy storage. Other barriers include limited technical training; support and human capacity-building for remote communities; limited financing; misalignment of the state's Power Cost Equalization fuel subsidy and incentives to decrease diesel usage; complicated foundation technology (due to areas of permafrost); high construction and logistics costs; and lack of understanding of the long-term benefits and applicability of wind technology to reduce usage of imported fuel options.

Since 2013, the state has experienced budget shortfalls partially due to low oil prices that have affected the state's revenue (Respaut 2017). As a result, Alaska's Renewable Energy Fund, the state's primary renewable energy driver, experienced major funding cuts by the state legislature. The legislature has not appropriated any new money for the fund since 2015. However, a few wind and wind-related projects continue to move forward. Alaska Village Electric Cooperative is adding a 900-kW EWT turbine in St. Mary's/Pitkas Point and in Bethel, Alaska. Alaska Village Electric Cooperative is looking for a new site for the Bethel turbine as the initial location for the project; the Federal Aviation Administration denied approval in August 2017 due to potential impacts to navigational air space conditions (MacArthur 2017). Kotzebue Electric Association is adding solar to its existing wind-diesel system, which also includes battery storage. Anchoragebased Chugach Electric Association, which serves the Railbelt, ${ }^{72}$ is adding a 1-MW flywheel and a 2-MW Samsung battery system that could assist in adding more wind to the Railbelt system.

Because of the previously mentioned budget shortfalls and the associated impacts that have effectively ended funding for efficiency and renewable energy programs, the Renewable Energy Alaska Project is educating business and policymakers on the benefits of establishing a state green bank. ${ }^{73}$ The organization is consulting with the successful Connecticut Green Bank, and that entity's chief investment officer visited Alaska twice in the first half of 2017 to assist in the education process, which included testimony in front of the Alaska legislature. A green bank would leverage the state's public dollars by buying down the risk of clean energy projects and attracting investments from the private banking community.

As noted above, through the Renewable Energy Alaska Project the IGRC has also addressed lack of clear regulatory policy defining the rules of engagement among the Railbelt region's six

\footnotetext{
72 A small, isolated transmission system in Alaska that covers the main population centers of the state along the main railroad line including the Seward, the Kenai, Anchorage, Wasilla, and north to Fairbanks

${ }^{73}$ http://alaskarenewableenergy.org/wp-content/uploads/2017/08/A-Green-Bank-for-Alaska.pdf
} 
utilities and independent power producers that wish to develop wind. This work has taken many forms, including direct engagement with the utilities, the Regulatory Commission of Alaska, the state legislature, and other interested stakeholders. The Regulatory Commission of Alaska has recommended reforms, including the formation of system operator and a transmission company for the region that would be responsible for upgrades on the relatively weak, inflexible grid. While the formation of the transmission company has been largely driven by an out-of-state entity, the Renewable Energy Alaska Project and the IGRC are driving the discussion revolving around the formation of a system operator and the need for a new set of predictable market rules that will give independent power producers more certainty about their potential investments.

In 2017, three of Alaska's six Railbelt utilities (Chugach Electric, Municipal Light \& Power, and Matanuska Electric Association) signed a power pooling agreement that will allow the groups to collectively utilize transmission and generation resources. The collaboration is expected to save the utilities \$12 million to \$16 million a year in fuel and operations and maintenance costs, and it is also expected to reduce $\mathrm{CO}_{2}$ emissions by 90,000 to 120,000 tons per year (Chugach Electric 2017).

Alaskans are also connected to many efforts to continue optimizing wind-diesel hybrid systems, including the Arctic Remote Energy Networks Academy ${ }^{74}$ to create pan-Arctic training for small grids and a microgrid modernization effort led by four national laboratories. The first cohort of the program attended the 2017 Alaska Wind-Diesel Workshop ${ }^{75}$ in Fairbanks, Alaska. During the event sponsored by the Alaska Energy Authority and supported by the IGRC, the Arctic Remote Energy Networks Academy attendees received in-depth training on the HOMER Energy modeling software and heard from a variety of speakers, including utility operators, researchers, and others, about the pitfalls and opportunities of implementing renewables onto remote grids.

\subsubsection{American Samoa}

American Samoa, an unincorporated territory of the United States, is a group of five islands about halfway between Hawaii and New Zealand in the South Pacific Ocean. The territory's only utility, the American Samoa Power Authority, provides electric, water, wastewater, and solid waste utility services for its 12,300 customers. American Samoa is almost completely dependent on fossil fuels for meeting its energy generation needs. In 2015, the peak load averaged about 23 MW with annual diesel generation totaling 154 million kilowatt-hours. As of late 2015, American Samoa Power Authority obtained about 2.4\% of its electricity from solar photovoltaic facilities.

A study ${ }^{76}$ conducted by AWS Truepower in 2014 and sponsored by American Samoa Power Authority identified some potential wind power sites around Tutuila, the primary island. Two 100-kilowatt Power Works turbines have been purchased to install as a pilot project. As of July 2017, the American Samoa Power Authority and American Samoa Renewable Energy Committee were seeking funds to install the turbines. ${ }^{77}$

\footnotetext{
74 http://acep.uaf.edu/programs/arena.aspx

75 http://islandedgrid.org/13522-2/

${ }^{76}$ Available at http://www.asrec.net/wp-content/uploads/2016/03/Wind-Resource-Study_2014_DRAFT_2014-1027-4378826.pdf

${ }^{77}$ Personal communication with Mark Kneubuhl, American Samoa Renewable Energy Committee
} 
In 2013, the governor established the American Samoa Renewable Energy Committee, which developed a strategic energy plan and energy action plan. Notably, the plan included a goal for the Manu'a Islands, American Samoa's easternmost group, to be $100 \%$ powered by renewables by 2016. This group consists of three islands: Ta' $u$, Ofu, and Olosega. As of May 2017, the island group was generating about $90 \%$ of its electricity from the sun using a $1.41-\mathrm{MW}$ photovoltaic solar system combined with a 6 megawatt-hour lithium ion battery system that was installed and commissioned in 2016 on Ta'u. In addition, in 2017, a U.S. Department of Interior Office of Insular Affairs-funded system was installed on Ofu that consists of a 347-kW solar system and 1,000-kWh AHI ("Salt Water”) of battery storage. Planners considered installing wind power to reach the $100 \%$ goal but opted instead for a second phase of solar and storage, scheduled for completion in 2018 (American Samoa Renewable Energy Committee 2017).

\subsubsection{Hawaii}

There are currently no offshore wind farms in Hawaii, but there are multiple proposals for offshore wind development. A.W. Hawaii Wind, a Texas company that is a subsidiary of Denmark-based Alpha Wind Energy, is proposing two offshore floating wind farms, each generating about $400 \mathrm{MW}$ of energy with 50 turbines. One is proposed for the northwest side of Oahu, 12 miles off the coast of Kaena Point. The other proposed wind farm would be sited in waters 17 miles south of Diamond Head, also off Oahu. A second company, Progression Hawaii Offshore Wind, is also proposing a 400-MW wind farm using 40 to 50 floating turbines off Oahu's South Shore. Statoil Wind has also expressed interest in siting a wind farm off Oahu.

To analyze the employment and economic potential for floating offshore wind off Hawaii's coasts, the Bureau of Ocean Energy Management commissioned NREL to analyze two hypothetical deployment scenarios for Hawaii: $400 \mathrm{MW}$ of offshore wind by 2050 and $800 \mathrm{MW}$ of offshore wind by 2050. Results show total state gross domestic product impacts of \$348 million in the 800-MW scenario and \$203 million in the 400-MW scenario for the construction phases; and \$993 million in the 800-MW deployment and \$539 million in the 400-MW project for the operations phases (Jimenez et al. 2016).

With $206 \mathrm{MW}$ of land-based wind installed, the state continues to garner interest in developing its onshore wind resource. In December 2016, Hawaii Electric Light Company released its latest Power Supply Improvement Plan that will help guide the utility's transition to meeting the state RPS of $100 \%$ by 2040 (5 years earlier than required). The plan calls for an additional $157 \mathrm{MW}$ of wind energy to be constructed through 2021. In December 2016, the company also released a request for information regarding properties that are available for renewable energy development (including wind) (Hansel 2016).

Hurdles to wind development in Hawaii include endangered avian and plant species that can complicate the siting and development of wind projects in Hawaii's unique environments and U.S. military operations. Visual impacts can also be of concern, given the limited sites suitable for wind development in Hawaii. The Hawaii Clean Energy Programmatic Environmental Impact Study released in September 2015 catalogued at a high level the various environmental impacts of onshore and offshore utility-scale wind, as well as other renewable energy technologies that would likely be considered in a project-specific environmental review (U.S. Department of Energy 2015d). 


\subsubsection{Guam}

Guam, the largest island in Micronesia, is located in the Pacific Ocean about three-fourths of the way from Hawaii to the Philippines. Surrounded by coral reef, Guam sits on the edge of the Mariana Trench and its Challenger Deep, the deepest known place on earth. The island's population is estimated to be about 162,000 , plus 12,000 to 14,000 military personnel and their dependents. Guam meets nearly all of its energy needs, including electricity, with petroleum products shipped in by tanker.

Guam has substantial wind potential but also unique siting issues. It is seismically active and is in the Pacific's Typhoon Alley, so wind turbines must be engineered to resist earthquakes and typhoon-force winds. Other barriers to wind development on Guam include limited land, concerns over aesthetics of wind turbines, a large amount of military land that may create issues with zoning variances, no local tax incentive, sensitive bat species, and other potential environmental impacts. Both the Navy and Guam Power Authority have conducted wind resource mapping and assessments. The Guam Power Authority installed a pilot project, a 275kW Vergnet turbine on a tilt-up tower (Dumat-ol Daleno 2016). The turbine began supplying power to residents in early 2016 and is being used to test the viability of utility-scale wind on the island's grid. The Guam Power Authority also has deployed several grid-connected PV projects and in 2017 signed a contract with LG CNS to add 40 MW of energy storage using lithium ion batteries (Guam Consolidated Commission on Utilities 2017).

New legislation was proposed that would create a renewable energy task force to advise the island's utility as it looks to expand power generation by 180 MW. Announced in April 2017, Bill 78-34 designates a team of public and private stakeholders that would help ensure renewable energy options are maximized during this expansion (Mora 2017).

The Center for Island Sustainability at the University of Guam ${ }^{78}$ hosts an annual clean energy conference that brings participants from across the South Pacific to discuss the challenges and opportunities of deploying renewable energy on islanded grids along with other sustainability topics.

Guam currently has a renewable energy portfolio goal that calls for $25 \%$ of net electricity sales to come from renewable energy resources by 2035.

\subsubsection{Commonwealth of the Northern Mariana Islands}

The CNMI is a chain of 14 islands in the Pacific Ocean, located between Hawaii and the Philippines. The CNMI has three small electric grids, one on each of the three inhabited islands on the southern end of the island chain. Generating capacity is about 70 MW on Saipan, $20 \mathrm{MW}$ on Tinian, and 4.5 MW on Rota. Approximately 90\% of residents live on Saipan, the largest island. The total population, about 54,000 in the 2010 U.S. Census, has been shrinking. The islands meet nearly all of their energy demand through imported petroleum products, including 22 million to 24 million gallons of diesel fuel to run the islands' five electricity-generating plants every year. The CNMI's electric system is owned and operated by Commonwealth Utilities Corporation, a public corporation of the CNMI government.

${ }^{78}$ http://www.uog.edu/center-for-island-sustainability/center-for-island-sustainability-cis 
Saipan, Tinian, and Rota are believed to have prevailing wind resources suitable for commercial turbines. However, potential sites are limited because the islands are mountainous, land is scarce, and turbines may interfere with airstrip and military facilities. Initial site assessments have identified locations that could be assessed further, and researchers performed a technical assessment that details current energy consumption and production data to establish a baseline for the CNMI. ${ }^{79}$ There are also concerns about turbine impacts on several unique threatened bird species. Turbines must also be designed to withstand typhoons. In August 2015, Typhoon Soudelor struck Saipan and caused extensive damage, including to the island's power generation and transmission infrastructure.

The CNMI's renewable portfolio standard requires $20 \%$ of net electricity sales to come from renewable energy resources by 2016 if cost-effective resources are available. Only small-scale wind and solar resources have been built, mostly at government and school facilities, and no assessments have been conducted to understand the costs of deploying large-scale solar or wind systems. The RPS also requires government departments to help the Commonwealth Utilities Corporation and developers locate potential renewable energy sites, assist in planning and permitting, and publish a list of sites for potential renewable energy development every 2 years (National Renewable Energy Laboratory 2015a).

\subsubsection{Northeast Island Communities}

Several New England island communities have investigated community-scale wind as a costeffective option for reducing high, primarily diesel-based energy costs, but no wind power generation has been installed on the islands since the 4.5-MW Fox Islands Wind Project was constructed in 2009, for many of the reasons cited above.

In August 2016, construction was completed on the 30-MW Deepwater Wind project off Block Island, Rhode Island, and the project came online in December 2016. It connects Block Island, an islanded grid, to the mainland grid, changing its grid status. The IGRC worked with Block Island community leaders and other island communities that face the potential development of large-scale offshore wind projects, sharing the lessons learned by the Monhegan Energy Task Force as it interacted with the Maine Aqua Ventus project, a 12-MW, two-turbine offshore wind project proposed off the coast of Monhegan Island, Maine.

In May 2016, DOE announced that the Maine Aqua Ventus I offshore wind project (also called New England Aqua Ventus) would be considered a recipient of up to $\$ 40$ million of funding, subject to progress reviews, to develop the project. The Monhegan Energy Task Force is working to inform the island community about the project and to represent it in communications with Maine Aqua Ventus. The task force is leading the community in a process to define local benefits from the project and to assess local priorities and concerns.

The Island Institute is also working to build on its existing partnership with DOE and NREL through the Energy Planning for Island Communities initiative. Within DOE, the Island Institute is partnering with the Energy Transition Initiative (ETI), ${ }^{80}$ a subset of the agency's Technology to Market program that works with government entities and other stakeholders to establish a

\footnotetext{
79 http://www.nrel.gov/docs/fy110sti/50906.pdf

80 http://energy.gov/eere/technology-to-market/energy-transition-initiative
} 
long-term energy vision and implement energy efficiency and renewable energy solutions. ETI provides a proven framework and technical resources and tools to help islands, states, and cities transition to a clean energy economy and achieve their clean energy goals. ETI programs available to the Island Institute and its partners include the Island Energy Playbook, ${ }^{81}$ a guide that any community can use to help successfully initiate, plan, and complete a transition to a clean energy system, as well as related tools, trainings, and technical assistance.

DOE's ETI program also facilitated a partnership between the Island Institute and NREL's Technology Deployment program, specifically its team of experts that manage NREL's REopt ${ }^{82}$ energy planning platform. REopt is being used to analyze cost-optimal paths to help Maine island communities reduce their fuel consumption and lower their energy costs through the utilization of high-contribution renewable energy systems and related measures. This type of indepth analysis will provide insights on how to operate existing and incorporate new energy assets to reduce costs, meet energy or carbon goals, and improve resiliency. This work was featured on DOE's Office of Energy Efficiency and Renewable Energy blog in November 2016. ${ }^{83}$

\subsubsection{Puerto Rico}

With nearly 125 MW of utility scale wind installed on the island, Puerto Rico's first wind development, the 101.2-MW Santa Isabel Wind Farm, began operating in 2012. Hurricane Maria left the island's electrical infrastructure in various forms of disarray, including damage to the 23.4-MW Punta de Lima Wind Farm.

In October 2017, The Distributed Wind Energy Association reported that its members would be sending turnkey microgrids to help Puerto Rico and other Caribbean islands that lost power as a result of Hurricane Maria. Puerto Rico's utility reports that some of its customers may be without electricity into 2018. Companies such as Tesla are delivering microgrids, solar panels, and energy storage batteries to provide more immediate relief. Wind industry companies contributing to the effort include Northern Power Systems, Primus Wind Power, XZERES, Oregon, and United Wind.

\subsubsection{U.S. Virgin Islands}

The U.S. Virgin Islands is a U.S. territory made up of three primary islands in the Caribbean, about 600 miles from Miami, Florida. The territory has two separate electricity grids, each with its own generation, managed by the Water and Power Authority, an independent government agency. Generating units include combustion, steam turbines, and backup diesel, all fueled by imported petroleum. The 199-MW St. Thomas system supplies nearby St. John and Water Island by underwater cable. The 122-MW St. Croix system, separated from St. Thomas by 40 miles of ocean, has its own grid. The U.S. Virgin Islands government's goal of reducing fossil fuel use $60 \%$ by 2025 has led to working with U.S. federal agencies and industry to find other energy sources. More than half of reductions are planned to come from energy efficiency, particularly in

\footnotetext{
${ }^{81} \mathrm{http}: / /$ www.eere.energy.gov/islandsplaybook/

82 http://www.nrel.gov/tech deployment/tools reopt.html

${ }^{83} \mathrm{http}: / /$ energy.gov/eere/articles/consider-lobster-and-electricity-helping-meet-energy-challenges-maines-smallislands
} 
generation, transmission, street lighting, and desalination, with the balance coming from wind, solar, and biomass technologies, including waste-to-energy and landfill gas.

In August 2017, the Water and Power Authority Governing Board unanimously voted to authorize its executive director to begin negotiations with Advance Power, LLC for a 10-MW wind farm on St. Thomas. If approved, the project will have the potential to produce about onesixth of the island's total peak power consumption (O’Connor 2017).

According to DOE's ETI, the U.S. Virgin Islands have up to 34 MW of wind potential (National Renewable Energy Laboratory 2015b). There is potential for commercial wind energy resources, but finding the large sites needed for utility-scale projects on the islands has been challenging. The most promising locations for utility-scale wind projects are on high ridges and exposed capes. The Virgin Islands Water and Power Authority, in conjunction with the Virgin Islands Energy Office, completed wind studies to determine the economic feasibility of wind power development in the territory. Data collected in 2012 and 2013 at potential sites around Longford on St. Croix and the Bovoni Peninsula on St. Thomas found wind speeds suitable for large turbines that could help the U.S. Virgin Islands meet its 60\% by 2025 goal. As of September 2016, the Water and Power Authority is preparing to negotiate with several Qualified Facilities proposing wind projects that were approved by the Public Services Commission pursuant to the Cogeneration and Small Power Production Act. The utility is currently creating a request for proposal for these Qualified Facilities. The size of the proposed wind farm is 7 to $10.5 \mathrm{MW}$ (Joseph 2016). 


\section{Midwest Region}

Colleagues from the Midwest Wind Energy Center (MWEC) and the National Renewable Energy Laboratory (NREL) collaborated to provide the following assessment of the state of the wind industry in this region.

The MWEC ${ }^{84}$ serves Illinois, Indiana, Iowa, Michigan, Minnesota, Missouri, eastern Montana, ${ }^{85}$ North Dakota, Ohio, South Dakota, and Wisconsin (see Figure 4). The MWEC's main organizer is Windustry, along with key partners Tom Wind of Wind Utility Consulting and renewable energy consultant Dan Turner. This section provides an overview of the wind industry in the Midwest region.

\subsection{Overview of Regional Wind Market}

The MWEC states are quite diverse from a wind development perspective. The states in the western portion of the region (Montana, the Dakotas, Iowa, and western Minnesota) have strong, world-class winds and vast rural areas. The states in the eastern portion of the region (Ohio, Indiana, and Michigan) have moderate and low wind resources. Additionally, some states (Illinois, Ohio) have dense populations in some of their windiest areas and are limited in the extent of their land-based development (assuming 80-m hub heights).

Table 10. Key Statistics for States in the Midwest Wind Energy Center Region

\begin{tabular}{|c|c|c|c|c|c|c|c|c|c|c|}
\hline & IL & IN & IA & MI & MN & MO & ND & $\mathrm{OH}$ & SD & WI \\
\hline $\begin{array}{l}\text { Installed Wind } \\
\text { (MW), End of } \\
4 \mathrm{Q} 17^{86}\end{array}$ & 4,332 & 2,117 & 7,308 & 1,860 & 3,699 & 959 & 2,996 & 617 & 977 & 746 \\
\hline $\begin{array}{l}\text { Percentage of } \\
\text { In-State } \\
\text { Energy } \\
\text { Production (as } \\
\text { of End of } \\
2016)^{87}\end{array}$ & $5.7 \%$ & $4.8 \%$ & $36.6 \%$ & $4.2 \%$ & $17.7 \%$ & $1.4 \%$ & $21.5 \%$ & $1.1 \%$ & $30.3 \%$ & $2.3 \%$ \\
\hline $\begin{array}{l}2017 \text { Wind } \\
\text { Power } \\
\text { Capacity } \\
\text { Additions } \\
(\mathrm{MW})^{\mathbf{8 8}}\end{array}$ & 306 & 220 & 164 & 250 & 200 & 300 & 603 & 72 & 0 & 98 \\
\hline $\begin{array}{l}\text { Wind Capacity } \\
\text { under } \\
\text { Construction } \\
(\mathrm{MW}) \text {, End of } \\
4 \mathrm{Q} 17^{89}\end{array}$ & 344 & 330 & 736 & 44 & 201 & 0 & 0 & 275 & 208 & 0 \\
\hline
\end{tabular}

\footnotetext{
${ }^{84}$ http://www.midwestwindenergycenter.org/

${ }^{85}$ In this report, a Montana summary is provided in Section 6, which covers the Northwest region

${ }^{86}$ American Wind Energy Association 2018

${ }^{87}$ American Wind Energy Association 2017a

${ }^{88}$ American Wind Energy Association 2018

${ }^{89}$ American Wind Energy Association 2018
} 


\begin{tabular}{|c|c|c|c|c|c|c|c|c|c|c|}
\hline & IL & IN & IA & MI & MN & MO & ND & $\mathrm{OH}$ & SD & WI \\
\hline $\begin{array}{l}\text { Projected } \\
\text { Potential } \\
\text { Capacity } \\
\text { (MW), } 80 \text { m, } \\
\text { 30\% Capacity } \\
\text { Factor }\end{array}$ & 249,882 & 148,228 & 570,714 & 59,042 & 489,271 & 274,355 & 770,196 & 54,920 & 882,412 & 103,757 \\
\hline $\begin{array}{l}\text { Projected } \\
\text { Potential } \\
\text { Capacity } \\
\text { (MW), } 100 \text { m, } \\
\text { 30\% Capacity } \\
\text { Factor }\end{array}$ & 329,618 & 183,832 & 601,957 & 179,056 & 603,427 & 399,635 & 771,791 & 123,328 & 890,626 & 215,447 \\
\hline $\begin{array}{l}\text { Distributed } \\
\text { Wind } \\
\text { Capacity, as } \\
\text { of December } \\
2016(\mathrm{MW})^{90}\end{array}$ & 26.5 & 9.2 & 129.2 & 0.3 & 133.6 & 5.1 & 7.8 & 42.1 & 1.7 & 19.6 \\
\hline $\begin{array}{l}\text { Proposed } \\
\text { Offshore Wind } \\
\text { Projects } \\
(\mathrm{MW}) \text {, End of } \\
2016^{91}\end{array}$ & 0 & 0 & 0 & 0 & 0 & 0 & 0 & $20.7^{92}$ & 0 & 0 \\
\hline
\end{tabular}

Sources: American Wind Energy Association, U.S. DOE

The states in the MWEC region have vastly different energy demands, with many energy plants in transition. This region has historically relied heavily on central station coal and nuclear plants for most of its electricity generation, but wind and solar projects are also abundant here.

The energy demand of Illinois, the most populous state, is spurring development of transmission to allow expanded renewable energy development. Two large transmission projects dedicated to addressing wind generation in the MWEC region are currently in the planning process. One project is the Rock Island Clean Line, a 500-mile overhead direct current transmission line that will deliver 3,500 megawatts (MW) from northwest Iowa and the surrounding region to communities in Illinois and other states to the east. First proposed in 2010, Rock Island Clean Line developers worked for 6 years to secure needed regulatory approvals in Illinois. In 2014, the state's utility regulator, the Illinois Commerce Commission, unanimously approved the project. Opposition from Commonwealth Edison and landowner groups resulted in the Third District Appellate Court reversing the approval. In September 2016, stakeholders asked the Illinois Supreme Court to take up the case (Clean Line Energy Partners 2016a). A September 2017 decision against the project ${ }^{93}$ concluded that since the project developer is not considered a public utility, the Rock Island Clean Line was inappropriately approved by state regulators

\footnotetext{
${ }^{90}$ Distributed wind project capacity is defined as cumulative capacity, 2003-2016 (DOE 2017a).

${ }^{91}$ American Wind Energy Association 2017b

92 The Icebreaker Project on Lake Erie

${ }^{93}$ http://www.illinoiscourts.gov/Opinions/SupremeCourt/2017/121302.pdf
} 
(Daniels 2017). Another planned project is the Grain Belt Express Clean Line, a 750-mile directcurrent transmission line that will connect the wind resources of Kansas to Missouri, Illinois, Indiana, and markets farther east. Developers are working to secure the final required regulatory approvals, and construction could begin as early as 2018 (Clean Line Energy Partners 2016b).

On the generation side, seven Sioux tribes in the Dakotas have launched an innovative wind development project by forming a partnership to develop wind farms on six reservations across South Dakota and North Dakota as part of a corporation, Oceti Sakowin Power Authority. In July 2017, the Oglala Sioux Tribe voted in favor of committing $\$ 4$ million to be used as collateral for a \$10 million loan to the Oceti Sakowin Power Authority to support the project (Crash 2017). The Power Authority received $\$ 400,000$ in grants from private foundations and has performed some preliminary planning work with the support of the U.S. Department of Energy's (DOE's) Office of Indian Energy. The project is expected to support 400 construction jobs and 40 full time jobs when it is completed (Crash 2017). The Oceti Sakowin Power Authority is also planning significant investments in transmission to move the wind power from the rural areas of South Dakota and North Dakota to more populous markets. Stakeholders can consult the DOE's interactive Wind Vision Study Scenario Viewer ${ }^{94}$ to learn more about statespecific costs, benefits, and other impacts from wind energy development related to the Wind Vision scenarios.

\subsubsection{Renewable Portfolio Standards}

In the MWEC region, eight states have a renewable portfolio standard (RPS) (Illinois, Iowa, Michigan, Minnesota, Missouri, Montana, Ohio, and Wisconsin), and three states have a renewable energy goal (Indiana, North Dakota, and South Dakota).

Table 11. RPS Overview for States Served by the Midwest Wind Energy Center

\begin{tabular}{ll}
\hline & RPS \\
\hline Illinois & $25 \% \times 2026$ \\
\hline Indiana & Clean Energy Portfolio Goal of $10 \% \times 2025$ \\
& $\begin{array}{l}\text { Investor-owned utilities must contract for a total of } 105 \text { MW of } \\
\text { renewables }\end{array}$ \\
\hline Iowa & $15 \% \times 2021$ \\
\hline Michigan & $26.5 \% \times 2025$ (investor-owned utilities) \\
\hline Minnesota & $31.5 \% \times 2020$ (Xcel) \\
\hline Missouri & $15 \% \times 2021$ \\
\hline North Dakota & Goal of $10 \% \times 2015$ \\
\hline Ohio & $12.5 \% \times 2026$ \\
\hline South Dakota & Goal of $10 \% \times 2015$ \\
\hline Wisconsin & $10 \% \times 2015$ \\
\hline
\end{tabular}

Source: Database of State Incentives for Renewables \& Efficiency

94 http://en.openei.org/apps/wv_viewer/ 
According to a recent Lawrence Berkeley National Laboratory publication (Kuckro 2016), RPSs are proving successful as $60 \%$ of renewable energy generation since 2000 is the product of RPSs. Michigan, Montana, and Wisconsin have reached their RPS targets for 2015. (Iowa surpassed its target.) The other states in the region are still aiming for their target goals.

\subsubsection{Communities with $100 \%$ Renewable Energy Commitments}

Many state public utility commissions are working with utilities to choose the direction of their energy portfolios. While some states have mandated and voluntary renewable energy goals or standards, some cities have taken an additional step to create their own commitments to clean energy, some of which exceed levels established by their states. Two communities in the Midwest Region have made 100\% renewable energy commitments (Table 12).

Table 12. Communities Served by the Midwest Regional Resource Center with $100 \%$ Renewable Energy Commitments

\begin{tabular}{llll}
\hline City & State & Target Year \\
\hline Madison & WI & TBD \\
Rock Port & MO & Achieved in 2008 \\
\hline
\end{tabular}

Source: Sierra Club

\subsection{Workforce Development}

Educating the future generations of wind energy technicians, engineers, and stakeholders plays a key role in developing the domestic wind workforce. Figure 10 shows the school installations and educational programs for wind energy in the MWEC area. Iowa Lakes Community College was one of the first in the country to offer a wind technician training program and has been providing wind energy education since 2003. Another established program in the region is Minnesota West Community and Technical College. Minnesota West offers the following programs: wind energy mechanic (diploma), wind energy technology (Associate of Applied Science degree), and windsmith (certificate). The University of Iowa and Iowa State University have been active members of the North American Wind Energy Academy.

Educational activities are described in more detail in the state sections below. The WINDExchange website also offers information and interactive maps regarding workforce development, DOE's Collegiate Wind Competition, DOE's Wind for Schools project, school wind project locations, and locations of education and training programs in the MWEC region and other states. ${ }^{95}$

${ }^{95}$ https://windexchange.energy.gov/education-workforce 


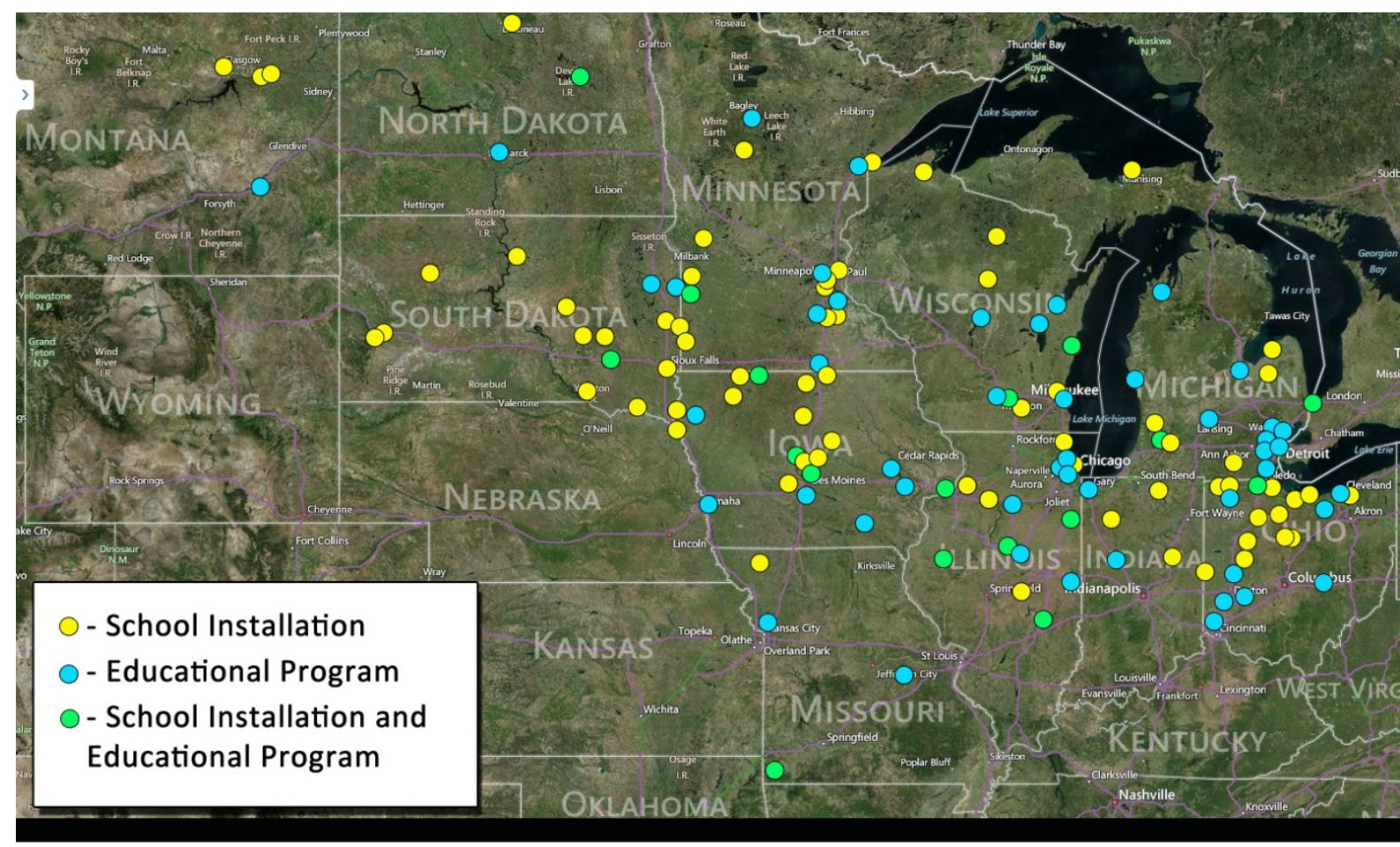

\section{Midwest Wind Energy Center}

(Eastern MT, ND, SD, MN, IA, MO, WI, IL, IN, MI, OH)

Figure 10. Map of school wind turbine projects, educational programs, and locations with both wind turbines and educational programs within the Midwest Wind Energy Center's area

\subsection{Manufacturing and Economic Development}

Mirroring the large investments in wind deployment, the Midwest region has extensive wind manufacturing infrastructure. NREL researchers compiled the following wind energy manufacturing data for this region as part of DOE's annual wind market report effort (U.S. Department of Energy 2017c).

Table 13. Wind-Related Manufacturing Overview for States Served by the Midwest Wind Energy Center

\begin{tabular}{llll}
\hline Name & City & State & Component \\
\hline Brad Foote Gear Works & Cicero & IL & Power transmission gears \\
Centa Corp. & Aurora & IL & Couplings \\
Chicago Industrial Fasteners & West Chicago & IL & Blade studs \\
\hline Deublin Company & Waukegan & IL & Slip rings, hydraulic components \\
Finkl and Sons & Chicago & IL & Components \\
\hline HYDAC & Glendale Heights & IL & Hydraulics, brake systems \\
Randack Fasteners America & Lake Zurich & IL & Bolts \\
\hline R\&W America & Bensenville & IL & Couplings
\end{tabular}




\begin{tabular}{|c|c|c|c|}
\hline Name & City & State & Component \\
\hline Siemens/Winergy & Elgin & IL & Gear drive \\
\hline SMF & Minonk & IL & Embed rings, template rings \\
\hline $\begin{array}{l}\text { Stanley Machining \& Tool } \\
\text { Corp. }\end{array}$ & Carpentersville & IL & $\begin{array}{l}\text { Gear cases, torque arms, } \\
\text { planetary carriers }\end{array}$ \\
\hline $\begin{array}{l}\text { Stanley Machining \& Tool } \\
\text { Corp. }\end{array}$ & Hampshire & IL & $\begin{array}{l}\text { Gear cases, torque arms, } \\
\text { planetary carriers }\end{array}$ \\
\hline Trinity Structural Towers & Clinton & IL & Towers \\
\hline Winergy Drive Systems & Elgin & IL & Gear drive \\
\hline Bedford Machine and Tool & Bedford & IN & Rotor hubs and plates \\
\hline $\begin{array}{l}\text { Carlisle Industrial Brakes and } \\
\text { Friction }\end{array}$ & Bloomington & IN & Brakes \\
\hline Oerlikon Fairfield & Lafayette & IN & Gears \\
\hline D.A.D. Manufacturing & Lisbon & IA & Walkways, doors, components \\
\hline D.A.D. Manufacturing & Hiawatha & IA & Walkways, doors, components \\
\hline MM Composite & Fort Madison & IA & Composite components \\
\hline Siemens & Fort Madison & IA & Blades \\
\hline TPI Composites & Newton & IA & Blades \\
\hline Trinity Structural Towers & Newton & IA & Towers \\
\hline Akebono Corp. & Farmington Hills & MI & Brakes \\
\hline Creative Foam & Fenton & MI & Blade cores \\
\hline Genzink Steel & Holland & MI & Generator frames \\
\hline $\begin{array}{l}\text { Great Lakes Gear } \\
\text { Technology }\end{array}$ & Canton & MI & Gears \\
\hline K\&M Machine Fabricating & Cassopolis & MI & Hub and gearbox housings \\
\hline Three M Tool and Machine & Wixom & MI & $\begin{array}{l}\text { Gearbox housings and forward } \\
\text { housings }\end{array}$ \\
\hline Three M Tool and Machine & Commerce & MI & $\begin{array}{l}\text { Gearbox housings and forward } \\
\text { housings }\end{array}$ \\
\hline Ventower & Monroe & MI & Towers \\
\hline Columbia Gear Corporation & Avon & MN & Gears \\
\hline KEB America & Shakopee & MN & Pitch and yaw drives \\
\hline Millwood Metal Works & Freeport & MN & $\begin{array}{l}\text { Embed rings, template rings, } \\
\text { forms }\end{array}$ \\
\hline Rotary Systems & Ramsey & MN & Slip rings \\
\hline Ventera Wind & Duluth & MN & Distributed wind \\
\hline Wind Turbine Industries Corp. & Prior Lake & MN & Distributed wind \\
\hline Zero-Max & Plymouth & MN & Couplings \\
\hline AZZ Inc & Fulton & $\mathrm{MO}$ & Switch gears \\
\hline
\end{tabular}




\begin{tabular}{|c|c|c|c|}
\hline Name & City & State & Component \\
\hline CG Power Systems & Washington & MO & Electrical \\
\hline Continental Disc Corporation & Liberty & MO & Brakes \\
\hline FAG Bearings & Joplin & MO & Bearings \\
\hline Gasket Engineering & Kansas City & MO & Blade components \\
\hline Vest-Fiber & Moberly & MO & Components \\
\hline LM Wind Power & Grand Forks & ND & Blades \\
\hline Trinity Structural Towers & West Fargo & ND & Towers \\
\hline Advanced Manufacturing & Cleveland & $\mathrm{OH}$ & Gearboxes \\
\hline Aerotorque Corporation & Sharon Center & $\mathrm{OH}$ & Torsion control \\
\hline Allied Moulded Products & Bryan & $\mathrm{OH}$ & Control housings \\
\hline $\begin{array}{l}\text { The American Tank and } \\
\text { Fabricating Company }\end{array}$ & Cleveland & $\mathrm{OH}$ & Power transmission components \\
\hline The Benjamin Company & Put-In-Bay & $\mathrm{OH}$ & Power transmission components \\
\hline Canton Drop Forge & Canton & $\mathrm{OH}$ & Gear blanks \\
\hline CMC/BMC Utility Products & Hamilton & $\mathrm{OH}$ & Power transmission components \\
\hline Cast Fab & Cincinnati & $\mathrm{OH}$ & Ductile iron component castings \\
\hline CMC/BMC Utility Products & Hamilton & $\mathrm{OH}$ & Power transmission components \\
\hline Dyson Corp. & Painseville & $\mathrm{OH}$ & Fasteners \\
\hline Eaton Corp. & Cleveland & $\mathrm{OH}$ & Electrical \\
\hline Edco Inc. & Toledo & $\mathrm{OH}$ & Power transmission machining \\
\hline EGC Enterprises & Chardon & $\mathrm{OH}$ & Fasteners \\
\hline Elyria Foundry & Elyria & $\mathrm{OH}$ & Component castings \\
\hline Federal Gear & Willoughby & $\mathrm{OH}$ & Gears \\
\hline Horsburgh and Scott & Cleveland & $\mathrm{OH}$ & Gears \\
\hline Industrial Nut Corporation & Sandusky & $\mathrm{OH}$ & Fasteners \\
\hline Kalt Manufacturing & North Ridgeville & $\mathrm{OH}$ & Large components \\
\hline Kaydon Bearing & Avon & $\mathrm{OH}$ & Bearings \\
\hline Magna Machine & Forest Park & $\mathrm{OH}$ & Rotor hubs, support bases \\
\hline Midwest Industrial Castings & Minster & $\mathrm{OH}$ & Castings \\
\hline Milacron Inc & Mount Orab & $\mathrm{OH}$ & Components \\
\hline Parker Hannifin Corp. & Mayfield Heights & $\mathrm{OH}$ & Hydraulic components, brakes \\
\hline Rotek Inc. & Aurora & $\mathrm{OH}$ & Slew bearings \\
\hline Swiger Coil Systems & Cleveland & $\mathrm{OH}$ & Generators \\
\hline Marmen & Brandon & SD & Towers \\
\hline Molded Fiber Glass & Aberdeen & SD & Blades \\
\hline ABB & New Berlin & WI & Motors, drives \\
\hline
\end{tabular}




\begin{tabular}{|c|c|c|c|}
\hline Name & City & State & Component \\
\hline Applied Plastics & Oak Creek & WI & Extrusions \\
\hline Bassett Mechanical & Kaukauna & WI & $\begin{array}{l}\text { Embed rings, template rings, } \\
\text { forms }\end{array}$ \\
\hline Broadwind & Manitowoc & WI & Towers \\
\hline Cooper Power Systems & Waukesha & WI & Electrical \\
\hline Fives Giddings and Lewis & Fond du Lac & WI & $\begin{array}{l}\text { Turbine housing, gearbox, } \\
\text { bearings }\end{array}$ \\
\hline Helwig Carbon Products & Milwaukee & WI & Carbon brushes \\
\hline Ingeteam & Milwaukee & WI & Generators \\
\hline Lindquist Machine & Green Bay & WI & $\begin{array}{l}\text { Gearbox, pitch linkage, main } \\
\text { shafts, gearbox rebuilds }\end{array}$ \\
\hline Magnetek & Menomonee Falls & WI & Power converters \\
\hline Matenaer Corporation & West Bend & WI & Machined components \\
\hline Milwaukee Gear Company & Milwaukee & WI & Gears \\
\hline Milwaukee Machine Works & Milwaukee & WI & Gearbox housings \\
\hline Plexus & Neenah & WI & Electronic components \\
\hline Rexnord Gear & Antigo & WI & Gears \\
\hline
\end{tabular}

Additional economic impacts from wind development include the capital investment, jobs supported, tax revenues paid, payments in lieu of taxes, and land lease payments made by wind developers during construction and the ongoing maintenance of wind plants. The American Wind Energy Association performs modeling work that identifies the impacts of all wind-related investment. Table 14 summarizes the total jobs (including construction jobs in 2016) and capital investment over time in wind farms in the MWEC states. Examples of economic impacts are provided in each of the state overviews below. 
Table 14. Economic Impacts of Wind Development in States Served by the Midwest Wind Energy Center

\begin{tabular}{lll}
\hline State & Direct and Indirect Jobs Supported & Total Capital Investment \\
\hline Illinois & 4,001 to 5,000 & $\$ 8.4$ billion \\
\hline Indiana & 1,001 to 2,000 & $\$ 4.1$ billion \\
\hline Iowa & 8,001 to 9,000 & $\$ 13.5$ billion \\
\hline Michigan & 2,001 to 3,000 & $\$ 3.1$ billion \\
\hline Minnesota & 3,001 to 4,000 & $\$ 6.8$ billion \\
\hline Missouri & 1,001 to 2,000 & $\$ 1.4$ billion \\
\hline North Dakota & 4,001 to 5,000 & $\$ 5.4$ billion \\
\hline Ohio & 2,001 to 3,000 & $\$ 1.1$ billion \\
\hline South Dakota & 1,001 to 2,000 & $\$ 2.1$ billion \\
\hline Wisconsin & 1,001 to 2,000 & $\$ 1.4$ billion \\
\hline
\end{tabular}

Source: American Wind Energy Association 2017a; as of 2016

\subsection{Key Stakeholder Groups and Development Challenges}

The MWEC focuses outreach efforts on the following stakeholder groups:

- Engaged citizens, including those impacted by existing or planned wind power projects, members of local energy committees, and community organizations supportive of or concerned about wind energy impacts

- Educators, students, media, and members of the general public interested in learning more about wind energy

- Policymakers, including regulators, legislators, and administrators

- Policy implementers, including state, regional, and local regulatory/planning authorities, health department, municipal officials (e.g., planning board, economic development, etc.), siting and permitting officials and staff

- Utility representatives: municipal and investor-owned utilities

- Wind development community: developers, manufacturers, scientists.

The information provided to these stakeholder groups addresses the following wind energy development market barriers that are prevalent in this region. Each barrier is followed by a detailed description specific to the MWEC region and an example of the MWEC's work to address the barrier with their stakeholders.

Gaps exist in the level of understanding of potential wind project impacts. As wind development expands, more information is becoming available on the local community impacts of wind deployment. However, the general public and local decision-makers often cite a lack of scientifically credible information as an issue. In some cases, this information is available but not readily accessible; in others, the information is not conclusive. Where information does exist, it should be made readily available in a form that is understandable for identified stakeholders. 
RRC members have engaged and educated stakeholders throughout the region, especially in Wisconsin, Minnesota, Illinois, Michigan, Indiana, and Ohio.

\section{Policymakers and the general public have had limited access to economic information pertaining to wind energy. Positive economic impacts from wind development include well-} paying jobs, taxpayer benefits, and lowered rates. Using NREL's Jobs and Economic Development Impacts (JEDI) tool ${ }^{96}$ for estimating the economic impacts of wind projects in various states, MWEC estimated the economic benefits that could accrue to each MWEC state if its wind development achieved the vision in the DOE Wind Vision report. ${ }^{97}$ This information for Iowa, Illinois, Michigan, Minnesota, South Dakota, and North Dakota has been distributed to some local stakeholders and policymakers, and the results for each state are available on the MWEC website. ${ }^{98}$ MWEC is working to disseminate similar information to stakeholders in all of the MWEC states.

\section{Insufficient transmission to tap the wind-rich resources of the region and lower the cost of electricity. Expanding the transmission system will also make it more robust. As discussed earlier in this section, the Rock Island Clean Line and Grain Belt Express Clean Line are in development. In addition, more wind development is underway as a result of the CapX2020 transmission expansion, ${ }^{99}$ which completes the various segments in Minnesota, North Dakota, South Dakota, and Wisconsin. This success story, in which 11 utilities serving the Upper Midwest worked collaboratively to plan, develop, build, expand, and update transmission, began in 2004 and is now close to completion. When the CapX2020 expansion started, many coal plants were proposed as part of utilities' resource plans in the region. Now many of the proposed coal plants are uneconomic and have been removed from the dockets; many others have aged out of use, with several closings announced. Today new wind leases are being offered to farmers as the various segments of the transmission expansion are completed. While this new collaborative model for the region's energy planning was designed with a focus on the whole system and all types of generation, because of timing and other factors, it may be more beneficial to add additional capacity for utility-scale wind generation in parts of the Midwest. Similar to CapX2020, a Midcontinent Independent System Operator (MISO) Multi Value Project, MISO’s continued focus to weigh project reliability, economics, and public policy drivers when making decisions pertaining to Multi Value Projects could make wind a possible addition in certain areas. $^{100}$}

MWEC continues to partner with the organization Wind on the Wires to advance appreciation for the benefits of transmission expansion in the region.

\footnotetext{
${ }^{96}$ https://www.nrel.gov/analysis/jedi/

97 The DOE Wind Vision Report assesses the potential economic, environmental, and social benefits of a scenario in which U.S. wind power supplies 10\% of the nation's electrical demand in 2020, 20\% in 2030, and 35\% in 2050; 
Permitting, zoning, and legislative challenges complicate proposed projects. A multitude of permitting issues can affect wind projects in the MWEC region, ranging from wildlife listings as endangered or threatened, habitat, avian interaction, sound, aesthetics, and safety issues. As an example, laws and regulations for zoning of commercial wind farms from four states-Iowa, Minnesota, Nebraska, and Wisconsin — were found to be inconsistent (Doerr 2015), making it increasingly difficult for companies to work in this wind-rich zone. MWEC works to provide education and outreach about these challenges to stakeholders in the region.

Limited support for small, community, and distributed wind. Net metering regulations continue to face challenges in several states, especially with rural electric co-ops and municipal utilities and where solar is active. The Federal Energy Regulatory Commission ruling that the generation and transmission co-ops that provide power to the nation's retail power co-ops may not impose charges on members who purchase renewable energy makes it possible for larger distributed energy projects to move forward. The Commission made clear, in the first of two rulings, that retail co-ops are required by the Public Utility Regulatory Policies Act (PURPA) to buy power from qualifying facilities that wish to sell renewable energy to them. Their obligation under PURPA supersedes an all-requirements contract with a supplier (Uhlenhuth 2016b), but utilities have resisted by creating barriers to interconnection, charging excess fees, and understating avoided cost. MWEC works to advance small, community, and distributed wind in the region by supporting solutions to better inform these challenges.

\subsection{Collaborating Organizations}

DOE's Regional Resource Centers (RRCs) engage diverse stakeholder groups, disseminate targeted technical information about appropriate wind deployment, and provide forums for constructive dialogue. In addition to credible partners such as universities and state energy offices, RRC leaders identify and engage with strong state champions and include these champions in activities whenever possible. Organizations that have collaborated with the MWEC include Alliance for Sustainable Communities, American Wind Energy Association, Center for Rural Affairs, Dakota Resource Council, Distributed Wind Energy Association, eFormative Options, Energy and Environmental Research Center, Great Lakes Renewable Energy Association, Green Energy Ohio, Illinois Institute for Rural Affairs at Western Illinois University, Illinois State University, IndianaDG, Institute for Local Self Reliance, Intertribal Council on Utility Policy, Iowa Economic Development Authority, Iowa Energy Center, Iowa Environmental Council, Iowa Lakes Community College, Iowa State University, Iowa Wind Energy Association, Juhl Energy, Lawrence Berkeley National Laboratory, Midwest Renewable Energy Association, Minnesota Pollution Control Agency/ Minnesota State Fair, Missouri Energy Initiative, Montana Department of Commerce, NAACP Indiana, Navigant, North Dakota Alliance for Renewable Energy, Ohio Environmental Council, RE-AMP Coalition, REcharge Labs, RENEW Wisconsin, Sand Creek Winds, Small Wind Certification Council, South Dakota Renewable Energy Association, South Dakota Wind Energy Association, and Wind on the Wires.

\subsection{State Updates}

Due to the location of the east-west grid intertie, the MWEC covers wind energy engagement in eastern Montana while the Northwest Wind Resource and Action Center engages with stakeholders in the western part of the state. Since more of the state is covered under the western 
market, discussion of the Montana market is included in Section 6 of this document as part of the Northwest Wind Resource and Action Center’s reporting.

\subsubsection{Illinois}

As of December 2017, Illinois has 4,332 MW of wind installed (American Wind Energy Association 2018). In 2016, the wind industry in the state provided a capital investment of nearly \$8.4 billion and supported 4,001 to 5,000 direct and indirect jobs (American Wind Energy Association 2017a), with some new projects planned. Based on the wind installed as of the end of March 2017, MWEC estimates that wind production paid Illinois landowners lease income of between $\$ 13$ million and \$16 million a year.

Illinois has several geographic advantages for wind. The state has a strong wind resource located near urban centers and can take advantage of exporting energy to eastern markets through the PJM Interconnection. However, wind also faces competition from a strong nuclear sector, and there is often local opposition to new wind developments. New state legislators and regulators may not be aware of the benefits and impacts of wind development. Transmission siting and permitting proceedings are a focus of Wind on the Wires, an MWEC partner.

The state has an ambitious RPS of 25\% renewables by 2025. Nevertheless, financial complexities in the Illinois utility market have historically caused the state to be at high risk to not meet this standard. After years of negotiation, legislators passed the Future Energy Jobs Bill $^{101}$ in December 2016, establishing a pathway for energy development that will allow Illinois to meet the RPS. Language in the bill requires 4 million wind renewable energy credits $(\sim 1,300$ MW) through new projects by 2030. In May 2017, state legislators passed SB0071 ${ }^{102}$ to remove wind-related language from the Future Energy Jobs Bill that would have required developing a wind energy installer certification for utility-scale projects. The Illinois Department of Commerce and Economic Opportunity is updating its analyses to account for the Future Energy Jobs bill and finalizing its report. The MWEC expects Department staff to support renewables and transmission in Illinois as part of the long-term Renewables Resource Plan, which is to be developed by 2018.

The Illinois Governor signed Senate Bill 2612 in August 2016 that extended a sunset provision in an existing law to ensure that rural communities continue to receive annual property tax revenue from wind farms. The legislation will now expire in 2021.

Illinois is also participating in the Wind for Schools project through the engagement of Western Illinois University, with seven school systems installed in the state.

101

http://ilga.gov/legislation/billstatus.asp?DocNum=2814\&GAID=13\&GA=99\&DocTypeID=SB\&LegID=96125\&Se $\underline{\text { ssionID }=88}$

102

http://www.ilga.gov/legislation/billstatus.asp?DocNum=71\&GAID=14\&GA=100\&DocTypeID=SB\&LegID=99528 \&SessionID=91 


\subsubsection{Indiana}

Indiana has 2,117 MW of wind installed at the end of December 2017 (American Wind Energy Association 2018). In 2016, wind energy development accounted for $\$ 4.1$ billion of total capital investment within the state with between 1,000 to 2,000 direct and indirect jobs supported (American Wind Energy Association 2017a). MWEC estimates that the installed wind was generating annual lease payments of between \$5.6 million and \$6.9 million.

Indiana’s General Assembly established a summer study committee to include an examination of wind issues. The committee will focus on wind energy construction in the state; health, safety, and property value impacts; and economic development from wind and potential policies to define conflicts of interest (Sprague 2017). MWEC plans to connect with wind allies to prepare a presentation for this committee.

The Governor signed SB 309, a bill impacting net metering in the state, in May 2017. SB 309 will gradually lower the retail rate for net-metered projects beginning at the end of the year (Kelly 2017).

In January 2017, further legislation was introduced in the state that could impact wind energy development. If passed, HB1597 ${ }^{103}$ will set stringent standards for setbacks, voting procedures regarding new and amended wind ordinances and disclosure requirements to identify potential conflicts of interest involving elected and unelected officials and proposed wind farm developments.

A policy development for small wind in Indiana is the feed-in tariff ${ }^{104}$ offered by Northern Indiana Public Service Co., an investor-owned utility. Applications are being accepted for microwind (3 to $10 \mathrm{~kW}$ ) and intermediate wind (>10-200 kW) in the utility's territory. ${ }^{105}$

Indiana is one of three states in the MWEC region with a renewable energy goal (10\% by 2025) that is voluntary and thus not officially considered an RPS.

\subsection{3 lowa}

Iowa has 7,308 MW of wind installed at the end of December 2017 (American Wind Energy Association 2018). By December 2016, wind development in the state represented a capital investment of nearly $\$ 13.5$ billion and supported between 8,000 and 9,000 direct and indirect jobs (American Wind Energy Association 2017a). In 2016, Iowa's wind provided 36.6\% of all in-state electricity production (American Wind Energy Association 2017a). MWEC estimates that the wind installed at the end of Q12017 generated annual lease payments between \$22 million and \$27 million for Iowa landowners.

Iowa ranks second in the nation for installed capacity, behind Texas (American Wind Energy Association 2017c). One of the primary reasons for this high ranking is that Iowa is the headquarters of MidAmerican Energy, an investor-owned utility owned by Berkshire Hathaway,

\footnotetext{
103 https://iga.in.gov/legislative/2017/bills/house/1597\#document-e1697e33

104 Feed-in tariffs are a policy mechanism used to encourage deployment of renewable electricity technologies. A feed-in tariff program typically guarantees that customers who own an eligible renewable electricity generation facility will receive a set price from their utility for all of the electricity they generate and provide to the grid.

${ }^{105}$ https://www.nipsco.com/our-services/renewable-energy-projects/feed-in-tariff-program
} 
which has been a strong supporter of wind energy. In April 2016, MidAmerican announced its $100 \%$ renewable energy vision. Recent projects will bring the company closer to its goal. These include the 154-MW Adams wind project, as well as the 301-MW Ida Grove and the 250-MW O’Brien project, all completed in 2016. At the end of 2016, 48\% of MidAmerican's generation capacity came from wind. Company officials also announced the 2,000-MW Wind XI project, the largest wind project ever planned in Iowa, to be completed by 2020 (MidAmerican Energy 2017).

In August 2017, Apple announced that it will locate a new data center complex in the state. The company will join Facebook, Google, and Microsoft, all of whom have Iowa data centers.

Governor Kim Reynolds touted the state's lead role in low-cost renewable energy as a key factor in Apple's decision (Boshart 2017).

In addition to the strong industry players, Iowa has a robust wind resource and is in a prime location along the electrical grid to export electricity to other states to the east and south. Wind energy development also enjoys high public acceptance and support from government leaders.

Iowa already produces more electricity than the state needs. The recent and future huge growth in wind capacity means that Iowa will eventually need more transmission lines to continue integrating more power into the grid. One such development, Multi-Value Project 4, was completed in October 2016 (MidAmerican Energy 2016). The 71-mile, 345-kilovolt transmission line will benefit wind energy in the state by optimizing wind generation placement and allowing for regional delivery of renewable energy.

Iowa is home to several wind education programs, including those at Iowa State University and the University of Iowa. Iowa State University was selected to participate in DOE's Collegiate Wind Competition 2018. Iowa Lakes Community College was one of the first colleges in the country to offer a wind technician training program. The Des Moines Area Community College also has an active wind technician training program.

Iowa has a state production tax credit program for small wind farms. Although the program was extended several times during its 12-year run, the Iowa legislature will let it expire at the end of 2017 (Uhlenhuth 2017). This program led to the completion of more than $114 \mathrm{MW}$ of distributed wind generation as of the end of June 2017.

\subsubsection{Michigan}

Michigan has 1,860 MW of wind installed at the end of December 2017 (American Wind Energy Association 2018). By December 2016, wind development in the state represented a capital investment of about \$3.1 billion and supported between 2,000 and 3,000 direct and indirect jobs. Michigan's wind contributes $4.2 \%$ of the in-state electricity production (American Wind Energy Association 2017a). Based on the amount of wind installed as of the end of March 2017, MWEC estimates the annual rate of total lease payments to landowners to be between $\$ 4.8$ million and $\$ 5.8$ million.

In 2016, the state expanded its RPS to require state electricity providers to generate $15 \%$ of their sales from renewable energy sources by 2021. Michigan has potential for offshore wind development. An important development in 2015 was the completion of a new high-voltage 
transmission line to serve the wind turbines in Michigan's Thumb Area. ITC Transmission built this line to enable growth in the renewable energy market.

In May 2017, DTE Energy, the state's largest utility, announced plans to transform its energy portfolio by ceasing all coal generation by 2050. By that point, DTE is expected to transition to an energy portfolio that features $40 \%$ generation from renewable energy, primarily in the form of wind (Matheney 2017).

However, wind development faces obstacles in Michigan. One barrier is the uncertainty of zoning decisions made at the township level. Six communities in the state have moratoriums for wind energy development: Owosso Township, Ellington, Almer, Elmwood, Shiawassee County, and Huron County.

\subsubsection{Minnesota}

Minnesota has 3,699 MW of wind installed as of December 2017 (American Wind Energy Association 2018). In 2016, wind development represented a capital investment of $\$ 6.8$ billion and supported between 3,000 and 4,000 direct and indirect jobs. In 2016, Minnesota wind provided $17.7 \%$ of all in-state electricity production (American Wind Energy Association 2017a). Based on the amount of wind installed as of March 2017, MWEC estimates the annual rate of total lease payments to landowners to be between $\$ 11$ million and \$13 million, with state wind energy production taxes exceeding \$12 million a year. The state also has $134 \mathrm{MW}$ of distributed wind installed (U.S. Department of Energy 2017a), which is the highest in the MWEC region. Minnesota began the 21st century as a leader in Midwestern wind, but even with several new projects planned, wind development has slowed in recent years.

Minnesota has a strong wind resource in the southwestern part of the state. In 2016, Mower County ranked first in the state for wind energy tax revenue, with more than $\$ 2.3$ million, a $26.5 \%$ increase comparative to 2015 totals. Of this amount, $\$ 400,000$ will be used to repair county roads and bridges, while the remainder will be used to provide tax relief to residents (Faircloth 2017). Since 2017, Mower County has received more than \$14.8 million from wind energy tax revenue.

The ongoing CapX2020 transmission line project may allow increased renewable energy development in the near future. Two CapX2020 high-voltage transmission lines, the Brookings County-Hampton and Fargo-St. Cloud-Monticello lines, were brought online in 2015. The Hampton-Rochester-LaCrosse line began transmitting power in September 2016, and the Big Stone South to Brookings County is scheduled to be online in 2017. These two segments will complete the CapX2020 project, which is being heralded as a new model for siting and building transmission (Monti et al. 2016).

Published in April 2017, Great River Energy’s integrated resource plan ${ }^{106}$ calls for $400 \mathrm{MW}$ of wind added through power purchase agreements by 2021 and plans for an additional $600 \mathrm{MW}$ of wind through 2032.

\footnotetext{
${ }^{106}$ http://greatriverenergy.com/wp-content/uploads/2017/04/GRE-2017-IRP-Final.pdf
} 
In recent state legislative activity, Lt. Governor Tina Smith announced an effort in February 2017 to increase the state's renewable energy standard from $25 \%$ by 2025 to $50 \%$ by $2030,{ }^{107}$ but the effort to schedule a hearing at the legislature failed.

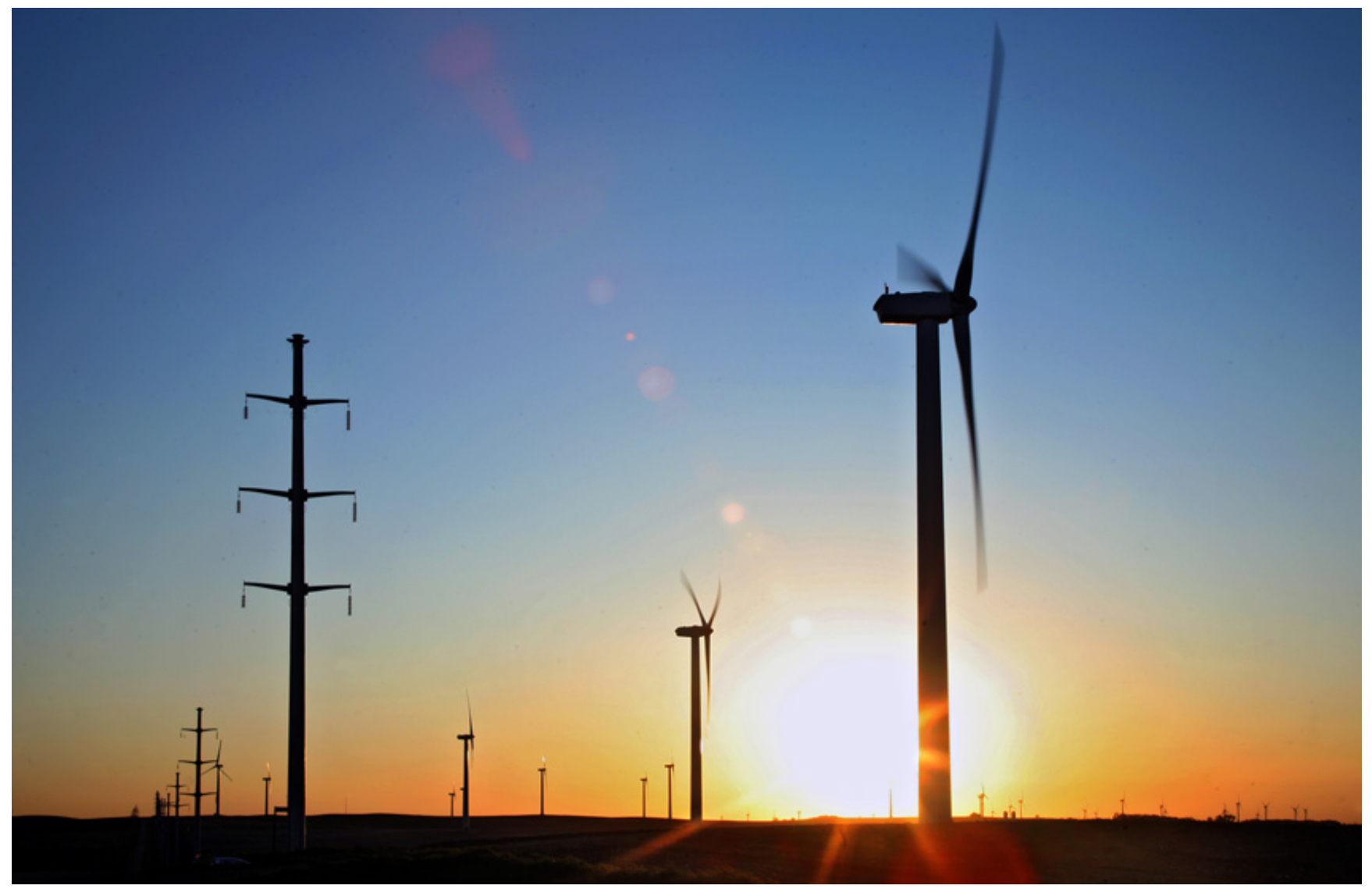

Figure 11. The CapX2020 transmission line involves 11 utilities that serve the Upper Midwest. The project is expected to allow increased renewable energy development in the region. Photo courtesy of CapX2020

\section{MWEC Principal Provides Testimony to lowa Utility Board}

An MWEC principal provided testimony to the lowa Utility Board supporting Interstate Power and Light Company's proposal to expand its wind generation near the town of Hampton by $500 \mathrm{MW}$. The testimony confirmed the capacity factor estimates made by Interstate Power and Light in its proposal, thereby supporting its estimate of the ultimate cost and net benefits of the project for the utility's customers. This supportive testimony helped lead to the project's approval, and construction is slated to begin in spring 2018. According to Hampton Mayor Brook Boehmler, "The City of Hampton appreciates the many opportunities the wind turbines have brought to our community." Karen Mitchell, the county's economic development director, observed that "Harvesting the wind has been nothing but a positive for Franklin County. The economic benefit to the landowners and the county is significant and the jobs created are highly sought after."

\footnotetext{
${ }^{107}$ https://mn.gov/governor/newsroom/\#/detail/appId/1/id/281735
} 


\subsubsection{Missouri}

Missouri has 959 MW of wind installed at the end of December 2017 (American Wind Energy Association 2018). By December 2016, wind development represented a capital investment of about \$1.4 billion and supported between 1,000 and 2,000 direct and indirect jobs. In 2016, Missouri wind provided $1.42 \%$ of all in-state electricity production (American Wind Energy Association 2017a). Based on the amount of wind installed as of March 2017, MWEC estimates the annual rate of total lease payments to Missouri landowners to be between \$1.7 million and \$2 million. Missouri has a strong but underutilized wind resource in the northwestern part of the state.

According to the U.S. Energy Information Administration, 77\% of Missouri's electricity came from coal in 2016, down from 83\% in 2014. Nearly all the coal used for energy generation is imported from Wyoming. ${ }^{108}$ However, Missouri has the potential to increase its energy independence and could even create its own renewable energy export industry. The DOE Wind Vision report ${ }^{109}$ suggests that Missouri could vastly increase its installed wind capacity in the coming decades and has the resource potential to produce as much wind energy as Minnesota and the Dakotas.

New solar initiatives in Missouri may lead the way to more in-state renewable energy development. There has been no new energy legislation, but the regulatory side had a docket in progress for revising the Certificate of Convenience and Necessity rule on transmission lines. Officials for the Grain Belt Express Clean Line transmission project ${ }^{110}$ re-filed an application in August 2016. On August 16, 2017 the PSC denied approval of the project for a third time (Peters 2017). The Missouri Joint Municipal Electric Utility Commission, a public power agency that serves 67 Missouri municipalities, announced that a group of their municipal utility members will buy transmission service on the project, and a few independent municipalities have subsequently followed. The municipalities cited cost savings and diversifying their power portfolios as the primary reasons to participate.

The Ameren Transmission Company of Illinois has been developing the Mark Twain Transmission Project. A certificate of need was granted, the grant was appealed, and the appeal was upheld, after which Ameren announced a new alignment that would use existing rights of way for $90 \%$ of the line. The project gained local approval from involved counties in September 2017, finalizing the planned route. Ameren anticipates PSC approval in early 2018, with project completion tentatively scheduled for December 2019 (Gray 2017).

In September 2017, Ameren Missouri made a significant wind energy development announcement: Ameren will add at least 700 megawatts of wind power at a cost of approximately $\$ 1$ billion. Expected to be complete by 2020, the new wind facilities will be

\footnotetext{
108 https://www.eia.gov/state/?sid=MO

109 The DOE Wind Vision Report assesses the potential economic, environmental, and social benefits of a scenario in which U.S. wind power supplies $10 \%$ of the nation's electrical demand in 2020, 20\% in 2030, and 35\% in 2050; https://www.energy.gov/eere/wind/wind-vision

110 http://www.grainbeltexpresscleanline.com/site/page/location
} 
located in Missouri and neighboring states (Ameren 2017). Published in September 2017, Ameren Missouri's IRP calls for the addition of at least $700 \mathrm{MW}$ of wind generation by $2020{ }^{111}$

Missouri's RPS is $15 \%$ by 2021, but the terms of it are being disputed (Uhlenhuth 2016a).

\subsubsection{North Dakota}

North Dakota has 2,996 MW of wind capacity installed at the end of December 2017 (American Wind Energy Association 2018). In 2016, wind development represented a capital investment of $\$ 5.4$ billion and supported between 4,000 and 5,000 direct and indirect jobs. North Dakota's wind contributed more than $21 \%$ of the electricity generated in-state in 2016 (American Wind Energy Association 2017a). MWEC estimates the annual rate of total lease payments to landowners, based on the amount of wind installed as of March 2017, to be between $\$ 8.5$ million and $\$ 10$ million.

North Dakota has been involved in several multi-state transmission projects in recent years; new projects have been aided by 2015 legislation that extended wind tax credits. A sales and use tax expired at the end of 2016. An interim study committee recommended that the legislature enact a permanent extension in 2017.

The North Dakota legislature adjourned without adopting any of the bills opposing wind energy that were debated this year. These included a 2-year moratorium on wind (SB 2314 ${ }^{112}$ ) and a measure that would have transferred $70 \%$ of local taxes paid by wind farms into the state's general fund (SB 2209 ${ }^{113}$ ). However, the following passed:

- HB 1378, ${ }^{114}$ a bill requiring wind projects, both planned and operating, to install light mitigation technologies

- HB $1181,{ }^{115}$ a bill that modifies wind easements, including the establishment of a 36month window before a landowner can terminate the easement if no operation or construction has begun

- SB $2313,{ }^{116}$ a bill formally requiring a $1.1 \mathrm{x}$ turbine height setback from the property line of non-participating landowners and a $3 x$ turbine height setback from any inhabited residence of a non-participating landowner

- The state budget bill includes a new interim study on wind energy taxation and revenue distribution. ${ }^{117}$

North Dakota has a very strong wind resource, but the state's energy decision makers have been primarily focused on the economic benefits of traditional sources of energy. The state's renewable energy goal (10\% by 2015) is voluntary and was surpassed with approximately $20 \%$ in 2015. No new goals have been set. Energy development impacts to wildlife-especially sage grouse, bats, and a variety of avian species—are a concern in the state.

\footnotetext{
${ }^{111}$ https://www.ameren.com/missouri/environment/integrated-resource-plan

$112 \mathrm{http://www.legis.nd.gov/assembly/65-2017/bill-actions/ba2314.html}$

113 http://www.legis.nd.gov/assembly/65-2017/bill-actions/ba2209.html

$114 \mathrm{http}: / /$ www.legis.nd.gov/assembly/65-2017/bill-actions/ba1378.html

115 http://www.legis.nd.gov/assembly/65-2017/bill-actions/ba1181.html

${ }^{116} \mathrm{http://www.legis.nd.gov/assembly/65-2017/bill-actions/ba2313.html}$

117 http://www.legis.nd.gov/files/resource/committee-memorandum/19.9065.01000.pdf
} 


\subsubsection{Ohio}

Ohio has 617 MW of wind installed at the end of December 2017 (American Wind Energy Association 2018). In 2016, wind development represented a capital investment of about $\$ 1.1$ billion and supported between 2,000 and 3,000 direct and indirect jobs. In 2016, wind energy supplied just over 1\% of Ohio’s electricity (American Wind Energy Association 2017a). MWEC estimates the annual rate of total lease payments to landowners, based on the amount of wind installed as of March 2017, to be between \$1.5 million and \$1.8 million.

Despite many challenges, some wind energy development continues to move forward in the state with the 250-MW Northwest Ohio wind project. DOE continues to provide support for the proposed six-turbine, 20-MW Icebreaker pilot project on Lake Erie under its advanced technology demonstration program for offshore wind. The installation will likely be the nation's first freshwater offshore wind farm.

The Lake Erie Energy Development Corporation project was one of three projects identified by DOE to have demonstrated significant progress toward completion. In May 2016, Icebreaker received a DOE grant of up to \$40 million of funding, subject to progress reviews, to develop the project. Icebreaker was previously selected for a fiscal year 2012 DOE financial assistance award. ${ }^{118}$

The project took significant steps toward construction in August 2017 as DOE, in cooperation with the U.S. Army Corps of Engineers and the U.S. Coast Guard, published a draft environmental assessment of the Icebreaker project ${ }^{119}$ that concluded the development will have no significant environmental impacts. Additionally, the Ohio Power Siting Board held its first public hearing about the project in November 2017. The Ohio Power Siting Board is the agency in charge of issuing a Certificate of Environmental Compatibility and Public Need, the major state permit for the project. Construction is currently planned for Summer 2020 with operation beginning in November of that same year.

Ohio's strong manufacturing sector leads the country in wind-related manufacturing enterprises, with the state hosting 61 active wind-related manufacturing facilities (AWEA 2017). However, recent state energy policy has implications, ultimately discouraging wind project development. In 2014, Ohio became the first state in the nation to place a 2-year freeze on its RPS and energy efficiency standards; this freeze expired on December 31, 2016 and so far has not been renewed. Prior to the reinstitution of Ohio's RPS policy, state legislators passed HB $554^{120}$ in an attempt to change the RPS to a goal instead of a mandate. Governor Kasich vetoed the legislation on December 27, 2016.

Another policy that was implemented in 2014 has increased setback requirements for large wind turbines. House Bill $483^{121}$ required a wind turbine setback of 1,125 feet from the tip of a turbine's blades to the "property line of the nearest adjacent property.” Previously planned

\footnotetext{
118 U.S. Offshore Wind: Advanced Technology Demonstration Projects under Funding Opportunity Announcement Number DE-FOA-0000410, https://eere-exchange.energy.gov/Default.aspx?Search=410

119 https://www.energy.gov/sites/prod/files/2017/08/f35/EA-2045_Draft\%20Environmental\%20Assessment.pdf

120 https://www.legislature.ohio.gov/legislation/legislation-summary?id=GA131-HB-554

121 https://www.legislature.ohio.gov/legislation/legislation-summary?id=GA131-HB-483
} 
developments have been grandfathered, which has enabled two projects to go forward; ecommerce giant Amazon will purchase the power.

While there have been efforts to institute reasonable setbacks, so far those efforts have not been successful. Newly proposed legislation could change that. Senate Bill $184^{122}$ proposes turbine setbacks be measured from "the exterior of the nearest habitable residential structure, if any located on adjacent property" instead of the "property line of the nearest adjacent property" requirement that was established in 2014.

In January 2017, Dayton Power and Light filed a proposed settlement with the Public Utilities Commission of Ohio that included the company retiring the Killen and Stuart coal plants in June 2018 due to economic reasons. According to reports, language within the proposal committed the utility to developing at least $300 \mathrm{MW}$ of solar and wind energy projects in Ohio no later than 2022 (Lillian 2017a). The decision became final in March (Flitter 2017).

Case Western Reserve University in Cleveland has developed a strong offshore wind education collaborative with the Lake Erie Energy Development Corporation offshore wind project.

\subsubsection{South Dakota}

South Dakota has 977 MW of wind capacity installed at the end of December 2017 (American Wind Energy Association 2018). Capital investment through 2016 was about \$2.1 billion, and in 2016 the industry supported between 1,000 and 2,000 direct and indirect jobs. South Dakota's wind contributed more than 30\% of the electricity generated in-state in 2016 (American Wind Energy Association 2017a). MWEC estimates the annual rate of total lease payments to landowners, based on the amount of wind installed as of March 2017, to be between $\$ 2.6$ million and \$3.2 million.

South Dakota utility Butte Electric Cooperative announced significant progress in diversifying its energy portfolio. In 2000, the utility generated $85 \%$ of its energy from coal with an additional $10 \%$ coming from hydroelectric sources. In 2016, this mixture was significantly more diverse, featuring $45.8 \%$ coal, $4.8 \%$ hydroelectric, $18.7 \%$ natural gas and 23.4\% wind energy (Brunner 2016).

MWEC is monitoring the growing local opposition to proposed wind facilities in eastern South Dakota and will continue to engage and educate stakeholders. At least three South Dakota counties have had discussions resulting in moratoriums and/or new regulations pertaining to setbacks: Lincoln (one-half-mile setback), ${ }^{123}$ Hughes (6-month moratorium to study regulations), ${ }^{124}$ and Walworth (2-mile setback). ${ }^{125}$

As described earlier, a significant project is in the planning stages in South Dakota involving a partnership of Native American tribes. Seven Sioux tribes plan to jointly develop their wind

\footnotetext{
122 https://www.legislature.ohio.gov/legislation/legislation-status?id=GA132-SB-184

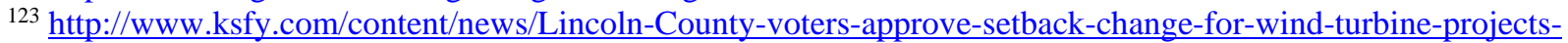
435300773.html

${ }^{124}$ http://www.keloland.com/news/article/news/hughes-county-stalls-wind-farm-projects-to-study-ordinances

125 http://walworthco.org/wp-content/uploads/2010/10/Walworth-County-Zoning-Ordinance-022117-PlanningComission-Approved.pdf
} 
resources. The resulting enterprise has the potential to become one of the largest utility-grade wind installations in the country, generating more than a gigawatt of power and building transmission to sell the power to distant markets. The project can provide economic selfsufficiency and political self-determination for the tribes, which occupy some of the poorest counties in the United States.

South Dakota participates in DOE's Wind for Schools project, with South Dakota State University helping to install six school systems in the state.

\subsubsection{Wisconsin}

Wisconsin had 746 MW of wind installed at the end of December 2017 (American Wind Energy Association 2018). As of December 2016, the industry in the state supports between 1,000 and 2,000 direct and indirect jobs. Wind accounted for $2.35 \%$ of all in-state electricity production in 2016 (American Wind Energy Association 2017a). MWEC estimates the annual rate of total lease payments to landowners, based on the amount of wind installed as of March 2017, to be between $\$ 1.6$ million and \$2 million.

Coal is the state's main source of energy, but utilities in the state have recently been transitioning to cheaper natural gas and other forms of generation. Wisconsin met its RPS of $10 \%$ by 2015 .

One commercial-scale wind project is currently under construction in Wisconsin. The 98-MW Quilt Block project in Lafayette County has a contract to sell power to Dairyland Electric. Dairyland officials have also announced the purchase of an additional $80 \mathrm{MW}$ of wind energy from Avangrid Renewables. Including $20 \mathrm{MW}$ of solar capacity, these additions will increase the renewable energy portion of Dairyland's portfolio from approximately $8 \%$ to more than $20 \%$ in less than 2 years (Hubbuch 2017). This project arrives at the end of a 5-year period of no new wind activity, mostly due to poor public acceptance and politics (WPPI Energy 2016).

In June 2016, Wisconsin Public Power Inc. issued a request for proposals for $100 \mathrm{MW}$ of renewable generation with a preference for it to be built in Wisconsin. The contract was awarded in January 2017 to the Point Beach Solar Energy Center (Murray 2017). In August 2017, Wisconsin Public Power Inc. announced that it would purchase $132 \mathrm{MW}$ from Bishop Hill III Wind Energy Center in Illinois beginning in 2018 (WPPI Energy 2017). The Wisconsin Focus on Energy program historically supported small and distributed wind projects but has been revised under new state leadership. Current funding is allocated for digesters and broadband but does not include incentives for wind.

Although the state has strong laws on wind siting and is well positioned for transmission to load centers, it suffers from public opposition. Individual counties have even defied state regulations on siting. In 2014, Brown County declared wind turbines a public health risk (Srubas 2014). A proposed \$250,000 for a study of health issues related to wind turbines was included in the 2015 state budget. Concerns related to bats and other wildlife also continue to impact development in the state. Wisconsin had a healthy small and distributed wind sector through 2012, but both markets have slowed considerably in recent years. 
The University of Wisconsin-Madison participated in the DOE 2016 Collegiate Wind Competition and 2017 Technical Challenge and was selected to participate in Collegiate Wind Competition 2018.

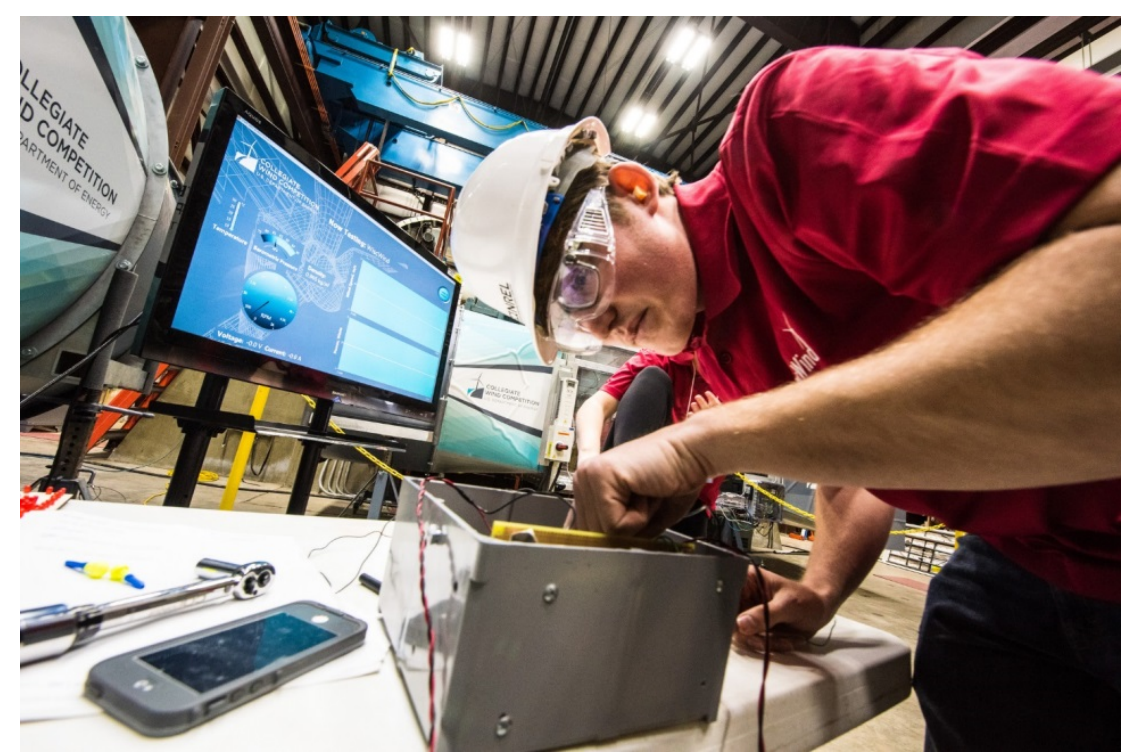

Figure 12. Electronic component connections to the University of Wisconsin-Madison's wind turbine load at the 2017 Collegiate Wind Competition. Photo by Dennis Schroeder, NREL 


\section{Northeast Region}

Colleagues from the Northeast Wind Resource Center (NWRC) and the National Renewable Energy Laboratory (NREL) collaborated to provide the following assessment of the state of the wind industry in this region.

The NWRC ${ }^{126}$ encompasses Connecticut, Maine, Massachusetts, New Hampshire, New Jersey, New York, Pennsylvania, Rhode Island, and Vermont (see Figure 4). ${ }^{127}$ The NWRC spans offshore and land-based wind energy development at the commercial and community scale through interstate cooperation, information sharing, education, stakeholder engagement, knowledge transfer, and community dialogue. Clean Energy Group leads the offshore and landbased wind work; Sustainable Energy Advantage, LLC provides support as needed on the landbased wind work. The Maine Ocean and Wind Industry Initiative serves as a key liaison between the project and the wind industry. The NWRC is built on previous stakeholder engagement and educational activities, including the New England Wind Energy Education Project, the New England Wind Forum, and current projects such as the Offshore Wind Accelerator Project. ${ }^{128}$

\subsection{Overview of Regional Wind Market}

The challenges and opportunities for wind energy development in the region vary from state to state. In addition, land-based wind and offshore wind face different challenges. Some of landbased wind's biggest challenges across the region are development concerns, project siting, and - especially in the northern areas — interconnection to the grid, while offshore wind's major challenges include cost, infrastructure, and regulatory barriers. Land-based wind in the region is expected to expand in the latter years of this decade, dependent not only on permitting and financing but also on transmission expansion and renewable energy certificate off-take contracts. Offshore wind projects are expected to be online by 2025.

Because of the Northeast's population density and land use and ownership patterns, communityscale and larger installations face unique challenges to development. More communities across the region are adopting strict zoning regulations or outright bans on land-based commercial wind installations and met towers. When doubt and uncertainty enter the debate, decision makers may revert to the status quo (i.e., no wind project). Projects that progress beyond initial proposals are subject to potentially significant hurdles due to permitting appeals and lawsuits.

All states in the NWRC area have policies that incentivize clean energy development. However, barriers to developing wind exist, including transmission constraints, lack of power purchase agreements, developers' financial challenges, and uncertain federal tax policy. The factors make siting and building projects, even appropriately located ones, progressively more challenging. Developers, some with long-term power purchase agreements, are stepping away from some proposed projects. After significant wind-generated capacity was added in northern Maine over the past decade, transmission constraints have caused land-based wind developers in Maine to put construction on hold.

\footnotetext{
126 http://www.northeastwindcenter.org/

${ }^{127}$ Island communities in coastal Maine, Massachusetts, and Rhode Island are represented by the Islanded Grid Resource Center.

${ }^{128}$ http://www.cesa.org/projects/accelerating-offshore-wind-owap/
} 
New York has 1,829 megawatts (MW) of wind, although only around $100 \mathrm{MW}$ have been built since 2012. Developers have requested permits for approximately 1,958 MW of land-based wind projects from the New York Department of Public Service under Article 10. Pennsylvania, with more than 1,369 MW of wind as of December 2017 and no projects under construction, has many areas with a good wind resource and lower population density. Stakeholders can consult the U.S. Department of Energy's (DOE's) interactive Wind Vision Study Scenario Viewer ${ }^{129}$ to learn more about state-specific costs, benefits, and other impacts from wind energy development related to the Wind Vision scenarios. The high cost of offshore wind energy, a complex permitting process, and political opposition are major barriers to offshore wind development in the Northeast. The 30-MW Block Island Wind Farm in Rhode Island is America's first offshore wind farm and demonstrates that these challenges can be overcome. The following section provides an overview of the wind industry in the region.

Table 15. Key Statistics for States in the Northeast Wind Resource Center Region

\begin{tabular}{|c|c|c|c|c|c|c|c|c|c|}
\hline & CT & ME & MA & NH & NJ & NY & PA & RI & VT \\
\hline $\begin{array}{l}\text { Installed Wind (MW), End } \\
\text { of } 4 \mathrm{Q} 17^{130}\end{array}$ & 5 & 923 & 115 & 185 & 9 & 1,829 & 1,369 & 54 & 149 \\
\hline $\begin{array}{l}\text { Percentage of In-State } \\
\text { Energy Production, End of } \\
2016^{131}\end{array}$ & $0 \%$ & $13.9 \%$ & $.7 \%$ & $2.3 \%$ & $0 \%$ & $2.9 \%$ & $1.6 \%$ & $.5 \%$ & $15.4 \%$ \\
\hline $\begin{array}{l}2017 \text { Wind Power Capacity } \\
\text { Additions (MW) }{ }^{132}\end{array}$ & 0 & 23 & 8 & 0 & 0 & 1.5 & 0 & 1.5 & 30 \\
\hline $\begin{array}{l}\text { Wind Capacity under } \\
\text { Construction (MW) }\end{array}$ & 0 & 0 & 2 & 0 & 0 & 158 & 0 & 0 & 0 \\
\hline $\begin{array}{l}\text { Projected Potential } \\
\text { Capacity (MW), } 80 \text { m, } \\
\text { 30\% Capacity Factor }\end{array}$ & 27 & 11,251 & 1,028 & 2,135 & 132 & 25,781 & 3,307 & 47 & 2,949 \\
\hline $\begin{array}{l}\text { Projected Potential } \\
\text { Capacity (MW), } 100 \text { m, } \\
\text { 30\% Capacity Factor }\end{array}$ & 186 & 30,847 & 1,913 & 3,919 & 349 & 57,639 & 7,222 & 84 & 5,637 \\
\hline $\begin{array}{l}\text { Distributed Wind Capacity, } \\
\text { as of December } 2016 \\
(\mathrm{MW})^{134}\end{array}$ & 5.1 & 5.4 & 78.9 & 0.2 & 9.1 & 10.6 & 3.3 & 24.1 & 10.9 \\
\hline
\end{tabular}

Sources: American Wind Energy Association, U.S. DOE

129 http://en.openei.org/apps/wv_viewer/

130 American Wind Energy Association 2018

${ }^{131}$ American Wind Energy Association 2017a

132 American Wind Energy Association 2018

133 American Wind Energy Association 2018

134 Distributed wind project capacity is defined as cumulative capacity, 2003-2016 (U.S. Department of Energy 2017a). 


\subsubsection{Renewable Portfolio Standards}

In the NWRC's region, all nine states have a renewable portfolio standard (RPS) (Table 16). New York State finalized a Clean Energy Standard requiring public utilities to procure $50 \%$ of the state's electricity from eligible clean energy sources by 2030 as part of Governor Cuomo's Reforming the Energy Vision process. In June 2016, Rhode Island's Governor Raimondo signed into law an extension of the current RPS. Rhode Island's RPS will continue until it reaches $40 \%$ by 2035, a significant increase over the previous target of $19.5 \%$ by 2019 .

Some states have goals specifically for wind energy. Through the 2010 Ocean Energy Act ${ }^{135}$ that encourages ocean wind development, Maine adopted wind goals of at least 3,000 MW of installed capacity by 2020 (300 or more from offshore wind) and 8,000 MW of installed capacity by 2030 (5,000 or more from offshore wind). New Jersey also has targets for offshore wind power $(1,100 \mathrm{MW})$.

Table 16. RPS Overview for States Served by the Northeast Wind Resource Center

\begin{tabular}{|c|c|}
\hline & RPS \\
\hline Connecticut & $27 \%$ x 2020 (Class I: $20 \%$, Class I/II: $3 \%$, Class III: 4\%) \\
\hline & $40 \%$ of net electricity sales by 2017 \\
\hline Maine & New renewable energy: $10 \%$ x 2017 \\
\hline Massachusetts & $22.1 \%$ x 2020 (Class I: 15\%, Class II: 7.1\%) (+1\% annually after) \\
\hline & $24.8 \% \times 2025$ \\
\hline New Hampshire & New renewable energy: 15\% x 2025 \\
\hline New Jersey & $\begin{array}{l}20.38 \% \text { renewable energy } \times 2021 \\
+4.1 \% \text { solar } \times 2028\end{array}$ \\
\hline New York & $50 \% \times 2030$ (as part of Clean Energy Standard) \\
\hline Pennsylvania & $18 \% \times 2021$ (include non-renewable alternative resources) \\
\hline Rhode Island & $40 \% \times 2035$ \\
\hline Vermont & $55 \%$ by 2017 and $75 \%$ by 2032 \\
\hline
\end{tabular}

Source: Database of State Incentives for Renewables \& Efficiency

\subsubsection{Communities with $100 \%$ Renewable Energy Commitments}

Many state public utility commissions are working with utilities to choose the direction of their energy portfolios. While some states have mandated and voluntary renewable energy goals or standards, some cities have gone a step further to create their own commitments to clean energy, some of which exceed levels established by their states. Five communities within the Northeast region have made $100 \%$ renewable energy commitments (Table 17).

${ }^{135}$ http://www.mainelegislature.org/legis/bills/bills_124th/chappdfs/PUBLIC615.pdf 
Table 17. Communities Served by the Northeast Regional Resource Center with $100 \%$ Renewable Energy Commitments

\begin{tabular}{lll}
\hline City & State & Target Year \\
\hline Burlington & VT & Achieved in 2014 \\
Cambridge & MA & 2035 \\
East Hampton & NY & 2020 \\
Hanover & NH & 2030 \\
Southampton & NY & 2025 \\
\hline
\end{tabular}

Source: Sierra Club

\subsubsection{Regional Procurement}

The six New England states have begun to coordinate clean energy procurement to take advantage of economies of scale and spur the construction of needed transmission investments. State agencies and distribution companies in Massachusetts, Connecticut, and Rhode Island issued a Clean Energy Request for Proposals (RFP) ${ }^{136}$ in November 2015.

Under the joint solicitation, Massachusetts' distribution companies, Connecticut Department of Energy and Environmental Protection, and National Grid in Rhode Island sought to procure a combination of Class I RPS renewables, large hydropower, and supporting transmission facilities under long-term contracts or Qualified Clean Energy Delivery Commitments under various existing authorities (detailed below, where relevant). Bids were submitted in January 2016; 23 responses included various combinations of land-based wind, utility-scale solar, fuel cell, and large-scale hydroelectric supply, many combined with supporting transmission proposals. No offshore wind project bids were submitted.

In October 2016, the soliciting parties made their final determinations on all submitted bids. Land-based wind projects selected under the RFP represent approximately $155 \mathrm{MW}$. The landbased wind projects are sited in New Hampshire and New York. Siting challenges, availability of transmission, interconnection delays, and timing of delivery were major factors considered during bid evaluation. It is possible that the currently backed-up ISO-New England ${ }^{137}$ interconnection queue caused evaluators to prefer bids that did not require new transmission capacity to reduce risk and the probability of selected projects dropping out. Contracts with the selected bidders are now subject to regulatory approval in Massachusetts, Rhode Island, and Connecticut.

\subsubsection{Regional Transmission and Interconnection}

Transmission capacity is constrained, and expanded transmission will be necessary to carry any significant future land-based wind development from the northern windy areas of the region to the load centers mostly located in the southern areas. In addition, interconnection remains a significant barrier to wind development. In ISO-New England, for example, there is a backlog in the interconnection queue of more than 3,800 MW of wind projects located in northern New

\footnotetext{
136 https://cleanenergyrfp.com/

137 An independent, non-profit Regional Transmission Organization that serves Connecticut, Maine, Massachusetts, New Hampshire, Rhode Island, and Vermont
} 
England for which review has not yet started. Some projects have power purchase agreements with contractual development milestones that are threatened by the lack of movement on interconnection applications. Representatives from the independent system operators in New England and New York are working with stakeholders on interconnection procedures with the goal of addressing these backlogs and delays.

ISO New England has proposed a clustering methodology to address the interconnection backlog. The proposed clustering methodology would allow two or more interconnection requests to be analyzed in the same system impact study and would allow the projects to share costs related to transmission upgrades and interconnection. No changes will be made to other existing service products, dispatch, and market structures as a result of clustering. The clustering proposal needs Federal Energy Regulatory Commission approval to proceed (ISO-New England 2016).

Several transmission projects have been proposed, including Maine Green Line (wind from Maine/Canada to Massachusetts), Clean Power Link (wind from Canada to the Vermont/New England market), Northeast Energy Link (wind from Maine to Massachusetts), the Maine Power Express (wind from Maine to Massachusetts), and the Empire State Connector (Upstate New York to New York City). The three-state RFP mentioned above also received responses from other transmission projects, each one including wind-based generation as a portion of the transmission. Other proposed transmission projects in the region include the Clean Energy Connect, Vermont Green Line, Maine Renewable Energy Interconnect, and Maine Clean Power Connection. Most of these projects would carry wind and hydropower from the Quebec region.

The needed infrastructure to interconnect offshore wind farms to onshore substations is potentially costly and may require significant upgrades and modifications to substations before they can accept output. At least two options for developing offshore wind transmission are being explored: 1) each developer would be responsible for developing its own transmission to shore, and 2) a third-party developer would develop the transmission to shore. Anbaric Transmission, the developer in charge of the Bay State Offshore Wind Transmission system, proposed a thirdparty independent transmission development: an expandable transmission network for offshore wind in Massachusetts.

In contrast, developer Deepwater Wind took direct responsibility for transmission when developing the 30-MW Block Island offshore wind farm, laying the export cable from the offshore wind farm directly to a new National Grid 34.5-kV substation on Block Island. During the island's "off season," a new 25-mile subsea cable also owned by National Grid will transmit the energy to the mainland electric grid. Deepwater Wind will sell the electricity through a contract to National Grid.

Other proposed transmission lines for offshore wind within the region include the Bay State Offshore Wind Transmission System and the Atlantic Wind Connection, a proposed high-voltage offshore transmission system along the North Atlantic Coast. Key objectives of the Atlantic Wind Connection are to improve grid reliability and resiliency and to provide an efficient and cost-effective transmission of offshore wind power to onshore substations. 


\subsection{Workforce Development}

Several institutions provide wind energy education in the region, including Pennsylvania State University, University of Massachusetts Amherst and Lowell, University of Delaware, University of Maine, Massachusetts Institute of Technology, Cornell University, and Cape Cod Community College. Educational activities are described in more detail in the state sections below. The WINDExchange website also offers information and interactive maps regarding workforce development, the U.S. Department of Energy's (DOE's) Collegiate Wind Competition, DOE's Wind for Schools project, school wind project locations, and locations of education and training programs in the NWRC region and other states. ${ }^{138}$

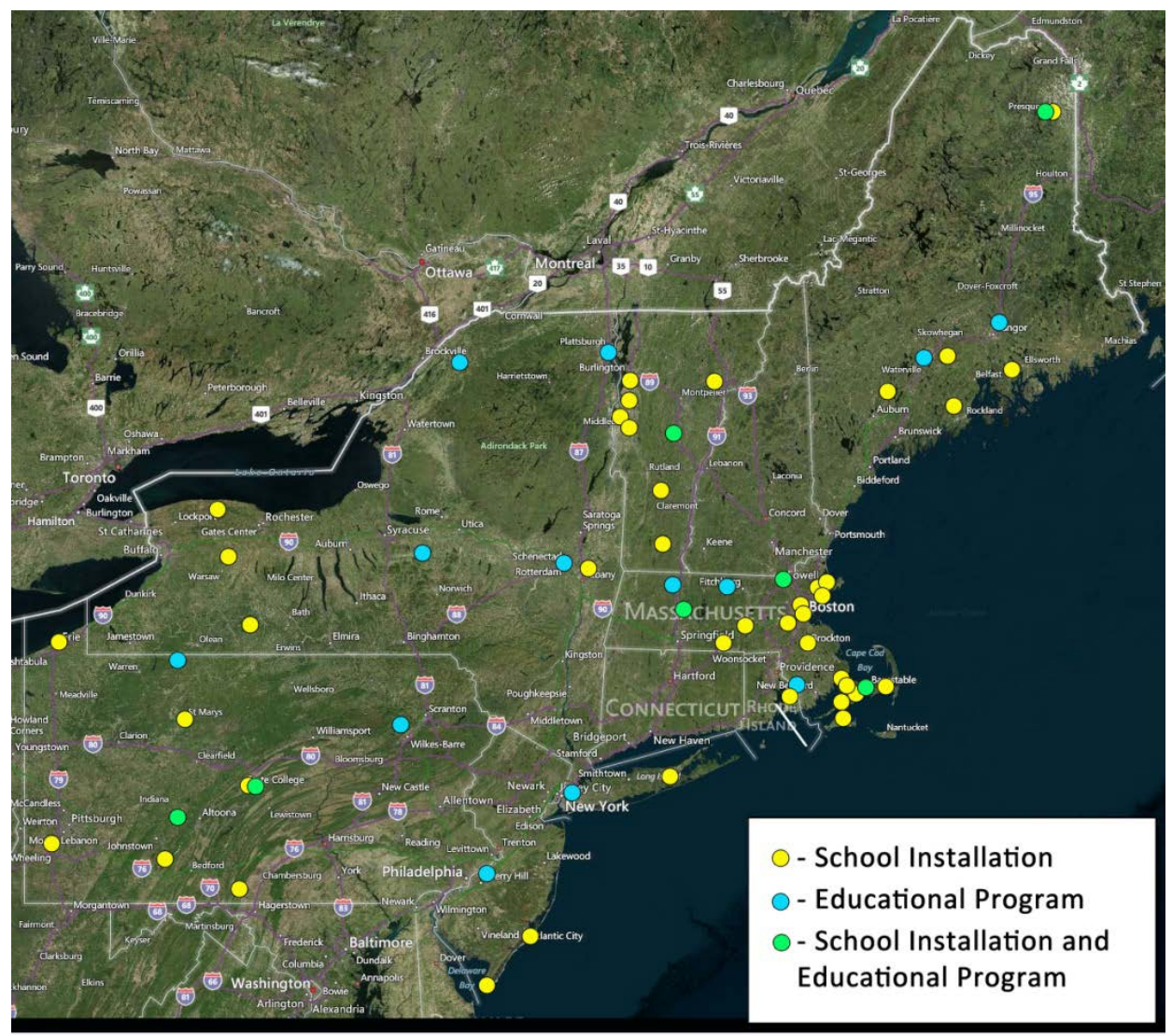

Northeast Wind Resource Center

(ME, VT, NH, MA, CT, RI, PA, NY, NJ)

Figure 13. Map of school wind turbine projects, educational programs, and locations with both wind turbines and educational programs within the Northeast Wind Resource Center's area

\subsection{Manufacturing and Economic Development}

NREL researchers compiled the following wind energy manufacturing data for this region as part of DOE’s annual wind market report effort (U.S. Department of Energy 2017c).

138 https://windexchange.energy.gov/education-workforce 
Table 18. Wind-Related Manufacturing Overview for States Served by the Northeast Wind Resource Center

\begin{tabular}{llll}
\hline Name & City & State & Component \\
\hline General Cable & Tolland & CT & Cable \\
\hline BJA Magnetics & Rutland & MA & Magnetics \\
\hline Second Wind & Somerville & MA & Anemometers, controllers, sensors \\
\hline Pika Energy & Westbrook & ME & Distributed wind \\
\hline Hendrix Wire and Cable & Milford & NH & Cable systems \\
\hline Mersen USA & Boonton & NJ & Carbon brushes, sliprings \\
\hline Rotor Clip Company & Somerset & NJ & Retaining rings \\
\hline loxus & Oneonta & NY & Ultracapacitors \\
\hline Weaver Wind Energy & Freeville & NY & Distributed wind \\
\hline Ellwood Group & Irvine & PA & Main shaft bearings \\
\hline Hodge Foundry & Greenville & PA & Component castings \\
\hline Nord-Lock & Carnegie & PA & Fasteners \\
\hline Vacon Inc. & Chambersburg & PA & A/C drives \\
\hline Superbolt Inc. & Carnegie & PA & Fasteners \\
\hline Windurance & Seneca & PA & Pitch control systems \\
\hline Applied Bolting Technology & Bellows Falls & VT & Bolts \\
\hline Northern Power Systems & Barre & VT & Distributed wind \\
\hline
\end{tabular}

Additional economic impacts from wind development include the capital investment, jobs supported, tax revenues paid, payments in lieu of taxes, and land lease payments made by wind developers during construction and the ongoing maintenance of wind plants. The American Wind Energy Association performs modeling work that identifies the impacts of all wind-related investment. Table 19 summarizes the total jobs (including construction jobs in 2016) and capital investment in wind farms in the NWRC states. Examples of economic impacts are provided in the state overviews below. 
Table 19. Economic Impacts of Wind Development in States Served by the Northeast Wind Resource Center

\begin{tabular}{lll}
\hline State & Direct and Indirect Jobs Supported & Total Capital Investment \\
\hline Connecticut & $1-100$ & $\$ 9$ million \\
\hline Maine & $1,001-2,000$ & $\$ 1.8$ billion \\
\hline Massachusetts & $501-1,000$ & $\$ 236$ million \\
\hline New Hampshire & $101-500$ & $\$ 374$ million \\
\hline New Jersey & $501-1,000$ & $\$ 15$ million \\
\hline New York & $1,001-2,000$ & $\$ 3.7$ billion \\
\hline Pennsylvania & $1,001-2,000$ & $\$ 2.8$ billion \\
\hline Rhode Island & $101-500$ & $\$ 344$ million \\
\hline Vermont & $101-500$ & $\$ 253$ million \\
\hline
\end{tabular}

Source: American Wind Energy Association 2017, as of 2016

\subsection{Key Stakeholder Groups and Development Challenges}

The NWRC targets these stakeholder groups:

- For offshore wind, the NWRC is focused on state clean energy funds and the public utility commissions as its primary stakeholders.

- For land-based wind, the NWRC focuses on state and local policymakers, media, and members of the public.

- Through its industry partner the Maine Ocean Wind Industry Initiative, some offshore wind outreach is provided to industry stakeholders and the general Maine public.

The information provided to these stakeholder groups addresses the following wind energy development market barriers that are prevalent in this region. Each barrier is followed by a detailed description specific to the NWRC region and an example of the NWRC's work to address the barrier with its stakeholders.

Lack of acceptance of offshore wind energy development continues to stall many projects. Community opposition and lengthy litigation battles were the main obstacles for the proposed Cape Wind Project off Massachusetts.

The Islanded Grid Resource Center reported that communities in coastal New England pursuing offshore wind projects face many development challenges, including navigating the regulatory process; addressing technical issues related to installation, interconnection, and operation; researching and mitigating environmental impacts; interacting with other human uses; and general acceptance. However, the 30-MW Block Island Wind Farm has garnered national attention and captured the public's interest. Not only have environmental and energy advocates organized tours for government officials, funders, labor unions, and ocean communities, but also Block Island Ferry offers weekly tours to the public. 
High costs and permitting of offshore wind. Offshore wind projects face high costs due to construction, installation, and operation at sea, as well as necessary modifications to turbines and foundations. Infrastructure barriers include transmission challenges, lack of deepwater ports, lack of specialized installation vessels, a workforce with limited experience, and a nascent supply chain. Complex permitting, lengthy site selection and leasing processes, and uncoordinated planning (jurisdiction by jurisdiction) pose challenges, adding to project cost and development uncertainty.

The NWRC provides information on the high costs of offshore wind, the opportunities for cost reductions, and Europe's experiences with cost reductions. The NWRC gears its information and outreach to the Clean Energy States Alliance's state clean energy fund members, facilitating dialogue on procurement targets, regional financing, alternative financing through green banks and bonds, and regional supply chain development, all means to potentially reduce total project costs.

Land-based wind stakeholder groups require information in the form of presentations, publications, guidelines, and other materials that can aid sound decision-making when considering new policies or wind project proposals. The NWRC is addressing this challenge through several means, including hosting webinars on important wind siting topics such as wildlife impacts, developing and distributing summaries of technical reports about land-based wind, distributing regular newsletters, and compiling information resources on its website. The topics covered in the land-based wind materials include wind physiological and environmental impacts along with technical, economic, financial, and operational issues.

\subsection{Collaborating Organizations}

RRCs engage diverse stakeholder groups, disseminate targeted technical information about appropriate wind deployment, and provide forums for constructive dialogue. In addition to credible partners such as universities and state energy offices, RRC leaders identify and engage with strong state champions and include these champions in activities whenever possible. Organizations that have collaborated with the NWRC include Cape and Islands Self Reliance; Cape and Vineyard Electric Cooperative; Consensus Building Institute; Lawrence Berkeley National Laboratory; Massachusetts Clean Energy Center; Maine Governor's Energy Office; New York State Energy Research and Development Authority (NYSERDA); Rhode Island Office of Energy Resources; Southeast Coastal Wind Coalition; UMass Wind Energy Center; Union of Concerned Scientists; University of Rhode Island; and Vineyard Electric Co-op.

\subsection{State Updates}

\subsubsection{Connecticut}

By the end of 2017, Connecticut had 5 MW of installed wind capacity with no new projects under construction (American Wind Energy Association 2018). As of 2016, total capital investment in wind energy in the state is $\$ 9$ million, and the industry supports fewer than 100 direct and indirect jobs (American Wind Energy Association 2017). The state is moving toward initiatives on regional procurement of clean energy resources in collaboration with other states. Connecticut, Massachusetts, and Rhode Island issued the New England Clean Energy RFP, to which utility-scale wind developers responded. Land-based wind projects selected under the RFP 
represent approximately 155 MW. The land-based wind projects are based in New Hampshire and New York. Siting challenges, interconnection delays, and timing of delivery were major factors considered during bid evaluation and probably contributed to the fact that only two landbased wind projects were selected.

In 2014, the approval of wind siting guidelines ended an effective moratorium on wind development. After a long legal battle, construction began on Connecticut's first commercial wind turbines in 2015, and the project was finished by the fall. BNE Energy developed the Colebrook South Project, which consists of two turbines (Boughton 2015). In October 2016, the Connecticut Department of Energy and Environmental Protection selected a proposed third turbine under a broader RFP that sought proposals from distributed generation projects between 2 and $20 \mathrm{MW}$. Under this RFP, the Connecticut Department of Energy and Environmental Protection selected about $44 \mathrm{MW}$ of land-based wind, spread across multiple projects in multiple New England states.

Massachusetts' draft RFP for offshore wind procurement included a provision that would allow Connecticut to participate in the procurement as well.

The Connecticut Department of Energy and Environmental Protection is updating its Comprehensive Energy Strategy. The update includes strategies for securing cheaper, cleaner, more reliable energy options for buildings, electricity, and transportation. The last Comprehensive Energy Strategy was released in 2013.

\subsubsection{Maine}

With 923 MW of installed wind capacity at the end of December 2017 (American Wind Energy Association 2018), Maine is the regional leader in wind power development for New England. As of the end of 2016, wind power provides $14 \%$ of the state's total electricity supply (American Wind Energy Association 2017a). There are approximately 4,400 MW of wind projects that are in the permitting phase or feasibility phase of development, most of which are awaiting action in the independent system operator's interconnection queue. Total capital investment as of the end of 2016 is $\$ 1.8$ billion, and the wind industry in the state supports between 1,000 and 2,000 direct and indirect jobs (American Wind Energy Association 2017a). The development of community-scale wind projects has slowed in recent years due to issues such as interconnection challenges and the competitive pricing of alternative renewables such as solar. Wind projects that recently began operating include Bingham Wind (the state's largest wind farm to date) and Hancock Wind.

The fate of several previously announced projects under development by SunEdison is uncertain given the company's recent bankruptcy announcement. The 72-MW Weaver Wind project was withdrawn. The West Range (also called Fletcher Mountain) wind project was also withdrawn from the independent system operator's interconnection queue. Bowers Wind (48 MW) is not expected to move forward after losing a court appeal. Several other projects are facing extended development timelines or suspension due to legal, permitting, contracting, and investment setbacks, including Highland Wind, which is proposed in an area that was removed from Maine's expedited wind permitting area (see below on the expedited wind permitting area). Permitting issues associated with visual and species impacts have also emerged. 
EDP Renewables' Number Nine Wind Farm was one of two projects selected by the Connecticut Department of Energy and Environmental Protection under a competitive procurement pursuant to Section 6 of Public Act 13-303, which authorized the agency to seek new Class I renewable energy resources up to $4 \%$ of the state's load under power purchase agreements up to 20 years. The company withdrew its application and power purchase agreement with Connecticut utilities due to interconnection delays. It would have been Maine’s largest wind project, with more than 100 turbines. It was also the largest advanced Class I RPS-eligible project in the region's development pipeline to have an active power purchase agreement.

Maine established an expedited wind permitting area in 2008 to allow for an easier permitting process for wind projects being developed in unorganized territories in the state (Public Law 2007, Ch. 661). In 2015, the Maine Legislature passed a subsequent law allowing residents to petition for the removal of towns/townships/plantations from the expedited permitting area (Public Law 2015, Ch. 265). Removal from the expedited permitting area effectively makes wind development more difficult and requires a more in-depth permitting process for projects. Between January 1 and June 30, 2016, the Maine Land Use Planning Commission accepted petitions for removal of towns/townships/plantations from the expedited wind permitting area. More than 40 petitions for removal were submitted, the majority of which have since been approved.

\section{NWRC Hosts Wind Forum in Portland, Maine}

The Northeast Wind Resource Center, in partnership with E2Tech and the Maine Ocean and Wind Industry Initiative, hosted a half-day wind forum in Portland, Maine, to discuss offshore and landbased wind power on national, regional, and state levels. More than 150 people attended the forum on June 9, 2017, which included presentations by developers, federal agencies, transmission operators, and renewable energy organizations.

NREL's Suzanne Tegen provided a comprehensive overview on the status of wind deployment across the United States, as well as the economic impacts from wind development. Alan McBride from ISO-New England described the organization's proposed new interconnection process and the challenges facing the New England grid, especially in northern New England. ISO-New England's proposed solution, which has been submitted to the Federal Energy Regulatory Commission, is a regional clustering proposal that would cluster groups of generators to achieve economies of scale. Jeremy Payne, executive director of the Maine Renewable Energy Association, presented on the state of wind energy in Maine and said that the clustering proposal could help restart stalled projects. Uncertainty over the permitting and interconnection of northern Maine wind farms, for example, may have led to the selection of fewer wind bids in the New England Clean Energy RFP (with Massachusetts, Rhode Island, and Connecticut).

The morning ended with a developers' panel that discussed land-based wind investments and offshore wind opportunities. Developers fielded audience questions regarding investments in and economic development opportunities for rural Maine and how states can work together to build an offshore wind supply chain. Presentations and a recording of the day's event are archived at http://e2tech.org/event-2548886.

Notably, areas that contain previously permitted or formally proposed wind projects are ineligible for removal, so this proceeding should not have an effect on such projects. However, some projects in the early planning stages that have not yet submitted applications or received permits may be affected by the removal of these townships from the expedited permitting area. 
Projects that may be impacted include West Hills Wind (in Highland, Lexington, Concord, and Pleasant Ridge) and Highland Wind (in Highland), as well as an early-stage project in Trescott Township.

In 2014, the Maine Public Utilities Commission approved a term sheet for the Aqua Ventus 12MW project, calling on the offshore pilot project to sell electricity to Central Maine Power for 23 cents per kilowatt-hour. As of December 2017, DOE has provided \$10.7 million to UMaine for design, development, and permitting activities related to Aqua Ventus I. Project partners include Emera Inc., Cianbro Corporation, University of Maine and the Advanced Structures and Composites Center, and DCNS.

In June 2016, the project was selected for another round of funding from DOE's Advanced Technology Demonstration Program for Offshore Wind. This means that Aqua Ventus I is eligible for an additional \$39.9 million in funding from DOE as long as the project continues to meet established milestones, bringing total DOE funding for the project up to as much as \$50 million. As part of this funding, project developers will be required to contribute a minimum of $50 \%$ of the total project costs.

The project faced challenges over the past year. In April 2017, a bill was proposed in the Legislature (L.D. 1262) ${ }^{139}$ as a result of lobbying efforts by Protect Monhegan, a group of islanders opposed to the project who wish to see the project site moved farther offshore. However, a 2016 survey $^{140}$ showed that most residents responded to the potential project favorably. The state senate rejected the bill in May 2017.

Earlier this year, the Maine Aqua Ventus team and DOE held several public scoping sessions ${ }^{141}$ in Tenants Harbor, St. George, and Monhegan Island. The public scoping sessions provided information on DOE's role in the proposed project, the proposed scope of the Environmental Assessment and alternatives, and the DOE National Environmental Policy Act process. These information sessions yielded information on issues and resources that the DOE should consider when developing the Environmental Assessment. Once the draft Environmental Assessment is posted for public review, there will be another 30-day public comment period.

The University of Maine, meanwhile, is continuing work on project design, operation and maintenance, grid interconnection, and financial plans, and hopes to complete these tasks in 2017. Initial platform construction may begin in 2018, with commercial operation planned for 2019.

\subsubsection{Massachusetts}

At the end of December 2017, Massachusetts had 115 MW of installed wind capacity (American Wind Energy Association 2018). At the end of 2016, wind generation was equal to $0.7 \%$ of instate energy production. Total capital investments are \$236 million as of 2016, and the wind industry in the state supports between 100 and 500 direct and indirect jobs (American Wind

\footnotetext{
139 http://legislature.maine.gov/LawMakerWeb/summary.asp?LD=1262

140 http://www.monheganenergy.info/wp-content/uploads/2016/07/METF-Survey-3-Report_FINAL.pdf

141 https://energy.gov/nepa/office-nepa-policy-and-compliance
} 
Energy Association 2017a). The 8-MW Future Generation Wind project in Plymouth came online in 2016 (Mass Energy Consumers Alliance 2016).

In 2017, Massachusetts legislators introduced Bill S.1849: An Act Transitioning Massachusetts to $100 \%$ Renewable Energy. ${ }^{142}$ If passed, Massachusetts will be powered by $100 \%$ clean, renewable energy by 2050 .

The Massachusetts Clean Energy Center approved up to $\$ 1.8$ million in relief assistance for the Town of Falmouth to financially assist the municipality as it attempts to navigate the impacts associated with reduced operations of the town's two-turbine wind project. Community concerns surrounding sound impacts led to curtailment and unanticipated costs (Massachusetts Clean Energy Center 2014).

${ }^{142}$ https://malegislature.gov/Bills/190/SD1932 


\section{Wind Blade Challenge and Wind Storm Challenge}

The Maine Composites Alliance, the Maine Ocean and Wind Industry Initiative, and the University of Maine's Advanced Structures and Composites Center hosted the Maine Wind Blade Challenge and Windstorm Challenge on May 19, 2017, at the University of Maine's Advanced Structures and Composites Center.

The Maine Wind Blade Challenge is an annual event for the past 9 years. This challenge requires students to connect with composite-manufacturing companies to construct and infuse a functional set of wind blades. Each team's goal is to manufacture an assembly that will generate the most energy in 3 minutes or fewer. Each team is also required to present to a panel of judges on what they have learned, including the science behind wind blade design, composite manufacturing, and how innovation engineering helped them with their process.

The Windstorm Challenge was held simultaneously in the University of Maine's Advanced Structures and Composite Center's Alfond W2 Ocean Engineering Lab, a state-of-the-art wind wave facility for modeling scaled ocean events and technologies. Whereas Wind Blade Challenge engages students in developing an understanding of wind energy technology through blade design and construction, Wind Storm Challenge engages students in developing an understanding of wind energy through floating offshore wind platform design and manufacturing. Student teams design and build a scale-model floating wind turbine platform and deliver a sales pitch-style presentation to a panel of UMaine and industry judges. The teams' floating turbine models are tested under extreme winds and wave conditions and the team with the most stable platform and strongest presentation are selected as the winner. This year was the fifth year of Wind Storm Challenge.

These challenges target workforce development, technology development, and energy outreach. Maine is a state rich with wind energy and its economy stands to gain tremendously from its cultivation, yet many market impediments exist to realizing these gains. One problem is workforce: new technologies require new skilled labor for construction, operation, and continued development. This educational program is meant to accelerate and identify future engineers, regulators, and energy business professionals so that wind technology will continue to be developed and improved. Another hindrance is technology: both land-based and floating offshore wind technologies require further development to lower their levelized cost of energy. Finally, the Maine Composites Alliance, the Maine Ocean and Wind Industry Initiative, and the University of Maine have found that it is easier to have discussions regarding wind energy's pros and cons once common economic data have been agreed upon.

Winning team members of both competitions were offered internships with the UMaine Composites Center, contingent upon enrollment at the university, valued at more than $\$ 20,000$.

The proposed Cape Wind project in Massachusetts was dealt a most likely fatal blow when the two utilities with power purchase agreements pulled their agreements in 2015 after Cape Wind failed to obtain financing by the deadline. Without these power purchase agreements, the project cannot be built. Cape Wind brought the utilities' action to court. Most recently, a federal appellate court overturned a lower court's earlier ruling defending Cape Wind's power purchase agreement, representing another potentially lethal setback for the project. In addition, the project no longer has state permits or a valid permit from the Federal Aviation Administration.

Nevertheless, The Bureau of Ocean Energy Management (BOEM) granted the project a 2-year lease suspension, which expired on July 24, 2017. In March, BOEM released a Draft Supplemental Environmental Impact Statement for the Cape Wind project. 
Two federal lease sales in a second Massachusetts Wind Energy Area occurred in January 2015; the leases went to RES Americas and Offshore MW. Both leases were sold much cheaper than other lease areas, possibly due to the deeper water at the site. RES Americas paid \$281,285 for the lease, which covers 760 square kilometers and has the potential to generate more than 1 gigawatt of capacity. Danish developer and utility Ørsted (formerly known as DONG Energy) acquired RES Americas' lease. The Ørsted project is called Bay State Wind LLC. Ørsted's entry into the U.S. offshore wind sector indicates that major offshore wind developers are interested in the U.S. market. In December 2016, company officials announced that Eversource Energy, New England's largest energy delivery company, will jointly develop the project after acquiring a 50\% ownership interest in Bay State Wind (Dong Energy 2016). Offshore MW is developing its project in partnership with Vineyard Wind; it announced that Copenhagen Infrastructure Partners became a major investor in the project.

BOEM received two unsolicited lease requests for unleased areas within the Massachusetts wind energy area. Statoil Wind US LLC and PNE Wind USA, Inc. individually submitted unsolicited lease requests. BOEM determined that both parties are qualified to hold a lease and that there is competitive interest; BOEM will therefore proceed with its competitive leasing process for the area.

Massachusetts utilities jointly filed a draft proposal for the solicitation of long-term offshore wind contracts in May 2017. Electric utilities National Grid, Eversource Energy, and Unitil submitted a proposal to the Massachusetts Department of Public Utilities that included a timeline, method, and provisions for soliciting and executing long-term contracts for wind energy as required by Section 83 of "The Green Communities Act." Section 83D of the 2016 legislation An Act to Promote Energy Diversity ${ }^{143}$ requires the state's electric distribution companies to solicit bids for approximately 9,450,000 megawatt-hours of clean energy. It recognizes the environmental and economic benefits of offshore wind and directs the Department to weigh both types of benefits. Once the filing with the Department of Public Utilities is approved, the utilities will be able to seek bids for $400 \mathrm{MW}$ —and possibly up to $800 \mathrm{MW}$ - of offshore wind energy for January 2018 or later. The draft proposal included a project operation deadline of 2027. Once finalized, this proposal will be the first competitive solicitation for commercial-scale offshore wind in the United States.

Land-based wind backed by firm hydropower is an eligible resource under Section 83D solicitations. Bids were due July 27, 2017, and the evaluation team is expected to decide in early 2018 which bids will advance. Rhode Island and Connecticut may attempt to join in on this solicitation. Connecticut still has existing procurement authority available from previous legislative sessions, and Rhode Island utilities are permitted by current law to participate in such multi-state procurement efforts for renewable energy.

As mentioned earlier in this report, Massachusetts participated in the three-state initiative for clean energy procurement described in the Connecticut section. Eversource, a state utility, is obligated to procure a replacement contract to backfill the power purchase agreement with Cape Wind, and that procurement obligation will be added to the clean energy procurement initiative.

143 https://malegislature.gov/Bills/189/House/H4568 
As described in the Connecticut section above, the Connecticut Department of Energy and Environmental Protection selected 43.5 MW of land-based wind capacity under the 2- to 20-MW distributed generation RFP that was spread over multiple projects throughout the Northeast. The 5-MW Holiday Hill Community Wind project in Russell and the 12.5-MW Savoy Wind project in Savoy were among the projects selected to contract with the Connecticut utilities. Both projects are expected to come online during the first half of 2019.

Massachusetts has several wind energy education programs. The University of Massachusetts at Amherst has had an active wind energy program for more than 40 years. It is currently engaged in modeling offshore wind with energy storage. The University of Massachusetts at Lowell participated in DOE's 2014 and 2016 Collegiate Wind Competitions and 2015 Collegiate Wind Competition Technical Challenge. University of Massachusetts at Amherst also participated in the 2016 Competition and 2017 Collegiate Wind Competition Technical Challenge. Cape Cod Community College initiated a wind technician program focused on the offshore wind industry.

\subsubsection{New Hampshire}

New Hampshire had 185 MW of installed wind capacity at the end of December 2017 (American Wind Energy Association 2018), equivalent to approximately 2\% of in-state generation. As of 2016, total capital investment from wind energy was $\$ 374$ million. The industry supports between 100 and 500 direct and indirect jobs in the state (American Wind Energy Association 2017a). One wind farm, the 8.8-MW Antrim Wind project, is still in the development pipeline, having been selected to advance under the New England Clean Energy RFP (detailed in the Massachusetts and Connecticut sections), although it appears likely the project will drop out of the award group due to recently signed contracts for its expected output. The Antrim Wind project is expected to begin construction in late 2017, but a lawsuit filed in New Hampshire could delay construction and impact the project's developmental prospects.

In response to legislation passed in 2013, the New Hampshire Site Evaluation Committee developed siting guidelines, which were finalized and adopted in December 2015. The guidelines add more stringent provisions for addressing energy facilities’ sound, height, setbacks, cumulative impacts, and scenic quality. ${ }^{144}$ Even with state-level development guidelines, towns continue to pass restrictive wind siting bylaws and moratoria.

Projects in the state have faced high levels of opposition, leading to some wind development efforts being shelved. In 2014, Iberdrola announced that it would abandon its Wild Meadows Wind Farm plans, citing the company's recent experience with the Groton Wind Farm and the state's political and regulatory environments (Morris 2014). A second project, EDP Renewables 60-MW Spruce Ridge wind farm, withdrew from the independent system operator interconnection queue in early 2017. The proposed project area had included five towns that previously voted to restrict or reject new wind energy development.

The New Hampshire Legislature passed a bill in $2014^{145}$ creating an offshore wind study committee that presented its recommendations to the legislature and Governor in December of

\footnotetext{
${ }^{144} \mathrm{http}: / /$ www.windaction.org/posts/44712-new-hampshire-adopts-statewide-wind-siting-rules\#.V3VxWPkrJQI

145 https://legiscan.com/NH/text/HB1312/id/1039882
} 
that year. ${ }^{146}$ Included in the recommendations to the legislature was a multi-state approach to developing offshore wind and the designation of a BOEM multi-state task force to further explore the offshore wind potential in New Hampshire. One barrier for offshore wind in New Hampshire is its relative lack of a coastline; the state has just one small coastal region between Seabrook and Portsmouth. However, the state could participate in the offshore wind supply chain and would benefit from investments and opportunities in the Port of Portsmouth.

The Town of Durham passed a measure in June 2017 urging Governor Sununu to request the formation of a BOEM renewable energy task force that would explore commercial offshore wind development. Portsmouth and Dover are also considering resolutions in support of offshore wind.

\subsubsection{New Jersey}

Onshore and offshore developments have moved slowly in New Jersey, which as of December 2017 is stalled at 9 MW of land-based installed wind energy (American Wind Energy Association 2018). Total in-state generation by wind turbines is less than 1\%. New Jersey has established an offshore wind requirement of 1,100 MW by 2021. As of 2016, total capital investment in New Jersey is about \$15 million, and the industry supports between 100 and 500 direct and indirect jobs (American Wind Energy Association 2017a). Fishermen's Energy, a proposed five-turbine offshore project that DOE previously supported as one of its Offshore Wind Advanced Technology Demonstration Projects, did not receive approval from the New Jersey Board of Public Utilities to move forward. In a recent appellate court decision, the court backed the board's rejection of the demonstration project, affirming that Fishermen's Energy had not established the project's financial viability. Fishermen's Energy has pursued approval to move forward with the project since 2008. Another offshore wind project, a proposed 500-MW development, includes a lease secured by U.S. Wind Inc. RES America Developments Inc. acquired a commercial lease for southern lease area OCS-A-0499 in February 2016; RES America transferred its lease to DONG energy. The proposed project capacity is 1,000 MW.

The Atlantic Wind Connection was a proposed offshore transmission project linking northern New Jersey to southern Virginia, with points in between. The entire project could support the development of 6,000 MW of offshore wind power. Tax revenue from the project was estimated at about \$18 million annually. The first phase of the project is the New Jersey Energy Link, linking south Jersey with north Jersey. However, the Atlantic Wind Connection is currently on hold. The New Jersey link, while still an undersea transmission system, does not mention connection to offshore wind farms in its proposal.

There are two operating land-based wind projects in New Jersey. The Bayonne Municipal Utilities Authority has one 1.5-MW turbine that came online in 2012. The 7.5-MW JerseyAtlantic Wind Farm came online in 2005.

\subsubsection{New York}

With 1,829 MW of installed wind as of December 2017 (American Wind Energy Association 2018), New York leads the Northeast in overall wind energy capacity. This amount of development equates to a $\$ 3.7$ billion capital investment for the state as of 2016, and the industry

${ }^{146}$ http://saplnh.org/wp-content/uploads/2016/10/NH_Leg_Offshore-wind_report_HB1312-2014.pdf 
supports between 1,000 and 2,000 direct and indirect jobs. Wind energy provides New York with $3 \%$ of its total in-state energy production (American Wind Energy Association 2017a).

The small and distributed wind markets continue to be active in New York. While the main driver of this has historically been an incentive program provided through the New York State Energy Research and Development Authority (NYSERDA), third-party leasing is a new model that is expected to further advance this type of installation. United Wind, a leader in this area, reports that it plans to install 100 Bergey WindPower Excel 10 wind turbines in central and western New York as part of its WindLease program.

Currently the state is implementing Reforming the Energy Vision, ${ }^{147}$ a re-design of its overall energy strategy. The Public Service Commission issued an order in 2016 to adopt the Clean Energy Standard, which contains an aggressive goal of obtaining 50\% of New York's electricity from renewable sources by 2030. The Clean Energy Standard is one component of the state's broader Reforming the Energy Vision initiative.

The Clean Energy Standard includes the Renewable Energy Standard, which acts as a successor to the RPS program that expired in 2015. The Renewable Energy Standard is further divided into tiers. Tier 1 is designed to incent new renewable energy development, including new land-based wind facilities. Tier 2 is designed as a maintenance tier for generators that came online prior to 2003 and is meant to help older plants that are experiencing financial distress remain open. In June 2017, NYSERDA issued a solicitation for Tier 1 Renewable Energy Credits under the Renewable Energy Standard. NYSERDA expects this RFP to result in between 40 and 60 new renewable energy projects, some of which are likely to be new wind projects.

On January 10, 2017 new legislation was introduced ${ }^{148}$ that would institute a 40-mile buffer zone between military airfields and airbases in the state. While the bill did not become law during the 2017 legislative session, it’s expected to be reintroduced next session.

Governor Cuomo made a major offshore wind announcement as part of his state of the state address in January 2017, in which he proposed developing 2,400 MW by 2030. NYSERDA is leading the charge to develop an Offshore Wind Master Plan, a comprehensive strategy for efficiently and cost-effectively developing offshore wind for New York State. Along with other state agencies and a broad group of stakeholders, NYSERDA will work to identify:

- Leasing sites and leasing strategies

- Cost, benefit, and interconnection studies

- Recommendations for energy offtake agreements

- Local economic impacts and job creation

- Stakeholder and community engagement

- Viewshed, fishing, and other mitigation efforts.

${ }^{147}$ https://rev.ny.gov/

148 https://www.nysenate.gov/legislation/bills/2017/s1755/amendment/a 
In September 2016, NYSERDA released Blueprint for the New York State Offshore Wind Master Plan, which outlines NYSERDA's next steps to develop the master plan and the importance of contributions from stakeholder groups to the master plan. ${ }^{149}$

Also in January 2017, Governor Cuomo encouraged the Long Island Power Authority to approve Deepwater Wind's 90-MW South Fork project. Later that month, Long Island Power Authority approved the project, agreeing to purchase all electricity generated by the project for 20 years. Long Island Power Authority had tried to procure 280 MW of offshore wind power in 2013. In 2015, another RFP was released calling for an additional 210 MW of renewable power, for which offshore wind was an eligible technology.

NYSERDA has invested nearly \$10 million a year from 2012-2016 in efforts to reduce barriers and increase acceptance of clean power generation in New York through its Technology and Market Development Program Initiatives.

New York is also reviewing the planning process for its transmission system, which currently is constrained and is affecting wind development and operation. In December 2015, the New York State Public Service Commission determined that there is a "transmission need driven by Public Policy Requirements for new 345-kV major electric transmission facilities" to "provide additional transmission capacity to move power from upstate to downstate.”

Current land-based wind projects include the 449-MW Bull Run Wind Energy Center developed by Invenergy (estimated commercial operation date of 2019); the proposed 126-MW Cassadaga Wind Project by Everpower (filed for Article 10 Siting in May 2016 and selected by Massachusetts, Connecticut, and Rhode Island under the Clean Energy RFP); the 300-MW Baron Winds Wind Project by Everpower (yet to file for Article 10); and the 100-MW proposed Ball Hill Wind Energy Project by RES. Other projects that have filed for state permits under Article 10 include the proposed 100-MW North Ridge Wind Farm by Atlantic Wind, LLC; the proposed 103-MW Eight Point Wind Energy Center by NextEra Energy; the proposed 103-MW Galloo Island Wind project; the proposed 201-MW Lighthouse Wind facility by Apex Clean Energy; the proposed 350-MW Mad River Wind Farm by Atlantic Wind, LLC; and the proposed 126-MW Number Three Wind Farm by Invenergy.

${ }^{149}$ https://www.nyserda.ny.gov/-/media/Files/Publications/Research/Biomass-Solar-Wind/New-York-State-

Offshore-Wind-Blueprint.pdf 


\section{Statoil Wins Historic New York Offshore Wind Lease Auction}

In mid-December 2016, after a day and a half of auction proceedings, the Bureau of Ocean Energy Management declared Statoil Wind US LLC as the provisional winner of its New York Wind Energy Area lease sale. Statoil, a Norwegian energy company with global operations, is an experienced developer of offshore wind projects in Europe. The company brings its oil and gas sector expertise to developing offshore wind projects in challenging environments. It is one of the few companies working to commercialize floating offshore wind foundations and, most recently, announced that it would pilot a battery storage solution for offshore wind energy.

The lease announcement is a clear indication of growing market interest in offshore wind energy. Six bidders (including NYSERDA) participated through more than 20 rounds of bids up to $\$ 14.5$ million. In the end, after 31 rounds of bids and two remaining bidders, the final bid was placed at $\$ 42,469,725$. This is the highest price a federal offshore wind lease sale has obtained. The lease area contains 79,000 acres and has five full outer continental shelf blocks; it has a projected capacity of $800 \mathrm{MW}$. It is located 14 to 30 miles off the shores of Jones Beach, New York.

Fourteen developers were qualified to participate in the auction, including Deepwater Wind, DONG Energy, EDF Renewable Development, and NYSERDA. NYSERDA had announced its intention to participate in the BOEM auction in June 2016 to ensure that offshore wind reduces costs for retail consumers.

Offshore wind is a critical component of New York's $50 \%$ by 2030 Clean Energy Standard. If NYSERDA had won the auction, NYSERDA representatives would have undertaken pre-development work such as environmental studies and site assessments and then packaged the work with an off-take agreement before selecting a project developer through a competitive process. These plans had the potential to de-risk project development and reduce costs. Such is the arrangement in Europe, which hosts a robust 11-plus-gigawatt offshore wind market; in Europe, state governments pay for crucial project development activities and, in some countries, even pay for the cost of transmission connection. Government involvement can streamline pre-development work and de-risk projects by providing an accurate assessment of the wind resource and sea floor substrate, thereby reducing costs. A Clean Energy Group-sponsored report found that predevelopment activities generally cost between $\$ 30$ million and $\$ 50$ million; the report suggested that these risks and associated costs be addressed before awarding sites to developers.

Prior to the auction, various developers had expressed general support for NYSERDA's proposal. With the provisional lease in Statoil's hands and no procurement mechanism in place, it is unclear what the next steps will be. Statoil has said it will work closely with NYSERDA on resource studies and site assessments, as well as on power offtake options.

\subsubsection{Pennsylvania}

As of December 2017, Pennsylvania had 1,369 MW of installed wind capacity (American Wind Energy Association 2018). In 2016, wind development in the state equated to a $\$ 2.8$ billion capital investment and supported between 1,000 and 2,000 direct and indirect jobs. Total in-state power generation from wind energy is about 2\% (American Wind Energy Association 2017a). In 2004, Pennsylvania established its Alternative Energy Portfolio Standards Act, which requires $18 \%$ of the state's energy to be generated by clean, efficient sources by 2021 (Pennsylvania Public Utility Commission 2016). NJR Clean Energy Ventures completed the 40-MW Ringer Hill wind farm in late 2016. All utility-scale wind farms are located in the northeastern or southwest central areas of the state. The largest wind farm in Pennsylvania is the 141-MW Mehoopany wind farm (Saint Francis University 2017). 
Wildlife issues, including wind energy's impact on bats in the state, pose challenges for responsible wind development, as have concerns related to sound, health, and property values. Another significant issue for the state is that many of the windiest, undeveloped locations are on the nearly 1.5 million acres of state game lands, which are not available for wind project development (S. Stewart, personal interview, December 2015).

Pennsylvania is also participating in the Wind for Schools project through the engagement of Pennsylvania State University and the installation of four wind systems at schools. Pennsylvania State University placed first in DOE’s 2014 and 2016 Collegiate Wind Competitions and participated in the 2015 and 2017 Collegiate Wind Competition Technical Challenges. The university was also selected to participate in Collegiate Wind Competition 2018.

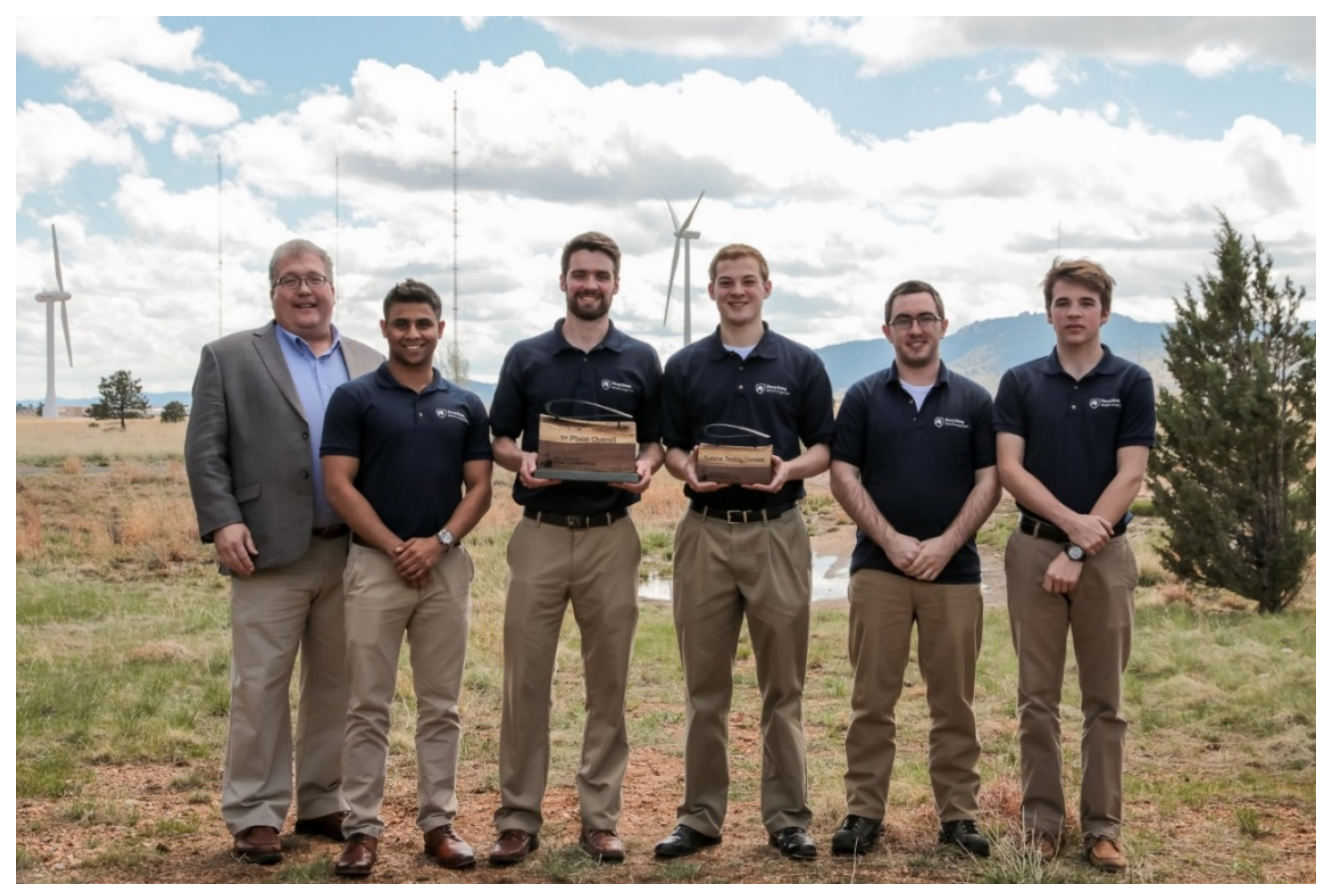

Figure 14. The Pennsylvania State University team took first place overall and the tunnel testing award at the Collegiate Wind Competition 2017. Photo by Lee Jay Fingersh, NREL

\subsubsection{Rhode Island}

Rhode Island has 54 MW of wind energy installed as of December 2017 (American Wind Energy Association 2018). As of 2016, total capital investment is about \$344 million with fewer than 100 direct and indirect jobs supported (American Wind Energy Association 2017a). As discussed earlier in this section, the 30-MW Block Island offshore wind farm came online in November 2016. The \$225 million project provides electricity to Block Island and Rhode Island customers.

In-state opposition to wind development exists, particularly in rural areas of Rhode Island. Recently in the town of North Smithfield, the local planning board placed a moratorium on new wind development until proper siting guidelines were established. Many of the town's residents opposed the construction of a 2.5-MW turbine in the town. 
Rhode Island legislators passed a variety of wind related bills during the 2017 legislative session that will impact deployment moving forward. House Bill $5274^{150}$ and Senate Bill $112^{151}$ extend the state's RE Growth program for 10 years. The program mandates that National Grid dedicates $40 \mathrm{MW}$ of power production from new wind and solar projects on an annual basis. H5483 ${ }^{152}$ and Senate Bill $637^{153}$ address disputes related to which party is responsible for paying interconnection costs while establishing deadlines for interconnection work and related applications. House Bill $6095^{154}$ and Senate Bill $570^{155}$ allow landowners to use $20 \%$ of farmland in the farm, forest, or open space program for renewable energy projects while maintaining current property-tax status.

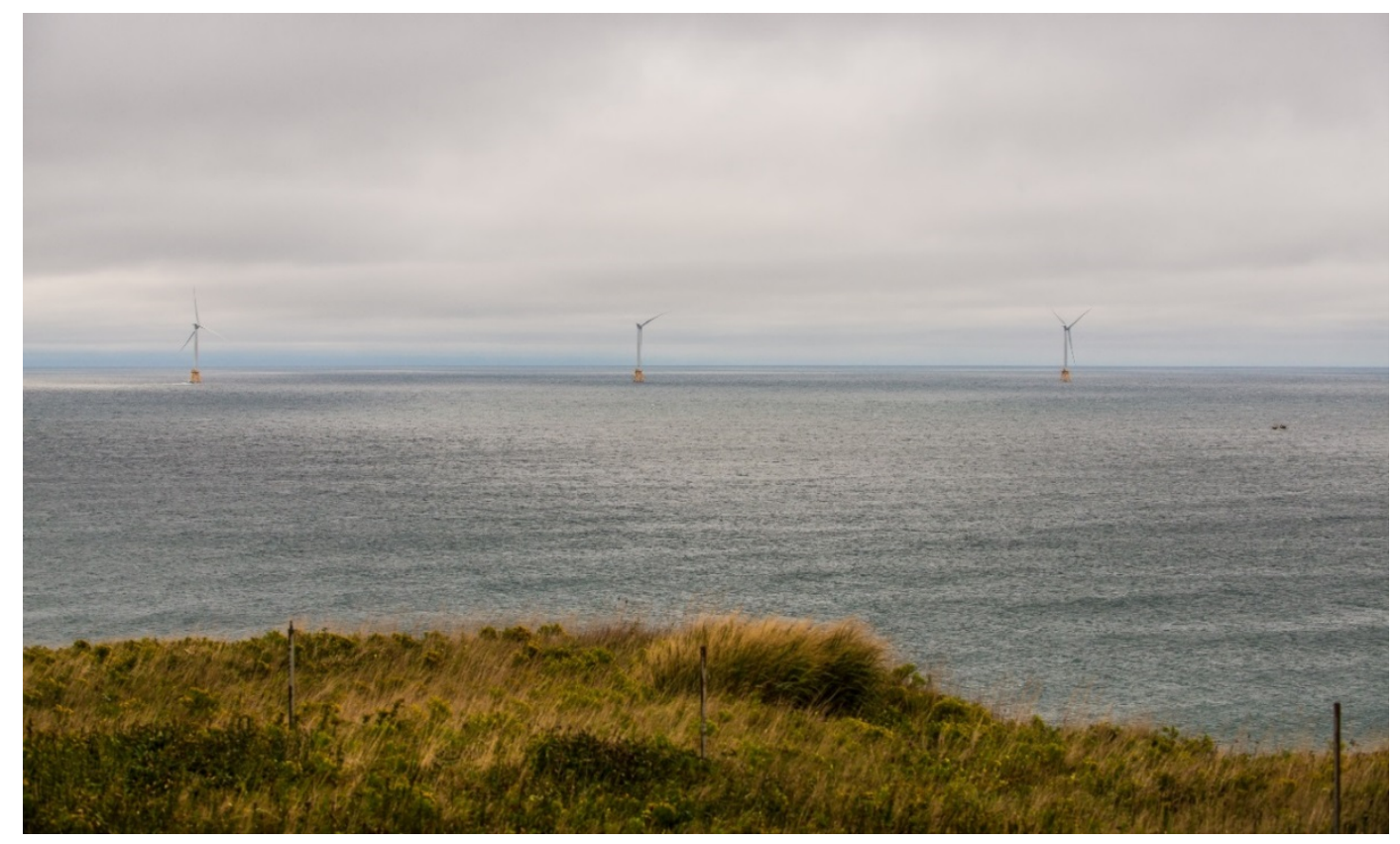

Figure 15. The Block Island Wind Farm (as seen from Block Island, Rhode Island) is the first U.S. offshore wind farm. Photo by Dennis Schroeder, NREL 40396

During the first quarter of 2017, the Rhode Island Office of Energy Resources proposed a set of land-based siting guidelines to assist local municipalities in developing local wind siting ordinances to streamline the development process. The guidelines are currently in draft form ${ }^{156}$ and are meant for turbines with a nameplate capacity higher than $100 \mathrm{~kW}$.

Rhode Island is part of the three-state initiative for clean energy procurement described in the Connecticut section.

\footnotetext{
${ }^{150} \mathrm{https} / / /$ legiscan.com/RI/bill/H5274/2017

151 https://openstates.org/ri/bills/2017/SB112/

152 http://webserver.rilin.state.ri.us/BillText/BillText17/HouseText17/H5483B.pdf

153 https://openstates.org/ri/bills/2017/SB637/

154 https://legiscan.com/RI/bill/H6095/2017

$155 \mathrm{https://openstates.org/ri/bills/2017/SB570/}$

156 http://www.energy.ri.gov/documents/landwind/WindSitingGuidelines_1-31-2017_FINAL.pdf
} 


\subsubsection{Vermont}

Vermont's total wind energy capacity was 149 MW at the end of December 2017 (American Wind Energy Association 2018). In 2016, wind power provided approximately 15\% of in-state electricity generation. As of 2016, capital investments total \$253 million, and the wind industry supports between 100 and 500 direct and indirect jobs (American Wind Energy Association 2017a). Concerns about turbine aesthetics, health impacts, wildlife (Ring 2015), and property value impacts (Preedom 2015) arise frequently in the state, slowing development and leading to community resistance to hosting wind turbines.

The Vermont legislature passed an aggressive RPS (called the Renewable Energy Standard) starting at 55\% by 2017 and then increasing by $4 \%$ every 3 years until reaching $75 \%$ by 2032 (DSIRE 2016). Specifics are provided for distributed generation, retail electricity providers, and municipal utilities. Although the targets for the program are high, the emphasis on distributed generation, efficiency, and the ability for existing renewable generators to participate and compete with new renewable generators mean there's little incentive for utility-scale wind to participate.

The Energy Development Improvement Act is legislation enacted in 2016 with several wind siting provisions that provide an increased voice for citizens and regional planning commissions during the siting process and addresses wind impacts such as noise, lighting, and visual impacts. The Vermont Public Utilities Commission recently accepted citizen and stakeholder input in their development of a permanent noise rule, pursuant to the Energy Development Improvement Act. Local resistance to wind generation of any scale is further dampening new development. Projects such as Swanton (17.5 MW) and Kidder Hill Community Wind (5 MW) are facing strong local opposition. Both Swanton and Kidder Hill were selected by the Connecticut Department of Energy and Environmental Protection under the 2- to 20-MW distributed generation RFP (see the Connecticut section for more information). Construction on the 30-MW Deerfield wind project was complete in the fourth quarter of 2017. 


\section{Northwest Region}

Colleagues from the Northwest Wind Resource and Action Center (NW Wind Center) and the National Renewable Energy Laboratory (NREL) collaborated to provide the following assessment of the state of the wind industry in this region.

The NW Wind Center ${ }^{157}$ encompasses Idaho, western Montana, Oregon, Washington, and Wyoming (see Figure 4). Renewable Northwest Project is the principal investigator. Northwest Sustainable Energy for Economic Development (Northwest SEED, now Spark Northwest) ${ }^{158}$ facilitates committee activities related to distributed and community wind. The Oregon Department of Energy leads the offshore wind efforts while the Commerce Departments of Washington and Montana, along with Boise State University, serve on the steering committee.

\subsection{Overview of Regional Wind Market}

All states in the region face barriers related to environmental regulations and project siting; depressed electric market prices; low natural gas costs; little load growth; and a combination of transmission constraints, a need for balancing area coordination, and better integration services markets. In addition, those states with renewable portfolio standards (RPSs) (Montana, Oregon, and Washington) see decreased market potential as utilities fulfill their near-term target requirements, and states are seeing attempts to limit total project capacity and contract length for standard Public Utility Regulatory Policies Act (PURPA) contracts. These factors have slowed the pace for new project development, although a pipeline of approved projects exists once markets improve.

Recent events that could improve the market for wind energy in the region include:

- Oregon’s Clean Electricity and Coal Transition law (SB 1547-B) increases the RPS targets for large investor-owned utilities to $50 \%$ by 2040 and eliminates the use of coal power by utilities in the state no later than 2035.

- The Boardman (Oregon) and Centralia (Washington) coal plants are scheduled to be closed.

- Several Northwest utilities have, or are working toward, joining the California Independent System Operator (CAISO) energy imbalance market (EIM) or other coordinating efforts.

- Utility integrated resource plans in the region include 2 gigawatts of proposed renewable.

- Large commercial customers are demanding renewables from their utilities, acquiring their own renewable projects, or working on direct access options.

The following section provides an overview of the wind industry in the region. Stakeholders can consult the U.S. Department of Energy's (DOE’s) interactive Wind Vision Study Scenario Viewer $^{159}$ to learn more about state-specific costs, benefits, and other impacts from wind energy development related to the Wind Vision scenarios.

\footnotetext{
157 http://nwwindcenter.org/

158 As of June 2017, Northwest SEED changed its name to Spark Northwest.

159 http://en.openei.org/apps/wv_viewer/
} 
Table 20. Key Statistics for States in the Northwest Wind Resource and Action Center Region

\begin{tabular}{|c|c|c|c|c|c|}
\hline & ID & $\mathbf{M T}^{160}$ & OR & WA & WY \\
\hline Installed Wind (MW), End of 4Q17 161 & 973 & 695 & 3,213 & 3,075 & 1,489 \\
\hline $\begin{array}{l}\text { Percentage of In-State Energy } \\
\text { Production, as of December } 2016^{162}\end{array}$ & $15 \%$ & $8 \%$ & $12 \%$ & $7 \%$ & $9 \%$ \\
\hline $\begin{array}{l}2017 \text { Wind Power Capacity Additions } \\
(\mathrm{MW})^{163}\end{array}$ & 0 & 0 & 50 & 0 & 0 \\
\hline $\begin{array}{l}\text { Wind Capacity under Construction } \\
\text { (MW), End of } 4 \mathrm{Q} 17^{164}\end{array}$ & 0 & 105 & 202 & 120 & 3,000 \\
\hline $\begin{array}{l}\text { Projected Potential Capacity (MW), } \\
80 \text { m, 30\% Capacity Factor }\end{array}$ & 18,076 & 944,004 & 27,100 & 18,479 & 552,073 \\
\hline $\begin{array}{l}\text { Projected Potential Capacity (MW), } \\
100 \text { m, 30\% Capacity Factor }\end{array}$ & 44,770 & $1,012,355$ & 50,566 & 32,606 & 593,769 \\
\hline $\begin{array}{l}\text { Distributed Wind Capacity, as of } \\
\text { December } 2016(\mathrm{MW})^{165}\end{array}$ & 0.02 & 3.6 & 3.6 & 10.6 & 3.8 \\
\hline $\begin{array}{l}\text { Proposed Offshore Wind Projects } \\
\text { (MW), as of December } 2016^{166}\end{array}$ & $\mathrm{n} / \mathrm{a}$ & $\mathrm{n} / \mathrm{a}$ & 0 & 0 & $\mathrm{n} / \mathrm{a}$ \\
\hline
\end{tabular}

Sources: American Wind Energy Association, U.S. DOE

\subsubsection{Renewable Portfolio Standards}

In the NW Wind Center's region, Oregon, Washington, and Montana each have an RPS in place. In 2005, Montana passed an RPS requiring large investor-owned utilities to acquire $15 \%$ of their energy from new renewable resources by 2015. In 2014, the Energy and Telecommunications Interim Committee reviewed the RPS and recommended the standard remain static at $15 \%$ for 2015 and beyond. Montana utilities met the 2015 target but will need to add renewable resources in the future to maintain compliance as current contracts expire. Montana also has a Community Renewable Energy Project provision in the state's RPS that requires utilities to procure a certain amount of nameplate capacity of smaller (less than $25 \mathrm{MW}$ ), locally owned renewable energy projects, either wholly utility-owned or at least $50 \%$ owned by Montana investors. NorthWestern Energy is the only utility with a Community Renewable Energy Project obligation left in Montana and must procure roughly $45 \mathrm{MW}$. Satisfying the requirement resulted in regulatory and project development challenges in recent years but remains a potential near-term driver for renewable energy projects in the state.

\footnotetext{
${ }^{160}$ Montana is divided between two RRCs: Northwest Wind Resource and Action Center (western Montana) and Midwest Wind Energy Center (eastern Montana). For reporting purposes, a Montana summary is provided in this section.

161 American Wind Energy Association 2018

162 American Wind Energy Association 2017a

163 American Wind Energy Association 2018

164 American Wind Energy Association 2018

165 Distributed wind project capacity is defined as cumulative capacity, 2003-2016 (U.S. DOE 2017a).

166 American Wind Energy Association 2017b
} 
The Oregon Renewable Energy Act (Senate Bill $838^{167}$ ) was signed into law in 2007. The Act establishes a Renewable Energy Standard that requires Oregon's largest utilities to acquire 25\% of their electricity from renewable sources by 2025. The passage in 2016 of the Clean Electricity and Coal Transition law (SB 1547-B ${ }^{168}$ ) added a 2040 target of 50\% for large investor-owned utilities to the RPS while also eliminating coal power from all utility portfolios by 2035. Smaller Oregon utilities must meet targets of $5 \%$ or $10 \%$ by 2025. Oregon utilities have met the 2015 targets but will need to acquire new resources to meet the targets for 2025 and beyond.

In November 2006, Washington voters passed Initiative 937 (I-937 ${ }^{169}$ ), the Clean Energy Initiative. I-937 enacts a renewable energy standard that requires Washington's 17 largest utilities to get 15\% of their electricity from homegrown renewable energy sources by 2020 . Utilities are also required to pursue cost-effective energy efficiency and conservation measures. Washington utilities met their interim targets of 3\% by 2012 and $9 \%$ by 2016, but many must acquire additional resources to meet the 2020 target. In the wake of Oregon's Clean Electricity and Coal Transition law, advocates are exploring options to expand Washington's RPS.

Table 21. RPS Overview for States Served by the Northwest Wind Resource and Action Center

\begin{tabular}{|c|c|}
\hline & RPS \\
\hline Idaho & None \\
\hline Montana & $15 \%$ by 2015 ; met and remains in effect \\
\hline & $\begin{array}{l}\text { Large investor-owned utilities: } 50 \% \text { by } 2040 \\
\text { Large consumer-owned utilities: } 25 \% \text { by } 2025 \\
\text { Small utilities: } 10 \% \text { by } 2025\end{array}$ \\
\hline Oregon & Smallest utilities: $5 \%$ by 2025 \\
\hline Washington & $15 \%$ renewables by 2020 \\
\hline Wyoming & None \\
\hline
\end{tabular}

\subsubsection{Communities with $100 \%$ Renewable Energy Commitments}

Many state public utility commissions are working with utilities to choose the direction of their energy portfolios. While some states have mandated and voluntary renewable energy goals or standards, some cities have taken an additional step to create their own commitments to clean energy, some of which exceed levels established by their states. Two communities in the Northwest Region have made $100 \%$ renewable energy commitments (Table 22).

\footnotetext{
$167 \mathrm{http}: / /$ www.oregon.gov/dsl/WW/Documents/SenateBill838.pdf

168 https://olis.leg.state.or.us/liz/2016R1/Downloads/MeasureDocument/SB1547/Enrolled

169 https://www.sos.wa.gov/elections/initiatives/text/i937.pdf
} 
Table 22. Communities Served by the Northwest Regional Resource Center with $100 \%$ Renewable Energy Commitments

\begin{tabular}{lll}
\hline City & State & Target Year \\
\hline Edmonds & WA & End of 2030 \\
Portland & OR & 2035 \\
\hline
\end{tabular}

Source: Sierra Club

\subsection{Regional Transmission}

As noted earlier, transmission constraints are challenging for wind development in the region. In a development that will affect a number of states in the West, much activity has occurred around PacifiCorp's interest in joining CAISO and evolving it into a regional multi-state system operator. Expanding this market would help to address wind integration issues and would use existing transmission lines much more effectively for bringing new wind energy to market.

The CAISO EIM is already delivering benefits and attracting potential new participants. NorthWestern Energy is the latest investor-owned utility to announce that it is studying the benefits of joining the EIM. Seattle City Light signed the implementation agreement to join the EIM, becoming the first publicly owned utility to join. In Idaho, Idaho Power committed to join the CAISO EIM, and approval from the Idaho Public Utilities Commission is anticipated. Powerex also announced that it will join the EIM in 2019, at which time it will become the first international participant. Stakeholders are also working with the Bonneville Power Administration (BPA) to accommodate those joining the EIM and to upgrade BPA's own systems to ultimately accommodate a regional system operator. Since most signs are that CAISO regionalization is on a slower track, emphasis has been on getting more utilities to join the EIM, see the benefits, and strongly consider regionalization.

Stakeholders in the Northwest and California have also been working with Northwest hydropower generators to get the CAISO market to use more clean hydropower for flexible capacity needs instead of natural gas plants that are ultimately less flexible, contribute to wind and solar curtailments, and emit carbon dioxide. Building up these bilateral market transactions is an important step to improved regional coordination and a coordinated market that efficiently integrates deep penetrations of new renewables, and education efforts have been made with Public Utility Commissions in Washington and Oregon about this important opportunity.

Also, the Boardman-to-Hemmingway 500-kilovolt transmission line scored well in Idaho Power's integrated resource plan, and work is nearly finished with the federal (Bureau of Land Management) and state (Idaho and Oregon) siting processes. This line will provide important connectivity between Wyoming and Idaho wind and the markets in Oregon and Washington.

Longstanding efforts to increase transmission access and efficiency on BPA's transmission system in the I-5 corridor culminated in May 2017 when BPA announced that it would not build the costly "I-5" transmission line and instead would invest in non-wires solutions, redispatch of generators, and a modernized business model for their transmission business line. The beginning of a 2-year implementation effort is now underway. If all improvements identified by BPA are implemented, there will be significant amounts of new transmission access in the Northwest at 
less cost to renewable energy generators, less need for natural gas plants in the region, and significant opportunities for storage and demand response.

Efforts to provide access for Montana's wind potential to west coast load centers also saw some gains over the past year. At an April stakeholder meeting in Portland, Northern Tier Transmission Group (NTTG) accepted a study request from Renewable Northwest and NW Energy Coalition to analyze "dynamic stability" and voltage concerns and solutions associated with retiring Colstrip Units 1, 2, and 3, and replacing it with equal amounts of wind generation. The draft NTTG study found that, under certain assumptions, the system performed equally well during reliability events with wind replacing the three Colstrip units.

A favorable settlement was reached on BPA's wind and solar integration rates. The settlement results in much lower integration charges than BPA proposed in the rate case, and many of the integration charges will be at their lowest point since 2009. BPA also will establish a 15-minute scheduling incentive for solar energy and commit to significant solar integration analysis and cost mitigation discussions prior to the next rate case. All risk of mid-rate period increases for these rates has also been removed per the settlement. BPA did not, however, decide in this rate case to eliminate the additional Montana Intertie charge that has stymied wind energy exports out of the state despite the significant political support to do so. Resolutions from the Montana and Washington legislatures were passed; the Montana Public Service Commission; Senators Cantwell, Tester, and Merkely; and Governor Bullock sent letters to BPA calling for elimination of this rate. In their final record of decision, BPA officials reduced the rate by $15 \%$ and committed to engaging in public workshops to address transmission barriers for Montana wind.

\subsection{Workforce Development}

Several long-standing educational programs exist within the region: Boise State University, University of Washington, and Montana State University. Colombia Gorge Community College hosts one of the oldest wind technician training programs. Educational activities are described in more detail in the state sections below. The WINDExchange website also offers information and interactive maps regarding workforce development, DOE's Collegiate Wind Competition, DOE's Wind for Schools project, school wind project locations, and locations of education and training programs in the NW Wind Center's region and other states. 


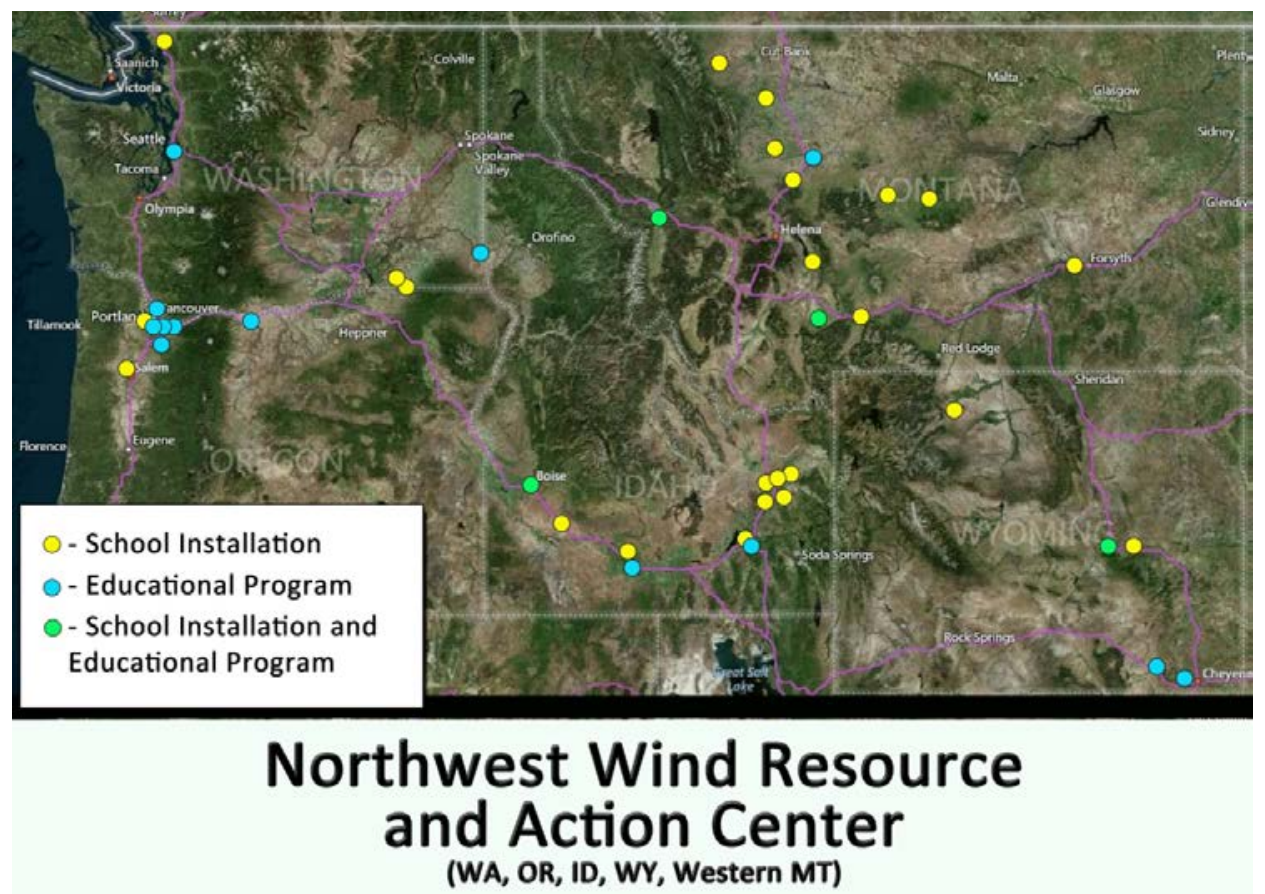

Figure 16. Map of school wind turbine projects, educational programs, and locations with both wind turbines and educational programs within the Northwest Wind Resource and Action Center's area

\subsection{Manufacturing and Economic Development}

NREL researchers compiled the following wind energy manufacturing data for this region as part of DOE’s annual wind market report effort (U.S. Department of Energy 2017c).

Table 23. Wind-Related Manufacturing Overview for States Served by the Northwest Wind Resource and Action Center

\begin{tabular}{llll}
\hline Name & City & State & Component \\
\hline Moventas & Portland & OR & Gearboxes \\
Pacific Crest & White City & OR & Electrical \\
XZERES Wind & Wilsonville & OR & Distributed wind turbines \\
\hline Power Climber & Seattle & WA & Tower internals \\
\hline
\end{tabular}

Additional economic impacts from wind development include the capital investment, jobs supported, tax revenues paid, payments in lieu of taxes, and land lease payments made by wind developers during construction and the ongoing maintenance of wind plants. The American Wind Energy Association performs modeling work that identifies the impacts of all wind-related investment. Table 24 summarizes the total jobs (including construction jobs in 2015) and capital investment over time in wind farms in the NW Wind Center states. Examples of economic impacts are provided in each of the state overviews below. 
Table 24. Economic Impacts of Wind Development in States Served by the Northwest Resource and Action Center

\begin{tabular}{lll}
\hline State & Direct and Indirect Jobs Supported & Total Capital Investment \\
\hline Idaho & $501-1,000$ & $\$ 2.1$ billion \\
\hline Montana & $501-1,000$ & $\$ 1.4$ billion \\
\hline Oregon & $2,001-3,000$ & $\$ 6.5$ billion \\
Washington & $1,001-2,000$ & $\$ 6.1$ billion \\
\hline Wyoming & $501-1,000$ & $\$ 3.1$ billion \\
\hline
\end{tabular}

Source: American Wind Energy Association 2017a, as of 2016

\subsection{Key Stakeholder Groups and Development Challenges}

The NW Wind Center targets these stakeholder groups:

- Bonneville Power Administration

- County commissioners

- Developers

- Educational institutions (academia)

- Experts (researchers, technical)

- Federal agencies and government organizations (decision makers, elected officials, policymakers)

- Public interest groups (advisory, advocacy, affiliates, boards, committees, community, consumer, councils, non-governmental organizations, partner network, working group)

- Industry (manufacturers, supply chain, associated businesses) and industry trade groups

- Media

- Merchant energy suppliers

- Non-elected government officials

- Public (engaged citizens, interested and general public)

- Regulatory (public utility commissioners, decision makers, staff, interveners)

- State agencies and government organizations (decision makers, elected officials, governor staff, policymakers)

- Tribal governments and community members

- Utilities (power authorities, publics, municipals, co-ops, decision makers, staff) and utility trade groups.

The information provided to these stakeholder groups addresses the following wind energy development market barriers that are prevalent in this region. Each barrier is followed by a more detailed description specific to the Northwest region and an example of the NW Wind Center's work to address the barrier with their stakeholders. These include:

Varying wind technology costs and outputs. Wind capacity factors vary across the West, and wind competes with low-cost natural gas and utility-scale solar photovoltaic power plants. Nevertheless, wind is increasingly competitive at the utility scale and continues to increase in value as a resource as technology advances and costs decline. 
The NW Wind Center delivers information about technological advances (through phone calls, webinars, and fact sheets) to decision makers in the region and works to insert up-to-date cost information in regulatory proceedings. This is particularly important in the regulatory sphere, with a need to address the state-of-the-art in resource planning processes and ensure accurate wind information is utilized in utility integrated resource planning.

Transmission constraints and outdated market operations. Through engagement of BPA, utilities, and other key stakeholders, the NW Wind Center provides information and guidance to meet the need for transmission and energy market advances. These include a liquid bilateral market for integration resources, 15-minute scheduling, and development of a regional EIM and/or participation in existing energy imbalance markets in adjoining regions.

Uncertain permitting processes resulting from the presence of wildlife species. Across the West, wind developers are engaged with the ongoing concerns related to protection of wildlife and habitats, especially sage grouse and golden eagles. The NW Wind Center is working to meet the need for science-based resource planning in siting guidelines, especially for development in sage grouse areas.

Lack of zoning and permitting best practices for distributed/community wind. The general public and local decision-makers often cite a lack of scientifically credible information on zoning and permitting practices as an issue. In some cases, this information is available but not readily accessible; in others, the information is not conclusive. Where information does exist, it should be made readily available in a form that is understandable for identified stakeholders. In addition, technical assistance for potential community wind projects is lacking.

The NW Wind Center developed state-specific wind energy permitting toolkits ${ }^{170}$ and conducted outreach to offer technical assistance for counties interested in exploring community wind projects.

Restricted access to capital and financial incentives for distributed and community wind development. The NW Wind Center assists stakeholders in understanding these issues and identifying available incentives and resources.

Lack of strong technical information baseline for offshore wind. The Northwest coast provides many challenges for offshore wind development, including deep water, limited transmission infrastructure, and the lack of a large load center on the coastline. While floatingplatform technology is relatively new, it has been demonstrated successfully in Europe. In the Northwest, many stakeholders are not aware of the resource opportunity. This includes the value of stronger, more consistent winds offshore and the value of geographic diversity of renewable energy resources for the region; both of these may contribute to easing integration of offshore wind into the utility's system. The Northwest RRC is working to make current information on the state of the offshore sector publicly available to help inform efforts to support an initial demonstration project in the region.

${ }^{170}$ http://www.nwwindcenter.org/content/permitting-zoning-resources 


\subsection{Collaborating Organizations}

RRCs engage diverse stakeholder groups, disseminate targeted technical information about appropriate wind deployment, and provide forums for constructive dialogue. In addition to credible partners such as universities and state energy offices, RRC leaders identify and engage with strong state champions and include these champions in activities whenever possible. Organizations that have collaborated with the Northwest Wind Center include American Wind Energy Association; Avangrid Renewables; Boise State University; Center for Energy Efficiency \& Renewable Technology; Climate Solutions; Columbia Gorge Community College; Community Renewable Energy Association; Distributed Wind Energy Association; DNV GL; EDF Renewable Energy; EDP Renewables North America; eFormative Options; Endurance Wind Power; Everpower; EWT Americas; Idaho Conservation League; Idaho National Laboratory; Invenergy; Montana Department of Environmental Quality; Montana Environmental Information Center; Montana Renewable Energy Association; Natural Resources Defense Council; NextEra Energy Resources; Northwest Energy Coalition; Northwest National Marine Renewable Energy Center; Oregon Citizens’ Utility Board; Oregon State University; Oregon Tech; Oregon Wave Energy Trust; Orion Renewable Energy Group; Pacific Northwest National Laboratory; Principle Power; Puget Sound Energy; RES Americas Development; Stoel Rives, LLP; Vaisala/3Tier; Vestas Americas; and Western Resource Advocates.

\subsection{State Updates}

\subsubsection{Idaho}

As of the end of 2017, Idaho has a total installed wind capacity of 973 MW (American Wind Energy Association 2018), with more than \$2.1 billion in capital investment to the state and supporting between 501 and 1,000 direct and indirect jobs. In 2016, wind energy provided 15.16\% of all in-state electricity production (American Wind Energy Association 2017a).

Idaho has a larger percentage of smaller projects compared to neighboring states as many of the wind projects were developed under the PURPA limits. The major utility in the state, Idaho Power, has influenced policy changes at the Public Utilities Commission that limit project size and make changes to rates for standard PURPA contracts that increase costs for developers.

In September 2017, Idaho Public Utilities Commissioner Kristine Raper submitted written testimony to the U.S. House of Representatives Subcommittee on Energy arguing against PURPA's “must purchase" requirement and advocating for a number of changes to PURPA that would reduce project size, shorten contract length, and further restrict other aspects for projects to meet qualifying facilities requirements. ${ }^{171}$

Progress is being made in the areas of transmission and market development in the state. Idaho Power has committed to join the CAISO EIM. In February, the Idaho Public Utilities Commission gave partial approval to Idaho Power, authorizing a deferral account to track the costs and adopted Idaho Power's proposal to spread costs related to joining the EIM over a 10year period. However, the Public Utilities Commission would not rule yet on if the EIM could benefit customers, or pre-approve cost recovery for EIM costs, stating that to do so would, "remove the incentive for the company to implement the project in a prudent, least-cost manner."

${ }^{171}$ http://docs.house.gov/meetings/IF/IF03/20170906/106362/HHRG-115-IF03-Wstate-RaperK-20170906.pdf 
According to the Public Utilities Commission, Idaho Power hopes to join the EIM in April 2018. ${ }^{172}$

The Boardman-to-Hemmingway 500-kilovolt transmission line ${ }^{173}$ scored well in Idaho Power's integrated resource plan, and work is nearly finished with the state (Idaho and Oregon) and federal (Bureau of Land Management) siting processes. A record of decision regarding the project is expected from the Bureau of Land Management in 2017. This line will provide important connectivity between Wyoming and Idaho wind and the markets in Oregon and Washington.

Idaho has 2.4 MW of distributed wind capacity installed and no community wind projects. The state offers an income tax deduction for residential wind installations equal to $40 \%$ of the project cost in the first year and $20 \%$ in each of the following 3 years. The state's investor-owned utilities allow for net metering of wind systems up to 100 kilowatts $(\mathrm{kW})$ for commercial applications and $25 \mathrm{~kW}$ for residential applications.

Idaho participates in DOE's Wind for Schools project through the engagement of Boise State University, with the installation of seven school systems in the state. Boise State University also participated in DOE's 2014 and 2016 Collegiate Wind Competitions, as well as the 2015 and 2017 Collegiate Wind Competition Technical Challenges.

\subsubsection{Montana}

As of December 2017, Montana had a total installed capacity of 695 MW of wind energy (American Wind Energy Association 2018). These projects brought more than $\$ 1.4$ billion in capital investment to the state and supported between 501 and 1,000 direct and indirect jobs. In 2016, wind energy provided 7.57\% of all in-state electricity production (American Wind Energy Association 2017a).

Greenfield Wind, a 25-MW Qualifying Facility/PURPA project, came online in 2016. In addition, three 80-MW Qualifying Facilities in southern Carbon County were under construction ${ }^{174}$ in order to qualify for the Production Tax Credit and were expected to be completed in 2016. However, these projects have since been delayed by disputes with the off-taking utility about its obligation to take the power under PURPA (American Wind Energy Association 2016b). Big Timber, another 25-MW project, is technically under construction, although project development has stalled as developers work with the utility on contract terms. More than 5,000 MW of proposed projects are unable to move forward due to market conditions and transmission constraints.

\footnotetext{
172 http://www.puc.idaho.gov/press/170202_IPCEIM.pdf

173 https://www.boardmantohemingway.com/idaho_power_project_information.aspx

${ }^{174}$ Pryor Caves Wind, Mud Springs Wind, Horse Thief Wind Projects
} 


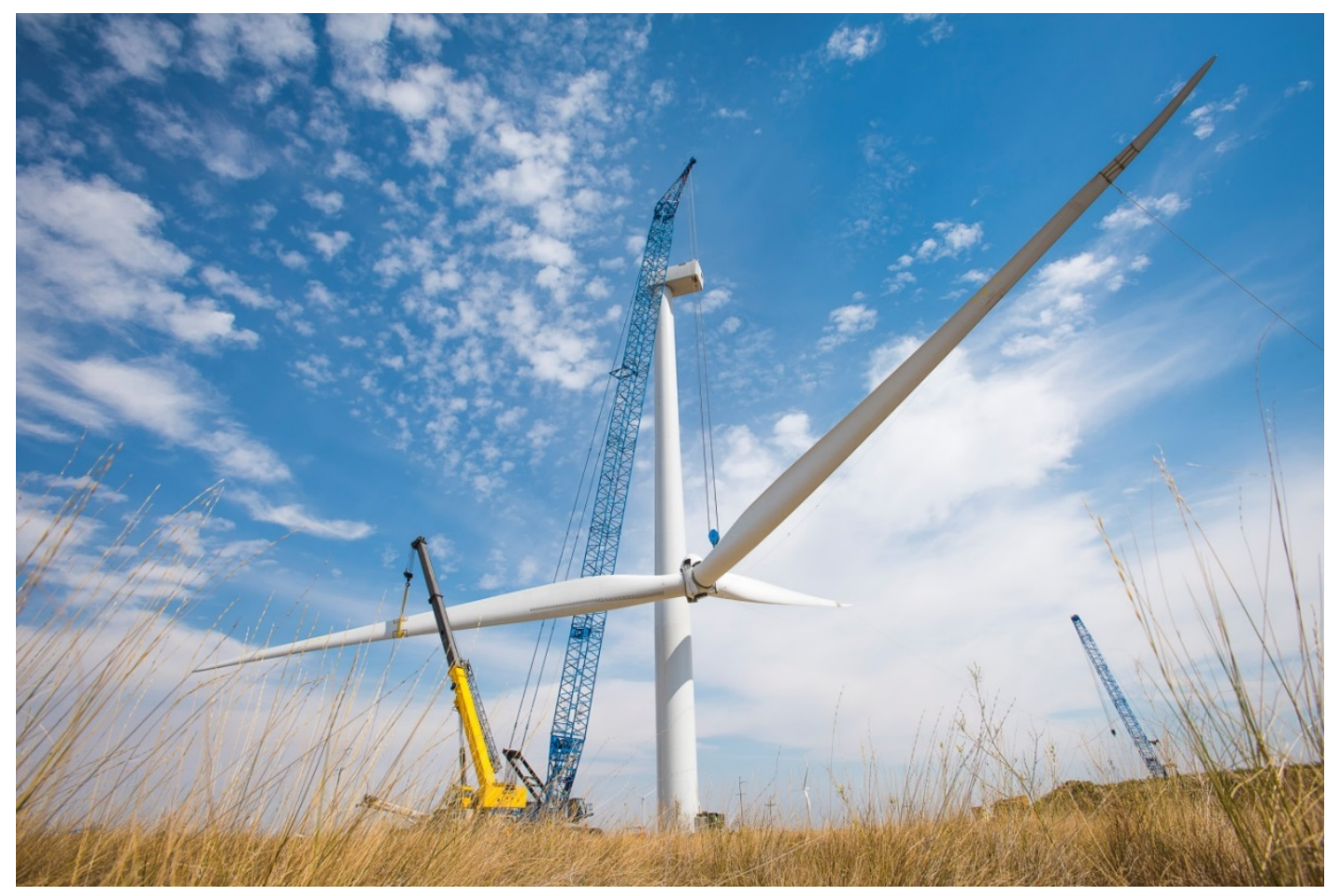

Figure 17. Greenfield Wind, a 25-MW facility located near Fairfield, Montana, was commissioned in September 2016. Photo from Dick Anderson Construction

Although the state has a large wind resource, ranking third nationally in total wind energy potential, the lack of transmission capacity to other states inhibits Montana from capturing it. This is especially problematic in eastern Montana, which has the lowest population as well as the highest wind resource. A growing local opportunity could be the ongoing load requirements from oil and gas development in the Bakken region. Governor Steve Bullock supports energy development and released an energy blueprint for the state in June 2016 that focuses intensely on reducing barriers to developing Montana's wind energy resource. The blueprint calls for increased regional engagement to solve transmission constraints and develop new markets for Montana’s wind energy resource. Governor Bullock holds a fairly conservative stance on carbon regulation, which would benefit wind but also impact Montana's coal industry. Public support is overwhelmingly in favor of wind energy development but at the same time supportive of existing coal generation.

In 2015, the Montana Public Service Commission approved a contract for Greycliff Wind, a 25-MW Qualifying Facility/PURPA project on NorthWestern Energy's system. The Commission approved the contract as part of its obligations under Montana law, which provides that Qualifying Facilities larger than the standard offer contract may petition the Commission to set rates if the developer and the utility are unable to agree to contract terms. Again, in 2016 the Commission approved potentially feasible contract terms for a large 80MW Qualifying Facility wind project, Vivaldi Springtime Wind Project. Since then, the commission has adopted a policy of limiting new Qualifying Facility contracts to 10 years or less in duration and reduced the standard offer project capacity limit to $3 \mathrm{MW}$, making new Qualifying Facility development infeasible. 
Physical transmission constraints, transmission policy, and RPS policy barriers continue to be the primary obstacles to substantially increasing development of Montana's wind resource. BPA's Montana Intertie transmission rate ${ }^{175}$ (sometimes also referred to as the Eastern Intertie transmission rate) effectively increases the cost of Montana wind by \$2 per megawatt-hour and strands existing transmission capacity from full utilization. The state's House of Representatives passed a resolution in support of eliminating the fee in April 2017; the transmission rate is still in place.

Washington's RPS appears to limit Montana wind from beyond BPA's service footprint from qualifying for Washington's RPS. However, an important recent opinion from Washington State Department of Commerce on the eligibility of dynamically transferred energy from beyond BPA's footprint may open the door for Montana wind to play a role in meeting Washington's renewable energy demand. A lack of market coordination and a lack of transmission infrastructure effectively limit the ability of Montana's best wind resource to play a role in the nearby Midcontinent Independent System Operator market or the more distant CAISO market.

While opposition to new transmission lines still exists, improvements to the siting process and some legislative changes have created a more favorable climate over the past few years. In the case of the Mountain States Transmission Intertie line, creating a citizens-based study group helped the average person's voice be heard in the siting process. Until recently, market forces have delayed development of the line and other major projects in the region, such as BPA's Montana-to-Washington project. The passing of the Clean Electricity and Coal Transition law in Oregon, as well as policy advances in Washington on a state carbon cap and Puget Sound Energy's ownership stake in Colstrip, have re-energized interest in these projects. The business case for BPA to finish the environmental work on the Montanato-Washington project has grown stronger, as has political pressure. While BPA did not eliminate the additional Montana Intertie charge in their recent rate case settlement, BPA is responding to stakeholders in the region. Resolutions from the Montana and the Washington legislatures were passed; the Montana Public Service Commission; Senators Cantwell, Tester, and Merkely; and Governor Bullock sent letters to BPA calling for elimination of this rate. In their final record of decision, BPA reduced the rate by $15 \%$ and committed to engaging in public workshops to address transmission barriers for Montana wind.

Efforts to provide access for Montana's wind potential to West Coast load centers saw some gains over the past year. At its April 12 stakeholder meeting in Portland, Northern Tier Transmission Group accepted a study request from Renewable Northwest and NW Energy Coalition to analyze "dynamic stability" and voltage concerns and solutions associated with retiring Colstrip Units 1, 2, and 3 and replacing it with equal amounts of wind generation. The draft study found that, under certain assumptions, the system performed equally well during reliability events with wind replacing the three Colstrip units.

\footnotetext{
175 https://www.bpa.gov/secure/RateCase/openfile.aspx?fileName=BP-18-A-

02.pdf\&contentType=application $\% 2 \mathrm{fpdf}$
} 
Other transmission developments have also moved forward. The Upper Great Plains region of the Western Area Power Administration (Western) joined the Southwest Power Pool's organized market. Although Western's transmission presence in Montana is weak, this could improve in the future, and the access to an organized market is an important development. Also, the owners of the Montana Alberta Tie Line have proposed an upgrade to that 230-kilovolt line from Montana to the Alberta Independent System Operator. Planned and potential coal plant retirements should also increase transmission capacity available for wind energy export over the next 2 to 5 years.

In addition, Northwestern Energy is studying the benefits of joining the CAISO EIM. Joining would be an important development for improving the ability to efficiently integrate Montana wind into the grid.

Montana has a 15\% by 2015 RPS. Northwestern Energy, the largest utility in the state, met the 2015 RPS target mostly through generation from seven wind projects with a total installed capacity of $213.4 \mathrm{MW}$. The $15 \%$ target remains in effect.

As in other western states, impact on sage grouse populations is a concern when siting energy projects. Montana’s Sage Grouse Conservation Strategy, adopted in anticipation of Endangered Species Act listing decision by the U.S. Fish and Wildlife Service (USFWS), could affect wind energy development in Montana. The strategy calls for wind energy development to be avoided in all sage grouse core areas. Since then, in an action that provides some additional certainty for wind development, the USFWS announced the results of its status review. The review found "that the greater sage-grouse remains relatively abundant and well-distributed across the species' 173-million-acre range” and "does not face the risk of extinction now or in the foreseeable future." As a result, the USFWS concluded that the greater sage grouse should not be listed under the Endangered Species Act (U.S. Department of the Interior 2015).

Montana has 4.9 MW of distributed wind capacity installed, primarily consisting of turbines rated at $100 \mathrm{~kW}$ or less. Gordon Butte, the only community wind project, has an interconnection and power purchase agreement with NorthWestern Energy. Montana offers a tax credit up to $\$ 1,000$ per household for the installation of a residential wind turbine. Montana's investor-owned utilities allow net metering of wind systems up to $50 \mathrm{~kW}$ in capacity.

Montana participates in DOE's Wind for Schools project through the engagement of Montana State University, with 11 school systems installed in the state. The University of Montana also provides wind energy curricula.

Note that Eastern Montana is also supported by the Midwest Regional Resource Center.

\subsubsection{Oregon}

As of December 2017, Oregon has a total installed capacity of 3,213 MW (American Wind Energy Association 2018). These projects brought more than $\$ 6.5$ billion in capital investment to the state and supported between 2,101 and 3,000 direct and indirect jobs. In 2016, wind energy provided 12\% of all in-state electricity production (American Wind Energy Association 2017a). 
The 10-MW Chopin Wind Project came online in Umatilla County in September 2016, and a cluster of five 10-MW projects was completed in Baker County in early 2017.

Other developments have stalled in recent years due to factors including depressed demand for power, low natural gas prices, uncertainty about the persistence of federal policy, and utilities fulfilling their near-term RPS compliance targets. Because of this delay in construction activity, some projects that were already approved through state and county processes need to apply for permit extensions or let their existing permits expire. In 2015 alone, two projects with a total capacity of 1,002 MW either withdrew their applications or let their notice of intent expire.

There are signs of a return to positive market conditions for wind development in the state. The passage in 2016 of the Clean Electricity and Coal Transition law (SB 1547-B) added a 2040 target of 50\% to the RPS for large investor-owned utilities. The RPS expansion legislation also included an incentive for taking early compliance action, which coincided with the extension of the federal Production Tax Credit; along with the scheduled retirement of the Boardman and Centralia coal generation facilities, this is leading to an increased appetite for renewable energy resources in Oregon. Additional legislation was proposed in early 2017 that could also impact energy generation in the state. If passed, SB557 ${ }^{176}$ would rescind Oregon's current greenhouse gas emissions goals and require the state's Environmental Quality Commission to "adopt by rule statewide greenhouse gas emissions goal for 2025 and limits for years 2035 and 2050."

In November 2016, Portland General Electric submitted an integrated resource plan seeking about 500 MW of wind. In August 2017, the Oregon Public Utility Commission decided that this amount was too large but asked the utility and stakeholders to rework a new renewable proposal before the end of the year. PacifiCorp released its integrated resource plan in April 2017, seeking upwards of 1,270 MW of new wind, as well as repowering nearly 1 gigawatt of its wind fleet. The Oregon Public Utility Commission approved PacifiCorp's request for proposal for these resources, but that approval is conditional on the commissioners determining that the utility's plan is reasonable, which they will decide in December 2017.

Over the past year, the Oregon Public Utility Commission has seen a lot of activity regarding its implementation of PURPA. For example, the Commission recently reaffirmed its policy of requiring utilities to offer Qualifying Facilities 15 years of fixed prices in PURPA contracts. The Commission is reviewing PacifiCorp's methodology to calculate PURPA rates for large Qualifying Facilities willing to transfer renewable energy credits to the utility. Finally, the Commission announced an upcoming investigation into the interaction between the integrated resource plans and PURPA. The outcome of this investigation will impact how Qualifying Facilities are compensated.

Transmission and market issues in the region continue to impact wind development in the state. In late 2015, the Northwest Power Pool, which includes many large utilities in the region, and BPA announced that they would cease efforts to explore a Northwest EIM option. This led larger investor-owned utilities in the region to explore joining the EIM operated by CAISO as an alternative. In Oregon, PacifiCorp is participating in the CAISO EIM and Portland General

${ }^{176}$ https://olis.leg.state.or.us/liz/2017R1/Measures/Overview/SB557 
Electric is on track to join in October 2017, improving the integration of wind resources. A handful of public power utilities are also considering joining the EIM.

As in other Western states, impact on sage grouse populations is a consideration when siting wind projects. Oregon is developing a state plan for sage grouse conservation that will affect the potential for wind energy development in the southeastern quadrant of the state. Oregon is attempting to avoid the core area exclusion approach used in other states by formulating a new regulatory approach and enhancing the compensatory mitigation system. Toward that end, in September 2015, Governor Kate Brown signed an executive order adopting the Oregon SageGrouse Action Plan. ${ }^{177}$ That same month, in an action that provides some additional certainty for wind development, the USFWS announced the results of their status review. The review found "that the greater sage grouse remains relatively abundant and well-distributed across the species' 173-million-acre range" and "does not face the risk of extinction now or in the foreseeable future.” As a result, USFWS concluded that the greater sage grouse does not need to be listed under the Endangered Species Act (U.S. Department of the Interior 2015).

Oregon has 4.9 MW of distributed wind capacity installed, primarily located in territory covered by the Energy Trust of Oregon's incentive program. Oregon has a single 9-MW community wind project, PaTu Wind, which sells power through a power purchase agreement with Portland General Electric and a long-term transmission contract with Bonneville Power. Like other states in the region, additional distributed wind projects are limited by high installed costs and community wind projects are challenged by low power purchase agreement prices and lack of the investment tax credit cash grant.

${ }^{177}$ http://oe.oregonexplorer.info/ExternalContent/SageCon/SageCon_Action_Plan_Main_Body_FINAL.pdf 


\section{Offshore Wind in the Pacific Northwest: Strategies and Considerations}

When the nation's first offshore wind project came online in late 2016, it ushered in a new energy era on the east coast of the United States, but it also left many pondering how to make similar progress on the other side of the country. With contributions from the Northwest Regional Resource Center's Offshore Wind Strategy Team (which receives funding support from the U.S. Department of Energy) and a multitude of their partners, the Oregon Department of Energy released a report that delves into this topic and outlines the necessary steps to foster the development of offshore wind in the Pacific Northwest. In May 2017, the Oregon Department of Energy published Offshore Wind in the Pacific Northwest: Strategy Recommendations, which examines the current market of offshore wind in terms of the state of the technology, regulatory practices, resource potential, and existing infrastructure.

"This comprehensive report is the result of regional collaboration between energy and planning experts in state government in Oregon and Washington, researchers at Pacific Northwest universities and national laboratories, renewable energy advocates, and the offshore wind industry," said Diane Broad, senior policy analyst at the Oregon Department of Energy. "The seven strategic actions recommended in the report aim to improve prospects for offshore wind development in the Pacific Northwest over the next 10 years. Some actions focus on utility engagement and transmission planning - areas that have current actions on which to build. Other actions break new ground, such as developing a port and community readiness plan to attract offshore wind developers, as well as completing a regulatory roadmap and matrix that will inform a step-by-step guide for offshore wind developers to navigate the regulatory and permitting requirements."

Development of the Pacific Northwest's offshore wind potential has the ability to transform the renewable energy landscape of the western United States while supporting new jobs in an innovative field that has only begun to be realized on a national level.

Principle Power ceased development of the 30-MW WindFloat Pacific project, the West Coast's first proposed offshore wind project, in September 2016. The development was formerly one of DOE's Offshore Wind Advanced Technology Demonstration Projects, but high costs prevented Principle Power from securing a power purchase agreement in the time required to remain in the program. Interest in offshore wind on the West Coast has been limited due to the unique technology required to install turbines in the deep waters of the Pacific Ocean. This demonstration project proposed the use of floating turbine platforms to overcome the water depth issue and establish the technical viability for future offshore wind installations in this area.

The offshore wind resource along the southern Oregon coast and northern California Coast is among the best in the world. California has an RPS goal of 50\% by 2030, and most California utilities are well-positioned to meet that a decade ahead of schedule. An increase in the RPS goal for California is likely in the coming years, as evidenced by legislation to increase to a $100 \%$ RPS that has been introduced in the 2017 California legislative session. The Western Electricity Coordinating Committee recognizes the strong resource potential of offshore wind along the Northwest and Northern California coasts and announced early in 2017 that a scenario of 3,000 MW of offshore wind in this region would be included in the studies supporting the transmission expansion policy process, led by the Transmission Expansion Planning Policy Committee group. The outcome of this study is anticipated to spark a regional dialogue about the relative merits of transmission investments that would lower the barriers to offshore wind deployment in the Northwest. 
To analyze the employment and economic potential for floating offshore wind along the West Coast, BOEM commissioned NREL to analyze two hypothetical, large-scale deployment scenarios for Oregon: 5,500 MW of offshore wind deployment in Oregon by 2050 (Scenario A) and 2,900 MW of offshore wind by 2050 (Scenario B). According to the Scenario A analysis, deploying 5,500 MW of floating offshore wind in Oregon and assuming a modest in-state supply chain could support between $\$ 4.6$ billion and $\$ 5.7$ billion in construction-phase economic activity to Oregon's gross domestic product and support between 44,000 and 66,000 full-time equivalent construction-phase job-years between 2020 and 2050 (Jimenez et al. 2016c). BOEM also commissioned NREL to conduct another economic impact analysis with the same parameters, this time focused on the impacts to the seven Oregon coastal counties: Clatsop, Tillamook, Lincoln, Lane, Douglas, Coos, and Curry. According to the Scenario A analysis, deploying 5,500 MW of floating offshore wind in Oregon could add \$1.6 billion to \$2.8 billion to the gross domestic product of the coastal counties from 2020 to 2050 in construction-phase activities and support 18,000 to 33,000 full-time equivalent construction-phase job-years between 2020 and 2050 (Jimenez et al. 2016b).

Columbia Gorge Community College was one of the original colleges offering wind technician training programs: a 9-month certificate and a 2-year Associate of Applied Science degree in renewable energy. Recently the college included a classroom component that offers a series of free videos on YouTube that cover all aspects of Columbia Gorge’s Renewable Energy Technology program.

Oregon Tech offers Bachelor of Science and Master of Science degree programs in Renewable Energy Engineering. The degree program was established in 2005 and expanded to include a master's degree program in 2012.

\subsubsection{Washington}

As of December 2017, Washington has a total installed capacity of 3,075 MW (American Wind Energy Association 2018). These projects brought more than $\$ 6.1$ billion in capital investment to the state and supported between 1,001 and 2,000 direct and indirect jobs. In 2016, wind energy provided 7.13\% of all in-state electricity production (American Wind Energy Association 2017a).

Similar to other states in the Northwest, new project development has slowed due to factors such as depressed demand for power, low natural gas prices, uncertainty about the persistence of federal policy, and utilities fulfilling their near-term RPS compliance targets. However, recent policy developments should create opportunities for wind in the state. On September 15, 2016, Washington Department of Ecology adopted the Clean Air Rule. These state-wide standards to cap and reduce greenhouse gas emissions from significant in-state stationary sources became effective on October 17, 2016. Renewable energy credits from Washington projects are projected to be a least-cost compliance mechanism. Furthermore, planned coal retirements will create additional market drivers for wind in the near- to mid-term future.

Efforts to create opportunities for wind development also continue through active involvement in the integrated resource plans and other regulatory issues, ensuring that utilities use accurate wind energy information so that wind is fairly considered as a resource option. In Washington, several developments over the past year with Puget Sound Energy illustrate how efforts in the regulatory 
sphere hold promise for wind and other renewables. In August 2016, Puget Sound Energy filed with the Washington Utilities and Transportation Commission to create additional voluntary renewable energy products and a carbon-free option targeted at large customers and government entities.

Puget Sound Energy began transacting in the CAISO EIM in October 2016, improving its ability to integrate wind efficiently. Some Washington public power utilities are also considering joining the energy imbalance market. BPA has facilitated other utilities’ EIM participation by accommodating the new market's use of the federal transmission system. BPA may also increase its ability to interact with the new market.

Washington has 12.8 MW of distributed wind capacity installed, of which 10.4 MW are also community wind projects (Coastal Energy Project and Swauk Wind). Washington State offers a production-based incentive of \$0.12 per kilowatt-hour for net-metered wind systems up to 100 $\mathrm{kW}$; however, the high installed cost of these systems remains a barrier. The incentive expires in June 2020, and efforts are underway to renew and expand this program to include community wind; previous efforts in the 2015 and 2016 legislative sessions were unsuccessful.

Seattle University was selected to participate in DOE’s Collegiate Wind Competition 2018.

\subsubsection{Wyoming}

By the end of December 2017, Wyoming had 1,489 MW of installed wind capacity (American Wind Energy Association 2018), representing total capital investment of \$3.1 billion and supporting between 501 and 1,000 direct and indirect jobs. In 2016, wind energy provided 9.42\% of all in-state electricity production (American Wind Energy Association 2017a). One 80-MW project came online in October 2016, the first wind project completed in Wyoming since 2010. Wyoming has no RPS or renewable energy goals.

As with other states in the region, transmission constraints limit development, although three large transmission projects have been proposed to deliver power to larger markets. One of these, the 600-kilovolt direct-current TransWest Express Transmission Line, is being designed to carry up to 3,000 MW from south-central Wyoming, near Rawlings, and ending southeast of Las Vegas (U.S. Bureau of Land Management 2016b). Several large wind projects have been proposed for Wyoming to utilize that transmission capacity if the new line project moves forward. More information on these projects is included in the Four Corners Region section.

Other siting considerations for wind development in Wyoming include a state tax on wind energy generated and project siting concerns relating to sage grouse and eagles. Wind education programs in the state include programs at the University of Wyoming and Larimer County Community College, one of the original colleges offering certificate programs for wind turbine technicians.

Wyoming has 5.9 MW of distributed wind capacity installed and no community wind projects. State law allows for net metering of wind systems up to 25 kilowatts in capacity; however, there are no other state incentives for distributed wind. 
Note that the Four Corners Wind Resource Center also supports activities in Wyoming; in this report, Wyoming updates are included in the Northwest Region's section. 


\section{Southeast Region}

Colleagues from the Southeast Wind Energy Resource Center (SWERC) and the National Renewable Energy Laboratory (NREL) collaborated to provide the following assessment of the state of the wind industry in this region.

The SWERC ${ }^{178}$ encompasses the following states: Alabama, Arkansas, Florida, Georgia, Kentucky, Louisiana, Mississippi, North Carolina, South Carolina, Tennessee, and Virginia (see Figure 4). The Regional Resource Center (RRC) works to advance the wind industry in the Southeast by providing objective, fact-based information to stakeholders, engaging electric utilities, engaging on wind energy permitting processes, and preserving access to quality wind resources, both onshore and offshore. The RRC is a joint effort of the Southeastern Wind Coalition and several partners, including the North Carolina Clean Energy Technology Center at North Carolina State University, Clemson University, Coastal Carolina University, Georgia Institute of Technology, and James Madison University (JMU). These partners are reliable sources of unbiased wind energy information and have a history of stakeholder engagement in the region.

\subsection{Overview of Regional Wind Market}

This section provides an overview of the wind industry in the region. Although wind development in the Southeast has been limited (Table 25), it should be noted that improved technology and accessing the wind resource at higher above-ground heights allow for geographic expansion of wind development into areas such as the Southeast, which historically was categorized as having a poor wind resource and little potential for wind development. The U.S. Department of Energy's (DOE's) Wind Energy Technologies Office works to advance nextgeneration wind turbine technologies such as taller towers and larger rotors.

New maps of potential wind capacity are available for a 2014 industry standard wind turbine installed on a 110-m tower, which represents plausible current technology options, and a wind turbine on a 140-m tower), which represents near-future technology options. ${ }^{179}$ The 2015 DOE report Enabling Wind Power Nationwide provides extensive discussions on the expanding opportunities of wind development, particularly across the Southeast and Gulf Coast (U.S. Department of Energy 2015d). Stakeholders can also consult the DOE's interactive Wind Vision Study Scenario Viewer ${ }^{180}$ to learn more about state-specific costs, benefits, and other impacts from wind energy development related to the Wind Vision scenarios.

\footnotetext{
178 http://www.sewind.org/

179 https://windexchange.energy.gov/maps-data

180 http://en.openei.org/apps/wv_viewer/
} 
Table 25. Key Statistics for States in the Southeast Wind Energy Resource Center Region

\begin{tabular}{|c|c|c|c|c|c|c|c|c|c|c|c|}
\hline & $A L$ & AR & FL & GA & KY & LA & MS & NC & SC & $\mathrm{TN}$ & VA \\
\hline $\begin{array}{l}\text { Installed Wind } \\
(\mathrm{MW}) \text {, End of } \\
4 \mathrm{Q} 17^{181}\end{array}$ & 0 & 0 & 0 & 0 & 0 & 0 & 0 & 208 & 0 & 29 & 0 \\
\hline $\begin{array}{l}2017 \text { Wind Power } \\
\text { Capacity } \\
\text { Additions (MW) }{ }^{182}\end{array}$ & 0 & 0 & 0 & 0 & 0 & 0 & 0 & 208 & 0 & 0 & 0 \\
\hline $\begin{array}{l}\text { Wind Capacity } \\
\text { under } \\
\text { Construction } \\
\text { (MW), End of } \\
\text { 4Q17 } 183\end{array}$ & 0 & 0 & 0 & 0 & 0 & 0 & 0 & 0 & 0 & 0 & 0 \\
\hline $\begin{array}{l}\text { Projected } \\
\text { Potential Capacity } \\
\text { (MW), } 80 \text { m, 30\% } \\
\text { Capacity Factor }\end{array}$ & 118 & 9,200 & .4 & 130 & 61 & 410 & 0 & 808 & 185 & 309 & 1,793 \\
\hline $\begin{array}{l}\text { Projected } \\
\text { Potential Capacity } \\
\text { (MW), } 100 \text { m, } \\
\text { 30\% Capacity } \\
\text { Factor }\end{array}$ & 568 & 49,962 & .4 & 294 & 699 & 2,840 & 0 & 1,500 & 1,215 & 817 & 3,466 \\
\hline $\begin{array}{l}\text { Wind Potential w/ } \\
\text { Future Turbine } \\
\text { Technology } \\
\text { (Terawatt- } \\
\text { Hours/Year) }\end{array}$ & 715 & 839 & 576 & 698 & 525 & 693 & 721 & 366 & 393 & 449 & 258 \\
\hline $\begin{array}{l}\text { Distributed Wind } \\
\text { Capacity, as of } \\
\text { December } 2016 \\
(\mathrm{MW})^{184}\end{array}$ & 0 & .104 & 0.3 & 0.01 & .07 & .100 & 0 & 0.2 & 0.01 & 0.01 & 0.4 \\
\hline $\begin{array}{l}\text { Proposed } \\
\text { Offshore Wind } \\
\text { Projects (MW), as } \\
\text { of December } \\
2016^{185}\end{array}$ & 0 & $\mathrm{n} / \mathrm{a}$ & 0 & 0 & $\mathrm{n} / \mathrm{a}$ & 0 & 0 & 0 & 0 & $\mathrm{n} / \mathrm{a}$ & 12 \\
\hline
\end{tabular}

Sources: American Wind Energy Association, Southeastern Wind Coalition, U.S. DOE

\footnotetext{
${ }^{181}$ American Wind Energy Association 2018

${ }^{182}$ American Wind Energy Association 2018

${ }^{183}$ American Wind Energy Association 2018

${ }^{184}$ Distributed wind project capacity is defined as cumulative capacity, 2003-2016 (U.S. Department of Energy 2017a).

${ }^{185}$ American Wind Energy Association 2017b
} 


\subsubsection{Renewable Portfolio Standards}

Of the states located in the SWERC's area, only North Carolina has a renewable portfolio standard (RPS). South Carolina and Virginia have goals, and the remaining eight states have neither in place. No new RPS policies were adopted in 2017 in the Southeast.

Table 26. RPS Overview for States Served by the Southeast Wind Energy Resource Center

\begin{tabular}{ll}
\hline & RPS \\
\hline Alabama & None \\
\hline Arkansas & None \\
\hline Florida & None \\
\hline Georgia & None \\
\hline Kentucky & None \\
\hline Louisiana & None \\
\hline Mississippi & None \\
\hline & $12.5 \% \times 2021$ (investor-owned utilities) \\
\hline North Carolina & $10 \% \times 2018$ (co-ops \& munis) \\
\hline South Carolina & Goal of $2 \%$ by 2021 \\
\hline Tennessee & None \\
\hline Virginia & Goal of $15 \% \times 2025$ \\
\hline
\end{tabular}

Source: Database of State Incentives for Renewables \& Efficiency

\subsubsection{Communities with $100 \%$ Renewable Energy Commitments}

Many state public utility commissions are working with utilities to choose the direction of their energy portfolios. While some states have mandated and voluntary renewable energy goals or standards, some cities have gone a step further to create their own commitments to clean energy, some of which exceed levels established by their states. Some communities within the Southeast Region have made $100 \%$ renewable energy commitments (Table 27).

Table 27. Communities Served by the Southeast Regional Resource Center with $100 \%$ Renewable Energy Commitments

\begin{tabular}{lll}
\hline City & State & Target Year \\
\hline Abita Springs & LA & End of 2030 \\
Atlanta & GA & 2035 \\
Columbia & SC & 2036 \\
\hline Hillsborough & NC & End of 2050 \\
Orlando & FL & 2050 \\
Sarasota & FL & 2045 \\
St. Petersburg & FL & 2032 \\
\hline
\end{tabular}

Source: Sierra Club 


\subsection{Workforce Development}

Robust programs at JMU, land-based wind programs at Virginia Technical University, offshore wind programs at Clemson University and Georgia Technical University, and distributed wind programs at Appalachian State University provide a diversity of wind energy education in the region.

As part of the Wind for Schools project in Virginia, JMU works with eight affiliate primary and secondary schools, eight host schools, and seven partner schools. In the past year, JMU staff members worked closely with one school to help install wind technology on the campus.

JMU staff members have also conducted teacher trainings and presented to students about wind energy. JMU houses an extensive lending library of energy classroom kits that cover topics from electricity basics to wind and solar energy generation. Since 2010, JMU staff trained more than 1,300 teachers and reached nearly 8,500 students through educational tours, events, and classroom visits, including two KidWind Challenges.

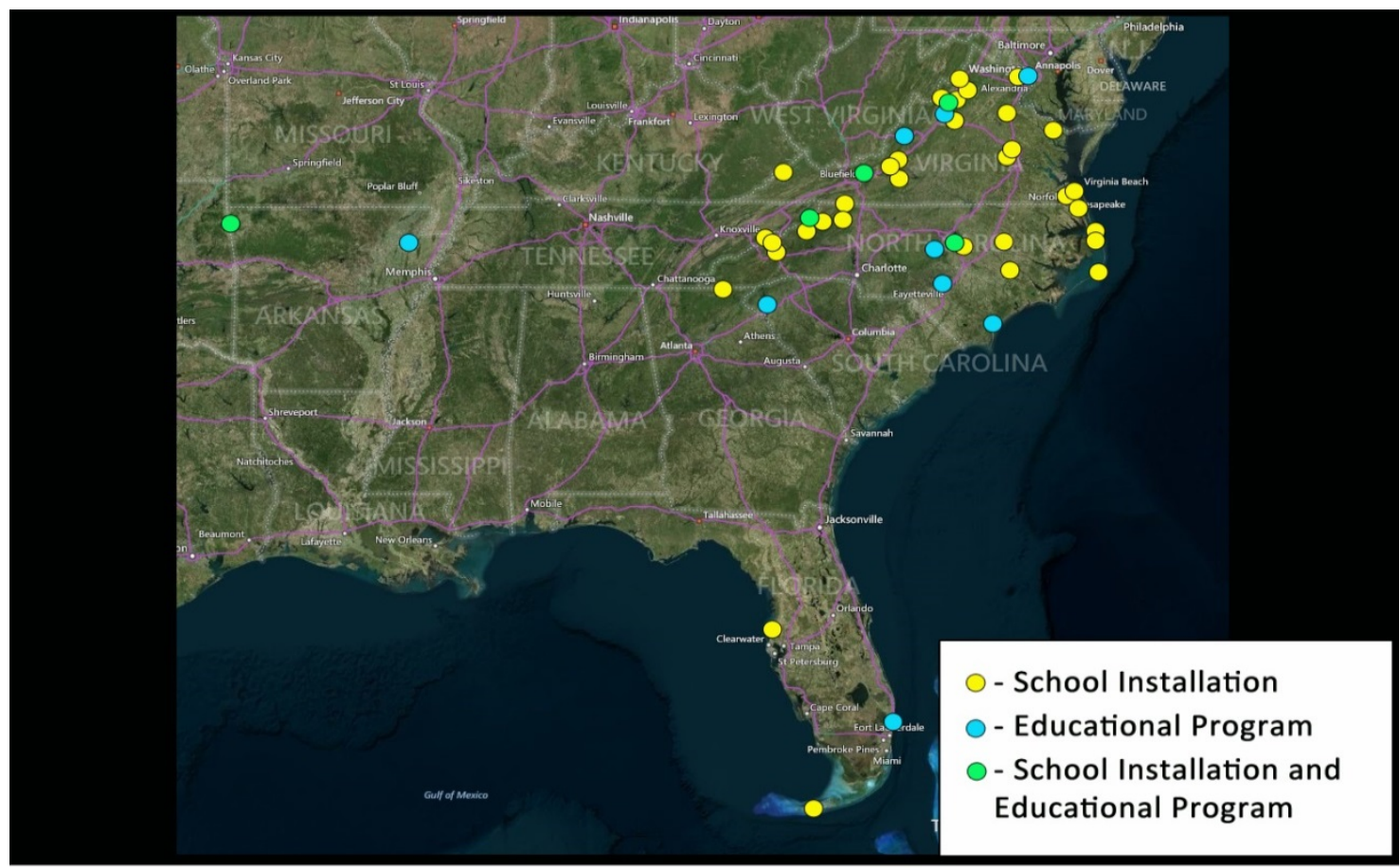

\section{Southeast Wind Energy Resource Center} (VA, KY, TN, NC, SC, GA, AL, MS, AR, LA, FL)

Figure 18. Map of school wind turbine projects, educational programs, and locations with both wind turbines and educational programs within the Southeast Wind Energy Resource Center's area

Lastly, JMU staff taught wind energy-related materials in two courses and advised two teams of JMU senior capstone project students and two high school senior project students on windrelated research. JMU staff also advised five summer interns on wind-related work. Appalachian 
State University also had an active Wind for Schools program in North Carolina, providing teacher training and technical support to schools interested in installing wind turbines at their locations.

Clemson University’s South Carolina Electric \& Gas Energy Innovation Center ${ }^{186}$ is a wind turbine drivetrain testing and grid simulator facility that completed construction in 2013. In October 2016, a ribbon-cutting ceremony was held across the street from the Energy Innovation Center to commemorate the grand opening of the Zucker Family Graduate Education Center. The new facility offers master's degrees and doctorates in electrical engineering, computer engineering, mechanical engineering, computer science, and digital production arts. Programs at the center are expected to expand to 200 students, 12 faculty, and 40 researchers on staff. Students and employees can engage in wind turbine research efforts at the nearby Energy Innovation Center.

Additional educational activities are described in more detail in the state sections below. The WINDExchange website also offers information and interactive maps regarding workforce development, the DOE Collegiate Wind Competition, DOE's Wind for Schools project, school wind project locations, and locations of education and training programs in the SWERC region and other states. ${ }^{187}$

\subsection{Manufacturing and Economic Development}

Although the Southeast has faced challenges maximizing the benefits of its wind resource, a robust manufacturing base has developed throughout the region. NREL researchers compiled the following wind energy manufacturing data for this region as part of DOE's annual wind market report effort (U.S. Department of Energy 2017c).

Additional economic impacts from wind development include the capital investment, jobs supported, tax revenues paid, payments in lieu of taxes, and land lease payments from wind developers during construction and the ongoing maintenance of wind plants. The American Wind Energy Association performs modeling work that identifies the impacts of wind-related investment. Table 29 summarizes the total jobs (including construction jobs in 2016) and capital investment in wind farms in the SWERC states. Examples of economic impacts are provided in the state overviews below.

\footnotetext{
186 http://clemsonenergy.com/

187 http://apps2.eere.energy.gov/wind/windexchange/schools/
} 
Table 28. Wind-Related Manufacturing Overview for States Served by the Southeast Wind Energy Resource Center

\begin{tabular}{llll}
\hline Name & City & State & Component \\
\hline Molded Fiber Glass & Opp & AL & Enclosures \\
\hline LM Wind Power & Little Rock & AR & Blades \\
\hline Cobham Sliprings & Jupiter & FL & Slip rings \\
\hline GE Energy & Pensacola & FL & Turbine (nacelle assembly) \\
\hline Jupiter Group & Pensacola & FL & Nacelle covers and spinners \\
\hline Hailo LLC & Elberton & GA & Climbing devices \\
\hline ZF Group & Gainesville & GA & Gearboxes \\
\hline ABB & & & Electronic protection and \\
\hline AKG & Senataboia & MS & control products \\
\hline American Roller Bearing Company & Hebane & NC & Generator components \\
\hline American Roller Bearing Company & Morganton & NC & Bearings \\
\hline Comer Industries & Charlotte & NC & Yaw, pitch control systems \\
\hline Southwire & Huntersville & NC & Electrical \\
\hline ILJIN & Greer & SC & Bearings \\
\hline IMO Group & Charleston & SC & Slew rings and drives \\
\hline Kemet & Simpsonville & SC & Inverters \\
\hline Morgan AM\&T & Greensville & SC & Carbon brushes \\
\hline Timken & Union & SC & Bearings \\
\hline Thomas \& Betts Corp. & Memphis & TN & Fasteners \\
\hline BGB Technology & Chesterfield County & VA & Slipring assembly \\
\hline
\end{tabular}

The Southeastern Wind Coalition has helped to further highlight the manufacturing base in the region by undertaking an effort to map the full supply chain for wind in the Southeast. This map shows the location of each facility, the parts of the supply chain the facility contributes to, and information about the company. ${ }^{188}$ The map has allowed the Southeastern Wind Coalition to connect with new manufacturers and to leverage their efforts helping with plant tours and calls to state and local elected officials who are considering wind-related policy. Education and outreach around manufacturing is further benefited by dedicated fact sheets that highlight the number of companies, jobs, and investment around the wind energy supply chain in the region. These fact sheets discuss the level of economic development wind can create locally. ${ }^{189}$

\footnotetext{
188 www.sewind.org/map/find-companies

189 http://www.sewind.org/resources/fact-sheets
} 
Table 29. Economic Impacts of Wind Development in States Served by the Southeast Wind Energy Resource Center

\begin{tabular}{lll}
\hline State & Direct and Indirect Jobs Supported & Total Capital Investment \\
\hline Alabama & $101-500$ & $\mathrm{n} / \mathrm{a}$ \\
\hline Arkansas & $501-1,000$ & $\mathrm{n} / \mathrm{a}$ \\
\hline Florida & $1,001-2,000$ & $\mathrm{n} / \mathrm{a}$ \\
\hline Georgia & $101-500$ & $\mathrm{n} / \mathrm{a}$ \\
\hline Kentucky & $101-500$ & $\mathrm{n} / \mathrm{a}$ \\
\hline Louisiana & $101-500$ & $\mathrm{n} / \mathrm{a}$ \\
\hline Mississippi & $1-100$ & $\mathrm{n} / \mathrm{a}$ \\
\hline North Carolina & $1,001-2,000$ & $\mathrm{n} / \mathrm{a}$ \\
\hline South Carolina & $101-500$ & $\mathrm{n} / \mathrm{a}$ \\
\hline Tennessee & $101-500$ & $\$ 39$ million \\
Virginia & $101-500$ & $\mathrm{n} / \mathrm{a}$ \\
\hline
\end{tabular}

Source: American Wind Energy Association 2017a, as of 2016

\subsection{Key Stakeholder Groups and Development Challenges}

The SWERC targets these stakeholder groups:

Utilities. Electric utilities are a critical stakeholder for all market sectors of wind energy, especially in the Southeast. The large, vertically integrated, regulated utilities are major economic drivers and have connections at the highest levels of state leadership. As a result, they have tremendous influence in energy policy and permitting, and that affects land-based, offshore, and distributed wind energy.

Duke Energy hosted an October 2016 meeting of the SWERC's Utility Advisory Group in Charlotte, North Carolina, to present on relevant developments for wind energy in the Southeast. The speakers addressed tall-tower technology, wind resource mapping at greater heights, and economic considerations for wind-generated electricity. Keystone's new tower technology allows for rolled steel to be welded in a tapered tube on site. This is one of the promising technologies being explored by DOE to create cost-effective tall towers, critical components for long-term wind development in the Southeast. Vaisala released its initial high-altitude measurement findings at three Southeast locations. Findings indicate very strong wind shear between 100 and 140 meters, which is a promising development for the industry. The Southeastern Wind Coalition and Vaisala continue to work together to create a verified highaltitude wind map of the region. Lastly, NREL debuted new levelized cost of energy maps for the region that can help developers and utilities determine where the greater cost of higher towers is justified by significant increases in wind resource.

The SWERC hosted an April meeting of the Utility Advisory Group in North Carolina to discuss the history and development of the Amazon Wind Farm U.S East project, the first large utilityscale wind farm in the Southeast. Craig Poff, business developer for Avangrid Renewables in the 
region, presented an overview of the history of the project and lessons learned. The meeting also featured speakers to talk about other aspects of the project including the turbines, siting and engineering, interconnection, and underground vs. overhead transmission. After the presentations, Utility Advisory Group participants were given the opportunity to tour the Amazon Wind Farm and learn more about onsite logistics from Poff.

Federal and state decision makers. State policies have been an important driver for renewable energy demand creation in the United States. So far in the Southeast, only North Carolina passed an enforceable RPS. The value of and need for unbiased, relevant, and actionable information provided to state policymakers will prove critical in helping to ensure the appropriate development of the region's wind resources.

Local decision makers. County commissioners, city managers, town managers, and other local leaders can have a tremendous influence on the ability to deploy wind energy in appropriately sited locations. For example, a land-based project by Apex Wind in Alabama was effectively stopped by opposition from the county commission. This is a critical audience for delivering unbiased and fact-based information to allow informed decisions about wind energy projects and related policies in their jurisdiction.

The Southeastern Wind Coalition provided fact-based wind power information to county commissioners in Botetourt County, Virginia, for the consideration of their wind ordinances. This information directly resulted in community-oriented ordinance measures being passed. Apex’s Rocky Forge Wind project in Botetourt County is the first wind project to have its permit by rule application approved by the Virginia Department of Environmental Quality.

Industry. Wind industry developers, consultants, and service and supply chain companies are a strong and historically underutilized ally in efforts to advance responsible wind energy development. As the voice of jobs and economic development, they have considerable influence with decision makers and leaders. They are also a valuable source of technical information.

The SWERC works to provide information to address the following wind energy development considerations and market barriers that are prevalent in this region. Each barrier is followed by a more detailed description specific to the Southeast region and an example of the SWERC's work to address the barrier with their stakeholders.

Information on local economic benefits is needed. As part of SWERC activities to increase awareness of the economic benefits and considerations of wind development in the region, it has been important to include outreach to state and local decision makers. As an example, the Southeastern Wind Coalition continues to update the Southeast Wind Industry Supply Chain Database \& Map $^{190}$ it released in November 2015 that offers public access to suppliers across the value chain (education, research, engineers, services, etc. in addition to typical original equipment manufacturers and parts suppliers). This map is primarily used to demonstrate the expansive economic impact of wind in the Southeast.

There are gaps in the level of understanding of potential impacts from wind energy development. As wind development expands, more information is becoming available on the

190 http://www.sewind.org/map 
local community impacts of wind deployment. However, in some cases, this information is available but not readily accessible; in others, the information is not conclusive. Where information does exist, the resources should be made readily available in a form that is understandable for identified stakeholders. Continued and increased engagement at multiple levels will be needed given the expanding nature of the industry.

The Southeastern Wind Coalition provides fact-based information about wind power to various stakeholder groups. For example, wind opponents released information claiming the Amazon wind farm and other proposed wind farms would jeopardize the Navy's Relocatable Over The Horizon Radar (ROTHR) system and some low-level flight training routes. SWERC published a fact sheet on how wind energy and military activities may be developed responsibly and in a compatible manner. SWERC also participated in discussions with stakeholders from the military and state and federal government to educate decision makers on the mitigation process already established to reduce conflict between wind energy and military activities.

The Center for Wind Energy at JMU has been engaged with citizens and officials from Botetourt County, Virginia, since 2014 after county stakeholders initiated efforts to develop a wind ordinance and began discussions with Apex Clean Energy, a Charlottesville-based developer. The Center provided technical guidance as well as wind farm tours, which helped inform the community to employ a local ordinance that was based on a model ordinance developed by the Virginia Department of Environmental Quality despite local misinformation campaigns. This effort led to the first wind project in Virginia to be permitted under the Permit by Rule process currently in place. ${ }^{191}$

The Southeastern Wind Coalition also provided a tour of the Amazon Wind Farm for elected officials in North Carolina. This tour allowed lawmakers to familiarize themselves with wind turbines while learning about the economic development benefits the counties were receiving as a result of the project. North Carolina has been a focus for misinformation campaigns due to the relatively high level of wind-related activity. Tours like these are incredibly informative for decision makers by providing a first-hand experience with a wind farm, something that is uncommon in the region.

Navigating the potential conflicts with existing offshore activities is a challenge and requires significant engagement with many stakeholders. There is extensive interest in offshore wind development across the Southeast, but information is limited based on the lack of offshore development in this and similar regions. Issues from state and federal permitting to differing climatic conditions make it difficult to understand the potential development complications.

The SWERC is working to navigate these issues in Virginia, North Carolina, and South Carolina and has been involved at all levels of offshore wind development to coordinate activities and support across the region. The recent lease of the Kitty Hawk Wind Energy Area in North Carolina by BOEM provided a significant boost in interest in offshore wind in the region. The

${ }^{191}$ http://law.lis.virginia.gov/admincode/title9/agency15/chapter40/ 
SWERC served as a valuable resource to reporters as well as interested citizens and other stakeholders during the lease process.

Since the military is a large economic driver in many parts of the Southeast, potential operational and security impacts caused by wind energy developments can create uncertainty, especially in discussions between base commanders and local government officials. Particularly in North Carolina, the military has been involved in discussions with developers. Through these discussions, project developers, officials from local military bases, and the Department of Defense Wind Energy Clearinghouse have developed mutually agreeable solutions that allow wind development to coexist with military operations. However, military interests have also sparked proposed anti-wind legislative efforts in the state. The SWERC continues to educate stakeholders around the existing policies that protect military base preparedness, including the Clearinghouse. The Southeastern Wind Coalition also prepared a military and wind factsheet ${ }^{192}$ to inform North Carolina state lawmakers.

Some level of utility support will be necessary for wind development to move forward in the Southeast. Many Southeast utilities do not have experience with wind energy, and the unknowns are often extrapolated to "worst-case” perceived risks. That includes all the typical questions that are still unanswered for Southeast development, such as diurnal or daytime wind patterns, ramp rates or power changes, seasonality, demand coincidence, transmission needs, operations and maintenance issues, etc. Issues with offshore wind only expand upon these concerns.

The SWERC is engaged in active discussions with nearly all Southeastern utilities to keep them informed of the latest industry developments and to answer questions. The strong relationships with utilities are one of the SWERC's greatest strengths. The SWERC engages utilities through its Utility Advisory Group, which provides a forum for the utilities to discuss wind energy issues in the Southeast.

Duke Energy hosted an October 2016 Utility Advisory Group meeting in Charlotte, North Carolina, to present on relevant developments for wind in the Southeast. The speakers addressed tall-tower technology, wind resource mapping at greater heights, and economic considerations for wind-generated electricity. These topics are critical to understand for utilities looking to develop wind in the region.

The SWERC hosted an April meeting of the Utility Advisory Group in North Carolina to discuss the history and development of the Amazon Wind Farm U.S East project, the first large utilityscale wind farm in the Southeast. Hearing about the lessons learned from the project and touring the wind farm gave utility representatives the opportunity to increase their understanding of a wind project start to finish.

\subsection{Collaborating Organizations}

RRCs engage diverse stakeholder groups, disseminate targeted technical information about appropriate wind deployment, and provide forums for constructive dialogue. In addition to credible partners such as universities and state energy offices, RRC leaders identify and engage

192 http://www.sewind.org/images/fact_sheets/Wind_And_Military_Factsheet.pdf 
with strong state champions and include these champions in activities whenever possible. Organizations that have collaborated with the SWERC include American Council on Renewable Energy; American Wind Energy Association; Apex Clean Energy; Arkansas Advanced Energy; Arkansas Energy Office; Avangrid Renewables; AWS Truepower; AXYS Technologies; Business Network for Offshore Wind; Cape Fear Community College; Chambers for Innovation and Clean Energy; Chesapeake Climate Action Network; City of North Myrtle Beach; Clean Line Energy; Coastal Carolina University; Consumer Energy Alliance; COWI; Distributed Wind Energy Association; Dominion Power; Duke Energy; Duke University; E4 Carolinas; EDF Renewables; EDP Renewables; Electric Power Research Institute; Energy Foundation; Environment America; Environmental Defense Fund; GE Renewables; Georgia Department of Natural Resources, Coastal Resources Division; Georgia Energy Center of Innovation; Georgia Energy Office; Georgia Public Service Commission; Georgia Tech Strategic Energy Institute; Green Law; Gulf States Renewable Energy Association; K\&L Gates; Kentucky Energy Office; Marsh; Mississippi \& Alabama Sea Grant; Mountain Association for Community Economic Development; National Audubon Society; National Oceanic and Atmospheric Administration; National Wildlife Federation; Natural Resources Defense Council; Nature Conservancy; Navigant; Nicholas Institute; Normandeau Associates; North Carolina Conservation Network; North Carolina Department of Environmental Quality; North Carolina Ports Authority; North Carolina Sea Grant; North Carolina State University; North Carolina Sustainable Energy Association; North Myrtle Beach Chamber of Commerce; Nucor Corporation; Ocean Isle Fishing Center; Parker Poe; Pattern Development; Renewable Energy and Preservation; RES Americas; RES Environmental; Research Triangle Cleantech Cluster; Saertex; Santee Cooper; Savannah River National Laboratory; SCANA Corporation; ScottMadden; Siemens; Sierra Club; South Carolina Clean Energy Business Alliance; South Carolina Coastal Conservation League; South Carolina Sea Grant; South Carolina State Ports Authority; Southeast Energy Efficiency Alliance; Southern Company; Tennessee Department of Environmental Qualitye; Tetra Tech; University of Georgia; University of North Carolina Chapel Hill; University of North Carolina Charlotte (EPIC Center); U.S. Offshore Wind Collaborative; Utility Variable Integration Group; Vaisala; Virginia Conservation Network; Virginia Offshore Wind Coalition; Virginia Renewable Energy Alliance; Virginia Tech; and Wake Forest University.

\subsection{State Updates}

\subsubsection{Alabama}

Alabama has no utility-scale wind installed with no public projects announced. According to the Southeastern Wind Coalition, at the time of publication the state is home to 27 companies and facilities that are involved in the full value chain of the wind energy industry (including headquarters); for current information, see the Wind Industry Supply Chain Database and Map. ${ }^{193}$ In 2016, the industry in the state supported between 100 and 500 direct and indirect jobs (American Wind Energy Association 2017). Recent technology advances have made near- and long-term wind development in the state possible, with economically viable wind development available, primarily in the northeast corner of the state (U.S. Department of Energy 2015e). Development statewide would be possible using 140-m towers and near-future technology options (WINDExchange 2017).

\footnotetext{
193 http://www.sewind.org/map/find-companies
} 
Instead of potentially higher-cost in-state development, Alabama Power has contracts to purchase $404 \mathrm{MW}$ of wind energy from projects located in Kansas and Oklahoma. These contracts, put in place in 2011 and 2012, can provide power for up to 115,000 homes (Alabama Power 2016a).

In September 2015, the Alabama Public Service Commission approved Alabama Power's request for $500 \mathrm{MW}$ of renewable energy (not technology-specific but open to wind energy). This latest request will be directed to customers with renewable energy goals, including the military (Pillion 2015). A year later, Alabama Power issued a request for proposals (RFP) for renewable energy facilities between 5 and $80 \mathrm{MW}$ (Alabama Power 2016b). The RFP resulted in more than 200 proposals. A shortlist was expected to be completed in April 2017. The remaining projects will be subject to additional analysis before Alabama Power selects finalists (Power Engineering 2016).

\subsubsection{Arkansas}

Arkansas does not have in-state wind development. According to the Southeastern Wind Coalition, at the time of publication the state is home to 10 wind manufacturing facilities; for current information, see the Wind Industry Supply Chain Database and Map. ${ }^{194}$ Based on current wind technology, potential economically viable wind terrain extends across Arkansas, with strong potential across the eastern part of the state (WINDExchange 2017). If near-term wind technology is deployed, development across the state is possible, with many areas of resource potential similar to the state's wind-resource-rich western neighbors. However, power utilities are currently taking advantage of their proximity to these low-cost wind development regions to purchase wind instead of developing projects locally.

The Arkansas Electric Cooperative Corporation has three power purchase agreements for wind energy totaling approximately 309 MW from projects in Oklahoma and Kansas. These agreements, which were signed over the past few years, are as follows: a 2012 agreement to purchase $51 \mathrm{MW}$ from the Flat Ridge 2 South Wind Farm in Kansas (Ozarks Electric Cooperative Corporation 2012), a 2013 agreement to purchase 150 MW from the Origin Wind Farm in Oklahoma (Electric Cooperatives of Arkansas 2014), and a 2015 agreement to purchase 108 MW from the Drift Sand Wind Farm in Oklahoma (Electric Cooperatives of Arkansas 2015).

\subsubsection{Florida}

In June 2016, Gulf Power issued a request to the Florida Public Service Commission to add another 94 MW from its existing Kingfisher Wind Farm in Oklahoma. The Public Service Commission approved the initial $178 \mathrm{MW}$ in May 2015. No wind projects have been installed in the state, and there are no projects under construction (American Wind Energy Association 2017). Based on current technology, very limited land-based potential exists for near-term wind development. Several projects have been discussed, primarily in the northern parts of the state. Maps based on near-term future economic potential reveal that much of the state shows promise for expanded economic land-based wind development (WINDExchange 2017). The wind

194 http://www.sewind.org/map/find-companies 
industry currently supports between 1,000 and 2,000 jobs in the state (American Wind Energy Association 2017).

Legislation signed by Governor Rick Scott on June 16, 2017, extends a property tax exemption for renewable energy installations (including wind) on both commercial and residential properties (Advanced Energy Economy 2017).

Florida is headquarters to several major players in the wind energy industry. According to the Southeastern Wind Coalition, at the time of publication the state is home to approximately 64 facilities involved in the wind energy industry's full value chain; for current information, see the Wind Industry Supply Chain Database and Map. ${ }^{195}$ NextEra Energy Resources, headquartered in Juno Beach, is the largest owner of wind power capacity in the United States, and major wind turbine manufacturer Siemens is based in Orlando. Florida has been successful in attracting manufacturing investment for the wind industry. Market leader General Electric has a wind turbine assembly facility in Pensacola, several other wind energy manufacturers have Florida facilities, and Siemens Energy opened a Wind Service Training Center in Orlando in September 2013.

\subsubsection{Georgia}

In 2014, the Georgia Public Service Commission approved Georgia Power's agreement to purchase 151 MW of wind energy from Blue Canyon II and 99 MW from Blue Canyon VI, two wind farms in Oklahoma, beginning in 2016 (Georgia Public Service Commission 2014). During its 2016 integrated resource planning process, Georgia Power initially proposed an addition of $425 \mathrm{MW}$ of utility-scale renewable energy scheduled to achieve commercial operation no later than December 31, 2019 (Georgia Power 2016). The plan was amended and then approved by the Georgia Public Service Commission in July 2016. The approved integrated resource plan calls for an additional 1,200 MW of renewable energy by 2021, with no more than $300 \mathrm{MW}$ to be delivered from wind.

Georgia has limited terrain that would provide economically viable wind development given current technologies, primarily located north and west of Atlanta (WINDExchange 2017). More important, however, Georgia could benefit greatly from near-term, future land-based wind technologies with taller towers and larger rotors (U.S. Department of Energy 2015e). Georgia also has very viable offshore wind potential for near- to mid-term development.

In February 2016, Georgia Power erected a meteorological tower marking the beginning of construction for a small wind demonstration project on the campus of the Skidaway Institute of Oceanography. The plan was to collect data from the meteorological tower and install three small-scale wind turbines (Skidaway Campus Notes 2016). The project experienced technical difficulties and was canceled. Currently, options for installing the two turbines purchased for the project at a different site are being explored. In addition, Georgia Power plans to install a LIDAR system to collect wind data in northern Georgia's mountain region. Georgia Power withdrew its application to pursue the interim policy lease to allow for meteorological measurement activities offshore from Tybee Island.

${ }^{195}$ http://www.sewind.org/map/find-companies 
According to the Southeastern Wind Coalition, Georgia is home to more than 55 companies and facilities that are involved in the full value chain of the wind energy industry; for current information, see the Wind Industry Supply Chain Database and Map. ${ }^{196}$ Georgia Tech's Strategic Energy Institute (which leads the Southeast's RRC and the Georgia Wind Working Group), in partnership with the Georgia Tech Center for Geographic Information Systems and Georgia Department of Natural Resources, debuted the Georgia Coastal and Marine Planner (GCAMP) ${ }^{197}$ to state decision makers and other stakeholders engaged in activities in Georgia's coastal region. A key component of the project is the hypothetical case study of the siting and licensing process to permit a potential offshore wind farm. The GCAMP viewer uses an ArcGIS StoryMap framework to streamline processes through which state and federal agencies can explore how to facilitate energy development in Georgia's coastal waters. The hypothetical offshore wind farm case study allowed stakeholders interested in wind energy to come together in a state without a formal Bureau of Ocean Energy Management wind task force and further shape the policies that may exist in the future. This past year, GCAMP was presented at the American Wind Energy Association Offshore Conference and at several workshops hosted by academic professionals and the Georgia Department of Natural Resources. GCAMP was also featured at the Georgia Environmental Conference in August 2017.

The RRC continued to host workshops in partnership with wind energy affiliates and bi-annual meetings to update wind energy stakeholders about the Georgia Power small wind demo project, GCAMP, and the Georgia Wind Working Group model wind ordinance. The RRC team also relaunched the Georgia Wind Working Group website with updated information after a brief hiatus. Mary Hallisey Hunt and Marcela Moreno of the Strategic Energy Institute also continued to represent wind at a variety of events, including the Just Energy Summit and Clemson-Canada Energy Day.

\subsubsection{Kentucky}

Although Kentucky has no wind farms, the state has a potential capacity of 150,956 MW. According to the Southeastern Wind Coalition, at the time of publication Kentucky is home to 21 companies and facilities that are involved in the full value chain of the wind energy industry; for current information, see the Wind Industry Supply Chain Database and Map. ${ }^{198}$ No development projects have been announced for the state.

Kentucky has good wind resources available across much of the western part of the state and borders states to the north and west that have extensive wind development (WINDExchange 2017). Near-future technology on taller towers has the potential to transform wind activities in the state.

\subsubsection{Louisiana}

In May 2016, Louisiana Wind LLC announced it would develop a 150-MW project in central Louisiana (Texas A\&M Engineering Experiment Station 2016). Project developers have completed land leases, a wind turbine generators assessment, a geotechnical assessment,

\footnotetext{
196 http://www.sewind.org/map/find-companies

197 http://carto.gis.gatech.edu/GCAMP/

198 http://www.sewind.org/map/find-companies
} 
environmental and permitting studies, and a long-term wind measurement. The project is expected to be completed in 2018 (Louisiana Wind 2016).

American Electric Power's Southwestern Electric Power Company has power purchase agreements for 469 MW of wind energy from projects in Texas, Oklahoma, and Kansas (Southwestern Electric Power Company 2016). In 2016, company officials announced an RFP for an additional $200 \mathrm{MW}$ of wind with plans to add 1,200 MW from 2017 to 2037. In May 2016, Entergy Louisiana released an RFP for 200 MW of renewable energy (not technology specific) (Southern Wind Energy Association 2016).

Based on current and near-term future wind technology, a potential economically viable wind terrain expands from along the Mississippi River Valley on the state's eastern border to across the entire state (using taller turbine towers) (WINDExchange 2017). The question of whether to develop local resources or continue to take advantage of close proximity to larger wind markets will be determined by local and state decision makers. Louisiana also has great offshore wind potential.

According to the Southeastern Wind Coalition, at the time of publication Louisiana is home to 32 companies and facilities that are involved in the full value chain of the wind energy industry; for current information, see the Wind Industry Supply Chain Database and Map. ${ }^{199}$ GE Renewables operates a modular blade facility, formerly known as Blade Dynamics, in New Orleans. The facility is primarily focused on research and development. Extensive oil and gas-related industries may also play an important role in future offshore wind development, especially in the Gulf Region.

\subsubsection{Mississippi}

In June 2015, South Mississippi Power Association issued an RFP for $250 \mathrm{MW}$ of wind (SNL 2015). This encouraging development demonstrates that utilities in Mississippi are willing to consider renewables and understand the economic benefits of bringing clean, inexpensive power onto their grids.

Based on current and near-term future wind technology, potential economically developable wind terrain extends from along the Mississippi River Valley on the state's western border to across the entire state (using taller turbine towers) (WINDExchange 2017). The question of whether to develop local resources or take advantage of proximity to larger wind markets in more western states will need to be determined by Mississippi decision makers in the near future.

One transmission project could provide Mississippi with wind energy from Texas. The proposed Southern Cross Transmission project ${ }^{200}$ is a 400 -mile transmission line with a base load capacity of 2,000 MW. If constructed, the project will allow the state to diversify its energy portfolio. A route was submitted in April 2017 and is awaiting Public Utilities Commission approval (Altman 2017).

\footnotetext{
${ }^{199} \mathrm{http}: / /$ www.sewind.org/map/find-companies

200 http://southerncrosstransmission.com/
} 
According to the Southeastern Wind Coalition, Mississippi is home to two companies and facilities that are involved in the full value chain of the wind energy industry; for current information, see the Wind Industry Supply Chain Database and Map. ${ }^{201}$ Although the state has no utility-scale wind installed, the potential for wind development at 110-m hub heights, primarily along the western edge of the state, is significant with a potential of 143.6 terrawatthours per year.

\subsubsection{North Carolina}

North Carolina is home to the recently completed Amazon Wind Farm U.S. East project, the first commercial wind farm project in the state. The initial phase of $208 \mathrm{MW}$ is located in Pasquotank County and Perquimans County in the northeastern part of the state (American Wind Energy Association 2017a).

In 2013, the North Carolina legislature passed a state wind permitting bill that gives the North Carolina Department of Environmental Quality full permitting authority over a project after it has received all separate county approvals (North Carolina Office of the Governor 2013). The Amazon project was permitted prior to the state permitting legislation and was not required to utilize the new process (Murawski 2015). The state permitting bill is yet to be tested, but it appears unclear, duplicative, and leaves a significant amount of discretion in the department's hands about a project's status. For example, the process requires numerous studies but does not identify standards for the studies to meet (King et al. 2016).

A report from the North Carolina Clean Energy Technology Center and North Carolina Sea Grant compares wind energy permitting regulations in North Carolina and six other states. ${ }^{202}$ Lead author James King, a law fellow at the North Carolina Coastal Resources Law, Planning, and Policy Center, compared the policies for Maine, Oklahoma, Oregon, Oklahoma, South Dakota, and Virginia with those for North Carolina. The authors sought to illuminate stakeholders' concerns about a lack of clarity regarding North Carolina's wind permitting rules, notes co-author Ethan Case of the North Carolina Clean Energy Technology Center. This report catalogs wind permitting policies in other states that have successfully attracted out-of-state investors to build wind farms.

North Carolina Wind Working Group stakeholders had suggested that state wind regulations might be deterring investors due to their lack of clarity. This comparative analysis shows numerous policy and regulatory options from other states that could be applied to North Carolina to clarify regulations and make project assessment more efficient. High-level actions to clarify regulations include:

- Providing additional information and guidance for state wind policy features unique to North Carolina

- Providing objective rather than subjective standards for permit approval

- Providing criteria for the evaluation of required information for permits.

Two additional wind projects have been announced this year in North Carolina. Timbermill Wind Farm, an Apex Clean Energy project located near the Amazon project in Chowan and

201 http://www.sewind.org/map/find-companies

202 http://go.ncsu.edu/o7aak7 
Perquimmans Counties, could host up to 105 turbines with a nameplate capacity up to 300 MW. The project could be built on both timberlands as well as private farmland (Apex Clean Energy 2016). The project has been approved for a Certificate of Public Convenience and Necessity by county commissioners in Chowan, and Apex is appealing the decision by Perquimmans to reject the certificate permit. Regardless of the Perquimman's appeal, Apex may choose to build the project solely in Chowan County, which remains an economically viable option. RES Americas is developing the second project, Little Alligator, in Tyrrell County in eastern North Carolina.

North Carolina's 2016 and 2017 legislative sessions passed legislation with implications posing challenges to wind development. House Bill 589, ${ }^{203}$ signed by the Governor on July 27, 2017, instituted an 18-month moratorium for both onshore and offshore wind project permits to determine which areas of the state should be off limits to wind energy development due to potential conflict with military bases. House Bill $470^{204}$ added onerous permitting requirements to the already difficult permitting regime in North Carolina and would effectively work as a ban on wind energy in the state. The industry and clean energy groups, including the SWERC, have been active in efforts to defeat the anti-wind legislation and promote reasonable alternatives. One example of this is House Bill $574^{205}$ that would have given the Department of Military and Veterans Affairs a greater say in permitting while still promoting a site-specific approach to state wide permitting.

Published in September 2017, Duke Energy Carolinas integrated resource plan calls for the addition of $200 \mathrm{MW}$ of wind by 2023 . $^{206}$

According to the Southeastern Wind Coalition, North Carolina is home to approximately 65 companies and facilities that are involved in the full value chain of the wind energy industry; for current information, see the Wind Industry Supply Chain Database and Map. ${ }^{207}$ The state has seen a significant increase in the number of companies serving the wind industry over the past year due to construction in eastern North Carolina. Additional wind projects in the state can help to strengthen and build the local supply chain. The Amazon project will provide an opportunity for communities in the Southeast to see firsthand the benefits of utility-scale wind.

Coastal North Carolina has several kilowatts of distributed wind, some of which are Wind for Schools project turbines. North Carolina participates in the Wind for Schools project through the engagement of Appalachian State University, with the installation of 11 school systems within the state.

Offshore wind in the state has revolved around the Bureau of Ocean Energy Management lease process. North Carolina has three lease areas, the largest of which was leased this year by Avangrid Renewables for $\$ 9.1$ billion (Murawski 2017). The areas at the southern end of the

\footnotetext{
${ }^{203}$ http://www.ncleg.net/gascripts/BillLookUp/BillLookUp.pl?Session=2017\&BillID=h589

$204 \mathrm{http}: / /$ www.ncleg.net/gascripts/BillLookUp/BillLookUp.pl?Session=2017\&BillID=H470

205 http://www.ncleg.net/gascripts/BillLookUp/BillLookUp.pl?Session=2017\&BillID=H574

206

http://www.energy.sc.gov/files/view/2017\%20Duke\%20Energy\%20Carolinas\%20Integrated\%20Resource\%20Plan. pdf

${ }^{207}$ http://www.sewind.org/map/find-companies
} 
state off the coast of Wilmington will be combined with the South Carolina lease process due to proximity with South Carolina's Grand Strand lease area.

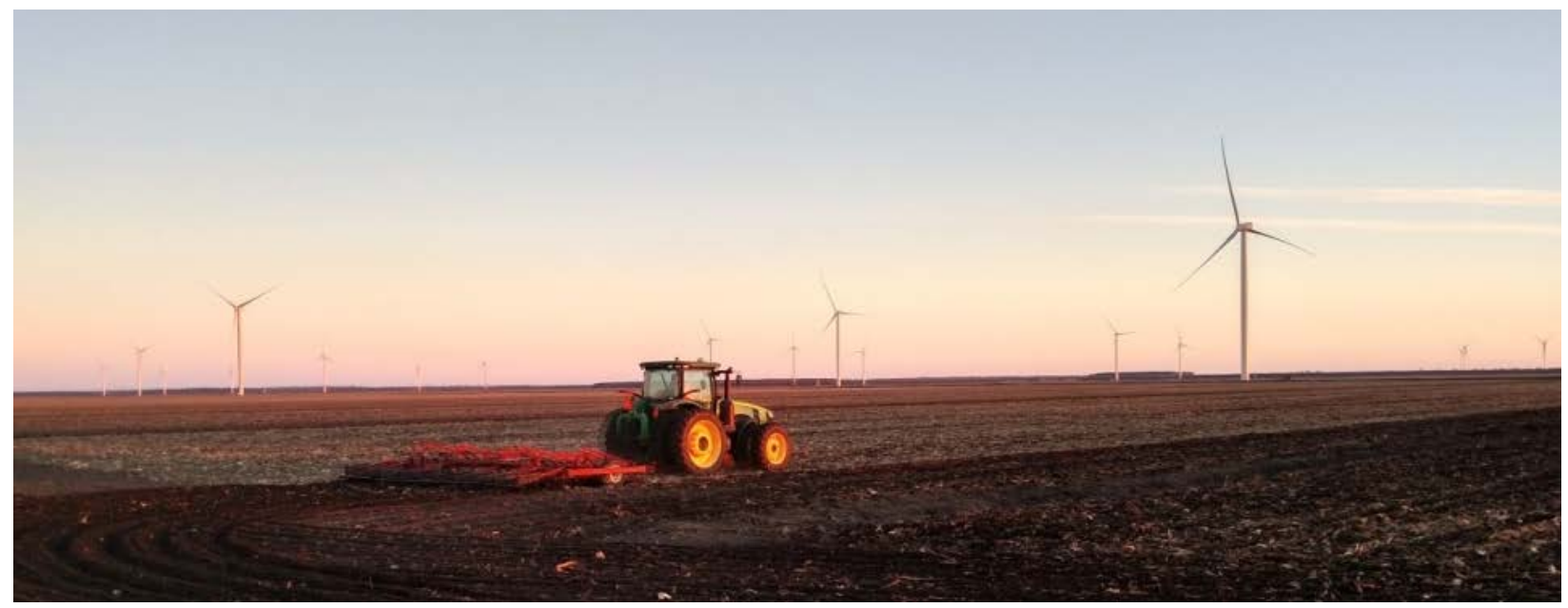

Figure 19. The Southeastern Wind Coalition organized a tour of the Amazon Wind Farm U.S. East, located in Pasquotank and Perquimans Counties in North Carolina. Photo from Avangrid Renewables, NREL 41783

\section{Southeastern Wind Coalition Forms Stakeholder Engagement Groups}

The SEWC leads the Southeast Wind Energy Resource Center, which receives DOE funding support and focuses on providing fact-based, unbiased information about wind energy's costs and benefits to stakeholders and decision makers in an 11-state region. As part of stakeholder engagement efforts, the SEWC formed two groups: the Academic Wind Research Group and the Utility Advisory Group.

The SEWC convened the Academic Wind Research Group to facilitate collaboration between researchers in organizations across the Southeast to advance wind energy. Nearly 40 researchers have joined the group in just a few months.

Recognizing that electric utilities will play a critical role in the growth of the wind industry in the Southeast and that unique challenges and opportunities in the region require a different approach from other regions, the SEWC works closely with utilities to identify options that are attractive to all parties. To accomplish this, the SEWC created a Utility Advisory Group with representation from all major utilities in the region. The advisory group provides input into the SEWC's activities and discusses options for advancing the wind industry that focus on delivering net benefits to utility shareholders, citizens and ratepayers, and the wind industry. The group provides a forum for utility participants to discuss approaches to land-based and offshore wind energy, share lessons learned, and explore opportunities for multi-utility collaboration.

\subsubsection{South Carolina}

South Carolina has a few kilowatts of wind power capacity installed as a result of Wind for Schools projects deployed in North Carolina, as well as ongoing efforts for offshore wind in the state. The state has four Wind Energy Areas in the Bureau of Ocean Energy Management's lease process and is in the process of determining interest from developers. ${ }^{208}$ In 2014, the South Carolina General Assembly passed a resolution that acknowledges the state's wind

${ }^{208}$ http://www.boem.gov/South-Carolina/ 
manufacturing assets, offshore wind resource potential, supportive local governments, and Clemson University's large-scale wind turbine drivetrain testing facility in Charleston. Several local governments in the state (Charleston, North Charleston, and North Myrtle Beach) have also expressed support for wind energy. In 2017, legislation was introduced that would build on this support. H.4304 ${ }^{209}$ would allow for the South Carolina Public Service Commission to create a path for utilities to invest in an offshore wind demonstration project up to $75 \mathrm{MW}$, as well as rate recovery.

As with many states in the Southeast, South Carolina has limited terrain (primarily located in the center of the state) that would allow economically viable wind development given current technologies (WINDExchange 2017). More important, however, South Carolina could benefit greatly from near-term future land-based wind technologies with taller towers and larger rotors (U.S. Department of Energy 2015e). South Carolina, with its abundant coastline and shallow waters, also has great potential for near- to mid-term offshore wind development.

Published in September 2017, Duke Energy Carolinas IRP calls for the addition of plans 200 MW of wind by $2023 .^{210}$

The SWERC worked with the South Carolina Coastal Conservation League to provide an economic development fact sheet specific to South Carolina for use in discussions about the benefits of land-based wind energy to the state. ${ }^{211}$ South Carolina has leveraged its manufacturing expertise to gain numerous suppliers to the wind industry. According to the Southeastern Wind Coalition, South Carolina is home to approximately 48 companies and facilities that are involved in the full value chain of the wind energy industry; for current information, see the Wind Industry Supply Chain Database and Map. ${ }^{212}$

\subsubsection{Tennessee}

Tennessee is home to the Southeast's first commercial wind farm, the 29-MW Buffalo Mountain project completed in 2004. According to the Southeastern Wind Coalition, Tennessee is home to approximately 29 companies and facilities that are involved in the full value chain of the wind energy industry; for current information, see the Wind Industry Supply Chain Database and Map. ${ }^{213}$ The Tennessee Valley Authority has nine contracts with nine wind farms for more than $1,500 \mathrm{MW}$ of wind energy. ${ }^{214}$

Local development continues to be an option for Tennessee as well. Based on current wind technology, several regions in the west and central parts of the state have resources to support economic wind development (WINDExchange 2017). Near-future technology opens up

\footnotetext{
209 http://www.scstatehouse.gov/sess122_2017-2018/bills/4304.htm

210

http://www.energy.sc.gov/files/view/2017\%20Duke\%20Energy\%20Carolinas\%20Integrated\%20Resource\%20Plan. pdf

${ }^{211}$ http://www.sewind.org/images/fact_sheets/SC_Wind_Economic_Development.pdf

212 http://www.sewind.org/map/find-companies

213 http://www.sewind.org/map/find-companies

214 See contract details at https://www.tva.gov/Energy/Valley-Renewable-Energy/Wind-Energy-Contracts
} 
development potential across the western part of the state, which would sidestep many of the local concerns around ridgeline development.

However, legislation passed in 2017 may delay in-state generation. Senate Bill $1336^{215}$ institutes a 1-year moratorium on any new wind permits and convenes a committee of six members of the State House and Senate to examine best practices for permitting wind. The 71-MW Crab Orchard project announced by Apex Clean Energy in January 2016 was suspended due to the 1year moratorium (Humphrey 2017). The project would have been the state's largest and was expected to be located in Cumberland County, not far from the existing Buffalo Mountain project.

\subsubsection{Virginia}

Virginia’s proposed land-based wind projects are making progress, notably Apex Clean Energy's Rocky Forge Wind Energy Project in Botetourt County (Hammack 2016). Although a utility to purchase the power generated from the proposed 80-MW project must be found, work on access roads is expected to begin in late 2017, with turbine construction commencing the following summer (Hammack 2017). As the first wind project to go through Virginia's permit by rule process for wind farms between $5 \mathrm{MW}$ and $150 \mathrm{MW}$. The recent expansion of the permit by rule to include projects up to $150 \mathrm{MW}$ (increased from $100 \mathrm{MW}$ ) will also allow more projects to qualify for these permits in the state. ${ }^{216}$

An additional effort that could expand wind energy in Virginia is Executive Order 57. Signed by Virginia Governor Terry McAuliffe on June 28, 2016, Executive Order 57 directs the Secretary of Natural Resources "to convene a Work Group, chaired by the Secretary, to study and recommend methods to reduce carbon emissions from electric power generations facilities.”217 The Southeastern Wind Coalition attended a Work Group meeting and presented information on the benefits and considerations of wind energy for Virginia.

Published in May 2017, Appalachian Power's integrated resource plan ${ }^{218}$ calls for the addition of 1,350 MW of wind energy by 2031.

The establishment of new regulations regarding renewable energy produced at agricultural facilities also occurred in 2017. The Small Agricultural Generators Program ${ }^{219}$ defines the ways in which these installations sell output to utilities and defines eligible projects at a capacity limit of $1.5 \mathrm{MW}$.

Apex is developing two more projects in Virginia. The Pinewood Wind project in Pulaski County would be a 200-MW project with an expected completion date at the end of 2020. Farther west, Mill Creek Wind in Wise County is a 120-MW project on the border of Virginia and Tennessee. In addition to these projects, EDP Renewables continues to gather information

215 http://www.capitol.tn.gov/Bills/110/Bill/SB1336.pdf

216 https://lis.virginia.gov/cgi-bin/legp604.exe?171+sum+SB1395

217 https://naturalresources.virginia.gov/initiatives/eo-57

218 https://www.appalachianpower.com/info/news/viewRelease.aspx?releaseID=2221

219 https://lis.virginia.gov/cgi-bin/legp604.exe?171+sum+HB2303 
and engage local stakeholders around its newly announced project in Carroll County. Despite the increased activity around land-based wind projects, much of the focus remains on solar energy.

Virginia Electric and Power Company was awarded an offshore wind energy lease for the Virginia Wind Energy Area (Bureau of Ocean Energy Management 2016), and Virginia’s Department of Mines, Minerals and Energy was awarded a research lease for the two-turbine Virginia Offshore Wind Technology Advancement Project. This project, led by Dominion Virginia Power, would deploy two direct-drive Alstom wind turbines 26 miles off the coast of Virginia Beach. The project, designed to reduce costs and uncertainty for a future large-scale project, is undertaking a review process to find a path forward for the project after it failed to meet established milestones and therefore lost the ability to qualify for $\$ 40$ million in additional funding from DOE (Dominion Power 2016). A path forward was announced in July 2017, when Dominion revealed a new partnership with Dong Energy that will include the installation of two 6-MW turbines by 2020 (Zullo 2017).

Potential ridgetop development in Virginia mirrors development that has taken place in West Virginia, clearly demonstrating the potential development opportunities in the western part of the state. When considering near-future technology, the taller towers and advanced wind turbines could open up the eastern part of the state to more conventional land-based wind development.

According to the Southeastern Wind Coalition, Virginia is home to approximately 37 companies and facilities that are involved in the full value chain of the wind energy industry; for current information, see the Wind Industry Supply Chain Database and Map. ${ }^{20}$

JMU and Virginia Polytechnic Institute and State University (Virginia Tech) offer wind education programs in the state. JMU participated in the inaugural DOE Collegiate Wind Competition in 2014 and, as stated previously, DOE's Wind for Schools program, which is discussed in greater detail in Section 7.3: Workforce Development. Virginia Tech is also an organizing member of the North American Wind Energy Academy. Both universities have been selected to participate in the 2018 Collegiate Wind Competition.

This year's KidWind Challenge ${ }^{221}$ season was a success with three Regional Challenges held at the Chesapeake Bay Foundation’s Brock Environmental Center, George Mason University’s School of Engineering, and Dabney S. Lancaster Community College. With more than 30 teams competing, Virginia sent five middle school and high school teams to the National KidWind Challenge in Anaheim, California, during the AWEA WINDPOWER Conference. All the Virginia teams received an award at the national competition. The Learning Barn Off the Grid team from Botetourt County won first place in the high school division and holds the new record for turbine energy output. In the middle school division, the teams from Virginia placed first, second, and third, and the other Virginia team won the Siting Instant Challenge.

Virginia has also seen a considerable amount of distributed wind activity. In 2015, with support from the Virginia Department of Mines, Minerals and Energy, the Center for Wind Energy at JMU initiated a pilot program to identify organizations that reside on properties and in localities that would be suitable for distributed wind (and solar) deployment. Between 2015 and 2017, the

${ }^{220}$ http://www.sewind.org/map/find-companies

221 https://www.kidwindchallenge.org/ 
Center conducted analyses on numerous properties and worked with landowners to specify details of prospective distributed wind systems and to develop applications for Rural Educational for America Program funding for those landowners who would be eligible. The Center was recently awarded a Rural Energy Development Assistance grant along with additional matching funds committed by the Department of Mines, Minerals and Energy that will enable to the Center to increase its efforts to further advance distributed wind in Virginia. 


\section{Updates for States Outside of RRC Regions}

The states not supported by an RRC are California, Delaware, Kansas, Maryland, Nebraska, Oklahoma, Texas, and West Virginia. ${ }^{222}$ Stakeholders can consult U.S. Department of Energy's (DOE's) interactive Wind Vision Study Scenario Viewer ${ }^{223}$ to learn more about state-specific impacts from wind development.

\subsection{State Updates}

The WINDExchange team based at the National Renewable Energy Laboratory (NREL) researched the current state of wind energy in states not directly supported by a Regional Resource Center (RRC) and compiled the following summaries.

\subsubsection{California}

As of December 2017, California's installed wind capacity was 5,609 megawatts (MW) (American Wind Energy Association 2018), including $66 \mathrm{MW}$ of distributed wind installed from 2003 to 2016. This amount of development equates to a \$12.5 billion capital investment. California generated 13,698 gigawatt-hours from wind in 2016, equivalent to approximately $6.8 \%$ of the state's gross system power.

In May 2017, proposed legislation was advanced to the Assembly after the state senate approved increasing the state's renewables portfolio standard (RPS) to 100\% renewable energy by 2045. SB-100 would have also modified the state's current goal of 50\% renewable energy by 2030 to $50 \%$ by 2026. The bill failed to advance the 2017 legislative session but is expected to be brought up again next year. The state's original RPS called for $20 \%$ renewables by 2020 . It was increased to 33\% in 2011 (California Energy Commission 2016a). Eleven communities in California have committed to a 100\% renewable energy transition. Del Mar, Menlo Park, Monterey, Palo Alto, San Diego, San Francisco, San Jose, Santa Barbara, Solana Beach, South Lake Tahoe, and Truckee have goals of achieving $100 \%$ of their electricity from renewable sources.

Although the state has strong offshore wind potential, many challenges must be overcome prior to any project development. These challenges include establishing an environmental baseline for potential project locations to understand impacts on avian and marine wildlife. The current high cost of offshore wind compared to land-based wind and solar has also been a challenge, although costs are expected to decline in the next decade. California's deep waters will require floating platforms for offshore wind projects, and these platforms are still in the prototype stage (van Dam 2014).

With the large amount of solar power deployed in California, utilities are looking for a power source that will quickly ramp up as the sun goes down. According to NREL modeling, offshore wind seems to complement wind well during this time, with wind speeds increasing as solar ramps down. NREL researchers have also devised two offshore wind development scenarios with state gross domestic product impacts of \$39.7 billion in Scenario A for construction or

\footnotetext{
222 The WINDExchange team based at NREL provides technical support for states not directly supported by an RRC.

${ }^{223}$ http://en.openei.org/apps/wv_viewer/
} 
$\$ 16.2$ billion in Scenario B; and $\$ 7.9$ billion in Scenario A for the operations phases or $\$ 3.5$ billion in Scenario B (Speer et al. 2016).

Trident Winds proposed California's first offshore wind project in early 2016. If the 800-MW project were to move forward, it would consist of 100 floating turbines in Morro Bay and would contribute to the state meeting its new RPS goals (Lillian 2016).

Two transmission projects have played an integral role in the state meeting its RPS goal. The first project, the Tehachapi Renewable Transmission Project (Edison International), is a 173-mile project that was completed in December 2016 and can transmit 4,500 MW of wind energy to the state. The second project, the Sunrise Powerlink, connects wind and solar resources in the southern-most part of California to the state grid. A proposed project, the TransWest Express transmission line, would have the ability to connect up to 3,000 MW of Wyoming wind energy to the Desert Southwest region (California, Nevada, and Arizona). A Record of Decision has been issued for the project by the Bureau of Land Management (December 2016), the Western Area Power Administration (January 2017), and the U.S. Forest Service (May 2017).

Siting challenges in California include regulatory processes designed to ensure that projects will not cause undue harm to wildlife, including raptors, desert tortoises, and other species. The U.S. Bureau of Land Management adopted Phase I of the Desert Renewable Energy Conservation Plan in September 2016 to help address wildlife impacts by closing off millions of acres to development of clean energy projects (Roth 2015).) However, in addition to the 388,000 acres of Development Focus Areas, ${ }^{24} 40,000$ acres of Variance Process Lands and 419,000 acres of General Public Lands are still available for renewable energy development. As defined in the Plan, Development Focus Areas are lands where renewable projects (including wind) are allowed and could be streamlined for development. Variance Process Lands provide potential opportunities for the development of renewable projects, which could be approved using a variance process without the need for an amendment to the Plan. Allowable projects must be compatible with the Bureau of Land Management Conservation and Management Actions that are in place for these lands. Additionally, renewable development may be approved on General Public Lands (lands that are not included in the permit streamlining). Phase II of the plan will be implemented by separate county government actions in the region and may result in limitations on the level of renewable energy development (including wind) that could occur on private lands (U.S. Bureau of Land Management 2016a).

California ranks fourth among the top five states for wind energy generation (the other top five states are Texas, Iowa, Oklahoma, and Illinois) (American Wind Energy Association 2017). California is home to between 3,000 and 4,000 direct and indirect jobs related to the wind energy industry (American Wind Energy Association 2017), and the state ranked fifth in 2016 in terms of distributed wind capacity (U.S. Department of Energy 2017a).

Two California schools have participated in the DOE Collegiate Wind Competition. California State University Maritime Academy hosted an undergraduate team for the Collegiate Wind Competitions in 2014 and 2016, as well as the 2015 and 2017 Collegiate Wind Competition

\footnotetext{
${ }^{224}$ Development Focus Areas are areas with high renewable energy potential and transmission access where
} sensitive ecological and cultural resources impacts can be avoided, minimized, or mitigated. 
Technical Challenges. California State University Chico hosted teams for the 2016 Competition and 2017 Technical Challenge. Both universities were selected to participate in Collegiate Wind Competition 2018. Several universities in the state (such as the University of California, Davis and University of California, Berkeley) have been at the forefront of wind energy research.

Visit the WINDExchange website for information about school wind projects and educational programs in California and other states.

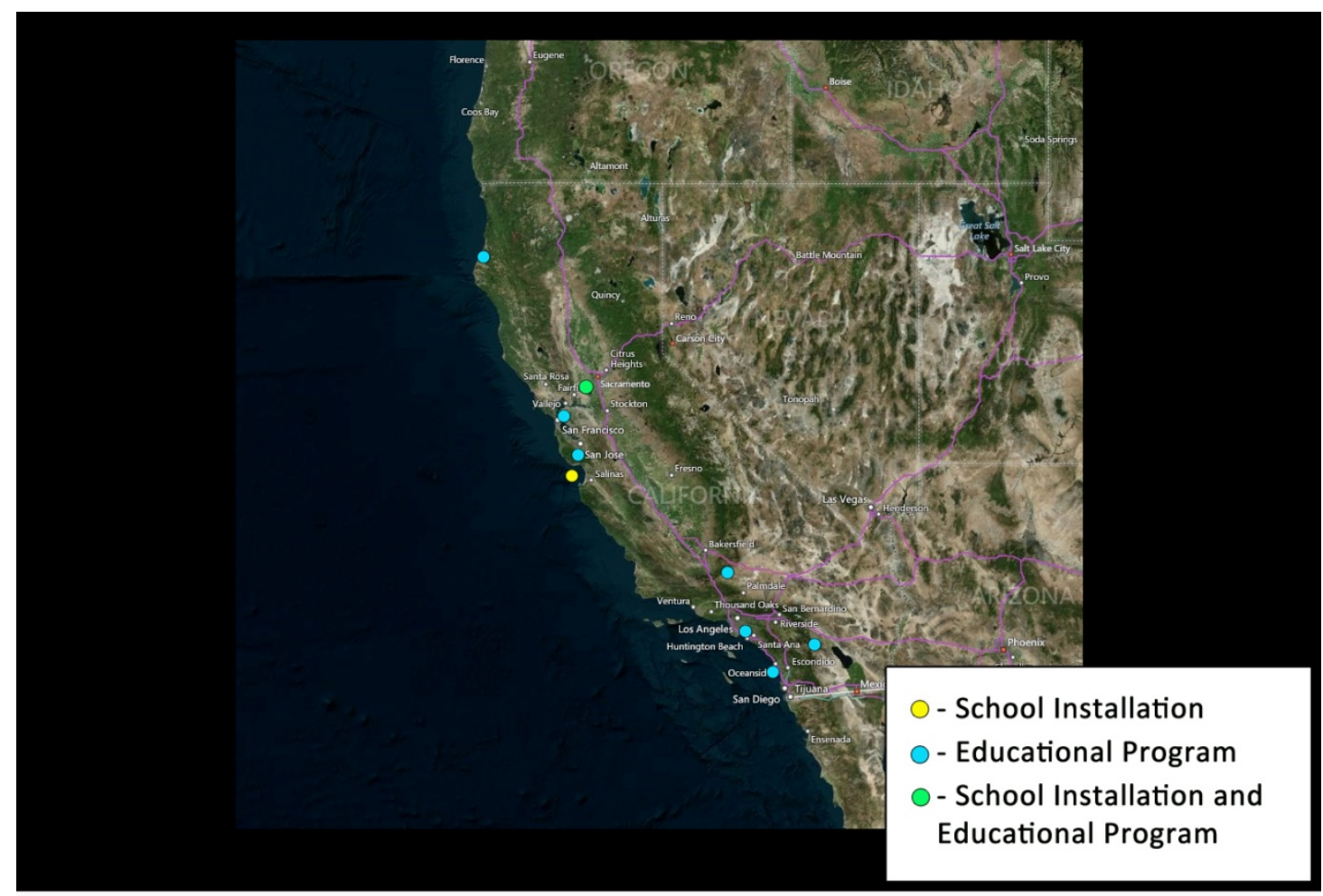

\section{California}

Figure 20. Map of school wind turbine projects, educational programs, and locations with both wind turbines and educational programs in California

NREL researchers compiled the California wind energy manufacturing data in Table 30 as part of DOE’s annual wind market report effort (U.S. Department of Energy 2017c).

Table 30. California Wind-Related Manufacturing Overview

\begin{tabular}{lll}
\hline Name & City & Component \\
\hline PowerWorks & Tracy & Distributed wind turbines \\
\hline
\end{tabular}

\subsubsection{Delaware}

As of December 2017, Delaware has 2 MW of wind capacity installed (American Wind Energy Association 2018) (a distributed wind project at the University of Delaware's Lewes campus), representing \$5 million in capital investment. The state has no wind projects under construction 
and no wind energy manufacturing facilities (American Wind Energy Association 2017). Offshore wind has had difficulty gaining traction in the state. In late 2011, development ceased on the proposed 200-MW Mid-Atlantic Wind Park (Maryland Coast Dispatch 2011). Although no additional offshore wind projects have been proposed since 2011, on August 28, 2017, Governor Carney signed Executive Order $13^{225}$ establishing the Offshore Wind Working Group to study and report on how Delaware can participate in offshore wind development.

Delaware has implemented an aggressive RPS that requires all retail electricity suppliers to purchase $25 \%$ of the electricity sold in the state from renewable sources by the end of the 2026 state fiscal year. However, the RPS requirements leading to wind energy projects are effectively reduced by a determination that provides a two-times renewable energy credit multiplier for the energy output of certain natural gas-powered fuel cells (State of Delaware Public Service Commission 2011).

One local utility, Delmarva Power and Light Company, issued a request for proposals for wind renewable energy credits on February 17, 2017. The request is for bids from one or more wind energy facilities for up to 40 MW beginning in 2017-2018 for a term of 10 to 15 years. The credits purchase will help Delmarva Power meet RPS requirements (Delmarva Power and Light Company 2017).

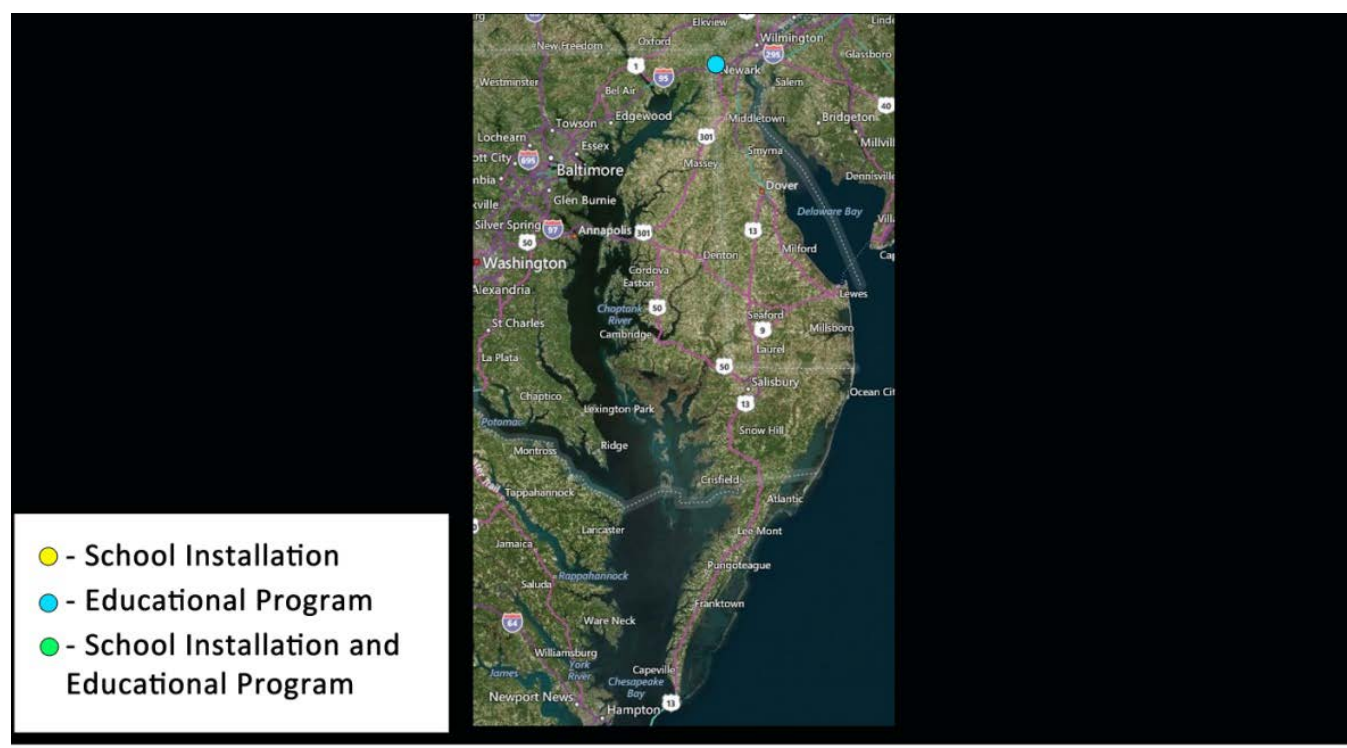

\section{Delaware}

Figure 21. Map of sole educational program location in Delaware

The University of Delaware has developed extensive capabilities in offshore wind technology and research involving the social acceptance of land-based and offshore wind technologies. Visit

${ }^{225}$ https://governor.delaware.gov/executive-orders/eo13/ 
the WINDExchange website for information about school wind projects and educational programs in Delaware and other states. ${ }^{226}$

\subsubsection{Kansas}

As of December 2017, Kansas had 5,110 MW of installed wind capacity (American Wind Energy Association 2018), including 7.4 MW of distributed wind (U.S. Department of Energy 2017a). In 2016, wind provided $29.6 \%$ of all in-state electricity production. This amount of development equates to an $\$ 8.4$ billion capital investment (American Wind Energy Association 2017).

Wind energy provides further economic development in the state through wind turbine manufacturing. Siemens has operated a \$50 million nacelle assembly facility in Hutchinson since 2010. A merger with Gamesa was announced in June 2016 and finalized in April 2017, leading to the creation of Siemens Gamesa Renewable Energy. A layoff of 140 workers was announced in August 2017, attributed to a lack of orders for nacelles in 2018 (Green 2017).

Kansas is among a growing number of states to take advantage of the private sector owning, developing, or purchasing directly from wind projects. In 2016, Microsoft and Google announced separate energy purchases from new wind projects in the state (Enel Green Power 2017, Microsoft 2016).

In Barber County, revenue from wind energy development has softened the blow to the local economy from lost oil-related revenue. On an annual basis, the county receives nearly $\$ 500,000$ in payments in lieu of taxes for turbines associated with Phase I and II of the Flat Ridge Wind Project. The county also receives \$2,000 per megawatt from the Flat Ridge I and \$3,000 per megawatt from the Flat Ridge II (Rose 2016) wind projects.

The state enacted an RPS in May 2009 that requires certain utilities to generate or purchase 20\% of their electricity from renewable resources by 2020. The RPS was repealed in May 2015 and replaced with a voluntary goal of 20\% electricity from renewable resources by 2020 (American Wind Energy Association 2017). One town in Kansas established its own renewable energy goals that stretch beyond the state RPS. Greensburg established a goal of 100\% renewable energy in 2007 and met the goal in 2013 primarily through energy generated by the 12.5-MW Greensburg Wind Farm (Sierra Club 2016).

Several market barriers inhibit wind development in Kansas. According to a survey conducted by Kansas State University in 2010, environmental concerns rated the highest. People are concerned about potential development in the Flint Hills; the proximity of wind turbines to the great wetlands of Cheyenne Bottoms and Quivera Wildlife Refuge, a popular stopover point for waterfowl and cranes; and the impact on prairie chicken species that are under threat in Kansas. Other human-use concerns about developing wind power in Kansas include health impacts and property rights.

An additional market barrier to wind development in the state is a lack of transmission to deliver clean energy from wind-rich areas to the demand. In December 2016, the 60-mile Elm Creek to

${ }^{226}$ https://windexchange.energy.gov/education-workforce 
Summit Project went online, providing increased reliability and new wind transmission capacity between Salina and Concordia. The southern half of the project is owned and operated by Westar Energy. ITC Great Plains and Mid-Kansas Electric Company co-own the northern half of the project (ITC 2017). Additionally, the proposed Grain Belt Express Clean Line will impact the ability to transmit Kansas wind energy outside of the state. If approved, the 780-mile project will deliver 4,000 MW of wind energy from the western portion of the state to Missouri, Indiana, Illinois, and neighboring states (Clean Line Energy Partners 2017). In July 2016, Missouri's Public Service Commission denied the project's application based on procedural grounds (Public Service Commission of the State of Missouri 2016). Project developers refiled the application in late August 2016. A Public Service Commission decision is expected to take up to a year (Shelbyville Daily Union 2016).

Kansas participates in the Wind for Schools project through the engagement of Kansas State University, with 26 school systems installed. The state's Wind Application Center is working to help these systems collect data and send information to the OpenEI turbine database. ${ }^{227}$

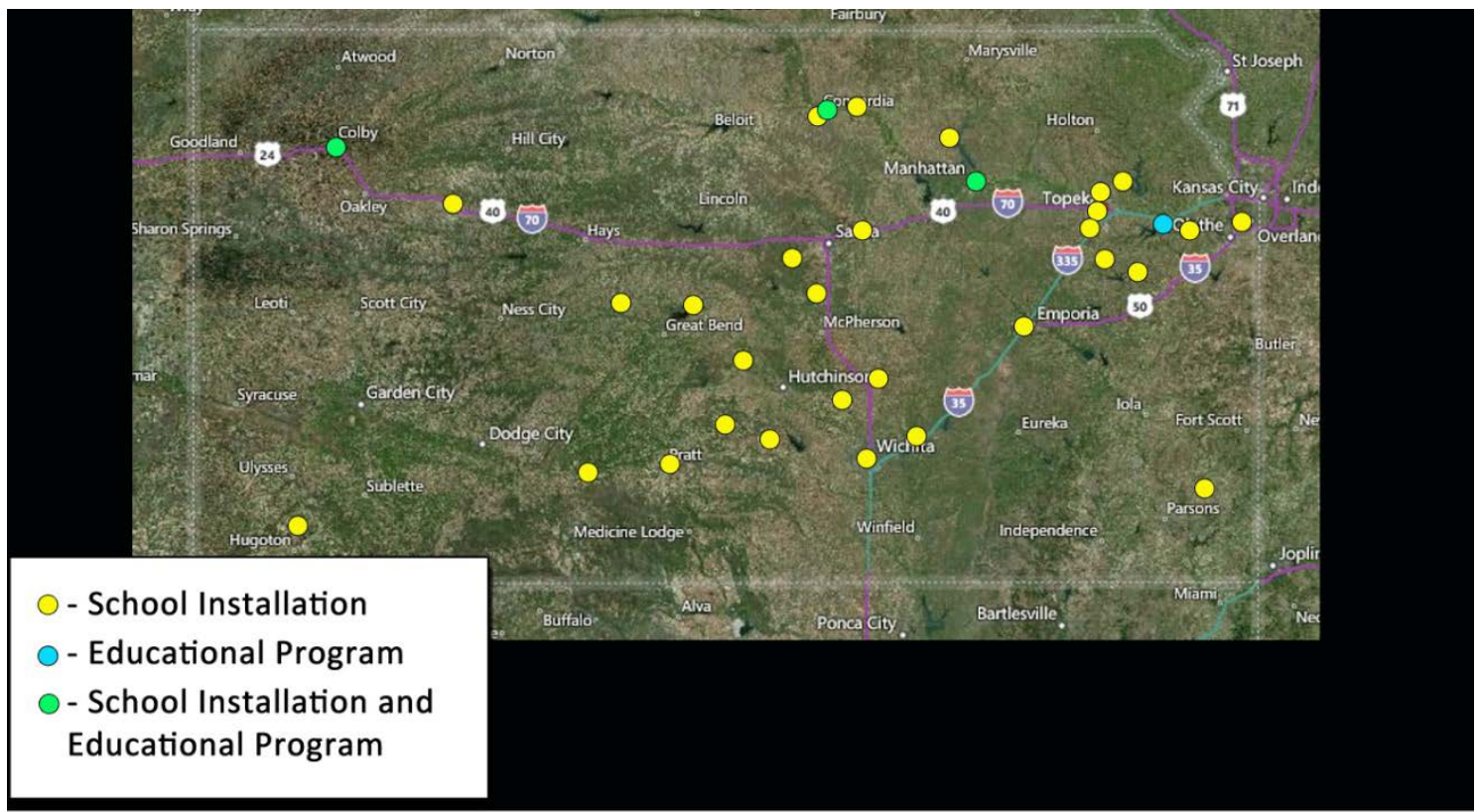

\section{Kansas}

Figure 22. Map of school wind turbine projects, educational programs, and locations with both wind turbines and educational programs in Kansas

Kansas State University hosted an undergraduate team for DOE’s 2014 and 2016 Collegiate Wind Competitions, as well as the 2015 and 2017 Collegiate Wind Competition Technical Challenge. The University of Kansas also participated in the 2014 Collegiate Wind Competition and the 2015 Collegiate Wind Competition Technical Challenge. Kansas State University has been selected to participate in the 2018 Collegiate Wind Competition.

${ }^{227}$ http://en.openei.org/wiki/Wind_for_Schools_Portal 


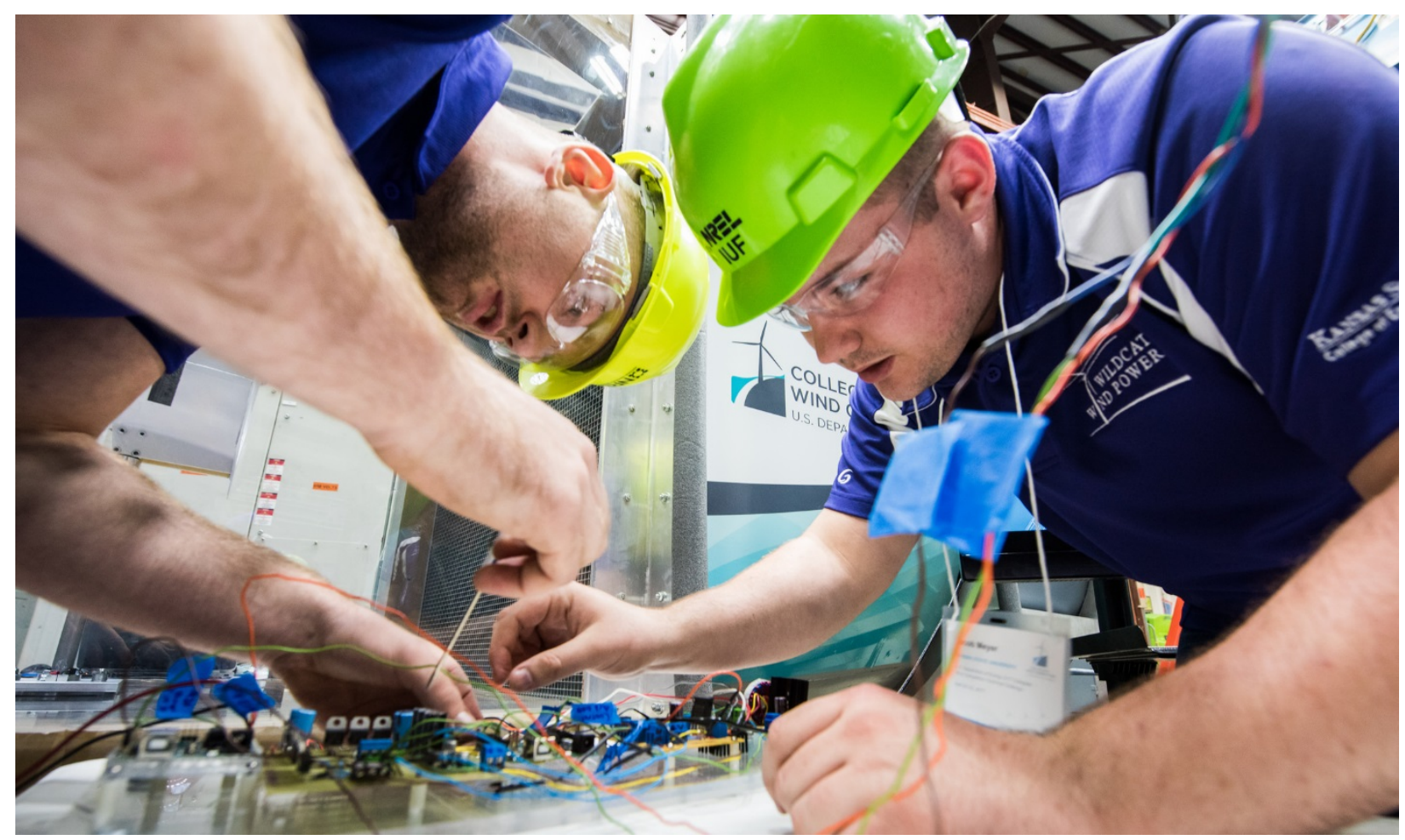

Figure 23. Kansas State University students connect the electrical components of their wind turbine before wind tunnel testing. The team took home second place overall in the 2017 Collegiate Wind Competition. Photo by Dennis Schroeder, NREL

Visit the WINDExchange website for information about school wind projects and educational programs in Kansas and other states. ${ }^{228}$

NREL researchers compiled the following Kansas wind energy manufacturing data as part of DOE’s annual wind market report effort (U.S. Department of Energy 2017c).

Table 31. Kansas Wind-Related Manufacturing Overview

\begin{tabular}{lll}
\hline Name & City & Component \\
\hline J.R. Custom Metal Products & Wichita & Machined components \\
\hline Jupiter Group & Junction City & Nacelle covers and spinners \\
Siemens & Hutchinson & Turbines \\
\hline
\end{tabular}

\subsubsection{Maryland}

As of December 2017, Maryland had 191 MW of installed wind (American Wind Energy Association 2018), including .4 MW of distributed wind (U.S. Department of Energy 2017a). In 2016, wind provided $1.4 \%$ of all in-state electricity production. This amount of development equates to a \$396 million capital investment (American Wind Energy Association 2017). In

${ }^{228}$ https://windexchange.energy.gov/education-workforce 
2017, the state installed one project: the 750-kW turbine at the Crisfield Wastewater Treatment Plant offsets energy used at the facility (Nunez 2017).

An attempt to increase the state's RPS to $25 \%$ by 2020 was approved by the state House and Senate but was vetoed by the governor in May 2016 (Walton 2016). In February 2017, state lawmakers superseded the governor's veto, increasing the state's renewable portfolio standard from $20 \%$ by 2022 to $25 \%$ by 2020 . One city in Maryland established its own renewable energy goals that stretch beyond the state RPS (Sierra Club 2017). Columbia, home to approximately 100,000 people, reached this goal in September 2015; approximately 75\% of this goal was met by renewable energy credits associated with wind energy (SunEdison 2015).

With an aggressive RPS, Maryland has many additional opportunities for land-based and offshore projects. In May 2017, the Maryland Public Service Commission advanced two offshore wind projects by awarding Offshore Renewable Energy Credits at a levelized price of $\$ 131.93$ per MWh over a 20-year period. The U.S. Wind and Skipjack developments will have a combined 368 MW of capacity (Maryland Public Service Commission 2017a).

Land-based wind development has recently faced increasing concerns with radar, wildlife, aesthetic, and property value impacts (Wheeler 2015). For example, in June 2017, the Maryland Public Service Commission confirmed a Public Utility Law Judge's earlier ruling that denied Dan's Mountain Wind Force, developers of a proposed 17-turbine project, an application for a certificate of public convenience and necessity permit. Within the order affirming the decision, the Maryland Public Service Commission cited aesthetic concerns and potential impacts from noise and shadow flicker as part of the reason for the permit denial (Maryland Public Service Commission 2017b).

Although Maryland does not have many higher education wind energy programs, the University of Maryland participated in DOE’s 2016 Collegiate Wind Competition and 2017 Collegiate Wind Competition Technical Challenge. Visit the WINDExchange website for information about school wind projects and educational programs in Maryland and other states. ${ }^{229}$

${ }^{229}$ https://windexchange.energy.gov/education-workforce 


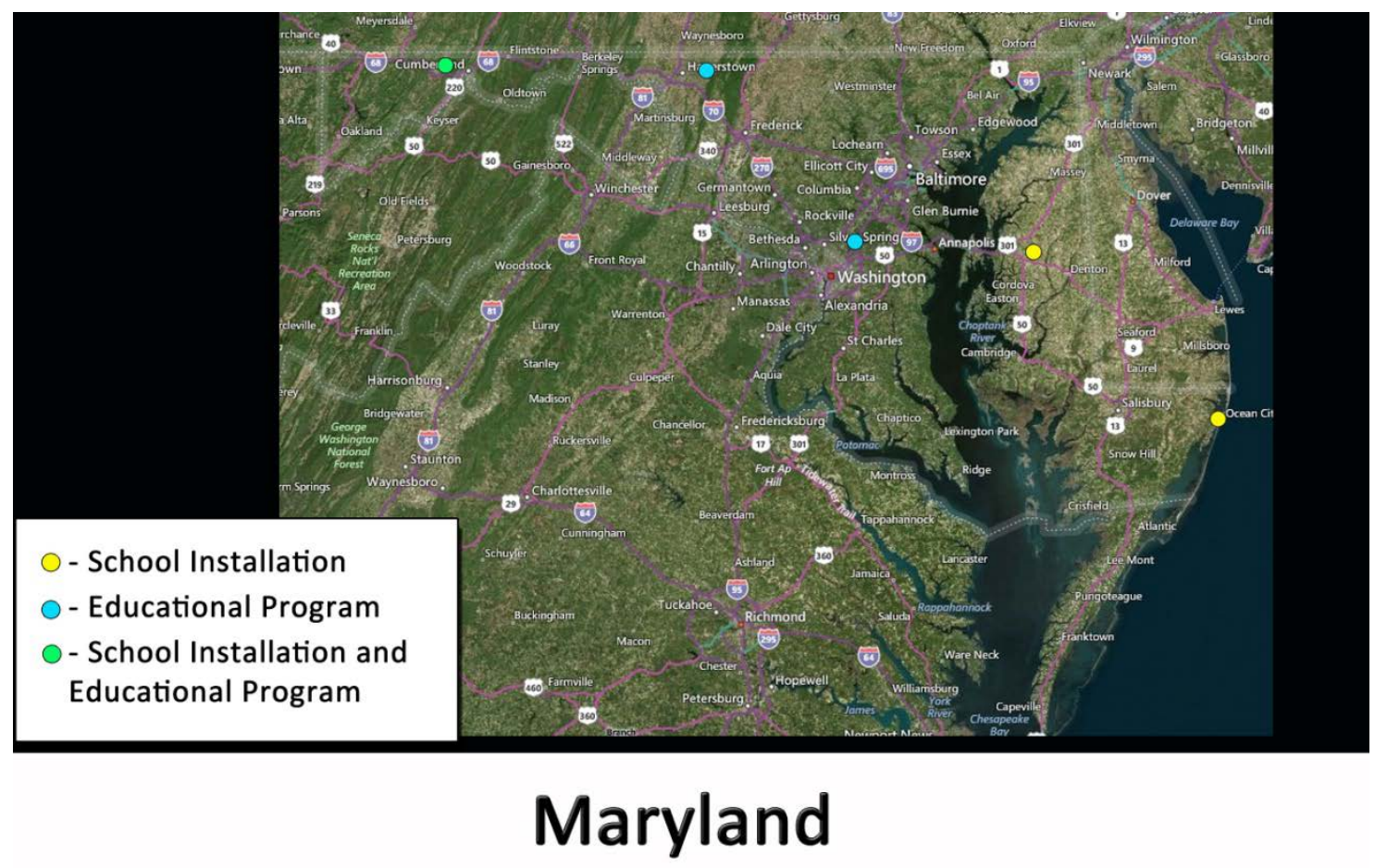

Figure 24. Map of school wind turbine projects, educational programs, and locations with both wind turbines and educational programs in Maryland

NREL researchers compiled the following Maryland wind energy manufacturing data as part of DOE’s annual wind market report effort (U.S. Department of Energy 2017c).

Table 32. Maryland Wind-Related Manufacturing Overview

\begin{tabular}{lll}
\hline Name & City & Component \\
\hline LAl International & Westminster & Bearing cages \\
\hline
\end{tabular}

\subsubsection{Nebraska}

Nebraska is the latest state to eclipse the 1,000-MW mark for installed wind capacity. As of December 2017, Nebraska had 1,426 MW of installed wind capacity (American Wind Energy Association 2018), including 15.1 MW of distributed wind that was installed between 2003 and 2016 (U.S. Department of Energy 2017a). In 2016, wind provided 10.1\% of all in-state electricity production. This amount of development equates to a $\$ 2.4$ billion capital investment. At the end of December 2017, the state had 702 MW of wind energy under construction (American Wind Energy Association 2018).

Additional commitments by local utilities are beginning to shape Nebraska's energy future. Nebraska Public Power District is working to achieve its goal of $10 \%$ energy from renewable resources by 2020. In 2015, the state announced the final route for its $\$ 361$ million R-Project. ${ }^{230}$ The 220-plus-mile project will provide new transmission capacity to address future renewable

230 http://www.nppd.com/rproject/ 
generation (Nebraska Public Power District 2015). The beginning of construction is yet to be determined.

Omaha Public Power District brought new transmission online in 2016. The Midwest Transmission Project, a 180-mile transmission line from Nebraska City to Sibley, Missouri, was designed to advance renewable energy development and increase system reliability. Built in partnership with Kansas City Power and Light, the project was completed in December 2016 (King-Homan and Roger 2016). The Omaha Public Power District also confirmed its plan to have more than $40 \%$ of future retail generation provided by renewable resources by late 2019 (Omaha Public Power District 2017).

The Nebraska Farmers Union and the American Corn Growers Foundation's Wealth from the Wind program performed public outreach to communities and reported that customers and landowners in Nebraska are generally supportive of wind energy. In addition, since 2008, volunteers from farmer and rancher organizations, state agencies, public power utilities, and higher education institutions have organized the annual Nebraska Wind and Solar Conference and Exhibition to advance these industries in the state. ${ }^{231}$

Nebraska does not have an RPS or a renewable energy goal. In 2017, state legislators proposed LB 504 to establish a 2-year moratorium on wind energy development in Nebraska’s Sandhills region. If approved, the bill would also require the director of the Nebraska Department of Natural Resources to form a special task force to study and make recommendations regarding future wind energy development in the region. The Sandhills region covers nearly a quarter of Nebraska.

Nebraska participated in the original Wind for Schools project through the engagement of the University of Nebraska-Lincoln, with the installation of 24 K-12 partner school systems in the state. The University of Nebraska Wind Applications Center works with those partner schools to enhance their curriculum, career development, and the overall operation of their existing smallscale wind turbines in 2016. Visit the WINDExchange website for information about school wind projects and educational programs in Nebraska and other states. ${ }^{232}$

${ }^{231} \mathrm{http} / / /$ nebraskawindandsolarconference.com/

232 https://windexchange.energy.gov/education-workforce 


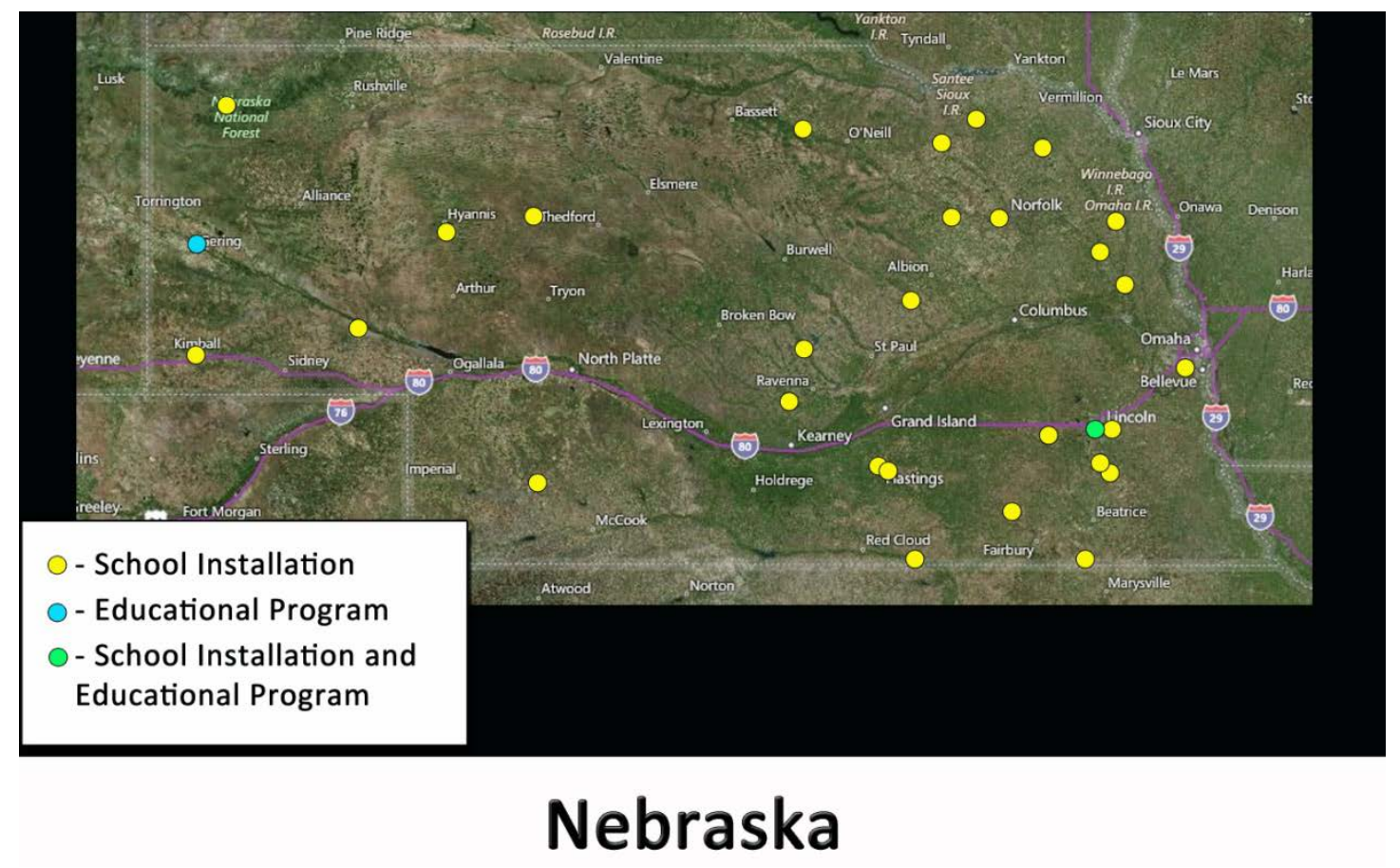

Figure 25. Map of school wind turbine projects, educational programs, and locations with both wind turbines and educational programs in Nebraska

Nebraska has no wind-related manufacturing.

\subsubsection{Oklahoma}

Oklahoma had 7,495 MW of installed wind capacity as of December 2017 (American Wind Energy Association 2018), including .3 MW of distributed wind that was installed between 2003 and 2016 (U.S. Department of Energy 2017a). The state had 1,366 MW of wind projects under construction at the end of December 2017 (American Wind Energy Association 2018). In 2016, wind provided $25 \%$ of all in-state electricity production. At the end of 2016, wind development in Oklahoma represented a \$12.3 billion capital investment (American Wind Energy Association 2017).

In 2010, Oklahoma set a renewable energy target for 15\% of total installed generation capacity for operating electric utilities to be renewable sources by 2015 (DSIRE 2015a). The actual total installed generation capacity for operating electric utilities from renewable sources in 2015 was 25.9\% (Oklahoma Corporation Commission 2016). No further expansion of this goal has been announced (DSIRE 2015a).

Market barriers to wind development in the state include legislation for decommissioning requirements, project siting requirements (specifically setbacks defined by Senate Bill 808 for wind energy projects near schools, hospitals, and airports), as well as notification requirements (Monies 2015b). Some landowners have used the provision established in SB 808 to slow development by registering private airstrips on their property with the Federal Aviation Administration (Monies 2016b). SB 593 was signed in April 2017, eliminating the private-use 
airport designation from the state's new siting requirements while keeping the other previously defined setbacks in place (Monies 2017a).

In other legislative news, the Governor signed a zero-emission tax credit for wind energy in April 2017. The former half-cent tax credit for every kilowatt of electricity from wind energy would have expired January 1, 2021, but was moved up to July 1, 2017. The tax credit, however, will stay in place for other zero emission technologies until the January 1, 2021 expiration date (Monies 2017a).

Along with being utilized in-state, Oklahoma wind energy developments export clean energy to multiple states, including Alabama, Nebraska, Arkansas, and Colorado (Teague 2015). In February 2016, Oklahoma Gas and Electric announced that it was moving up construction of the 126-mile Windspeed II transmission line that will connect Woodward to the company's Cimarron substation northwest of Oklahoma City. The project is expected to be online by mid2018 (Monies 2016a). In July 2017, Public Service Company of Oklahoma and Southwestern Electric Power Company announced a joint transmission project that will connect wind power from the Oklahoma Panhandle to Tulsa. In addition to expanded transmission capabilities, the Wind Catcher Energy Connection Project involves the acquisition of a 2,000-MW wind farm being developed by Invenergy; expected completion date is the end of 2020 (Monies 2017b).

Oklahoma also is home to a national example of the private sector owning, developing, or purchasing directly from wind projects. In 2015, Google announced that it would purchase energy from two new wind projects in Oklahoma to help power its data centers in the state (Monies 2015a).

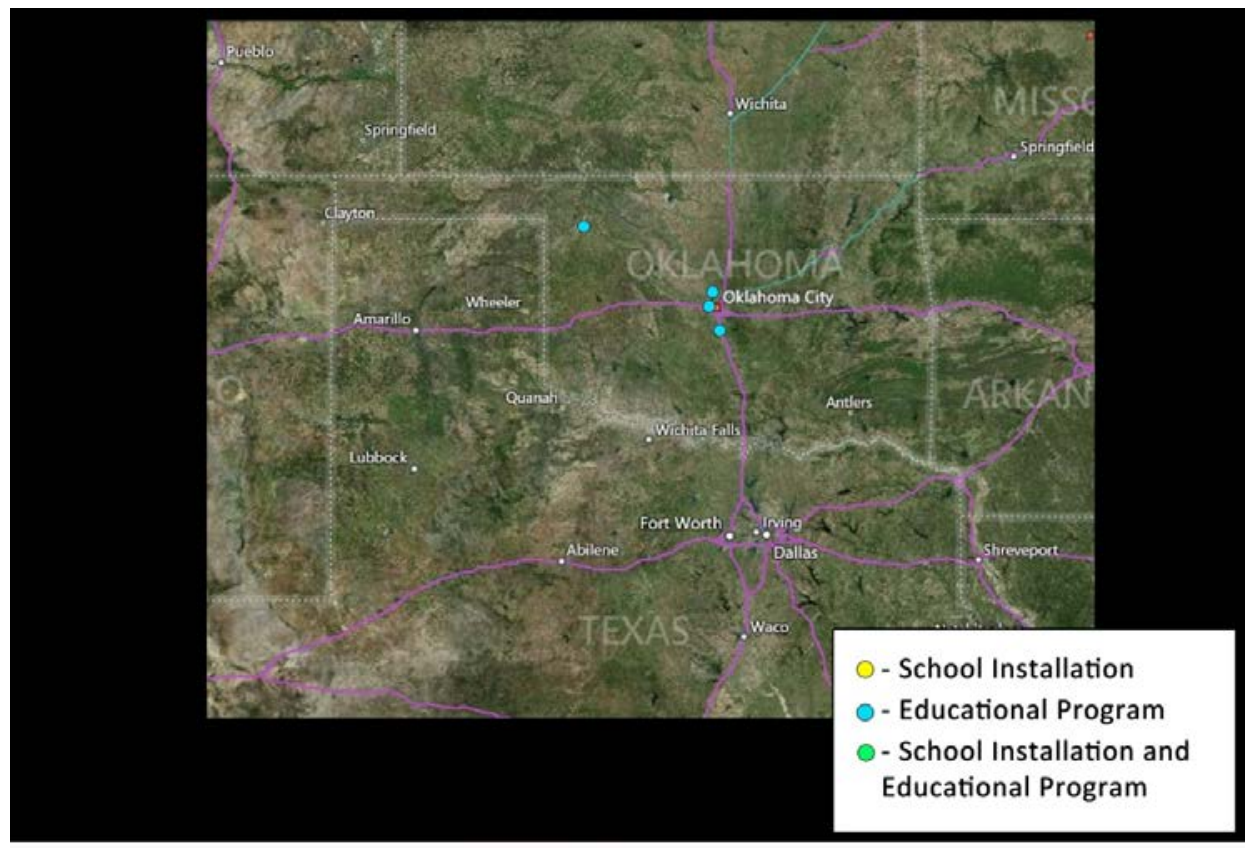

\section{Oklahoma}

Figure 26. Map of school wind educational programs in Oklahoma 
Visit the WINDExchange website for information about school wind projects and educational programs in Oklahoma and other states. ${ }^{233}$

NREL researchers compiled the following Oklahoma wind energy manufacturing data as part of DOE’s annual wind market report effort (U.S. Department of Energy 2017c).

Table 33. Oklahoma Wind-Related Manufacturing Overview

\begin{tabular}{lll}
\hline Name & City & Component \\
\hline Bergey Windpower & Norman & Distributed wind turbines \\
Trinity Structural Towers & Tulsa & Towers \\
\hline
\end{tabular}

\subsubsection{Texas}

As of December 2017, Texas had an installed wind capacity of 22,637 MW, more than any other state in the nation (American Wind Energy Association 2018). The state is also home to 187.7 MW of distributed wind that was installed between 2003 and 2016 (U.S. Department of Energy 2017a). In 2016, wind provided $12.63 \%$ of all in-state electricity production. With 4,143 MW of wind projects under construction as of the end of 2017, the state is looking to expand capacity from this clean energy resource. At the end of 2016, wind development in the Lone Star State represented \$38.4 billion of capital investment (American Wind Energy Association 2017).

Texas established an RPS in 1999 and amended it in 2005. The current RPS requires 5,880 MW of renewable energy by 2015 and a target of 10,000 MW of renewable capacity by 2025 (which the wind energy industry met in 2010) (American Wind Energy Association 2017).

During 2017, new wind energy legislation was proposed and passed in an attempt to limit wind projects near military aviation facilities. Signed by Governor Abbott on June 8, 2017, SB 277 eliminates property tax exemptions for wind projects that are located within 25 nautical miles of military aviation facilities in the state (Lillian 2017b).

New transmission continues to be proposed in the state. In March 2016, Sharyland Utilities proposed a \$77.4 million, 166-mile expansion with the Public Utility Commission of Texas. The project is planned to serve developments that are expected to come online in December 2017 (Welch 2016).

Georgetown, a small city 25 miles north of Austin, announced that its municipal utility, Georgetown Utility Systems, could get 100\% of its electricity from renewable sources by 2017 (Sierra Club 2017). Part of this commitment will be achieved through the purchase of $144 \mathrm{MW}$ from the Spinning Spur 3 wind farm in West Texas.

Corporate ownership and wind energy purchases across the state highlight a market that is becoming more popular. In September 2016, e-commerce giant Amazon announced that it contracted Lincoln Clean Energy to construct, own, and operate the 253-MW Amazon Wind Farm Texas. In return, Amazon will purchase nearly 90\% of the facility's generation to offset

${ }^{233}$ https://windexchange.energy.gov/education-workforce 
energy usage from its Web Services Cloud data centers (Rafique 2016). Construction was completed in the third quarter of 2017 (American Wind Energy Association 2018).

Another development that will be located in Texas, the 148-MW Cactus Hills Wind Project, will support two major corporations in their missions to become more sustainable. General Motors (November 2016) and General Mills (June 2017) both committed to purchasing the project's full capacity, as well as the project's associated renewable energy credits (Southern Power 2017).

In 2017, Texas produced more wind power in a given amount of time than ever in history. The state reached "peak wind" at 3:50 a.m. on March 23, when local wind farms produced 14,391 MW of electricity, or $50 \%$ of the total electricity load of the state's main power grid (ERCOT 2017). On March 31, wind electricity generation in Texas hit a new wind output record of 16,141 MW, representing approximately 39.5\% of total electric demand (S\&P Global Platts 2017).

Texas is home to several wind energy educational programs at Texas Tech University; the University of Houston; and Texas State Technical College, West Texas. Texas Tech University in Lubbock was selected to participate in DOE's Collegiate Wind Competition 2018. Visit the WINDExchange website for information about school wind projects and educational programs in Texas and other states. ${ }^{234}$

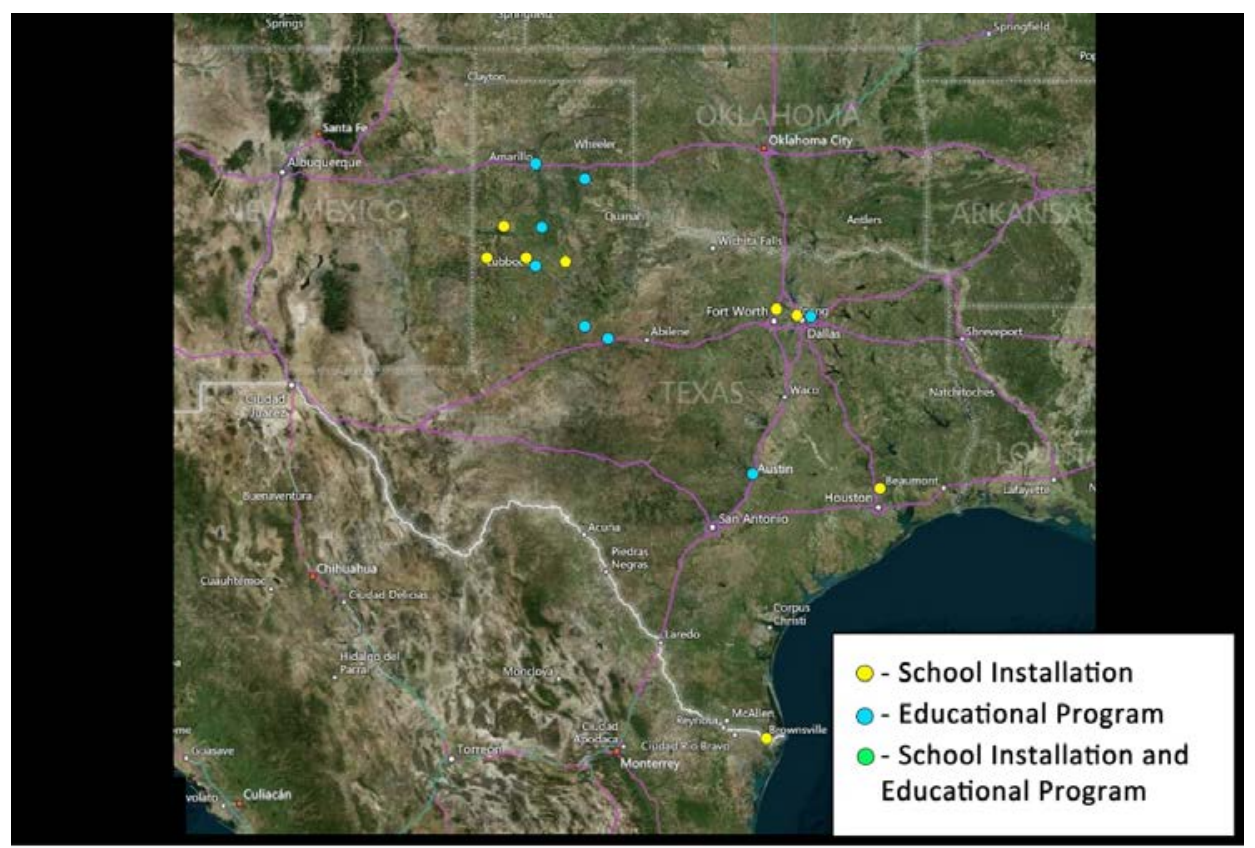

\section{Texas}

Figure 27. Map of school wind turbine projects, educational programs, and locations with both wind turbines and educational programs in Texas

NREL researchers compiled the following Texas wind energy manufacturing data as part of DOE's annual wind market report effort (U.S. Department of Energy 2017c).

\footnotetext{
${ }^{234}$ https://windexchange.energy.gov/education-workforce
} 
Table 34. Texas Wind-Related Manufacturing Overview

\begin{tabular}{lll}
\hline Name & City & Component \\
\hline Alcoa Fasteners & Waco & Fasteners \\
\hline All-Pro Fasteners & Arlington & Bolts \\
\hline Barr Fabrication & Brownwood & Tower internals \\
\hline Broadwind & Abilene & Towers \\
\hline CAB Inc. & Nacogdoches & Flanges \\
\hline CB Gear and Machine & Houston & Gears \\
\hline Diab Inc. & Desoto & Blade cores \\
\hline EMA Electromecanica & Sweetwater & Electronics \\
\hline GRI Renewable Industries & Amarillo & Towers \\
\hline NGC Renewables & Fort Worth & Gearboxes \\
\hline Proinlosa & Houston & Tower internals \\
\hline RBC Bearings & Houston & Bearings \\
\hline
\end{tabular}

\subsubsection{West Virginia}

As of December 2017, West Virginia had 686 MW of installed wind capacity (American Wind Energy Association 2018), including between $1 \mathrm{~kW}$ and $100 \mathrm{~kW}$ of distributed wind capacity installed between 2003 and 2016 (U.S. Department of Energy 2017a). West Virginia wind projects have resulted in 1,432 gigawatt-hours of generation (U.S. Energy Information Administration 2017a). The majority of this generation comes from six projects, including the state's most recent installation: the 103-MW New Wind Creek project that came online in December 2016 (Enbridge Inc. 2017). West Virginia's wind energy development equates to a \$1.4 billion capital investment (American Wind Energy Association 2017).

In early 2015, West Virginia lawmakers repealed the state’s Alternative and Renewable Energy Portfolio Standard that required certain utilities to derive $25 \%$ of their sales from alternative and renewable energy resources by 2025 (Sadasivam 2015). An additional legislative effort that has the potential to affect the development of wind energy in West Virginia began taking root as the state senate voted to repeal a 2001 tax break on March 18, 2017. SB 16 would revoke the current classification of wind turbines as pollution control facilities, allowing projects to be taxed at full valuation instead of the present 5\% tax (Zuckerman 2017). The legislation moved to West Virginia's House of Delegates, but the regular legislative session ended in April without it moving out of committee. It will likely be reconsidered in 2018.

While wind energy accounted for 1.9\% of the state's net electricity generation at the end of 2016 (American Wind Energy Association 2017), coal-fired electric power plants continued to dominate in the state, accounting for $94 \%$ of net electricity generation (U.S. Energy Information Administration 2017b). Increased diversification of the state's energy generation was announced in 2015 as West Virginia's utilities were required to release integrated resource plans to the public that identify energy sources to meet future demand. Although most of the state's utilities intend to rely on continued coal generation, Appalachian Power anticipates the acquisition of 750 MW of wind generation that will help to diversify its energy portfolio while addressing future 
energy needs (Brown 2016). As part of this effort, the company announced that it would seek regulatory approval from the West Virginia Public Service Commission and the Virginia State Corporation Commission to acquire $225 \mathrm{MW}$ of wind energy from two projects, including 50 MW from the Beech Ridge II Wind Facility that will be located in the state. The 175-MW Hardin Wind Facility will be located in Ohio. Both facilities are expected to be online in 2018 (Garland 2017).

Wildlife concerns, primarily related to bats, continue to impact project development in the state. Land use issues regarding mountain top mining impacts in the southern part of the state have also created challenges as the practice can alter bedrock stability in the area and lower mountain elevation. The reduced heights of mountain areas can result in an inability to capture more productive wind resource (Dutton et al. 2014).

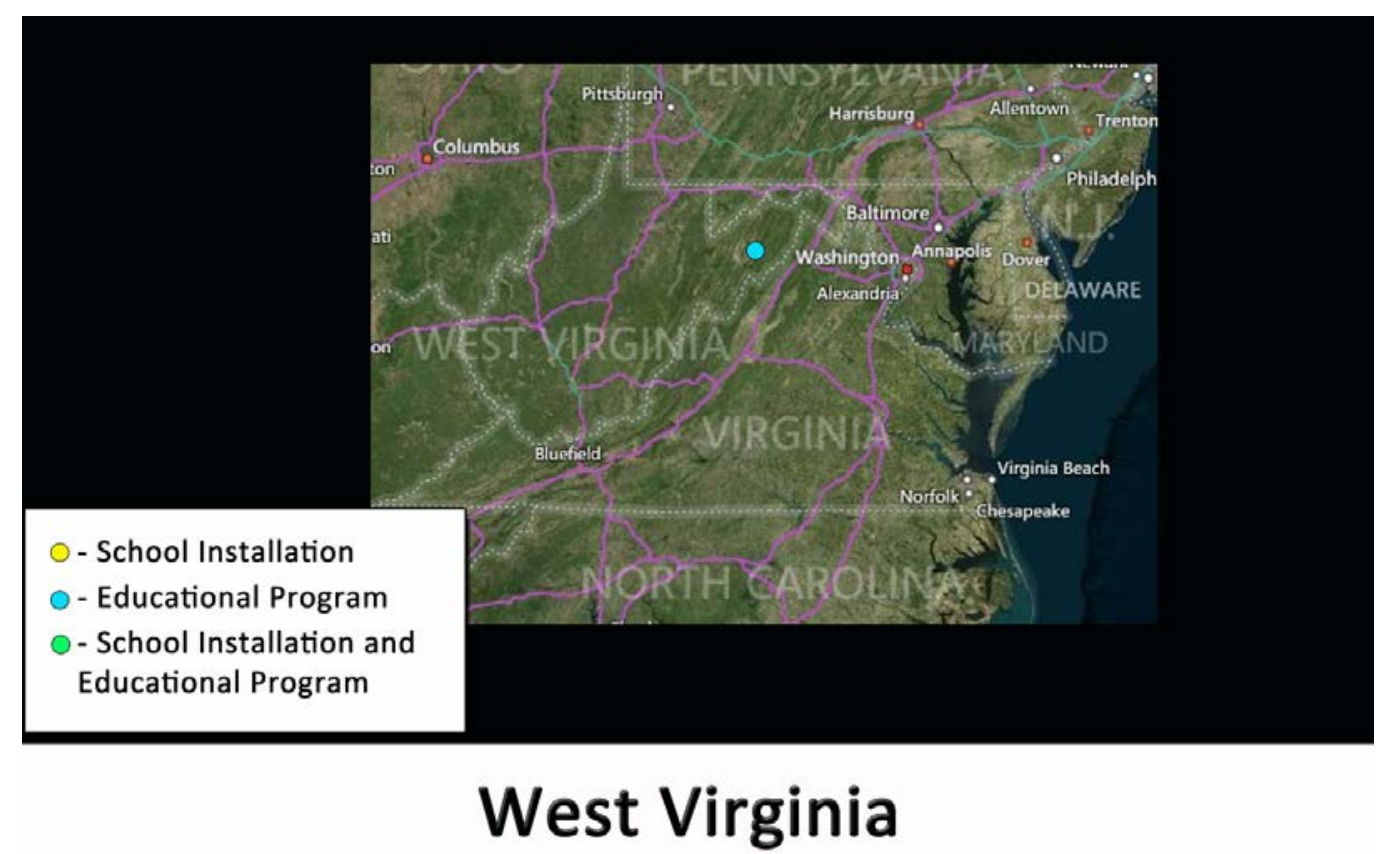

Figure 28. Map of sole school wind educational program in West Virginia

Visit the WINDExchange website ${ }^{235}$ for information about education programs and workforce development in West Virginia and other states.

West Virginia has no wind-related manufacturing.

${ }^{235}$ https://windexchange.energy.gov/education-workforce 


\section{References}

Advanced Energy Economy. June 16, 2017. “Florida Gov. Scott Signs Renewables Bill.” https://www.aee.net/articles/florida-gov-scott-signs-renewables-bill

Alabama Power. 2016a. “Chisholm View, Buffalo Dunes projects provide cost-effective power.” Accessed October 22, 2016. http://www.alabamapower.com/environment/news/chisholm-viewproject-provides-low-cost-power.asp

Alabama Power. 2016b. “Alabama Power Request for Proposals.” Accessed June 14, 2017. http://www.alabamapower.com/content/dam/alabamapower/Our\%20Company/The\%20Environ ment/Renewables/RFP/RFP-Main-Document.pdf

Altman, Isabell. 2017. "Southern Cross Submits Route Plan.” The Columbus Dispatch, April 26. http://www.cdispatch.com/news/article.asp?aid=57801

Ameren. September 25, 2017. “Ameren Missouri Plans Major Expansion of Wind, Solar Generation to Serve Customers.” http://ameren.mediaroom.com/2017-09-25-Ameren-MissouriPlans-Major-Expansion-of-Wind-Solar-Generation-to-Serve-Customers

American Samoa Renewable Energy Committee. 2017. “Manu’a Islands 100\% Renewable Energy.” Accessed September 11, 2017. http://www.asrec.net/2017/05/24/manua-islands-100renewable-energy/

American Wind Energy Association. 2017a. “U.S. Wind Energy State Facts.” Accessed August 24, 2017. http://www.awea.org/resources/statefactsheets.aspx?itemnumber=890\&navItemNumber=5067

American Wind Energy Association. 2017b. “U.S. Wind Industry Annual Market Report.” Accessed September 5, 2017.

American Wind Energy Association. 2017c. “U.S. Wind Industry Third Quarter 2017 Market Report.” Accessed November 5, 2017. https://www.awea.org/About/content.aspx?ItemNumber=11147

American Wind Energy Association. 2017d. "Wind Energy Facts at a Glance.” Accessed January 6, 2018. https://www.awea.org/wind-energy-facts-at-a-glance

American Wind Energy Association. 2018. "U.S. Wind Industry Fourth Quarter 2017 Market Report.” Accessed March 8, 2018. http://awea.files.cmsplus.com/FileDownloads/pdfs/4Q\%202017\%20AWEA\%20Market\%20Report\%20Public\%20Ve rsion.pdf

Apex Clean Energy. Timbermill Wind. Accessed December 9, 2016. http://www.timbermillwind.com/ 
Baranowski, Ruth; Oteri, Frank; Baring-Gould, Ian.; and Suzanne Tegen. 2017. 2016 State of Wind Development in the Regions. NREL-TP-5000-67624. National Renewable Energy Laboratory (NREL), Golden, CO (US). https://www.nrel.gov/docs/fy17osti/67624.pdf

Boshart, Rod. 2017. “Iowa Lands Apple Data Center.” Quad City Times, August 24. http://qctimes.com/business/iowa-lands-apple-data-center/article_04d34da9-21ab-51da-acfb15fbf4218910.html

Boughton, Kathryn. 2015. “Wind Energy Turbines Rising.” Republican-American, August 4. http://rep-am.com/articles/2015/08/04/news/local/899126.txt

Brean, Henry. 2017. “Developer Pulls Plug on Proposed Wind Farm near Searchlight.” Las Vegas Review Journal, April 25. https://www.reviewjournal.com/local/local-nevada/developerpulls-plug-on-proposed-wind-farm-near-searchlight/

Brown, Andrew. 2016. “Appalachian Power Moves toward Renewables, Mon Power Considering More Investments in Coal.” Charleston Gazette Mail, January 9. http://www.wvgazettemail.com/business/20160109/appalachian-power-moves-towardrenewables-mon-power-considering-more-investments-in-coal

Brunner, Colleen. 2016. "Butte Electric Notes 76 years of Service.” Butte County Post, November 6. http://rapidcityjournal.com/news/local/communities/belle_fourche/butte-electricnotes-years-of-service/article_d4906726-5b65-5a0d-869f-c98f2482840b.html

Bureau of Ocean Energy Management. 2016. Commercial Lease for Wind Energy Offshore Virginia. Accessed October 22, 2016. http://www.boem.gov/Renewable-EnergyProgram/Commercial-Lease-Offshore-VA/

California Energy Commission. 2016a. California Renewable Energy Overview and Programs. http://www.energy.ca.gov/renewables/

Charney, Alberta H., Valorie Rice, Marshall J. Vest, Anthony V. Popp, James Peach, and Leo Delgado. 2011. SunZia Southwest Transmission Project Economic Impact Assessment. Accessed July 13, 2016. http://www.sunzia.net/documents_pdfs/sunzia_eia_revised_final_jan_2012.pdf

Chugach Electric. 2017. "Utilities Sign Power Pooling Agreement, Collaboration to Save Millions for Railbelt Customers.” January 30. https://www.chugachelectric.com/system/files/press_releases/power_pooling_30_jan_2017.pdf

Clean Energy Group. December 19, 2016. Statoil Wins New York Offshore Wind Auction. http://www.cleanegroup.org/statoil-wins-new-york-offshore-wind-auction/

Clean Line Energy Partners. 2016a. Clean Line Energy and Others Ask Illinois Supreme Court to Decide the fate of Wind Energy Power Line, September 14. Accessed September 20, 2016. http://www.cleanlineenergy.com/sites/cleanline/media/news/PLA_Filing_press_release.pdf

Clean Line Energy Partners. 2016b. Grain Belt Express Clean Line Schedule. Accessed September 20, 2016. http://www.grainbeltexpresscleanline.com/site/page/schedule 
Clean Line Energy Partners. 2017. Grain Belt Express Clean Line Overview. http://www.grainbeltexpresscleanline.com/site/page/project_description

Congressional Research Service. (December 29, 2014). Federal Land Ownership: Overview and Data. https://www.fas.org/sgp/crs/misc/R42346.pdf

Crash, Tom. 2017. “OST Committed to Oceti Sakowin Power Authority.” Lakota Country Times, July 13. http://www.lakotacountrytimes.com/news/2017-0713/Headlines/OST_Committed_To_Oceti_Sakowin_Power_Authority.html

Daniels, Steve. 2017. "Supreme Court Ruling Leaves Wind-Power Line up in the Air.” Crain's Chicago Business, September 21. http://www.chicagobusiness.com/article/20170921/NEWS11/170929969/supreme-court-rulingleaves-wind-power-line-up-in-the-air

Delmarva Power and Light Company. February 17, 2017. Request for Proposals for Wind Renewable Energy Credits.

http://www.delmarva.com/uploadedFiles/wwwdelmarvacom/Content/Page_Content/My_Busines s/DPL\%20DE\%20Wind\%20REC\%20RFP.pdf

Dillon, Liam. 2017. “California Plan for 100\% Renewable Energy by 2045 Clears Key Hurdle.” The Los Angeles Times, May 31. http://www.latimes.com/politics/essential/la-pol-ca-essentialpolitics-updates-california-plan-for-100-renewable-1496258464-htmlstory.html

Doerr, Alissa. 2015. Zoned Out: An Analysis of Wind Energy Zoning in Four Midwest States. Center for Rural Affairs. http://www.cfra.org/zoned-out-wind-energy-analysis

Dominion Power. 2016. “Dominion Virginia Power Considers Options for Offshore Wind Demonstration Project after Federal Grant Withdrawal.” https://www.dom.com/corporate/news/news-releases/137136

DONG Energy. December 14, 2016. "DONG Energy Wind Power U.S. Inc. and Eversource Announce Partnership to Make Large-Scale Offshore Wind a Reality in the United States.” http:/www.dongenergy.com/en/media/newsroom/news/articles/partnership-to-make-large-scaleoffshore-wind-a-reality-in-the-us

DSIRE. 2015a. Oklahoma Renewable Energy Goal, last modified December 15, 2015. http://programs.dsireusa.org/system/program/detail/4178

DSIRE. 2016. Renewable Energy Standard Program Overview, last modified November 4, 2016. http://programs.dsireusa.org/system/program/detail/5786

Dumat-Ol Daleno, Gaynor. 2016. “GPA’s First Wind Turbine Begins Test Run.” Pacific Daily News, January 12. http://www.guampdn.com/story/news/2016/01/12/gpas-first-wind-turbinebegins-test-run/78670908/ 
Dutton, James; King, Adam; and Catrina Sedgwick. 2014. "Renewable Energy Source for West Virginia is Blowing in the Wind.” Mountaineer News Service, February 13.

http://mountaineernewsservice.com/renewable-energy-source-for-west-virginia-is-blowing-inthe-wind/

Edison International. 2017. “Tehachapi Renewable Transmission Project.” Accessed August 25, 2017.

Electric Cooperatives of Arkansas. 2014. “Arkansas Electric Cooperative Corporation adds 150 megawatts of wind energy.” Accessed October 22, 2016.

https://www.aecc.com/sites/aecc.com/files/Wind\%20Capacity\%2011-26-14.pdf

Electric Cooperatives of Arkansas. 2015. “Arkansas Electric Cooperative Corporation adds 108 megawatts of wind energy.” Accessed October 22, 2016.

https://www.aecc.com/sites/aecc.com/files/Drift\%20Sand.pdf

Enbridge Inc. 2017. "Enbridge Reports Fourth Quarter 2016 Results.”

https://www.enbridge.com/media-center/news/details?id=2124916\&lang=en\&year=2017.

Accessed August 25, 2017.

Enel Green Power. January 3, 2017. "Enel Green Power North America Completes First 200

MW of Cimarron Bend in Kansas.” https://www.enelgreenpower.com/en/media/news/d201701enel-green-power-north-america-completes-first-200-mw-of-cimarron-bend-in-kansas.html

ERCOT Grid Operations. March 23, 2017. ERCOT Grid Operations Wind Integration Report 03/23/17. https://t.co/cV4fTceeEW

Faircloth, Ryan. 2017. “Mower Ranks First in Wind Tax Revenue.” Post Bulletin, June 23. http:/www.postbulletin.com/news/local/mower-ranks-first-in-wind-tax-

revenue/article_315d1bdb-aa31-50e5-91ec-663de42f9399.html

Flitter, Emily. 2017. “Two Ohio Coal-Fired Plants to Close, Deepening Industry Decline.” Reuters, March 20. http://www.reuters.com/article/us-usa-coal-closures/two-ohio-coal-firedplants-to-close-deepening-industry-decline-idUSKBN16R2D4

Garland, Max. 2017. “Appalachian Power Looks to Acquire Planned Wind Power Projects, One in West Virginia.” Charleston Gazette Mail, July 5.

Georgia Power. 2016. Georgia Power Company’s 2016 Integrated Resource Plan and Application for Decertification of Plant Mitchell Units 3, 4A and 4B, Plant Kraft Unit 1CT, and Intercession City CT Docket No. 40161.” Accessed October 22, 2016.

http://mediad.publicbroadcasting.net/p/wabe/files/201602/2016_irp_main_doc_pdf_pdf

Georgia Public Service Commission. 2014. Commission Approves Wind Power Electric Generation as Part of Georgia Power Company’s Resource Mix. Accessed October 22, 2016. http://www.psc.state.ga.us/GetNewsRecordAttachment.aspx?ID=447 
Gray, Bryce. 2017. "New Route for Ameren's Northeast Missouri Transmission Line Gains Local Approval.” St. Louis Post Dispatch, September 6.

http://www.stltoday.com/business/local/new-route-for-ameren-s-northeast-missouritransmission-line-gains/article_4ab07f72-3ee6-5dc1-b32d-ab775cb2812f.html

Green, John. 2017. “Siemens Gamesa Announces Mass Layoff at Hutchinson Plant.” The Hutchinson News, August 18. http://www.hutchnews.com/news/20170818/siemens-gamesaannounces-mass-layoff-at-hutchinson-plant

Guam Consolidated Commission on Utilities. 2017. Resolution No. 2017-06. http://guamccu.org/wp-content/uploads/2015/12/Resolution-2017-06-Relative-to-EnergyStorage-Contract-Phase-I_LGCNS.pdf

Hammack, Laurence. 2016. "Botetourt County approves wind farm permit unanimously.” The Roanoke Times, January 26. http://www.roanoke.com/news/local/botetourt_county/botetourtcounty-approves-wind-farm-permit-unanimously/article_de52c1c7-6099-5894-8a3f$\underline{\text { 0d19a02f9c63.html }}$

Hammack, Laurence. 2017. "Botetourt Wind Farm Developer to Start Work in Winter; Still Lacks Buyer for Electricity.” The Roanoke Times, July 25. http://www.roanoke.com/news/local/botetourt_county/botetourt-wind-farm-developer-to-startwork-in-winter-still/article_f389efcb-af34-5894-bbf2-ec482a6e3c46.html

Hansel, Jeff. 2016. "Hawaiian Electric Companies Seek Potential Land for Renewable Energy Production.” Hawaii Tribune Herald, December 13. http://hawaiitribune-herald.com/news/localnews/hawaiian-electric-companies-seek-potential-land-renewable-energy-production

Hubbuch, Chris. 2017. “Dairyland Power Wind Agreement Boosts Renewable Portfolio.” La Crosse Tribune, February 15. http://lacrossetribune.com/news/local/dairyland-power-windagreement-boosts-renewable-portfolio/article_9315cd10-1356-5cac-9df0-f2a9fd641fcc.html

Humphrey, Tom. 2017. “Developer Suspends \$100M Cumberland County Wind Turbine Project.” Tennessee Journal, June 13. http://humphreyonthehill.tnjournal.net/developersuspends-plans-for-100m-cumberland-county-wind-turbine-project/

ISO-New England. (September 20, 2016). Memo: Proposed Clustering Methodology in the ISO New England Interconnection Queue. https://www.iso-ne.com/staticassets/documents/2016/09/2016_09_27_tca06_clustering.pdf

ITC. February 23, 2017. Capital Project Profile: Elm Creek-Summit Transmission Line. http://www.itc-holdings.com/docs/default-source/project-documents/kansas---elm-creeksummit/itcgp-profile_elmcrk-summit_022317.pdf?sfvrsn=4

Jimenez, Tony; Keyser, David; and Suzanne Tegen. 2016a. Floating Offshore Wind in Hawaii: Potential for Jobs and Economic Impacts from Two Future Scenarios. NREL/TP-5000-65481. National Renewable Energy Laboratory (NREL), Golden, CO (US). http://www.nrel.gov/docs/fy16osti/65481.pdf 
Jimenez, Tony; Keyser, David; and Suzanne Tegen. 2016b. Floating Offshore Wind in Oregon: Potential for Jobs and Economic Impacts in Oregon Coastal Counties from Two Future Scenarios. NREL/TP-5000-65432. National Renewable Energy Laboratory (NREL), Golden, CO (US). http://www.nrel.gov/docs/fy16osti/65432.pdf

Jimenez, Tony; Keyser, David; Tegen, Suzanne; and Bethany Speer. 2016c. Floating Offshore Wind in Oregon: Potential for Jobs and Economic Impacts from Two Future Scenarios. NREL/TP-5000-65421. National Renewable Energy Laboratory (NREL), Golden, CO (US). http://www.nrel.gov/docs/fy16osti/65421.pdf

Joseph, Carl. September 27, 2016. U.S. Virgin Islands Energy Office; personal conversation

Kelly, Niki. 2017. “Holcomb Signs Solar Energy Bill.” The Journal Gazette, May 3. http://www.journalgazette.net/news/local/indiana/20170503/holcomb-signs-solar-energy-bill

King, James; Schiavanato, Lisa; and Ethan Case. 2016. Wind Energy Permitting in North Carolina and Six Other States: A Comparative Analysis. https://ncseagrant.ncsu.edu/ncseagrant_docs/products/2010s/NC_Wind_Analysis_Final.pdf

King-Homan, Laura and Roger, Andrew. 2016. "Transmission Line Will Ease Energy Flow Congestion.” The Wire, December 15. https://oppdthewire.com/oppd-mtp-transmission-line/

Kuckro, Rod. 2016. "Report: State Renewable Energy Standards Succeeding, at Little Cost." EnergyWire, April 8. http://midwestenergynews.com/2016/04/08/report-state-renewable-energystandards-succeeding-at-little-cost/

Legislature of Nebraska. January 18, 2017. Legislative Bill 504. http://nebraskalegislature.gov/FloorDocs/105/PDF/Intro/LB504.pdf

Lillian, Betsy. 2016. "BOEM Completes Initial Review of Huge Wind Farm Offshore California.” North American Windpower, March 21. http://nawindpower.com/boem-completesinitial-review-of-huge-wind-farm-offshore-california

Lillian, Betsy. 2017a. "Ohio Parties Agree to Kill Coal Plants, Add More Wind and Solar.” North American Windpower, January 31. http://nawindpower.com/ohio-parties-agree-to-killcoal-plants-add-more-wind-and-solar

Lillian, Betsy. 2017b. “Texas Governor Signs Tax Exemption Bill for Wind Near Military Airfields.” North American Windpower, June 12. http://nawindpower.com/texas-governor-signstax-credit-bill-wind-near-military-airfields

Louisiana Wind. http://www.lawind.com/blog/wpcontent/themes/twentythirteen/images/Flyer2.pdf. Accessed October 4, 2017.

MacArthur, Anita Rose. 2017. “AVEC Looking for a New Wind Turbine Site after FAA Scraps Utility’s Plans.” KYUK, August 27. http://kyuk.org/post/avec-looking-new-wind-turbine-siteafter-faa-scraps-utilitys-plans 
Mai, Trieu; Lantz, Eric; Mowers, Matthew; and Ryan Wiser. The Value of Wind Technology Innovation: Implications for the U.S. Power System, Wind Industry, Electricity Consumers, and Environment. NREL/TP-5000-70032. National Renewable Energy Laboratory (NREL), Golden, CO (US). https://www.nrel.gov/docs/fy17osti/70032.pdf

Maryland Coast Dispatch. 2011. "Delaware Wind Contract Cancelled.” http://mdcoastdispatch.com/2011/12/29/del-wind-contract-cancelled/

Maryland Public Service Commission. 2017a. "Maryland PSC Awards ORECS to Two Offshore Wind Developers.” http://www.psc.state.md.us/wp-content/uploads/PSC-Awards-ORECs-to-USWind-Skipjack.pdf

Maryland Public Service Commission. 2017b. Order No. 88260. http://www.psc.state.md.us/wpcontent/uploads/Order-No.-88260-Case-No.-9413-Affirming-Proposed-Order-of-PULJ.pdf

Massachusetts Clean Energy Center. (March 26, 2014). "Energy Officials Approve Relief Funding for Falmouth Community Wind Project.” http://www.masscec.com/aboutmasscec/news/energy-officials-approve-relief-funding-falmouth-community-wind-project

Mass Energy Consumers Alliance. "Local Wind Turbines, Sources of Green Power for Our Members.” Accessed February 7, 2016. https://www.massenergy.org/renewable-energy/wind

Matheny, Keith. 2017. “DTE Plans for No Coal Plants, 80\% Cut in Carbon by 2050.” Detroit Free Press, May 16. http://www.freep.com/story/news/local/michigan/2017/05/16/dte-planscoal-plants-carbon/324991001/

Microsoft. November 14, 2016. "Microsoft Announces Largest Wind Energy Purchase to Date." https://news.microsoft.com/2016/11/14/microsoft-announces-largest-wind-energy-purchase-to$\underline{\text { date/ }}$

MidAmerican Energy. 2016. Construction Completed on New Transmission Line in Northeast Iowa. https://www.midamericanenergy.com/news-article.aspx?story=803. Accessed 8 October 2017.

MidAmerican Energy. 2017. Our 100\% Renewable Energy Vision. https://www.midamericanenergy.com/our-renewable-energy-vision.aspx. Accessed 4 October 2017.

Midwest Transmission Project. 2013. The Midwest Transmission Project. http://midwesttransmissionproject.com/Default.htm

Monies, Paul. 2015a. "Duke Energy, Google Announce Deals for Three Oklahoma Wind Power Projects.” The Oklahoman, December 4. http://newsok.com/article/5464636

Monies, Paul. 2015b. "Oklahoma Bill Puts Siting Restrictions and Reporting Requirements on Wind Farms.” The Oklahoman, April 1. http://newsok.com/article/5406313 
Monies, Paul. 2016a. “OG\&E Expedites Work on New Wind Power Line.” The Oklahoman, February 26. http://newsok.com/article/5481566

Monies, Paul. 2016b. “Oklahoma Landowners Register Private Airstrips to Keep Wind Farms at Bay.” The Oklahoman, May 22. http://newsok.com/oklahoma-landowners-register-privateairstrips-to-keep-wind-farms-at-bay/article/5499575

Monies, Paul. 2017a. “Oklahoma Governor Signs Bills to End Wind Incentive, Airfield Loophole.” The Oklahoman, April 18. http://newsok.com/article/5545841

Monies, Paul. 2017b. "PSO, Sister Utility Team up on \$4.5 Billion Oklahoma Wind Farm, Transmission Project.” The Oklahoman, July 26. http://newsok.com/article/5557773

Monti, Marti; Stephen Rose; Kimberley A. Mullins; Elizabeth J. Wilson. 2016. “Transmission Planning and CapX 2020: Building Trust to Build Regional Transmission Systems.” Accessed October 22, 2016. https://www.hhh.umn.edu/sites/hhh.umn.edu/files/capx2020_final_report.pdf

Mora, Kyla. 2017. "Sen. Telena Nelson Backs Bill to Create Task Force, Promote Renewable Energy Options.” Pacific Daily News, April 21. http://www.guampdn.com/story/money/2017/04/21/sen-telena-nelson-backs-bill-create-taskforce-promote-renewable-energy-options/100728958/

Morris, Allie. 2014. "Iberdrola Abandons Wild Meadows Wind Farm, Raising Questions about Future of Wind Power in New Hampshire.” Concord Monitor, May 28.

http:/www.concordmonitor.com/news/nation/world/12150881-95/ibredrola-abandons-wildmeadows-wind-farm-raising-questions-about-future-of-wind-power-in

Moss, Rebecca. 2017. “Fate of Surviving Solar Bills in Martinez’s Hands.” The Santa Fe New Mexican, March 24. http://www.santafenewmexican.com/news/legislature/fate-of-survivingsolar-bills-in-martinez-s-hands/article_0bd5951b-22d2-5252-b579-171e631d34e1.html

Murawski, John. 2015. "NC Coastal Residents Sue to Block Amazon Wind Farm.” The News \& Observer, October 1. http://www.newsobserver.com/news/business/article37244796.html

Murawski, John. 2017 “Amazon Wind Farm Developer Avangrid Wins \$9m Bid to Build Offshore Wind Farm off Kitty Hawk.” The News \& Observer, March 16. http://www.newsobserver.com/news/business/article138865738.html

Murray, Patty. 2017. "NextEra Energy Plans State's Largest Solar Plant in Two Rivers.” Wisconsin Public Radio, February 1. https://www.wpr.org/nextera\%C2\%A0energy-plans-stateslargest-solar-plant-two-rivers

National Renewable Energy Laboratory. 2015a. Energy Transition Initiative: Energy Snapshot, Commonwealth of the Northern Mariana Islands. DOE/GO-102015-4683. http://www.nrel.gov/docs/fy15osti/64293.pdf

National Renewable Energy Laboratory. 2015b. Energy Transition Initiative: Energy Snapshot, U.S. Virgin Islands. http://www.nrel.gov/docs/fy15osti/62701.pdf 
Nebraska Public Power District. NPPD Announces Final R-Project Transmission Line Route. Last modified January 26, 2015. http://www.nppd.com/2015/nppd-announces-final-r-project$\underline{\text { transmission-line-route/ }}$

New Mexico Energy, Minerals and Natural Resources Department. February 2015. Economic Analysis of the New Mexico Renewable Energy Production Tax Credit.

http://www.emnrd.state.nm.us/ECMD/CleanEnergyTaxIncentives/documents/REPTCFinalRepor $\underline{\text { tFeb2015.pdf }}$

North Carolina Office of the Governor. 2013. "Governor Pat McCrory signs wind energy bill into law in support of all-of-the-above energy plan.” May 17, http://governor.nc.gov/pressrelease/governor-pat-mccrory-signs-wind-energy-bill-law-support-\%E2\%80\%9Callabove\%E2\%80\%9D-energy-plan

Nunez, Lissette. 2017. “Crisfield Wind Turbine Project Close to Completion.” WMDT, March 13. http://www.wmdt.com/news/maryland/crisfield-wind-turbine-project-close-tocompletion/393665437

O’Connor, Brian. 2017. “\$50 Million Wind Farm Plan Breezes through WAPA Board.” The Virgin Islands Daily News, August 26. http://www.virginislandsdailynews.com/news/millionwind-farm-plan-breezes-through-wapa-board/article_ca93fd95-75be-5022-9ab424042973cc38.html

Oklahoma Corporation Commission. June 2016. “The Oklahoma Corporation Commission’s 2016 Report on the Oklahoma Energy Security Act.”

http://www.occeweb.com/pu/PUD\%20Reports\%20Page/2016ReportRenewableEnergyGoals.pdf

Omaha Public Power District. July 13, 2017. “OPPD Adding More to Its Wind Portfolio.” http://www.oppd.com/news-resources/news-releases/2017/july/oppd-adding-more-wind-to-itsportfolio/

Ozarks Electric Cooperative Corporation. 2012. "Arkansas Electric Cooperative Corporation Adds Wind Capacity.” Accessed October 22, 2016.

http://www.ozarksecc.com/newsblog/arkansas-electric-cooperative-corporation-adds-windcapacity

Pennsylvania Public Utility Commission 2016. Pennsylvania Alternative Energy Portfolio Standard Program. Accessed February 7, 2016. http://www.pennaeps.com/aboutaeps/

Peters, Benjamin. 2017. "PSC Reluctantly Denies Clean Line’s Application for a Third Time.” The Missouri Times, August 16. http://themissouritimes.com/43208/psc-reluctantly-denies-cleanlines-application-third-time/

Pillion, Dennis. 2015. "PSC approves Alabama Power's renewable energy project request, with modifications.” AL.com, September 1.

http://www.al.com/news/index.ssf/2015/09/psc_approves_alabama_powers_re.html 
Power Engineering. December 6, 2016. “Alabama Power RFP Results in 200 Renewable Project Proposals.” http://www.power-eng.com/articles/2016/12/alabama-power-rfp-results-in-200renewable-project-proposals.html

Preedom, Matthew. 2015. “Wind Turbines: Do Property Values Fall?” Milton Independent, August 27. http://www.miltonindependent.com/wind-turbines-do-property-values-fall/

PR Newswire. December 12, 2012. "Pattern's Spring Valley Wins Wind Project of the Year Award.” https://www.prnewswire.com/news-releases/patterns-spring-valley-wins-wind-projectof-the-year-award-183188621.html

Public Service Commission of the State of Missouri. July 13, 2016. File No. EA-2016-0358. https://psc.mo.gov/CMSInternetData/ON/Orders/2016/071316358.pdf

Rafique, Sarah. 2016. “Amazon Wind Farm in the Works for West Texas.” Amarillo Globe News, September 16. http://amarillo.com/news/latest-news/2016-09-16/amazon-wind-farmworks-west-texas

Randazzo, Ryan. 2017. "Navajo Nation OKs New Lease for Navajo Generating Station Coal Plant.” azcentral, June 26.

https://www.azcentral.com/story/money/business/energy/2017/06/27/navajo-nation-coal-plantlease-navajo-generating-station/429864001/

Respaut, Robin. 2017. “Alaska Governor Urges Budget Compromise to Avoid State Shutdown.” Reuters, June 6. https://www.reuters.com/article/us-alaska-budget/alaska-governor-urges-budgetcompromise-to-avoid-state-shutdown-idUSKBN18X331

Ring, Wilson. 2015. “Vermont Taking Breather from Wind Power.” Burlington Free Press, April 13. http://www.burlingtonfreepress.com/story/news/2015/04/13/vermont-taking-breatherfrom-wind-power/25700545/

Robinson-Avila, Kevin. 2017. "PNM Plan Calls for Eliminating Coal Generation.” Albuquerque Journal, April 21. https://www.abqjournal.com/990933/pnm-says-it-can-be-coal-free-by2031.html

Rose, Gale. 2016. “Wind Turbines Generate Revenue in Neighboring County.” The Pratt Tribune, February 27. http://www.pratttribune.com/news/20160227/wind-turbines-generaterevenue-in-neighboring-county

Roth, Sammy. 2015. “After 7 Years, Desert Renewable Energy Plan Finalized.” The Desert Sun, November 10. http://www.desertsun.com/story/tech/science/energy/2015/11/10/after-7-yearsdesert-renewable-energy-plan-finalized/75468628/

S\&P Global Platts. April 3, 2017. "ERCOT sets record wind output Friday.” https://www.platts.com/latest-news/electric-power/houston/ercot-sets-record-wind-output-friday$\underline{21339374}$ 
Sadasivam, Naveena. 2015. “In W.Va., New GOP Majority Defangs Renewable Energy Law That Never Had a Bite.” Inside Climate News, February 5.

http://insideclimatenews.org/news/20150205/wva-new-gop-majority-defangs-renewable-energylaw-never-had-bite

Saint Francis University. 2017. “Pennsylvania Wind Farms.” Accessed September 12, 2017. https://www.francis.edu/Pennsylvania-Wind-Farms/.

Seufert, Dan. 2014. "Plug Pulled on \$150M Wind Farm over Unfriendly Political, Regulatory Climate.” New Hampshire Union Leader, May 27.

http://www.unionleader.com/apps/pbcs.dll/article?AID=/20140527/NEWS05/140529161

Shelbyville Daily Union. 2016. “Missouri PSC Rejects New Grain Belt Application.” July 14. http://www.shelbyvilledailyunion.com/news/local_news/missouri-psc-rejects-new-grain-beltapplication/article_e93ab731-3f94-5275-8f81-24a5c1a6700c.html

Sierra Club. 2017. “Is Your City \#ReadyFor100?” http://www.sierraclub.org/ready-for100/cities-ready-for-100

Skidaway Campus Notes. 2016. “Meteorological tower erected on campus.”Accessed October 22, 2016. https://skidawaycampusnotes.com/tag/wind-energy/

SNL. 2015. "After dropping plans for Kemper IGCC stake, Mississippi co-op to buy wind power.” Accessed October 22, 2016. https://www.snl.com/Interactivex/article.aspx?CdId=A$\underline{32821399-10800}$

Southern Power. July 2017. Cactus Flats Wind Facility. https://www.southerncompany.com/content/dam/southerncompany/pdf/southernpower/Cactus_Flats_Wind_Facility_factsheet.pdf

Southern Wind Energy Association. 2016. Louisiana Wind Energy Opportunities. http://www.southernwind.org/uploads/1/9/8/9/19892499/swea_louisiana_fact_sheet_2016.pdf

Southwestern Electric Power Company. "Wind Power Purchases.” Accessed October 22, 2016. https://www.swepco.com/info/projects/WindPowerPurchase/

Speer, Bethany; Keyser, David; and Suzanne Tegen. 2016. Floating Offshore Wind in California: Gross Potential for Jobs and Economic Impacts from Two Future Scenarios. NREL/TP-5000-65352. National Renewable Energy Laboratory (NREL), Golden, CO (US). http://www.nrel.gov/docs/fy16osti/65352.pdf

sPower. (2016). “sPower Latigo Wind Park Commissioned, Generating Clean Energy.” Accessed September 19, 2016. http://www.spower.com/news_2016/news-2016-03-11.php

Sprague, James. 2017. "Legislative Committee to Study Wind.” Connersville News Examiner, July 14. http://www.newsexaminer.com/news/legislative-committee-to-studywind/article_03989709-5235-523e-9eda-ff76b4a6f5c2.html 
Srubas, Paul. 2014. "Health Officials Weigh Next Step in Wind Turbine Battle.” Green Bay Press-Gazette, October 26.

http://www.greenbaypressgazette.com/story/news/local/2014/10/26/health-officials-weigh-nextstep-wind-turbine-battle/17967875/

State of Delaware Public Service Commission. 2011. In the Matter of the Application of Delmarva Power and Light Company for Approval of PSC Docket No. 11-362 Qualified Fuel Cell Provider Project Tariffs. http://depsc.delaware.gov/orders/8079.pdf

SunEdison. 2015. "Columbia, Md. Now 100 Percent Renewable with Latest Solar Farm from SunEdison.” PR Newswire. http://www.prnewswire.com/news-releases/columbia-md-now-100percent-renewable-with-latest-solar-farm-from-sunedison-300141481.html

SunZia Southwest Transmission Project. “Project Description.” Accessed July 13, 2016. http://www.sunzia.net/project_information.php

Teague, Michael. 2015. "Fossil-Fuel-Rich Oklahoma Digs into Wind Energy.” North American Windpower, January. http://nawindpower.com/online/issues/NAW1501/FEAT_03_Fossil-FuelRich-Oklahoma-Digs-Into-Wind-Energy.html

Texas A\&M Engineering Experiment Station. 2016. “Press Release: Louisiana wind developer announces 150-MW sustainable energy project in Evangeline Parish.”Accessed October 22, 2016.

http://www.publicnow.com/view/2652F051A421488C80B29C2B43B75E753EE48D64?201605-20-22:00:51+01:00-xxx5819

TransWest Express. Accessed December 2, 2017. http://www.transwestexpress.net/index.shtml

TransWest Express. 2017. "USFS Issues Its Record of Decision for the TWE Project.” http://www.transwestexpress.net/news/alerts/2017/053117-usfs-record-of-decision.shtml

Uhlenhuth, Karen. 2016a. "Group Challenges Missouri Utilities on Renewable Standard Compliance.” Midwest Energy News, June 28.

http://midwestenergynews.com/2016/06/28/group-challenges-missouri-utilities-on-renewablestandard-compliance/

Uhlenhuth, Karen. 2016b. "Small Utilities More Likely to Seek Out Renewables after FERC Ruling.” Midwest Energy News, July 5. http://midwestenergynews.com/2016/07/05/smallutilities-more-likely-to-seek-out-renewables-after-ferc-ruling/

Uhlenhuth, Karen. 2017. "End of State Tax Credit Expected to Impact Iowa Clean Energy Growth.” Midwest Energy News, May 4. http://midwestenergynews.com/2017/05/04/end-ofstate-tax-credit-expected-to-impact-iowa-clean-energy-growth/

U.S. Bureau of Land Management. 2016a. Executive Summary for the Record of Decision: Desert Renewable Energy Conservation Plan. Accessed March 20, 2018. http://www.drecp.org/finaldrecp/rod/DRECP_BLM_LUPA_ROD.pdf 
U.S. Bureau of Land Management. 2016b. NEPA Hot Sheet Spring 2016: BLM Wyoming Land Use Plans and Proposed Projects. Accessed October 22, 2016.

http://www.blm.gov/style/medialib/blm/wy/information/NEPA.Par.94494.File.dat/hot_sheet.pdf

U.S. Department of Energy. 2015a. Alaska Climate Change and the U.S. Energy Sector:

Regional Vulnerabilities and Resilience Solutions.

https://energy.gov/sites/prod/files/2015/10/f27/Alaska.pdf

U.S. Department of Energy. 2015b. Enabling Wind Power Nationwide. DOE/EE-1218.

http://energy.gov/sites/prod/files/2015/05/f22/Enabling\%20Wind\%20Power\%20Nationwide_18 MAY2015_FINAL.pdf

U.S. Department of Energy. 2015c. Hawaii and Puerto Rico Climate Change and the U.S. Energy Sector: Regional Vulnerabilities and Resilience Solutions. https://energy.gov/sites/prod/files/2015/10/f27/Hawaii_and_Puerto_Rico.pdf

U.S. Department of Energy. 2015d. Hawai'i Clean Energy Final Programmatic Environmental Impact Statement Summary. DOE/EIS-0459.http://energy.hawaii.gov/wpcontent/uploads/2015/09/Final-PEIS-Summary_Sept2015.pdf

U.S. Department of Energy. 2015e. Wind Vision: A New Era for Wind Power in the United States. DOE/GO-102015-4557. http://energy.gov/eere/wind/wind-vision

U.S. Department of Energy. 2017a. 2016 Distributed Wind Market Report. PNNL-26540. Pacific Northwest National Laboratory (PNNL), Richland, WA (US).

https://energy.gov/sites/prod/files/2017/08/f35/2016-Distributed-Wind-Market-Report.pdf

U.S. Department of Energy. 2017b. 2016 Offshore Wind Technologies Market Report. DOE/GO-102017-5031. https://energy.gov/sites/prod/files/2017/08/f35/2016\%20Offshore\%20Wind\%20Technologies\%2 0Market\%20Report.pdf

U.S. Department of Energy. 2017c. 2016 Wind Technologies Market Report. DOE/GO-1029175033. https://energy.gov/eere/wind/downloads/2016-wind-technologies-market-report

U.S. Department of the Interior. 2015. Historic Conservation Campaign Protects Greater Sage Grouse. Accessed September 24, 2016. https://www.doi.gov/pressreleases/historic-conservationcampaign-protects-greater-sage-grouse

U.S. Department of the Interior. 2016. Secretary Jewell, State of California Announce Landmark Renewable Energy, Conservation Plan for 10 Million Acres of California Desert. Accessed August 25, 2017. https://www.doi.gov/pressreleases/secretary-jewell-state-california-announcelandmark-renewable-energy-conservation-plan

U.S. Energy Information Association. 2017a. Electricity Data Browser. https://www.eia.gov/electricity/data/browser/. Accessed August 21, 2017. 
U.S. Energy Information Association. 2017b. West Virginia State Profile and Energy Estimates. http://www.eia.gov/state/?sid=WV. Last modified July 20, 2017.

Van Dam, C.P. “California Offshore Wind Energy: A Personal Vision.” BOEM Offshore Renewable Energy Workshop, July 29-30, 2014.

Walton, Robert. 2016. "Maryland Gov. Hogan Vetoes Increase to State's Renewable Energy Standard.” Utility Dive. May 31. http://www.utilitydive.com/news/maryland-gov-hogan-vetoesincrease-to-states-renewable-energy-standard/420034/

Welch, Kevin. 2016. “Wind Energy Boom Spurs \$77.4 Million Expansion.” Amarillo Globe News, March 4. http://amarillo.com/news/latest-news/2016-03-03/wind-energy-boom-spurs774m-expansion

Wheeler, Timothy B. 2015. "Shore Wind Project Scrapped amid Political Roadblocks." Baltimore Sun, April 6. http://www.baltimoresun.com/features/green/blog/bs-md-wind-energyhurdles-20150406-story.html

WINDExchange. (2017). Installed and Potential Wind Power Capacity and Generation. U.S. Department of Energy. Accessed August 26, 2017. https://windexchange.energy.gov/maps$\underline{\text { data } / 321}$

WPPI Energy. “WPPI Energy Seeks Additional Renewables.” Accessed October 22, 2016. https://wppienergy.org/News/NewsItem?item=42

WPPI Energy. "WPPI Energy to Purchase Output from Bishop Hill III Wind Energy Center." Accessed November 5, 2017. https://wppienergy.org/News/NewsItem?item=50

Xcel Energy. Rush Creek Wind Project. Accessed July 13, 2016.

https://www.xcelenergy.com/company/rates_\&_regulations/filings/rush_creek_wind_project

Zak, Annie. 2017. “Alaska Railbelt Utilities Announce Power-Pooling Agreement.” Anchorage Daily News, January 30. https://www.adn.com/business-economy/2017/01/30/alaska-railbeltutilities-announce-power-pooling-agreement

Zuckerman, Jake. 2017. "West Virginia Senate Votes to Repeal Wind Turbine Tax Cut.” Charleston Gazette Mail, March 18. http://www.wvgazettemail.com/newspolitics/20170318/wv-senate-votes-to-repeal-wind-turbine-tax-cut

Zullo, Robert. 2017. "Long-Anticipated Dominion Wind Project off Virginia Beach Will Move Forward.” Richmond Times-Dispatch, July 10. http://www.richmond.com/news/virginia/longanticipated-dominion-wind-project-off-virginia-beach-will-move/article_33053a0c-3dd6-5fecb71c-a89424d0d948.html 


\section{ONREL}

National Renewable Energy Laboratory 15013 Denver West Parkway

Golden, CO 80401

303-275-3000 • www.nrel.gov

NREL is a national laboratory of the U.S. Department of Energy Office of Energy Efficiency and Renewable Energy Operated by the Alliance for Sustainable Energy, LLC

NREL/TP-5000-70738 • April 2018

Top left: Big Horn Wind Farm in Washington. Photo from Iberdrola Renewables, Inc., NREL 15194

Top right: NorthWind 100 turbine in Toksook Bay, Alaska.

Photo from Northern Power Systems, NREL 14406

Mid left: Saddleback Ridge Wind Project in Maine.

Photo from Ken Boulier, Patriot Renewables, NREL 40575

Bottom left: Peak View Wind Project in Colorado.

Photo from Black Hills Energy, NREL 41784

Bottom right: Rolling Hills Wind Farm in lowa.

Photo by Dennis Schroeder, NREL 47315 